\title{
Managing America's Solid Waste
}

J.A. Phillips

J.A. Phillips \& Associates

Boulder, Colorado

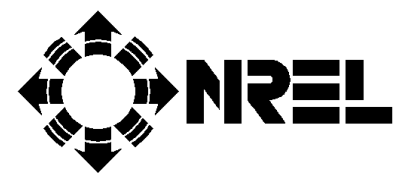

National Renewable Energy Laboratory 1617 Cole Boulevard

Golden, Colorado 80401-3393

A national laboratory of the U.S. Department of Energy Managed by Midwest Research Institute for the U.S. Department of Energy under contract No. DE-AC36-83CH10093 


\section{Managing America's Solid Waste}

J.A. Phillips

J.A. Phillips \& Associates

Boulder, Colorado

NREL Technical Monitor: Carlton Wiles

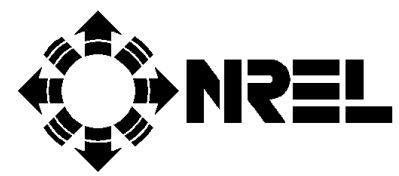

National Renewable Energy Laboratory 1617 Cole Boulevard

Golden, Colorado 80401-3393

A national laboratory of the U.S. Department of Energy Managed by Midwest Research Institute for the U.S. Department of Energy under contract No. DE-AC36-83CH10093

Prepared under Subcontract No. AAE-5-14269

September 1998 
This publication was reproduced from the best available copy Submitted by the subcontractor and received no editorial review at NREL

\section{NOTICE}

This report was prepared as an account of work sponsored by an agency of the United States government. Neither the United States government nor any agency thereof, nor any of their employees, makes any warranty, express or implied, or assumes any legal liability or responsibility for the accuracy, completeness, or usefulness of any information, apparatus, product, or process disclosed, or represents that its use would not infringe privately owned rights. Reference herein to any specific commercial product, process, or service by trade name, trademark, manufacturer, or otherwise does not necessarily constitute or imply its endorsement, recommendation, or favoring by the United States government or any agency thereof. The views and opinions of authors expressed herein do not necessarily state or reflect those of the United States government or any agency thereof.

Available to DOE and DOE contractors from:

Office of Scientific and Technical Information (OSTI)

P.O. Box 62

Oak Ridge, TN 37831

Prices available by calling (423) 576-8401

Available to the public from:

National Technical Information Service (NTIS)

U.S. Department of Commerce

5285 Port Royal Road

Springfield, VA 22161

(703) $605-6000$ or (800) 553-6847

or

DOE Information Bridge

http://www.doe.gov/bridge/home.html 


\section{Contents}

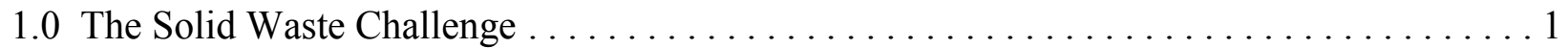

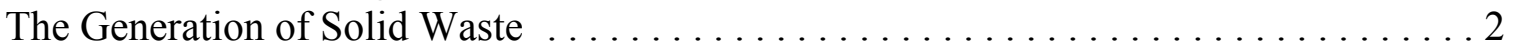

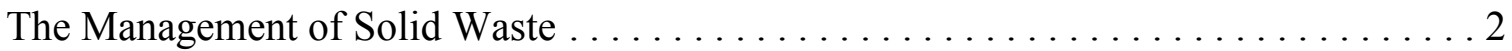

Role of Local Governments . . . . . . . . . . . . . . . . . . . . . . . 3

Regional Waste Management $\ldots \ldots \ldots \ldots \ldots \ldots \ldots \ldots \ldots \ldots \ldots$

Role of States . . . . . . . . . . . . . . . . . . . . . 4

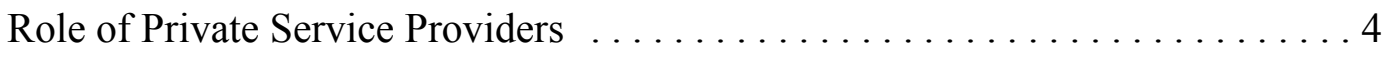

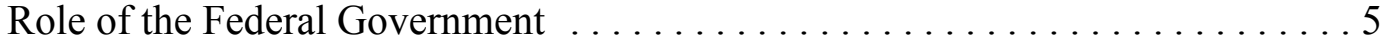

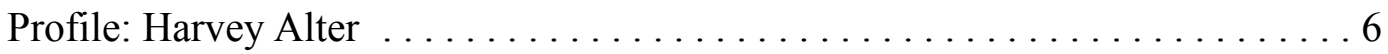

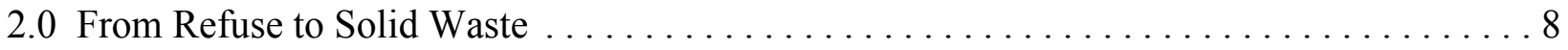

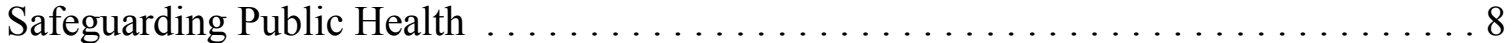

Early History of Sanitation in the United States $\ldots \ldots \ldots \ldots \ldots \ldots \ldots$

Early Twentieth-Century Solid Waste Management . . . . . . . . . . . . 10

The Origin of Modern Municipal Solid Waste Management . . . . . . . . . . 11

Recent Changes in Solid Waste Management . . . . . . . . . . . . . . . . 12

Changes in Waste Composition . . . . . . . . . . . . . . . 13

Changes in Collection and Hauling $\ldots \ldots \ldots \ldots \ldots \ldots \ldots \ldots$

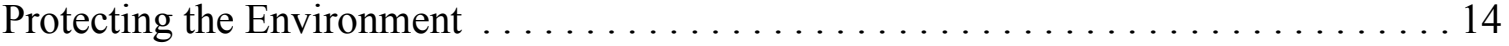

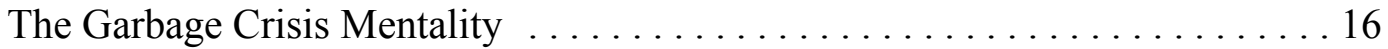

Solid Waste Management and Climate Change $\ldots \ldots \ldots \ldots \ldots \ldots . \ldots \ldots$

Wisely Managing Material and Energy Resources $\ldots \ldots \ldots \ldots \ldots \ldots \ldots \ldots$

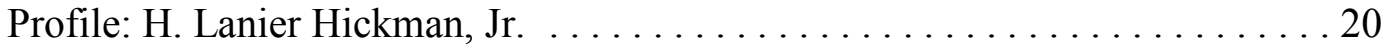

3.0 The Federal Role in Solid Waste Management $\ldots \ldots \ldots \ldots \ldots \ldots \ldots \ldots \ldots \ldots \ldots$

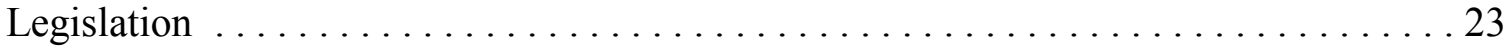

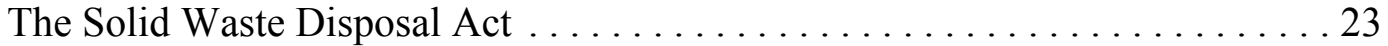

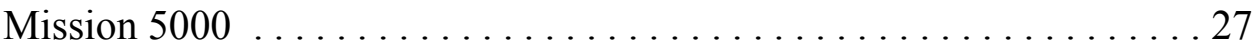

New Professionalism . . . . . . . . . . . . . . . . . 27

Grants to Improve Solid Waste Management . . . . . . . . . . . . . . . 28

The Scientific Advisory Council and NEPA . . . . . . . . . . . . . 28

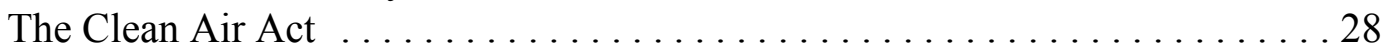

The Resource Recovery Act . . . . . . . . . . . . . . . . . . . . . . . 29

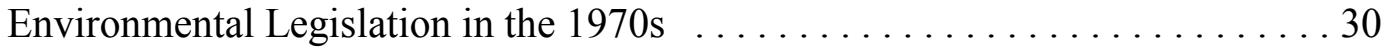

The Resource Conservation and Recovery Act . . . . . . . . . . . . . 30

The Need for a National Solid Waste Policy . . . . . . . . . . . . 32

Hazardous and Solid Waste Amendments to RCRA . . . . . . . . . 33

Attempts to Reauthorize RCRA . . . . . . . . . . . . . 33

Laws Promoting Energy Recovery . . . . . . . . . . . . . . . . . . 34

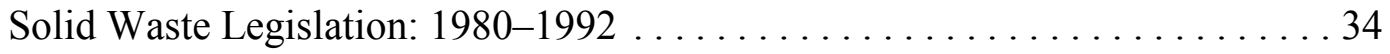

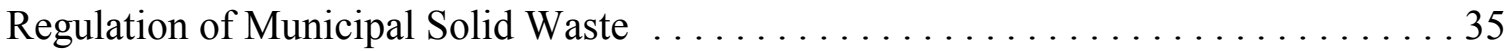

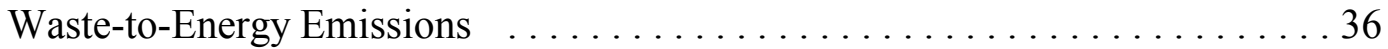

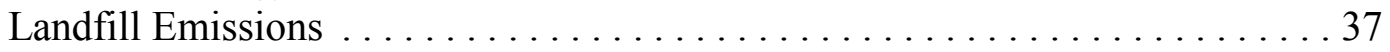




\section{Contents (Continued)}

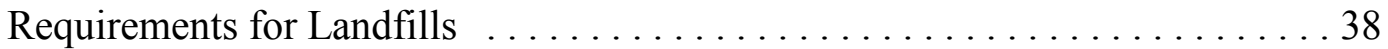

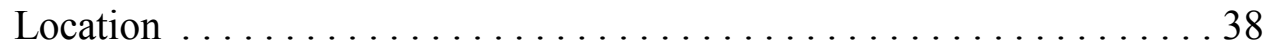

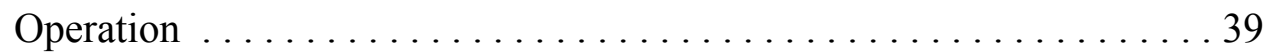

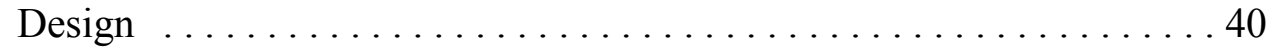

Groundwater Monitoring and Protection . . . . . . . . . . . . . . 40

Closure and Post-Closure Care . . . . . . . . . . . . . . . . 40

Financial Assurance ....................... 41

Clean Water Regulations ............................... 41

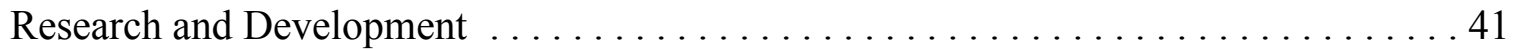

Agencies Responsible for Municipal Solid Waste Programs . . . . . . . . . . . 42

U.S. Public Health Service . . . . . . . . . . . . . . . . . . . . . . . 42

Tennessee Valley Authority . . . . . . . . . . . . . . . . . . . . . . . . . . . . 42

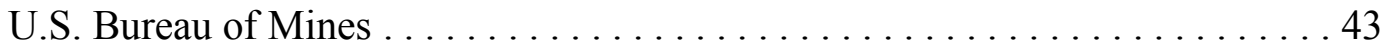

National Institute of Standards and Technology $\ldots \ldots \ldots \ldots \ldots \ldots \ldots \ldots$

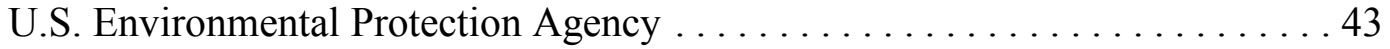

Energy Research and Development Administration

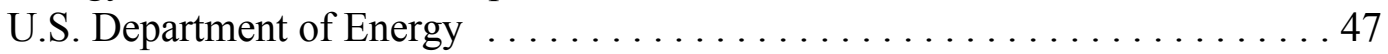

Argonne National Laboratory $\ldots \ldots \ldots \ldots \ldots \ldots \ldots \ldots \ldots . \ldots \ldots$

National Renewable Energy Laboratory $\ldots . \ldots \ldots \ldots . \ldots . \ldots . \ldots . \ldots 49$

Profile: Donald K. Walter . . . . . . . . . . . . . . . . . . . . . 49

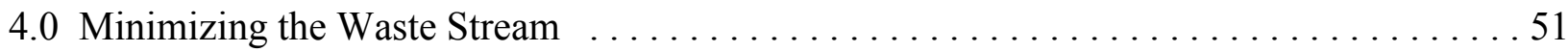

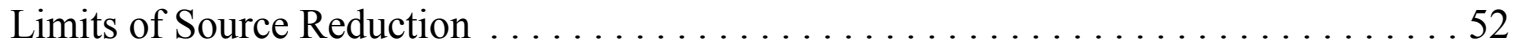

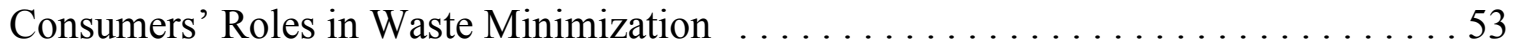

Keeping Toxic Waste out of Municipal Solid Waste $\ldots \ldots \ldots \ldots \ldots \ldots \ldots \ldots 4$

Industry's Role in Waste Minimization . . . . . . . . . . . . . . . . . 55

State and Federal Initiatives to Reduce Solid Waste $\ldots \ldots \ldots \ldots \ldots \ldots \ldots \ldots$

Profile: Steve Levy . . . . . . . . . . . . . . . . . . . 57

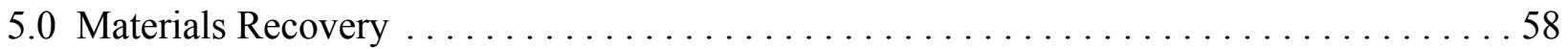

The Federal Role in Recycling . . . . . . . . . . . . . . . . . . . . . . . 60

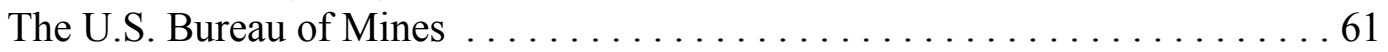

The U.S. Environmental Protection Agency $\ldots \ldots \ldots \ldots \ldots \ldots \ldots . \ldots \ldots 6$

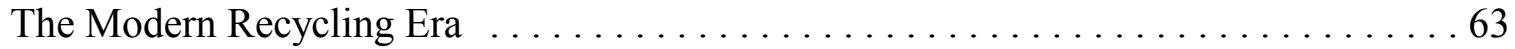

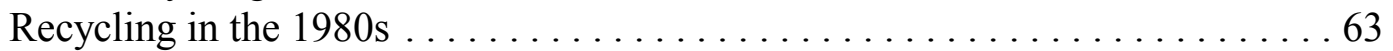

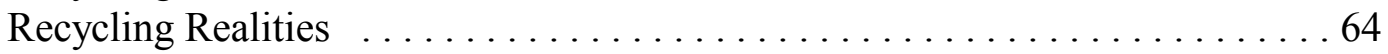

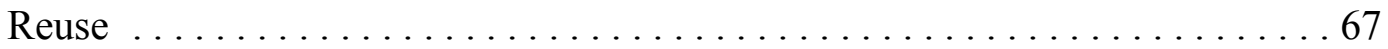

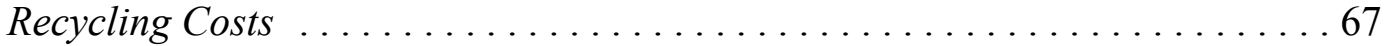

The Environmental Impact of Recycling . . . . . . . . . . . . . 68

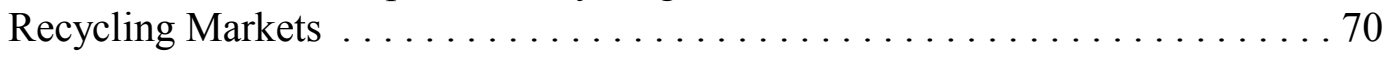

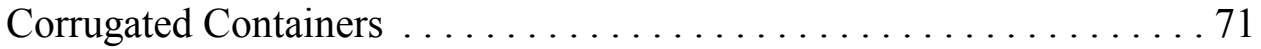

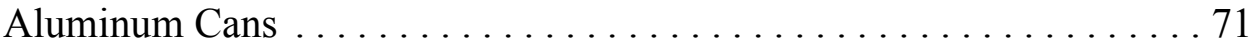

Steel ............................. 71 


\section{Contents (Continued)}

Plastics ............................. 71

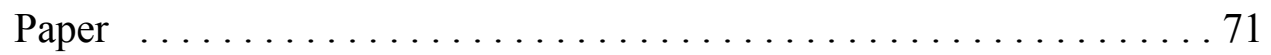

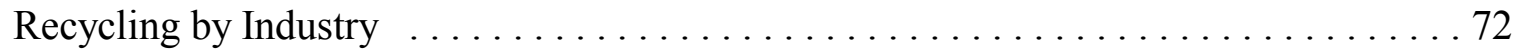

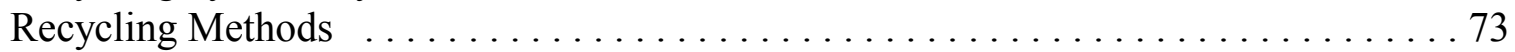

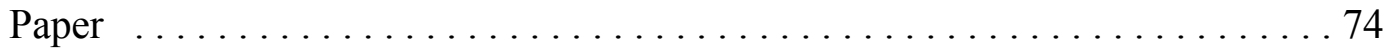

Boxboard ............................... 74

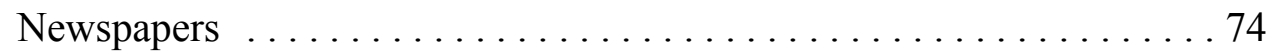

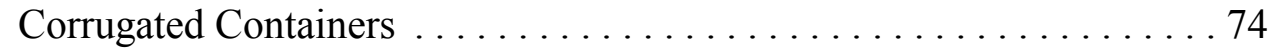

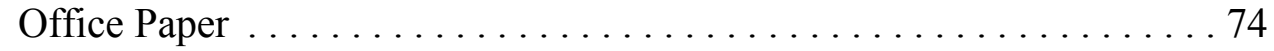

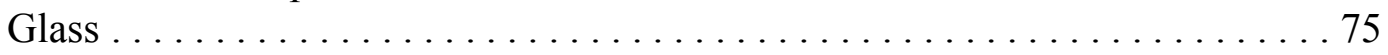

Aluminum and Nonferrous Metals $\ldots \ldots \ldots \ldots \ldots \ldots \ldots \ldots \ldots$

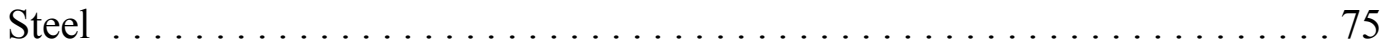

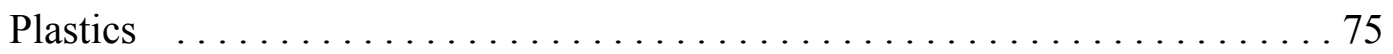

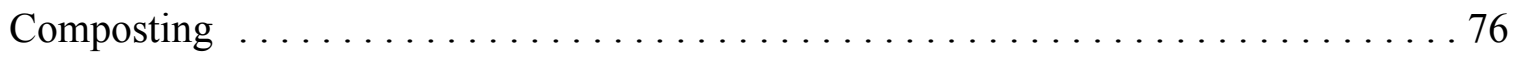

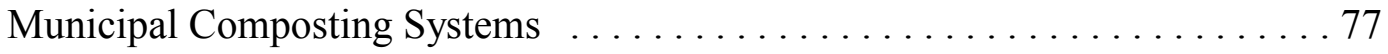

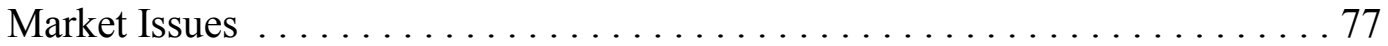

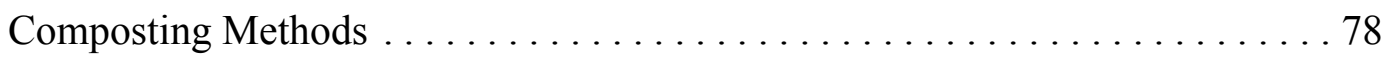

Mixed-Waste Systems . . . . . . . . . . . . . . . . . . . 78

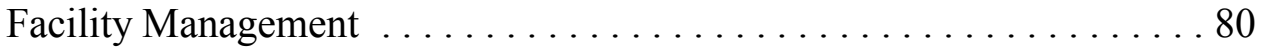

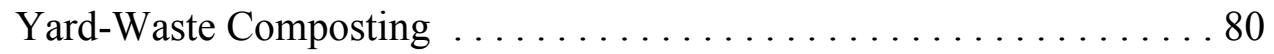

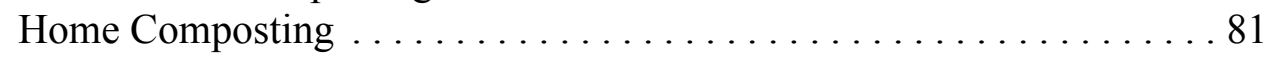

Profile: George Trezak . . . . . . . . . . . . . . . . . 81

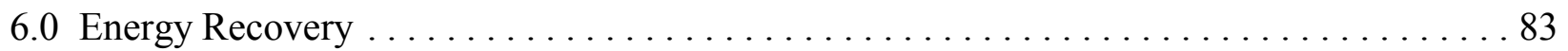

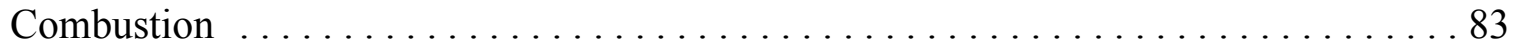

The Waste-to-Energy Industry: $1970-1979 \ldots \ldots \ldots \ldots \ldots$. . . . . . . . . 87

Chicago's Northwest Garbage Incinerator . . . . . . . . . . . . . . 87

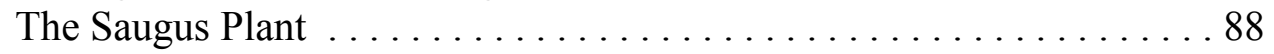

The Waste-to-Energy Industry: $1980-1989 \ldots \ldots \ldots \ldots \ldots \ldots$. . . . . . . . . 91

The Waste-to-Energy Industry: $1990-1995$. . . . . . . . . . . . . . . . . . . . 94

The Federal Program . . . . . . . . . . . . . . . . . . . . . . . 96

Pyrolysis Research . . . . . . . . . . . . . . . . . . . 99

RDF Technology Development . . . . . . . . . . . . . . 100

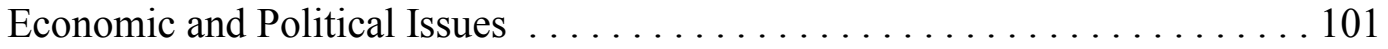

Costs ............................... 101

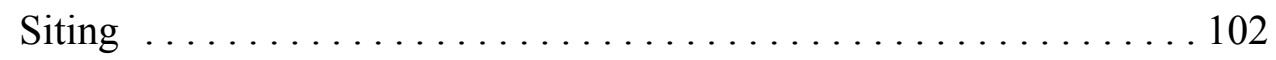

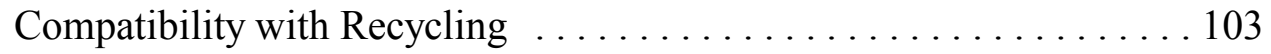

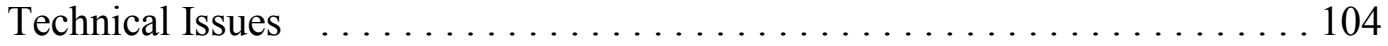

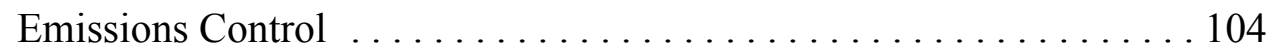

Ash ................................... 106

Waste Combustion Methods . . . . . . . . . . . . . . . . . . . . . 107

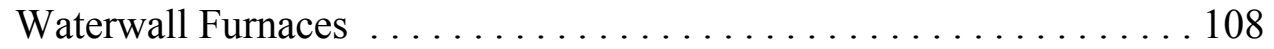

Modular Combustion Units . . . . . . . . . . . . . . . . 108 


\section{Contents (Continued)}

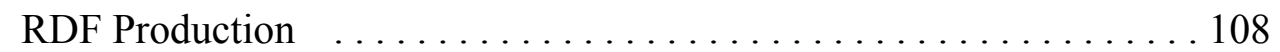

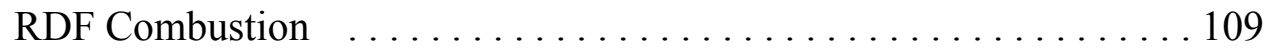

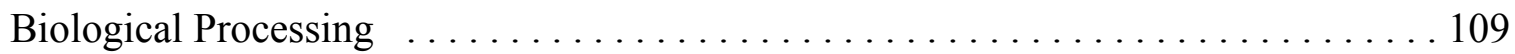

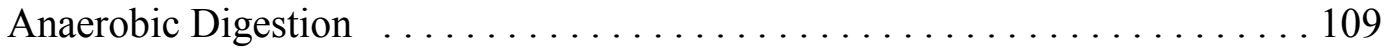

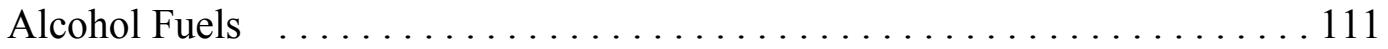

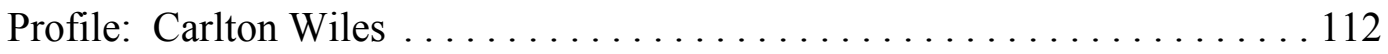

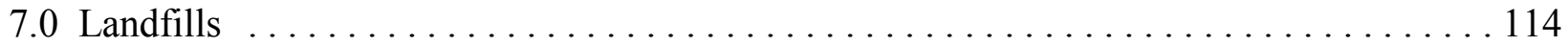

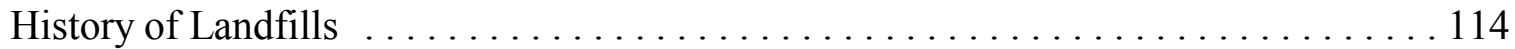

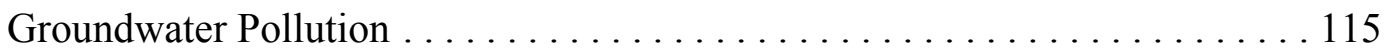

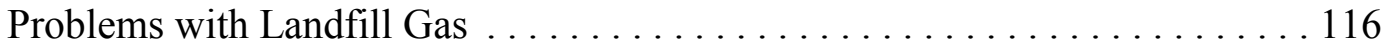

Problems with Landfill Settlement $\ldots \ldots \ldots \ldots \ldots \ldots \ldots \ldots \ldots \ldots \ldots$

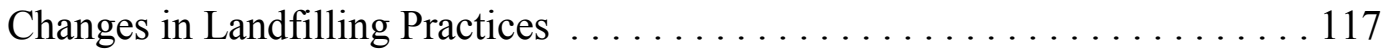

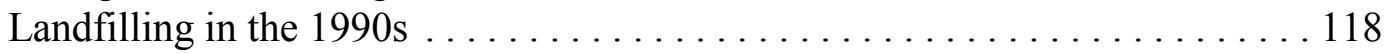

Waste Processing inside Landfills ............................... 119

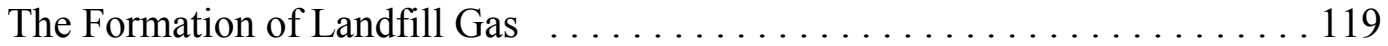

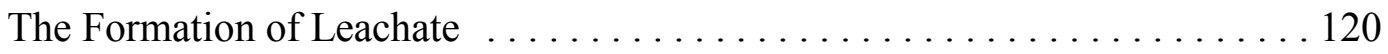

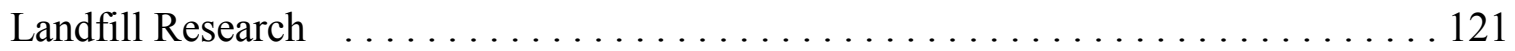

Energy Recovery from Landfill Gas $\ldots \ldots \ldots \ldots \ldots \ldots \ldots \ldots \ldots \ldots . \ldots \ldots \ldots$

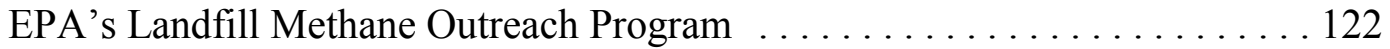

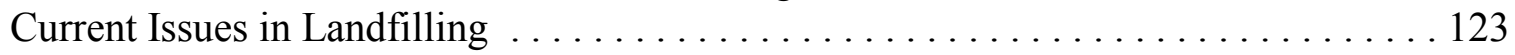

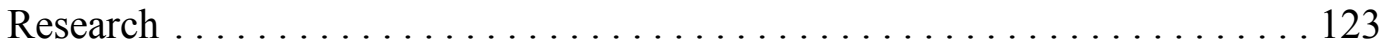

Landfill Reuse ..................................... 124

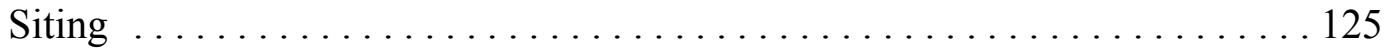

Air Emissions . . . . . . . . . . . . . . . . . . . . . . . . 125

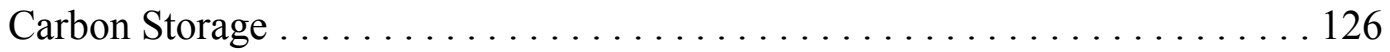

Landfill Stewardship by Future Generations $\ldots \ldots \ldots \ldots \ldots \ldots \ldots \ldots \ldots$

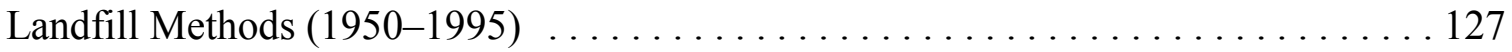

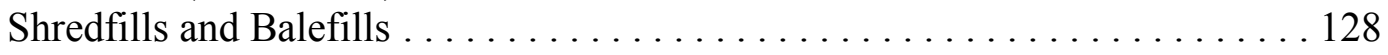

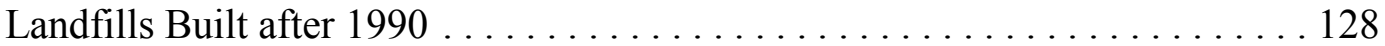

Liner Systems . . . . . . . . . . . . . . . . . . . . . . . 129

Systems for Collecting and Treating Leachate .............. 129

Systems for Monitoring Groundwater $\ldots \ldots \ldots \ldots \ldots \ldots \ldots \ldots$

Daily and Permanent Covers ........................ 130

Systems for Monitoring and Collecting Landfill Gas .......... 130

Systems for Recovering Energy . . . . . . . . . . . . . . . . 132

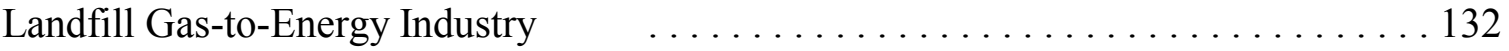

8.0 Waste Management Today . . . . . . . . . . . . . . . . . . . . . . . . . . . 134

Integrated Waste Management ................................. 135

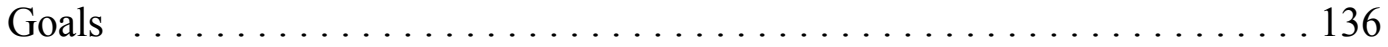

Linking Recycling and Waste Combustion $\ldots \ldots \ldots \ldots \ldots \ldots \ldots \ldots \ldots$ 


\section{Contents (Concluded)}

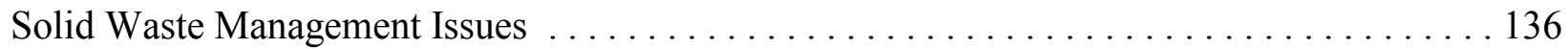

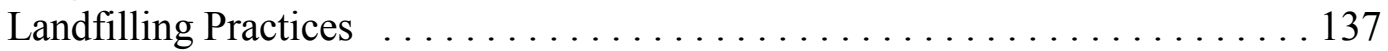

Flow Control . . . . . . . . . . . . . . . . . . . . . . . . . . 139

Who Will Control Tomorrow's Solid Waste? . . . . . . . . . . . . . . . . . . 141

The Future of Federal Regulation . . . . . . . . . . . . . . . . . . . . 142

The Need for Research and Development . . . . . . . . . . . . . . . . . . . 144

Federal Technology Research Projects . . . . . . . . . . . . . . . . 146

Integrated Waste Management Case Studies . . . . . . . . . . . . 146

Materials Recovery Facilities . . . . . . . . . . . . . . . . 146

Comprehensive Model of Integrated Solid Waste Management . . . . . 147

Argonne Studies . . . . . . . . . . . . . . . . . . . . . . . 148

Research Projects Requested by Industry . . . . . . . . . . . . . . . . . 148

The Benefits of a Federal Role in Solid Waste Management . . . . . . . . . 150

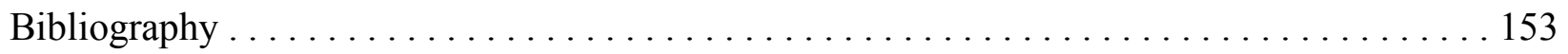

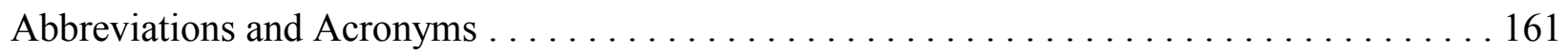

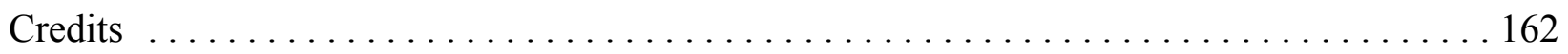




\section{Preface}

In 1992, Helena Chum asked me to interview Don Walter and record his recollections of the more than 20 years he spent with the municipal solid waste (MSW) program at the Energy Research and Development Administration and the U.S. Department of Energy. Don was getting ready to retire, and Helena wanted a record of his experience and accumulated wisdom. Don's recollections, which he graciously shared with me and Rick Piltz, provided the foundation for much of this manuscript. Shortly after Rick and I began talking to Don, however, the project was put on hold for nearly 2 years. The project resumed in 1994 with a new charge: to create an historical overview of the federal role in MSW from 1965 to approximately 1995. The new direction came in response to decisions to eliminate MSW programs at the U.S. Department of Energy and the U.S. Environmental Protection Agency. It was hoped that this report would provide important background for future MSW research and development initiatives.

As part of our assignment to create a more comprehensive record of what happened between 1965 and 1995, Rick Piltz and I interviewed dozens of key participants in the federal program and in the solid waste industry. In the process, we encountered a number of professionals who had spent the better part of their careers in MSW management. Many provided us with multiple interviews over periods of several months. We selected six of them who had dedicated most of their professional lives to improving MSW management to profile as part of this report. The profiles, one of which is contained in each of the first six chapters, were of Harvey Alter, H. Lanier (Lanny) Hickman, Don Walter, Steve Levy, George Trezak, and Carlton Wiles. Our heartfelt thanks to them and the many other professionals who shared their experiences with us, as well as to those who helped us review and refine the manuscript. In particular, we would like to thank N.C. Vasuki, chief executive officer of Delaware's Solid Waste Authority; Maria Zannes of the Integrated Waste Services Association; Don Walter, now retired; Simon Friedrich of the U.S. Department of Energy; and Philip Shepherd and Carlton Wiles of the National Renewable Energy Laboratory for their insightful and thoughtful comments on the manuscript. Finally, thanks to Helena Chum for the vision that got the project rolling.

Julie Phillips

Boulder, Colorado 


\subsection{The Solid Waste Challenge}

The most amazing feature of the garbage crisis of the 1990s is that it is the direct result of environmental progress in waste disposal technology. ${ }^{1}$

On average, every American throws away more than 2 pounds of solid waste each day. ${ }^{2}$ Americans use and then discard glass containers, paper and plastic packaging, newspapers, broken toys, food scraps, steel cans, grass clippings, old televisions, worn-out appliances, office paper, textiles, cardboard boxes, tires, paper plates, plastic spoons, disposable diapers, aluminum cans, and more.

No one knows for sure how much solid waste Americans produce each year, because no one has systematically studied solid waste generation in the United States. Using information about the number of products manufactured and sold, the U.S. Environmental Protection Agency (EPA) estimated that the United States produced 207 million tons of solid waste in 1993. When BioCycle magazine asked each state for information about the total amount of waste put in landfills or recycled in 1993, it discovered that the amount of waste managed as municipal solid waste (MSW) totaled 307 million tons! MSW includes not only residential solid waste but also a variety of nonhazardous discards from commercial, institutional, and industrial sources.

The difference in the two estimates may be due to the almost 100 million tons of industrial, agricultural, and construction wastes that do not qualify as MSW, but get thrown away in MSW landfills anyway. Remarkably, total solid waste generation may have been even higher than either estimate. Many companies managed their nonhazardous waste on site, and the waste was not counted in either BioCycle's or EPA's estimate.

Curiously, most Americans do not worry very much about solid waste. They simply fill up their trash cans and recycling bins, and set them out for the local garbage collector. ${ }^{3}$ As long as the collection trucks arrive on schedule, solid waste management remains essentially out of sight and out of mind.

Nevertheless, local governments and private service providers must manage enormous quantities of solid waste. A small city with 100,000 people handles more than 1,100 tons of residential solid waste every week. A metropolitan area with one million inhabitants has to manage more than 11,000 tons of residential solid waste in a week. Throughout the nation, waste management professionals handle more than 3 million tons of residential solid waste every week.

The good news is that solid waste is now managed responsibly most of the time. Thanks to government regulation, improved technology, and better methods, solid waste management professionals routinely safeguard the public's health and prevent pollution. Solid waste management no longer includes incinerators without emissions controls, ocean dumping, or open dumps teeming

\footnotetext{
${ }^{1}$ Alexander, Judd H. (1993). In Defense of Garbage. Westport, Connecticut, and London: Praeger, p. 7.

2 If residential and commercial solid waste are both taken into account, per capita solid waste generation is nearly four and a half pounds per day. Residential solid waste accounts for slightly less than half the total.

${ }^{3}$ An observant citizen might notice that the amount of trash in the alley or on the curb varies with the time of year. People set out less trash in February. The amount of solid waste rises to a peak in May, then falls off and remains constant through the summer. It goes way up in October, coinciding with the fall cleanup of yard waste, and then levels off until mid-December, when it skyrockets for about 2 weeks around the holiday season.
} 
with vermin and toxic chemicals leaching into nearby wells and rivers. Today's solid waste management systems work far better than those Americans relied upon in 1960.

Even so, there are still problems to be solved in solid waste management. Litter remains a chronic problem; some older landfills continue to threaten the quality of groundwater; landfills discharge an as-yet-undetermined amount of methane (a potent greenhouse gas) into the atmosphere; and the environmental effects of recycling have yet to be fully measured. And we still need to study the economics of solid waste management, one of the most challenging public works services.

\section{The Generation of Solid Waste}

The amount of solid waste produced each year in the United States has either doubled or tripled from 88 million tons in 1960 to between 207 and 307 million tons in 1993, depending on which estimate you believe. However, there are virtually no data regarding MSW generation in 1960 and only incomplete data for 1993. The figure 88 million tons is, at best, an educated guess based on some limited information on industrial production at the time. The 1993 estimates are based on better information, but the newer estimates are still educated guesses, not exact measurements. Guessing is the best we can do until it becomes a priority to gather adequate information regarding the amounts and kinds of wastes Americans produce and manage as solid waste.

There are several reasons for increased solid waste generation in the United States. To begin with, there are 80 million more Americans today than there were in 1960. In addition, we use more paper and plastic packaging than ever before. The use of office paper has mushroomed in the wake of computers and copy machines. Disposable items (such as diapers, paper plates, razors, paperback books, and magazines) are increasingly popular. And when people have more money to spend (as they did from 1960 through 1976, for instance), they often create more solid waste.

Taken together, these factors have fueled a steady increase in the amount of solid waste generated. Per capita MSW generation has grown from about 2.7 pounds per day in 1960 to today's record 4.4 pounds per day, according to EPA estimates. But, there is a bright spot in this picture: per capita waste generation is now holding steady; by 2000, it may even fall slightly. Waste generation is finally leveling off because efforts to minimize waste and encourage recycling may have stopped the upward spiral. However, actually reducing the amount of solid waste Americans create each year remains an elusive goal.

\section{The Management of Solid Waste}

Solid waste management has changed in important ways in the past 30 years. Across the nation, modern, well-designed landfills and waste-to-energy plants have replaced open dumps and polluting incinerators. Recycling has become an integral part of solid waste management in most communities. The nation as a whole is committed to safer, more environmentally responsible management of solid waste.

Even though recycling is an expensive alternative to traditional solid waste management methods, more than $40 \%$ of Americans now have access to curbside collection programs for recyclable materials. Recycling's supporters include solid waste management professionals, industry, universities, politicians, and ordinary people from all walks of life. Recycling is an important component of resource recovery, which includes the recovery of energy and materials from solid waste. Since 1970, an emphasis on resource recovery has helped people to see their waste as a resource for materials and energy. As a result, leaders from the public and private sectors have begun to think about making waste management planning part of manufacturing, transportation, and other segments of the economy. 
In the past, public works managers simply scrambled to dispose of solid waste as it appeared. Because there was no mechanism to help people make the connection between the production of goods and services and waste, there was no easy solution for the solid waste problem once it got out of control. Instead, the nation has had to resort to punitive measures designed to remedy years of environmental neglect.

State agencies, local governments, and private companies have all played roles in improving America's solid waste management. Since 1963, the federal government has worked with both the public and private sectors to improve solid waste management standards, while leaving implementation of those standards to local governments.

\section{Role of Local Governments}

Local governments collect and manage solid waste as part of their responsibility for protecting human health. There is no single system for accomplishing these tasks. The composition and amount of solid waste vary from community to community. The amount of landfill space available, capacity for waste combustion, support for recycling and composting, public attitudes, financial constraints, and regulations also vary from region to region. All local solid waste management systems consist of the same basic elements: collection, hauling, recycling, combustion, and landfilling. Waste management also includes planning.

Local governments handle solid waste collection in three basic ways: Some use municipal employees to collect solid waste and transport it to a materials recovery facility, waste-to-energy plant or landfill; others contract with private companies for solid waste collection and transport; and the remainder rely on private haulers to serve customers directly. On average, about $65 \%$ of the cost of solid waste management goes for collection and transport.

There are advantages and disadvantages to using municipal staff to collect solid waste. Municipalities are exempt from paying taxes and are not required to earn a profit. These factors can provide an economic advantage to a municipal agency over a private contractor. There are some disadvantages as well. For example, municipally operated waste services may be expensive for small communities, particularly if they lack access to a nearby landfill or materials recovery facility. The majority of the nation's cities and towns now contract with private service providers to collect their solid waste.

Many local governments work on creating economic incentives for reducing solid waste. These communities have adopted a unit pricing system - charges are based upon the amount of solid waste set out for collection and disposal. Some cities do not charge for items set out for recycling; others charge proportionally for these services as well.

Once solid waste is collected, local governments may choose to operate one or more of the following: a landfill, a composting facility, a recycling program, or a waste-to-energy plant. Or they may contract for such services with private companies. Regardless of which methods are used, local governments are responsible for ensuring that waste is collected, stored, and managed in a manner that is both safe and sanitary. Local governments often work with state and federal agencies in solid waste planning.

\section{Regional Waste Management}

Many communities have four things in common: growing population, increasing amounts of solid waste, rising costs, and a mandate to meet stringent federal and state standards for waste combustion and landfilling. As a result, local governments have begun to work together to develop regional strategies for managing solid waste. Such strategies include the creation of large, regional 
landfills; the building of materials recovery facilities that accept waste from an entire county; or the operation of a waste-to-energy facility that serves a large metropolitan area and surrounding communities. Other collaborative efforts include marketing recovered materials, working to attract new regional remanufacturing facilities, and purchasing large volumes of recycled products. Such endeavors allow municipalities to share resources and more equitably distribute costs.

\section{Role of States}

During the past 30 years, state governments have regulated solid waste management. They have responded to federal solid waste initiatives by creating state solid waste agencies, developing state-wide solid waste management plans, and enacting laws to regulate local solid waste management practices. State laws often encourage local governments to implement waste reduction, recycling, and one or more specific disposal methods. State solid waste regulations tend to be more encompassing than federal regulations.

States are responsible for ensuring that federal solid waste regulations are enforced. For the most part, states develop solid waste policies but leave their implementation to local governments. Some states provide technical assistance to local governments in creating and implementing solid waste plans.

A few state solid waste agencies actively encourage recycling market development. Incentives, such as tax credits, low-interest loans, and grants, exist in a few locations to help stabilize and strengthen markets. Other states have implemented strategies for purchasing recycled materials. Many states have also enacted regulations for landfills and waste-to-energy facilities.

\section{Role of Private Service Providers}

Private companies have assumed a significant role in the collection and management of solid waste. The private solid waste industry expanded during the 1980s when federal, state, and local regulations instituted stricter environmental controls on solid waste management. Local governments opted to contract with industry to implement the complex, and potentially costly, new solid waste regulations. Large, private waste management companies also responded to the nation's interest in recycling. By 1989, private companies collected about two-thirds of the materials recovered for recycling and processed nearly $80 \%$ of total recovered materials.

The solid waste industry has proven that it is possible to do right by the environment and make a profit. The nation's three largest solid waste companies offer collection, hauling, and disposal services, which together produced revenues in excess of $\$ 17$ billion in 1994. More than 50 smaller companies, each with annual sales of millions of dollars, also provided solid waste management services. Of these, about 30 specialized in the recovery or remanufacturing of waste materials.

Industry revenues for managing America's solid waste in 1994 totaled $\$ 54.2$ billion. Local governments paid $\$ 31$ billion for private trash collection, transportation, and management. Consulting engineering fees cost another $\$ 1.25$ billion. Resource recovery brought private industry another $\$ 15$ billion. Equipment, instruments, and computer systems accounted for the remainder of the cost for managing America's solid waste.

The actual cost of solid waste management probably exceeded $\$ 54.2$ billion because many local governments (rather than contracting with industry) paid staff to collect, transport, and dispose of solid waste. Unfortunately, these costs have not yet been tallied for the country as a whole. 


\section{Role of the Federal Government}

Since 1965, the federal government has sponsored programs to help states and local governments safely and responsibly manage solid waste. The regulation of solid waste combustors and landfills has been a top federal priority. Since the late 1970 s, federal regulations have pushed states, local governments, and private service providers to develop better methods to protect public health and the environment.

The development of new technologies has been a high priority. Many different agencies sponsored MSW research: the U.S. Public Health Service, the Bureau of Mines, the National Institute of Standards and Technology, EPA, the Tennessee Valley Authority (TVA), and the U.S. Department of Energy (DOE).

The federal government also evaluated waste-to-energy systems, encouraged recycling, and developed concepts for integrated waste management. Federal monies were used to assist states with solid waste management planning and in establishing agencies to oversee solid waste management.

The impact of the federal solid waste program was far reaching. In 1960, Americans recycled less than 6 million tons of MSW, or about 7\% of the total MSW generated. In 1993, they recycled and composted $22 \%$ of the nation's total MSW generation, 45 million tons. During the same period, manufacturers developed methods for making lighter-weight glass, paper, plastic products, and packaging, reducing the amount of waste. Open dumps were closed for good and replaced by landfills designed to protect the environment from air and water pollution. Ocean dumping of waste stopped.

Municipal incinerators were shut down and replaced by modern waste-to-energy plants with stringent air-emissions controls. Old-style incinerators had been responsible for about $18 \%$ of the black smoke hanging over U.S. cities (Melosi 1981a). Today's waste-to-energy plants produce less pollution than other kinds of power plants and produce enough electricity to light more than a million homes (AIMS Coalition 1994).

Despite these accomplishments, the current system could be better. The nation's growing population and its relative affluence continue to foster solid waste generation. Local governments need new technologies and analytical methods for recovering energy and materials from solid waste. Manufacturers and consumers need assistance in reducing the amount of solid waste they create.

Even though the federal government has gained a general understanding of solid waste management, it never systematically collected information on state and local solid waste programs. Information, particularly at the local level, remains largely anecdotal. Not surprisingly, state and local governments use many different approaches to managing solid waste, and there are insufficient data to determine which methods work best.

Managing America's Solid Waste describes the federal role in developing better ways to manage the nation's solid waste. It highlights legislation, regulation, the development of solid waste management technologies, and other federal programs aimed at improving solid waste management. This book provides a history of the period from 1965 to 1995 when federal, state, and local governments worked together to improve solid waste management in the United States.

Chapter 2, From Refuse to Solid Waste, discusses the goals of solid waste management in the context of a historical overview of solid waste management in the United States. The chapter highlights efforts by visionary public works managers 100 years ago to introduce methods for safeguarding public health into urban waste management. It discusses events since 1965 that led to the integration of environmental protection into solid waste management. Finally, it talks about using responsible solid waste management planning to wisely manage material and energy resources. 
Chapter 3, Federal Role in Solid Waste Management, describes federal efforts to improve municipal waste management between 1965 and 1995. The chapter highlights the legislation that laid the groundwork for improving solid waste management and provides an overview of solid waste regulations mandated by these laws. The chapter also briefly describes the federal agencies that implemented the federal MSW program.

Chapters 4 to 7 describe the evolution of key MSW management technologies and methods, including waste minimization, materials recovery, composting, energy recovery, and landfilling. These chapters describe the role of federal research and development in the evolution of more efficient and low-cost solid waste management technologies and methods.

Chapter 8, Waste Management Today, discusses how communities are integrating their waste management services to better safeguard the public health, protect the environment, and keep costs under control. The chapter highlights contemporary waste management issues, including landfill practices, flow control, federal regulation, and technology research and development. It concludes with a discussion of whether the nation still needs a federal solid waste program.

\section{Profile: Harvey Alter}

Harvey Alter began his career as a materials chemist with Union Carbide Plastics in the late 1950s. His research interests included the conversion of waste polyethylene to useful chemicals. In 1959, he joined the Gillette Company, where he remained for 14 years.

In the late 1960s, Alter oversaw preparation of some of the company's environmental profiles, which describe the environmental impacts of consumer products. As part of the group's work on packaging waste, Alter obtained a research grant funded under the 1965 Solid Waste Disposal Act from the Bureau of Solid Waste Management in the U.S. Department of Health, Education, and Welfare (HEW). He recounts the story of this endeavor as an example of the pitfalls of collaboration between the government and industry:

The Bureau of Solid Waste Management was interested in a patent our lab had. The patent was for a way to accelerate the deterioration of cellulose with ultraviolet light. We told the Bureau we'd do the work they wanted for a buck, with some restrictions: We'd write a proposal, follow all contract requirements, and donate the $\$ 50,000$ it would take to do the project. The company decided this was the way to contribute to the community.

We submitted our proposal. The Bureau made a site visit and were amazed at our offer of \$50,000 worth of work for a buck. We waited and waited. Then HEW said a buck wasn't enough. It had to be $\$ 1000$. Then the start up was delayed, because the $\$ 1000$ was not in the budget. When we were finally able to make an announcement at a national press conference, there was lots of skepticism. Why were we doing this? Were we serious? Industry was supposed to be the great polluter.

Later, I learned the Bureau was attacked for letting the fox in the chicken coop. We donated $\$ 49,000$ worth of research, but the research supposedly wasn't independent because we donated it. Eventually, the bureau extended the contract. We got a total 
of $\$ 1000$ from HEW and the company donated $\$ 64,000$. The process was not economically successful, but the Bureau's research and development program was advanced. No other company did it that way.

Alter joined the National Center for Resource Recovery (NCRR), a nonprofit research and public information organization devoted to recycling, as technical director of research in 1972. In this role, Alter pioneered standard specifications for materials recovered from MSW and the marketing of these materials. In conjunction with this effort, Alter founded the American Society of Testing and Materials' Committee on Resource Recovery. With Alter as its first chairman, the committee developed standards for the testing and evaluation of MSW.

Alter left the NCRR in 1979 to join the U.S. Chamber of Commerce, where he is currently manager of the organization's Resources Policy Department. During his career, Alter has published more than 125 technical papers and books. 


\subsection{From Refuse to Solid Waste}

Throughout most of time, human beings disposed of garbage in a very convenient manner: simply by leaving it where it fell. ${ }^{4}$

Throughout history, most people have dealt with solid waste by dumping it somewhere - on the floor, in the street, or into decidedly unsanitary open pits. Burning and recycling have also been practiced since prehistoric times. The history of solid waste management in the United States reveals how Americans have improved upon these three basic methods.

From colonial times until the mid-1800s, America's city dwellers disposed of their food waste (garbage) and refuse (trash) by throwing them in the streets. Animals ate most of the garbage, and natural processes, such as the sun and wind, eventually got rid of the trash. Because cities were small and the country was (and continues to be) blessed with abundant land and natural resources, early waste management practices did not have a major impact on the environment. It is also likely that city dwellers at the time had a higher tolerance for filth.

After the Civil War, as cities grew, major sanitation problems developed and there were frequent and often devastating epidemics. By the close of the nineteenth century, women's civic groups and city governments organized sanitation efforts to remedy the filthy conditions. Since that time, the primary goal of those who manage solid waste has been to safeguard the public's health.

During the 1960s, Americans began to realize that pollution threatened the environment upon which they depended for sustenance. As a result, many poor solid waste management methods were eliminated, allowing the environment to recover from years of neglect. Since 1965, the goal of protecting the environment has been second only to that of safeguarding public health.

Today, with better technologies and a deeper understanding of how to prevent environmental pollution, those who manage the disposal of solid waste have a third goal: to wisely manage material and energy resources. Unlike earlier goals, this objective cannot be met by solid waste management professionals alone. The health of America's cities in the twenty-first century will depend on how well cities can integrate solid waste management with pollution prevention, the production of goods, and other community services such as transportation. Conserving material and energy resources as part of solid waste management will help cities create healthy and enduring economic systems.

\section{Safeguarding Public Health}

Refuse has not always been a problem for human societies. Nomadic, rural, and agrarian economies have successfully relied upon natural forces to manage their waste. Sunlight and microbes in water and soils readily decomposed garbage and human waste - as long as population densities remained low. When humans were primarily hunters and gatherers, garbage could simply be left where it fell. When people established permanent settlements (about 10,000 years ago), the situation began to change. Settlements grew larger, laying the groundwork for the world's first cities and the solid waste problems that accompanied civilization.

For much of history, good sanitation practices were the exception, not the rule. In ancient Troy, for instance, inhabitants dropped bones and other rubbish on the dirt floors of their homes,

\footnotetext{
${ }^{4}$ Rathje, William, and Murphy, Cullen (1992). RUBBISH! The Archaeology of Garbage. New York: Harper Perennial, p. 32.
} 
periodically covering their refuse with a new layer of soil to form a new floor. Trojans disposed of larger items, food, and human waste by throwing them into the streets. The city's poor carried off items of value, and foraging animals consumed whatever was edible. The practice of throwing waste into the streets continued in some European and American cities until well into the nineteenth century.

\section{Early History of Sanitation in the United States}

From colonial times into the twentieth century, city dwellers discarded garbage into city streets. The garbage was a source of disease because it contaminated water supplies and served as a breeding ground for flies, rats, and other disease-carrying vermin. Dysentery, bubonic plague, cholera, and typhoid fever are examples of illnesses spread by appalling unsanitary conditions.

On hot summer days, cities reeked with odors from open air markets, rotting garbage, dead animals, animal waste, and leaking privy vaults in the basements of apartment buildings in city slums. Even near the most elegant homes, it was not uncommon to find heaps of garbage and to smell the sickening odors of decaying refuse. Dust and soot were pervasive. If there was a sewer system, raw sewage passing under the streets to the nearest river or ocean contributed to the normal stench of daily life. Town thoroughfares were rife with manure from horses and animals scavenging through heaps of garbage tossed into the streets. Rainstorms turned streets into rivers of slime.

The American Public Works Association (APWA) (1976) credits Benjamin Franklin with designing the first American MSW management system. Beginning in 1792, servants collected refuse from Philadelphia's 60,000 inhabitants and dumped it into the Delaware River. For the next 170 years or so, the nation's waterways provided a convenient method for disposing of solid waste.

The Corporation of Georgetown (now part of Washington, D.C.) passed one of the nation's first solid waste ordinances in $1795 .^{5}$ The law outlawed dumping in the streets and storing refuse on private property. Citizens were responsible for hauling their solid waste out of town or hiring someone to provide the service.

President John Adams hired a private refuse "carter" when he moved into the newly constructed White House in 1800. Refuse from other federal buildings was burned on the grounds of the buildings. However, President Thomas Jefferson initiated a plan to collect solid waste from federal buildings after being sickened by the smell of burning garbage while riding in his carriage. Private waste haulers cleaned Washington's streets periodically during the early 1800s. In 1844, Washington, D.C., extended its waste hauling contracts to include residents willing to pay for the service. Twelve years later, the nation's capital finally began removing noncombustible solid waste at taxpayers' expense. Citizens were still responsible for burning combustible trash (in coal-fired furnaces or home incinerators) and disposing of the ashes.

Although there were sporadic efforts to institute regular solid waste collection services in other American cities during the $1800 \mathrm{~s}$, the practice of dumping waste into the street continued unabated in most places. On rare occasions, city dwellers might carry their trash to a vacant lot or dump it at the edge of town. The combination of animal scavengers and natural decay processes kept the amount of solid waste at "tolerable" levels, at least according to the standards of the time.

\footnotetext{
${ }^{5}$ Laws against littering predate the formation of the United States. According to Harvey Alter (1995), William Shakespeare's father was arrested for littering, and there are inscriptions on the ruins in Pompeii that read, "Do Not Litter."
} 
As the years passed, cities grew larger and sanitation conditions steadily worsened. Sewage went untreated, drinking water became polluted, and increasing volumes of refuse piled up in the streets. Not surprisingly, disease became widespread in urban areas. Epidemics of yellow fever, cholera, smallpox, and typhoid fever were common. Between 1832 and 1873, for example, six cholera epidemics scourged the nation. During the Civil War (1861-1865), more soldiers died of cholera and typhoid than were killed in battle. The chlorination of drinking water, which began in 1908 , played a key role in reversing this trend.

After the Civil War, large numbers of immigrants from Europe flooded East Coast urban areas, which further exacerbated the situation. Between 1860 and 1910, the population of the United States tripled from 31 million to 91 million. The number of Americans living in cities and towns rose more than seven-fold, from 6 million to 44 million. By 1910, 46\% of Americans were urban dwellers. People could no longer ignore their garbage and refuse problems.

As early as 1850, a special Massachusetts state commission had recommended to the governor that cities improve sanitation practices. The commission also recommended a new state public health program to oversee such improvements. The state implemented the latter suggestion in 1869 when it established the nation's first public health agency, the Massachusetts State Board of Health.

The 1850 Massachusetts commission report appeared to recognize a connection between poor sanitation and disease. Like others at the time, the members of the commission erroneously believed that the miasma, or putrid emanations associated with rotting garbage, was responsible for the spread of disease. Twenty years later, Louis Pasteur proved that disease was caused by microorganisms growing in garbage and refuse. By 1890, researchers recognized the role of animals and insects in spreading disease. Public works managers also began making the connection between mounds of filth in the streets and burgeoning public health problems in America's cities.

\section{Early Twentieth-Century Solid Waste Management}

At the beginning of the twentieth century, solid waste was substantially different from that produced today. Garbage, coal ash, and manure were the primary constituents of solid waste. The average New Yorker produced 160 pounds of garbage, 1,230 pounds of ash, and 97 pounds of rubbish (not counting manure) each year-about $20 \%$ more total residential solid waste than the average American produces today. These figures did not even include manure.

As the nation's primary mode of transportation, horses delivered copious amounts of urine and about 20 pounds of manure each onto city streets every day. As recently as 1914, Chicago's streets were the repository for more than 600,000 tons of manure produced annually by approximately 82,000 horses, cows, and mules (APWA 1976). Discarded rags, paper, glass, and metals - the primary constituents of today's solid waste - were not even part of Chicago's waste problem. These items were salvaged by ragpickers for reuse or recycling. Food waste was a significant part of solid waste until the middle of the twentieth century.

About 1890, refuse collection (where it existed at all) consisted of horse-drawn wagons periodically collecting solid waste. Private haulers usually collected waste from industries and commercial establishments, while municipal collections occurred primarily in residential areas.

Before 1900, Cleveland had no public program for managing residential solid waste. Chicago, St. Louis, Boston, and Baltimore simply carted their solid waste to open dumps. Coastal cities such as New York dumped as much solid waste as they could into the ocean. A few cities experimented with adding disinfectants to solid waste, while others burned their refuse to disinfect 
it and reduce its volume. Despite a growing interest in better sanitation, refuse collection and disposal practices changed very slowly in most cities.

In the 1920s and 1930s, many cities and towns replaced their horse-drawn conveyances with open trucks. (By the beginning of World War II, trucks had completely replaced the horse and cart for refuse collection.) By the 1930s, public works managers were well aware that prompt, efficient garbage collection was essential to the health and well-being of America's communities. Solid waste was collected two or three times each week, particularly during the summer when fetid odors of rotting garbage assailed city dwellers.

The basic disposal methods employed at the beginning of the twentieth century were still widely used decades later. Refuse might be deposited in open dumps, burned in open dumps, incinerated, plowed into the ground, dumped into water, fed to livestock, or "rendered." (Rendering was a process in which animal carcasses and food waste were steamed to remove fat. The city of Chicago, for example, operated municipal waste-rendering plants as early as the 1800 s to make grease for the city's cable cars. Tankage, which was the residue left from rendering, was used as fertilizer or feed.)

Incineration was popular until the 1960s when the 1963 Clean Air Act forced many polluting incinerators to close. Several factors were responsible for the popularity of incineration. The method was unequaled for reducing the volume of solid waste and destroying disease-carrying organisms. Incinerators were less expensive than rendering plants and considerably less foul smelling, so municipalities often built them in the most crowded parts of the city. This strategy reduced transportation costs and made it possible to use steam produced by the incinerators for district heating. Unfortunately, incinerator stack emissions contributed to urban air pollution.

The practice of feeding garbage to pigs was relatively common during the first half of this century. A 1941 survey revealed that more than one-fourth of the nation's largest cities were feeding more than two million tons of garbage to swine each year (APWA 1976). Unfortunately, this disposal method was largely responsible for more than 400 cases of trichinosis each year. When another disease, known as vesicular exanthema, ravaged livestock between 1953 and 1955, more than 400,000 hogs were slaughtered to control the epidemic. Afterward, many states passed laws requiring that garbage be cooked before being fed to hogs. The added expense of complying with the new regulations rapidly curtailed the practice of feeding garbage to swine. By the 1970s, less than $5 \%$ of the nation's food waste was consumed by pigs.

\section{The Origin of Modern Municipal Solid Waste Management}

Historians often mark 1895 as the beginning of modern municipal waste management (APWA 1976; Melosi 1981b). That year, Colonel George E. Waring Jr., ${ }^{6}$ was appointed New York City's street cleaning commissioner. Waring was a visionary public works manager. Fifteen years earlier he had designed one of the first sewer systems used solely for human waste for the city of Memphis, Tennessee. The system discharged untreated waste into a nearby river, relying on natural processes to cleanse the water. No one recognized that the assimilative capacity of the river could be exceeded to cause pollution and posed a risk to public health.

Waring saw his role in New York City as not only keeping the city clean and free from disease but also improving the quality of urban life. He was by no means the first public works official to advocate municipal refuse collection and disposal. However, he was one of the first to

\footnotetext{
6 Waring served in the Union Army during the Civil War.
} 
implement the idea. As a result of his efforts, New York City became the model for solid waste management for cities around the nation.

During his tenure in office, Waring was known as the "Apostle of Cleanliness." He employed 2,000 uniformed workers to clean New York City's streets. Waring's biggest challenge was the more than 2.5 million tons of manure deposited on city thoroughfares by horses, pigs, and other animals. Within a few months, he developed a system to clean major thoroughfares each day and other streets regularly, but less often. For the first time, city residents could walk down clean sidewalks and drive through streets without running over piles of garbage and manure. Waring even removed about 60,000 abandoned trucks and wagons from New York thoroughfares. Solid waste was sent to dumps, incinerators, or into nearby waterways.

Despite Waring's innovative street cleaning methods, a substantial fraction of turn-of-thecentury New York City's solid waste was "managed" by loading it onto garbage scows anchored in the East River, often within a few feet of where slum dwellers were bathing. Until 1872, solid waste from the scows went directly into the river. After that, the solid waste was supposed to be thrown overboard after the scows were towed out to sea. Recognizing the health hazards of this disposal method, Waring attempted to make the scows more sanitary. He also reduced the amount of solid waste managed on the scows by instituting a recycling program.

Waring launched programs in schools to educate the children of immigrant parents about his new sanitation methods. Today's secondary school programs that emphasize source reduction and recycling are the modern versions of Waring's visionary ideas. Unfortunately, few of today's school programs discuss Waring's accomplishments.

Public health statistics are consistent with Waring's achievements. During his first year in office (1895), New York City's death rate fell from 26.8 per 1000 to 19.6 per 1,000. The Board of Health attributed much of this improvement to cleaner streets and better solid waste management. The same year, street-cleaning costs dropped, as Waring replaced political appointees with professional sanitation workers who actually got the job done. The APWA (1976) credits Waring's use of scientific and engineering principles to solve waste problems with laying the groundwork for the modern profession of sanitary engineering.

Public works managers in other cities soon followed Waring's lead and initiated solid waste management systems. In many cities, women's groups supported these changes as a vehicle for improving public health. As a result, sanitary conditions in the nation's larger cities slowly improved.

Sanitary conditions in smaller towns did not improve as soon as they did in cities. Until the mid-1960s, fewer than half of U.S. towns with populations greater than 2,500 had solid waste disposal programs. Solid waste management consisted of little more than finding cheap land and dumping garbage on it. There were no federal waste management regulations. Most states did little more than assign local governments responsibility for managing waste, prohibit waste dumping on public property, and conduct campaigns against littering. Only a few towns had ordinances designed to protect the health and safety of workers and the public at solid waste disposal sites.

\section{Recent Changes in Solid Waste Management}

Before World War II, many Americans lived in rural areas and took care of their own solid waste. Local governments controlled hauling in cities. In the decades following the war, many Americans moved to homes in the suburbs where there was no organized trash collection. In some areas, milkmen began doing double duty, delivering fresh milk in the morning and collecting solid waste in the afternoon. This practice marked the beginning of private sector involvement in solid 
waste management. At first, waste hauling companies were small. Even by the mid-1970s, there were no companies large enough to build a first-rate landfill.

Things changed rapidly during the 1980 s, when government regulations forced the public sector to revamp solid waste management methods. Rather than pay for costly new solid waste technologies and management methods, local governments were only too happy to allow the private companies to take over more and more of these responsibilities. A few hauling firms began purchasing smaller companies. The larger firms attracted both residential and commercial customers by offering lower prices and better service. By instituting economies of scale, more efficient collection practices, and better management techniques, these companies were able to rapidly expand their operations. Many offered both collection and disposal services, a combination that was particularly attractive to local governments.

Some municipalities welcomed the opportunity to shift responsibility for financing and labor management to the private sector. By the late $1980 \mathrm{~s}$, fewer than $40 \%$ of the nation's local governments operated residential trash collection and only $27 \%$ conducted their own commercial waste collection.

\section{Changes in Waste Composition}

After World War II, the composition of solid waste changed. Within a relatively short period of time, packaged goods became widely available. The growing use of paper packaging and plastic containers helped reduce the amount of food in residential solid waste. At the same time, packaging began to account for larger fractions of the waste stream.

Fuel oil and natural gas replaced coal in many residential and commercial furnaces, all but eliminating ash from solid waste. Then during the 1950s, American companies began to manufacture more and more disposable goods - from paper plates and paperback books to razors and diapers. The increase in disposable goods, particularly paper products, resulted in greater quantities of solid waste.

Fortunately, several new devices helped alleviate some problems associated with these developments. The widespread use of kitchen garbage disposals kept significant amounts of food waste out of MSW. Less food waste meant the trash set out in the alley did not begin to stink as quickly. Cities discovered they could collect solid waste less often, and weekly trash collection soon became a norm. Because collection is the single most expensive component of a solid waste management system, the decline in food waste helped control costs (APWA 1976).

\section{Changes in Collection and Hauling}

The design of trucks to pick up solid waste evolved to meet cities' needs for more economical collection. In addition to buying more modern trucks, many communities began building and operating transfer stations during the 1960s. An increase in the number of transfer stations made it cost effective for cities to transport solid waste greater distances for disposal. During the late 1960s and early 1970s, compaction vehicles largely replaced ordinary trucks. New truck designs reduced crew size and costs. Multi-use trucks, which appeared during the late 1980s and early 1990s, consisted of a compactor for mixed waste and individual compartments for separated recyclable materials. By the second half of the twentieth century, most cities were using more efficient solid waste collection and hauling services.

Today, long-distance hauling has become an integral part of urban solid waste management. Cities increasingly rely on large, regional landfills for solid waste disposal. A modern compaction truck can now haul as much solid waste as road weight limits permit (usually 23 tons). Rail cars can haul as much as 4,000 tons. Rail transport has become more economical for waste transport than 
trucks when solid waste is carried more than 125 miles for disposal. New equipment has been recently added for loading and unloading solid waste from trucks to railroad cars.

Despite its importance to solid waste management, solid waste collection has received little attention from the federal government. Costs for collection account for as much as $65 \%$ of the total costs in a modern municipal waste management system. Even so, energy usage for collection is small in comparison to the amount of energy that could be recovered from solid waste, ${ }^{7}$ according to a study done by the Energy Research and Development Administration (ERDA) in the mid-1970s. Research at ERDA and later DOE therefore focused on waste-to-energy conversion. Despite the environmental impact of using tens of thousands of low-mileage, diesel-fueled trucks throughout the nation, the EPA spent little time evaluating this particular aspect of solid waste management.

\section{Protecting the Environment}

For more than two centuries, Americans took the environment for granted. It appeared to be a limitless reservoir of raw materials and an unlimited repository for waste. In the years following World War II, as the nation grew more affluent and its population expanded, the composition and amount of solid waste changed. These changes had a profound effect on the environment. Consumers were enticed by television advertising and attractive packaging to purchase convenient, disposable products such as paper plates and cups, plastic tableware, diapers, razors, and nonreturnable bottles. In addition, a burgeoning packaging industry revolutionized the distribution and marketing of meats, fruits, and vegetables, creating new packaging waste. At the same time, however, residential food waste plummeted, thanks to better packaging, the growing popularity of garbage disposals, and the fact that food waste, such as meat trimmings and vegetable peels, was collected at processing plants.

People got rid of most of this extra solid waste by setting it out for the trash collector, who delivered it to a municipal incinerator or deposited it in the town dump. Homeowners, particularly in the West, burned wastepaper in homemade incinerators. Americans also threw pop cans, candy wrappers, and cigarette butts out the windows of their automobiles. To make matters worse, when their automobiles wore out, people often abandoned them in their backyards or in a decidedly unappealing junkyard. ${ }^{8}$

As more and more people threw away more and more trash, several problems became apparent: incinerators without pollution controls were adding pollutants to the air in cities, dumps were an eyesore and a hazard to health, and litter was piling up along the nation's highways. ${ }^{9}$

The increase in the amount and composition of solid waste that occurred after World War II placed new burdens on MSW management systems. In the 1960s, incineration and open dumping came under fire - the result of decades of poor solid waste management practices. Americans had had bad experiences with polluting solid waste incinerators since the end of the nineteenth century.

\footnotetext{
${ }^{7}$ Solid waste collection consumes less than 0.01 Quad, while energy recovery from solid waste could total as much as 2.5 Quads. A quad is 1 quadrillion British Thermal Units (Btus) of energy.

${ }^{8}$ Although the obsolete car became a big headache, it rarely impacted solid waste management, because abandoned cars were not usually disposed of in landfills. Nevertheless, steel recovered from scrap automobiles is often used to exaggerate MSW recycling rates.

9 The first national campaign against litter occurred in the 1950s. Overnight, "litterbug" became a household word. Since then, national organizations such as Keep America Beautiful, Inc. have urged individuals, civic organizations, and communities to take responsibility for reducing litter. By the middle of the 1960s, however, it was clear that litter was just a small part of the problem the nation faced in managing its solid waste.
} 
Smoke, foul odors, and blowing trash and ash particularly bothered city dwellers. In addition, poorly managed city dumps emitted foul odors and frequently caught fire, further polluting the air. One such fire, at Washington, D.C.'s Kenilworth dump in 1968, engulfed three small children, killing one of them. The incident evoked public outrage. The dump was forced to close, and Congress was inspired to put a stop to open dumping. Steve Levy of DOE describes the Kenilworth dump prior to its closure:

Kenilworth was a terrible, open-burning dump. A couple of hundred scavengers actually lived on the landfill. They had built shacks there, which [nearby residents] called the Kenilworth Hilton.

All day long [the dump] would have trucks coming in and people scavenging. Then at 5 o'clock every night, [workers] would dump gasoline or used motor oil on the area they had covered and set it on fire. The fire would burn all night - to reduce the volume of trash, because the landfill was a small site. The smoke would turn the whole east side of town black. Driving up Kenilworth Avenue, you'd have to put your headlights on at 5 p.m. in the summer, because it was so dark near the dump.

When [the Public Health Service] came in with the national program in 1966, we tried to get that dump closed. It finally closed after some kids who were scavenging got caught in a fire and were killed. That's when they shut it down and moved the landfill down to Lorton.

In 1965, President Johnson recommended that the federal government help states in solving pressing solid waste disposal problems that were causing serious environmental harm. Congress obliged by passing the Solid Waste Disposal Act. This legislation marked the entry of the federal government into the field of solid waste management. During the next two decades Congress passed several other key pieces of legislation impacting solid waste. The laws and the federal programs they spawned are described in Chapter 2, Federal Role in Solid Waste Management.

By 1970, Americans were becoming aware of the environmental problems associated with solid waste disposal. Public health officials implicated air pollution as a major factor in deaths from emphysema and chronic bronchitis. The pall of black smoke and the odors emanating from old-style municipal incinerators (without emissions controls), industrial plants, power plants, and even hospitals helped convince people that air pollution was a serious problem. Scientists began warning the public that environmental problems were only likely to worsen as the nation's economy and population both continued to grow. Public concern in response to these developments was channeled into action on April 22, 1970, with the celebration of the nation's first "Earth Day."

Despite public concerns about the impact of solid waste management on the environment, sanitation services during the 1970s remained as they had been for most of the twentieth century. Street cleaning, refuse collection, and waste disposal were the standard services. Only about $6 \%$ of the dumps in the United States met the minimum requirements for a sanitary landfill. There were also tens of thousands of unregulated, unauthorized dumps in use throughout the country.

During the 1970s, local governments increasingly relied upon land disposal for solid waste as the use of incineration plummeted in response to new federal clean-air regulations. The regulations forced incinerators to install air-pollution controls or shut down. Because emissions 
controls often cost as much as the original incinerator, local governments were reluctant to invest in them. Cities turned to the cheaper alternative: open dumping.

During the 1970s and 1980s, problems with poorly managed hazardous waste contributed to the public's perception that waste of any kind posed a significant threat to public health and the environment. In 1978, residents of Love Canal (near Niagara Falls, New York) were evacuated from their homes, which had been built over an abandoned chemical-waste dump. Subsequent evacuations of other communities occurred over the next few years. The nation reeled from the impacts of its laissez-faire attitude toward disposal of hazardous waste. Fears of toxic chemicals revived in 1984, when a chemical release at the Union Carbide plant in Bhopal, India, claimed 3,500 lives. In 1986, 184 landfills were recommended for the Superfund National Priorities List. All but two of them had accepted hazardous industrial waste along with solid waste.

These developments encouraged Americans to view solid waste as an external threat rather than the logical consequence of their lifestyles. Many people confused the risks posed by hazardous waste and the far more benign MSW. This confusion added to the challenge of MSW management in the 1970s and 1980s and fostered a crisis mentality with respect to solid waste. People found it difficult to make the connection between their own behavior as consumers and the challenges the nation faced in disposing of hundreds of millions of tons of MSW.

\section{The Garbage Crisis Mentality}

Solid waste management came back into the limelight in 1987 after being ignored for a decade while the nation worried about hazardous waste problems. An incident purportedly related to poor solid waste management grabbed national headlines. The media and the public panicked, convinced there was a terrible crisis brewing. What actually happened was that the infamous garbage barge, the "Mobro 4000," sailed away from Long Island and failed to find anywhere to put its load of solid waste. Ironically, this situation had nothing to do with declining numbers of landfills and rising costs for solid waste disposal, as widely believed. The barge was simply a get-rich-quick scheme gone awry when its captain failed to find any city along the East Coast willing to take New York's solid waste for less money than he'd already been paid. The infamous garbage barge eventually ended up in Islip, New York, where its ill-fated journey had begun.

The garbage crisis of 1987 was a good example of the law of unintended consequences. State and federal efforts were successfully shutting down thousands of small, poorly designed and operated landfills. Because there were now fewer landfills, spaced further apart, prices for solid waste disposal began to rise. The crisis mentality was magnified by both the environmental movement and the solid waste management industry. Private industry, which was growing rapidly, looked at the "crisis" as an opportunity to increase business. The perception of a crisis allowed environmental groups to tout the benefits of recycling. The news media aided and abetted with stories about how the nation was running out of landfill space. Harvey Alter (1995) recounts what really occurred:

People went around saying landfills were closing: "It's a crisis!" I applauded [this development]. Landfills either close because they're full or because something is wrong with their operation. Thousands of small landfills closed during the 1980s. But the net U.S. landfill capacity increased! Larger landfills opened to replace the ones that closed.

[People thought we had] a crisis [because they counted] the number of facilities rather than [adding up] landfill capacity. The market drove prices higher for 
landfilling [because waste had to be transported longer distances.] [This occurred because] it was politically impossible to site landfills near cities.

There was no garbage crisis in 1987. In contrast to public perception, solid waste management methods were much improved. By 1988, the number of U.S. landfills declined from 14,000 to about 8,000 , with uncontrolled dumping all but eliminated. (The number would fall to less than 2,900 by 1995 , according to a survey by the National Solid Waste Management Association.) Newer, larger sanitary landfills replaced older facilities. The new landfills not only safeguarded public health, they also protected the environment, at least in the short run.

By 1988, only a handful of incinerators were still in operation. More than 100 waste-toenergy combustion facilities had come on-line. Drop-off programs and curbside recycling programs had sprung up across the country. As a result, the percentage of solid waste recycled had almost doubled, rising from 7\% in 1965 to 13\% (in 1988). Municipal composting of yard waste had appeared in a few locations.

Despite significant changes, the public viewed solid waste as a genuine threat. And because 1988 was an election year, the federal government came under pressure to do something about solid waste. EPA's Steve Levy (1995) remembers the illogic of the prevailing wisdom:

What were we in the federal government going to do? And the answer people came up with was - recycle. Suddenly we had a green mentality, an environmental ethic. People were no longer looking at solid waste as a public works issue, they were looking at it as an environmental issue.

And what was the environmental position? Don't produce it; reuse it, and recycle it. Stop building landfills and incinerators. It just seemed obvious to people that it was more "environmental" if you didn't dispose of garbage.

The 1987 garbage crisis reflected the nation's ambivalent attitudes toward responsible solid waste management. For most of this century, Americans dealt with solid waste by ignoring it for as long as possible. Eventually, problems that might easily have been solved with consistent attention "suddenly" escalated into a "garbage crisis." The crisis then mobilized citizens and government officials to take "action" until people felt sufficiently reassured to forget about solid waste once again. Harvey Alter (1995) explains why, in his opinion, Americans move from crisis to crisis in dealing with municipal solid waste: "The country seems to have had a garbage crisis every 15 to 30 years since 1875. I've gone through three such cycles so far. The cycles go on because people put a bandaid on a festering wound and called it cured. The wound keeps festering so it comes up again as a new crisis. Every time, the problems are only partially addressed."

Since World War II, Americans have repeatedly learned and forgotten three important lessons about solid waste management:

- Solid waste management improves to the degree that local governments invest in better analytical methods and more efficient technologies.

- Better technologies and methods come from ongoing research and development, including the kind of long-range basic research funded by the federal government. 
- Public health suffers if solid waste management fails to use the best available technologies and methods.

Even as policy makers grapple with issues surrounding greenhouse gas emissions and global climate change, the nation appears to have forgotten these lessons once again.

\section{Solid Waste Management and Climate Change}

During the late 1980s, scientists began warning the public that carbon dioxide, methane, and other greenhouse gases were accumulating in the atmosphere in sufficient quantities to pose a threat to the stability of global climates. Researchers speculated that a buildup of greenhouse gases could lead to world-wide warming in the twenty-first century. This new threat focused the attention of waste management professionals on landfills.

Landfills generate methane, typically for decades, and release the gas gradually into the atmosphere. Many larger landfills and a few smaller ones recover landfill gas. Once a landfill has a collection system in place, it can recover up to $75 \%$ of the gas generated; but fewer than $5 \%$ of landfills have collection systems.

There are no data regarding the actual amount of greenhouse gases emitted by landfills, but EPA estimates suggest they may contribute as much as $35 \%$ of U.S. greenhouse gas emissions (Thorneloe 1996). Because landfills are one of the few sources of greenhouse gases that have the potential to be controlled, it may be advisable to systematically measure methane emissions from landfills to test the accuracy of the EPA estimates.

Accurate information is necessary for creating effective public policy aimed at controlling landfill emissions. For example, there is currently much debate about whether it is economically justifiable to try to control landfill emissions. The debate cannot be resolved without good data proving that landfills are as large a source of emissions as EPA models suggest.

\section{Wisely Managing Material and Energy Resources}

The possibility of global climate change has begun to change the way people think about solid waste disposal. Environmental protection is suddenly more complicated than adding emissions controls to incinerators, liners to landfills, or closing dumps. Rather, it appears to demand change in the fundamental ways in which people obtain energy, food, fiber, shelter, and consumer goods.

People are realizing they need to work in concert with the planet to provide for their needs, use material and energy resources more efficiently, and create less solid waste. The high energy and materials requirements of today's industrial societies may seriously impact the environment over the long run. This new thinking will significantly impact solid waste management in the future.

Most of the time, the nation manages solid waste in ways that protect the public health and the environment. In the future, better methods for managing the nation's material and energy resources are likely to be developed and implemented as well. Systematic studies are already under way to examine ways to reduce the flow of energy, materials, and waste through industrial systems and minimize the impact of human activities on the natural environment.

The President's National Science and Technology Council provided a road map for developing such methods in April 1995 with the publication of a national environmental technology strategy (National Science and Technology Council 1995). The strategy discussed the continuing need to remediate past environmental damage and offered a framework for shifting the emphasis from solid waste management to pollution prevention and the more efficient use of resources. The strategy envisioned the creation of communities where "waste" is not only minimized but also used 
and used again as resources. Material and energy resources would no longer be treated as commodities to be squandered; rather, they would be conserved and used efficiently.

In the future, America's communities would have the option of adopting advanced solid waste management methods, including planning strategies that anticipate and prevent environmental pollution; solid waste management systems that are fully integrated with manufacturing, agriculture, energy, transportation, and other community operations and services; integrated waste-disposal systems designed for each community's particular needs; and sufficient materials and energy recycling to relegate the use of landfills to a minor role in solid waste management.

Wise management of material and energy resources presupposes a shift in the way Americans organize their economy and community services, from reacting to environmental damage to planning for environmentally sustainable development. Individuals, industry, labor, communities, nongovernmental organizations, and state and federal governments will all need to work together to design tomorrow's public services.

The task of integrating solid waste management with all facets of community operation will fall primarily on solid waste management professionals. They may have help from other stakeholders in national waste management industry associations, state agencies, local officials, and interested citizens. The task will be daunting. Lanny Hickman (1995-97), formerly of the Solid Waste Association of North America (SWANA), explains:

There's a disconnect people don't seem to understand: Right now, the people who mine the minerals and make the products we use are not connected with the people who pick up the trash and make it go away. You can't expect municipal waste management people to try and internalize all the life cycle costs of a material, from its mining to its ultimate destiny, because they don't have any control over that system. They control only what's assigned to them. So far, the federal government hasn't tried to connect those pieces in any way whatsoever, or try and bring about changes in the way we use materials.

However, unless a connection is made between manufacturing and waste generation, meaningful efforts to conserve energy and materials while reducing waste generation will remain largely visionary.

One way to begin is by replacing the regulation of specific technologies and methods with flexible, performance-based standards. This type of regulatory approach would encourage industry to develop innovative and cost-effective technologies for complying with the standards. The development of better technologies would enhance U.S. competitiveness in global markets.

In contrast, the more rigid regulatory policies of the past mandated control of specific pollutants and often impeded technological development. Technologies capable of meeting regulatory standards were adopted regardless of whether industry could have come up with better performing, lower-cost solutions. Harvey Alter (1995) explains why we need to improve our regulatory system: "If we are going to advance, we have to encourage research and innovation. But the regulation in this country doesn't encourage innovation. Our environmental regulatory system is overly-prescriptive in methods and results. When you do that, you don't have innovation." To avoid this problem in the future, the public and private sectors can cooperate in developing affordable, innovative technologies for reducing waste and lowering energy and materials use. 
It is not yet clear whether Congress, federal agencies, and the American public endorse a vision of technology-based, environmentally sustainable development. Assuming that they do, it is crucial that environmental regulation and technology development occur within separate, independent agencies. Separating regulatory policy setting from technology development sets the stage for credible research and development. And it fosters the development of flexible, performance-based standards necessary for innovation in solid waste technology. Alter (1995) offers a novel proposal:

We need energy research and development, but we don't necessarily need a Department of Energy. I believe we should have a National Institutes of the Environment (modeled after the National Institutes of Health). Such an organization could perform a centralized environmental research function independent of the regulatory bodies. It could include technology development, which is currently done poorly in this country. If they did that, they could move the DOE work in energy efficiency and renewables there.

EPA hasn't been doing this kind of research, because they've been pushed into the regulatory arena. EPA is not the environmental protection agency; it's the environmental regulatory agency. Always has been. Regulating and research don't go together unless you do research to improve the regulations, and even that's problematical.

\section{Profile: H. Lanier Hickman, Jr.}

H. Lanier (Lanny) Hickman, Jr., joined the U.S. Public Health Service in 1956 and began working for the agency's solid waste program 10 years later. At the time, the solid waste program emphasized both research and development and the provision of technical and financial assistance to state governments. Along with others from the Public Health Service's solid waste program, Hickman was transferred to EPA's Office of Solid Waste in 1971 when EPA took over the Public Health Service's solid waste programs. EPA's Steve Levy (1995) recalls that Hickman played a key role in the federal program in the early years: "Lanny was a major part of what we did. Since that time, he has served as a kind of historian [of what happened]. When the Reagan administration came into office in 1981, EPA was told to get rid of all its historical files on municipal solid waste. Lanny rescued them, and today they are in the library at the Solid Waste Association of North America."

In 1978, Hickman joined the Governmental Refuse Collection and Disposal Association (GRCDA), a professional association formed in 1961 in Los Angeles by a group of six local sanitation superintendents. GRCDA had 900 members in 1978. Hickman describes his vision for GRCDA when he first joined the organization: "One of our fundamental precepts in the federal program was that we never used the terms garbage, refuse, or trash. We used the term solid waste all the time. We chose the name. We changed the concept from garbage to solid waste management. That's what SWANA is dedicated to today: training, education, technical assistance, and research. What we had in the EPA Office of Solid Waste has been recreated under the banner of SWANA."

Under Hickman's leadership, GRCDA became the Solid Waste Association of North America, with headquarters in Silver Spring, Maryland. Today, SWANA has more than 6,000 
members, about $74 \%$ of whom work for municipalities, counties, solid waste authorities, or specialpurpose districts. Most are managers or supervisors within government agencies or private waste services providers. SWANA provides conferences, training, certification, technical assistance, advocacy for best practice, and other professional services.

In recent years, Hickman emphasized strategic planning as he prepared his organization for the unique challenges of solid waste management in the twenty-first century. Hickman retired from SWANA in September 1996. He continues to teach, lecture, and write. 


\subsection{The Federal Role in Solid Waste Management}

Ignorance is one of the biggest handicaps we face when it comes to deciding, as a society, whether or how to throw various kinds of garbage away. ${ }^{10}$

With the exception of the military and the U.S. Public Health Service, the federal government had no involvement with solid waste management until 1965. Prior to that time, the military's involvement in solid waste management was limited to overseeing waste disposal at military installations and encampments. The U.S. Public Health Service ran a small solid waste research program as part of its mandate to oversee sanitation and other matters affecting public health.

The federal government's limited role in solid waste management began with efforts to reduce the impacts of pollution on public health. In 1899, Congress passed the Rivers and Harbors Act, which gave the U.S. Army Corps of Engineers jurisdiction over waste discharges into navigable waters. In time, concerns about water pollution led to limitations on ocean dumping and the prohibition of dumping solid waste into streams, lakes, and rivers. Because of the limitations imposed on water dumping, land disposal became the dominant method in twentieth-century solid waste management.

During the 1950s, Congress enacted the Public Health Service Act, which authorized the surgeon general to undertake solid waste research as it related to the spread of communicable diseases and to develop appropriate regulations. With an annual budget of less than $\$ 0.5$ million for these activities, the U.S. Public Health Service made little headway in dealing with such serious problems as open dumping and incineration.

The federal government took no further action until 1963, when the mayors of Chicago, New York, and other cities urged the federal government to get involved with solid waste management. Public works officials were particularly concerned that garbage incinerators (lacking all but the most rudimentary emissions controls) were significantly contributing to air pollution. Steve Levy (1995) recalls the nature of garbage incinerators of the time:

Incinerators were built through the 1950s and into the 1960s by different people using different designs. Some worked better than others. And then the Clean Air Act came along. Suddenly air pollution became an issue. Before then, people didn't recognize it as a health hazard. Your clothes got dirty, and you got soot on your window sills. Then in the early 1960s, you started to have some real environmental incidents - there were a couple of killer smogs in England. All of a sudden, people realized the black smoke wasn't just a nuisance; it was a health hazard.

In those days, air pollution control for an incinerator was an "expansion chamber." A duct opened up into a big room where [combustion] gases were allowed to slow down. The theory was that the heavy particles would fall out before the gas went up the chimney. That was IT! That was air pollution control.

10 Rathje, William and Murphy, Cullen (1992). RUBBISH! The Archaeology of Garbage. New York: Harper Perennial, p. 46. 
The first advancement to the expansion chamber was to keep the particles from getting re-entrained in the exhaust by using "wet bottom" expansion chambers with two inches of water in the bottom. The idea of electrostatic filters, or baghouses, or scrubbers, or cyclones - none of that stuff existed in the mid-1960s. You just had black smoke coming out of the stacks.

Congress passed the nation's first Clean Air Act in 1963 in response to the public outcry against urban air pollution. The new law allocated $\$ 95$ million to air pollution control but produced few lasting results. Incinerator emissions and smoke from fires set in city dumps continued to fuel growing concerns about inadequate solid waste management methods.

By 1965 , these concerns spurred the federal government to get involved with solid waste management. The government passed new laws, initiated programs to provide assistance to state governments, undertook the development of new solid waste management technologies and methods, and created guidelines and regulations aimed at improving solid waste management. Federal initiatives resulted in major improvements in solid waste technologies and methods.

This chapter provides an overview of the federal legislation, programs, and regulations that have had an impact on solid waste management since 1965. Table 3.1 provides a concise history of the federal MSW program presented in the following pages. The chapter concludes with brief descriptions of the federal agencies responsible for implementing federal solid waste programs.

\section{Legislation}

Congress enacted a series of laws between 1965 and 1984 that transformed the nation's solid waste management practices. The laws included the 1965 Solid Waste Disposal Act, the 1970 Clean Air Act, the 1970 Resource Recovery Act, the 1976 Resource Conservation and Recovery Act (RCRA), the 1977 Clean Water Act, the 1978 Public Utility Regulatory Policies Act (PURPA), the 1980 Comprehensive Environmental Response, Compensation and Liability Act (CERCLA), and the 1984 Hazardous and Solid Waste Amendments to RCRA, or HSWA. Thanks to these laws, federal and state regulations, and better technologies, pollution caused by poor solid waste disposal practices is much less a problem today than it was in the 1960s.

\section{The Solid Waste Disposal Act}

In 1965, Congress passed the nonregulatory Solid Waste Disposal Act as Title 2 of the 1965 amendments to the 1963 Clean Air Act. Because it had responsibility for solid waste, the U.S. Public Health Service actively promoted passage of the bill. ${ }^{11}$ The agency played a major role in its implementation as well. Levy (1995), who worked for the U.S. Public Health Service at the time, explains why the new law was needed:

11 Early leaders of the federal solid waste program included Wes Gilbertson, Leo Weaver, and Dick Vaughan. Wes Gilbertson was responsible for the U.S. Public Health Service's modest solid waste activities prior to the passage of the Solid Waste Disposal Act. He was instrumental in convincing Congress of the need for a federal role in solid waste management and helped write the landmark legislation. Weaver became the first chief of the U.S. Public Health Service's new solid waste program after the passage of the Solid Waste Disposal Act. Vaughan, the nation's assistant surgeon general, became head of the Bureau of Solid Waste Management in the Department of Health, Education, and Welfare. He retired shortly after EPA was founded. 


\section{Table 3.1 Concise History of Federal Municipal Solid Waste Management Program}

1963 Clean Air Act allocates \$95 million to air pollution control.

1965 The Solid Waste Disposal Act (enacted as Title 2 of the Clean Air Act amendments) recognizes refuse disposal as a national problem, launches a federal MSW research and development program, and sets up grants to states and municipalities for new disposal programs. The U.S. Public Health Service and the Bureau of Mines are given enforcement responsibility for the law.

1969 National Environmental Policy Act (NEPA) creates the Council of Environmental Quality, with responsibility for national policy on solid waste generation and disposal.

1970 The nation celebrates the first Earth Day on April 22.

The Environmental Protection Agency is established. The agency brings together environmental divisions from the Departments of Health, Education, and Welfare; Agricult;re; and Interior; and other federal agencies. Since 1970, EPA has provided information on solid waste management and sponsored research on MSW collection, disposal, and recycling.

The Clean Air Act grants the federal government broad regulatory powers to protect and enhance air quality. The law will have tremendous impact on incinerator operations.

The Resource Recovery Act amends the Solid Waste Disposal Act, shifting emphasis in the federal program from disposal to resource recovery. It gives federal jurisdiction over hazardous waste. It will help municipalities improve landfill practices.

1972 The Marine Protection Research and Sanctuaries Act attempts to curtail ocean dumping but will meet with little success.

The Water Pollution Control Act creates a program to protect and enhance the nation's ground and surface waters. It will impact most waste management methods, including landfilling, composting, recycling, and energy recovery.

1974 The Energy Reorganization Act mandates the formation of the Nuclear Regulatory Commission and the Energy Research and Development Administration, whose mission is to develop domestic energy resources.

The Non-Nuclear Research and Development Act mandates federal research on the productive use of waste.

The Solar Energy Research, Development and Demonstration Act mandates the establishment of a Solar Energy Research Institute (SERI) (now the National Renewable Energy Laboratory [NREL]) to accelerate the development of solar energy technologies, including waste-to-energy conversion.

1975 The newly chartered Energy Research and Development Administration (ERDA) assumes responsibility for the nation's renewable energy research and development, including energy recovery from MSW.

1976 The Resource Conservation and Recovery Act (RCRA) establishes a federal involvement in solid waste management and emphasizes aid to states and municipalities in resource recovery and planning. This law divides waste into two categories: hazardous and non-hazardous. It directs EPA to develop criteria for distinguishing sanitary landfills from open dumps.

1977 Congress creates the U.S. Department of Energy to broaden federal control over energy, including energy from waste. DOE delegates responsibility for managing MSW programs to Argonne National Laboratory until 1986, when responsibility is consolidated at NREL. 


\section{Table 3.1 Concise History of Federal Municipal Solid Waste Management Program (Concluded)}

1980 Energy Security Act directs DOE to prepare a plan for developing systems to recover energy from waste.

The Comprehensive Environmental, Response, Compensation and Liability Act, aka Superfund, provides funding and federal enforcement for cleaning up hazardous waste sites. Numerous older landfills will be declared Superfund sites.

1984 The Hazardous and Solid Waste Amendments to RCRA direct EPA to revise regulations for MSW landfills.

1988 The Ocean Dumping Ban Act mandates the end of ocean dumping.

1989 EPA publishes The Solid Waste Dilemma: An Agenda for Action, which outlines a strategy for addressing the nation's solid waste management issues.

1989-

1991 Federal agencies implement programs to reduce waste production, recycle, and purchase recycled materials.

1990 The Clean Air Act Amendments mandate that EPA develop stricter regulations for landfills and waste-toenergy facilities.

1991 EPA promulgates comprehensive air emissions standards and guidelines for solid waste combustors.

EPA promulgates regulations for MSW landfills. Created in accordance with Subtitle D of RCRA, the regulations set forth minimum standards for landfill location, design, operations, groundwater monitoring and protection, closure and post-closure care, and financial assurance.

1992 The Energy Policy Act continues support for energy recovery technologies, including the recovery of methane from solid waste and the development of refuse-derived fuel for co-firing with coal in industry and utility boilers.

1995 The Bridge to a Sustainable Future, developed by the President's National Science and Technology Council, articulates an environmental technology strategy. The strategy includes using sophisticated MSW management in creating sustainable communities.

EPA promulgates more restrictive air emission standards and guidelines for waste combustors. The regulations ensure that waste-to-energy facilities are among the cleanest power sources in the nation.

1996 EPA promulgates air emissions standards for MSW landfills. 
By 1965, we had begun to realize there were some public health implications with solid waste. Cities were growing, residents were beginning to encroach on dumps, and the environmental movement was beginning. So in 1965, Congress decided solid waste required direction from the federal government. We needed to define what was good solid waste management and what were good technical practices. They assigned [the problem] to the Public Health Service because it was a public health issue, a sanitation issue.

The Solid Waste Disposal Act created the Bureau of Solid Waste Management in the HEW. The U.S. Public Health Service was part of the same department. The bureau took charge of overseeing the management of waste from residences, commercial establishments, and industry. The U.S. Public Health Service and the Bureau of Mines, in the Department of the Interior, were given responsibility for implementing the law. The Bureau of Mines was responsible for waste created by mining and mineral extraction. The U.S. Public Health Service initiated an expanded solid waste research program.

By passing the Solid Waste Disposal Act, Congress recognized solid waste disposal as a national problem. To solve the problem, the new law mandated a federal research program to develop better solid waste management technologies and methods. The new program was designed to encourage states to implement better solid waste management methods, provide technical assistance to state and local governments, and sponsor the development of better technologies and methods. Levy (1995) recalls the programs and ideas that grew out of the new law:

The Public Health Service had a big influence at that time. We developed a research and development program to begin research into the science of solid waste management. We also started a grant program after 1970 so communities could do engineering management studies to figure out the best economic and technical choices rather than continuing with ad hoc, seat-of-the-pants kinds of things.

This law was the first time the term "solid waste" came into our glossary. The words we used to use were refuse, garbage, or trash. The new term meant that solid waste was no longer just another thing that municipalities had to manage as part of their public works; solid waste was now a science and technology of its own.

Congress recognized that solid waste management, particularly in large urban areas, was no longer just a local issue. The Bureau of Solid Waste Management provided funding for states to develop solid waste management plans. At the time, there were no state solid waste agencies, and only five states even had employees responsible for solid waste management. The planning money laid the groundwork for state solid waste agencies across the nation. By 1975, all 50 states had adopted solid waste regulations. (Federal support for state solid waste planning was discontinued in 1983. As a result, there were fewer than 10 full-time employees at the state level working in solid waste by 1996.)

The Bureau of Solid Waste Management was authorized to provide technical and financial assistance to state and local governments in upgrading solid waste management programs. Unfortunately, relatively few communities availed themselves of this assistance. 


\section{Mission 5000}

In 1968, the U.S. Public Health Service launched the "Mission 5000" program with a goal of closing 5,000 open dumps across the country within 6 years. At the time, nearly 20,000 small community dumps dotted the landscape. Except for occasional fires set to create more space and reduce the vermin problem, most of these dumps received no attention, let alone management. The majority were located close to cities and towns, but sufficiently out of the way to avoid offending local citizens. Little care was taken in the design of such facilities.

Many open dumps were situated on riverbanks. Such locations created open dumps in perpetuity: Periodic flooding washed the contents downstream whether or not the dumps continued to accept new solid waste. The U.S. Public Health Service's goal was to close the dumps in particularly poor locations and upgrade the design and operations of those that remained open.

\section{New Professionalism}

During the late 1960s, the U.S. Public Health Service established graduate-level fellowships for students in environmental sciences or engineering who wished to specialize in solid waste. The fellowship program marked the beginning of a new professionalism in solid waste management. Levy (1995) explains:

One of the key underpinnings of the Solid Waste Disposal Act was that it enabled the Public Health Service to establish university master's degree programs in solid waste. With the graduate programs, civil or mechanical engineers would come out of undergraduate school and go into a one-year program with a Public Health Service fellowship and get a master's in environmental science or engineering with a solid waste specialty. From the late 1960s onward, these programs developed practicing professionals. Many of them started engineering consulting firms or became state solid waste program directors. If you look at people today who have been in this business 25 to 30 years, they all go back to that same genesis.

However, the trend toward developing solid waste professionals did not develop deep roots, according to Harvey Alter (1995):

What happened to the upsurge in the mid-1960s for professionalism? Federal initiatives, especially RCRA, got in the way. The promise of free money caused a lot of states to stop doing what they were doing. Solid waste management education in this country stinks. It smells like the cities did in 1875 . It is so poor. There are so few schools doing it and even fewer doing graduate programs. The typical civil engineering grad takes one course in solid waste. The whole thing has gone backwards since the 1965 Solid Waste Disposal Act. That law supported an M.A. in solid waste. It's hard to get a graduate degree anymore.

H. Lanier (Lanny) Hickman, Jr., formerly of SWANA, agrees that the demise of federal support for solid waste research has hurt professional training programs at the university level. However, under his leadership, SWANA worked hard to ensure that training and proficiency certification remained available. Hickman (1995-1997) says: "Many states require training and certification for solid waste professionals, but few of these provide training. SWANA continually 
presses for the highest standards for certification of practices. SWANA offers certification training courses now, but SWANA certification is voluntary."

\section{Grants to Improve Solid Waste Management}

In the 1970s, EPA and ERDA made grants available to local governments interested in improving solid waste management. The grants supported feasibility studies for demonstration projects of technologies to replace open burning of solid waste. They were structured to allow the federal government to pay two-thirds of the cost of local programs and three-fourths of the cost of regional solid waste programs.

\section{The Scientific Advisory Council and NEPA}

During the late 1960s, President Lyndon Johnson's Scientific Advisory Council directed a 3-year, multi-agency study on the national problem of solid waste. The Council's National Survey of Community Solid Waste Practices (Black et al. 1968) was the first (and thus far the only) study of its kind in the twentieth century. Since then, the government has compiled only limited national statistics on waste composition and management.

NEPA set forth a national environmental policy and created the Council of Environmental Quality within the Executive Office of the President. The act gave the council regulatory authority as well as responsibility for supervising national policy with respect to solid waste generation, disposal, and reuse. The council promulgated regulations in 1979 governing the NEPA process for all federal agencies. After more than 25 years, the council still formulates and recommends to the President national policies to protect environmental quality. However, the council has had little impact on solid waste issues, according to Hickman (1995-1997).

\section{The Clean Air Act}

Congress enacted two new laws in 1970 that affected solid waste management: the RCRA, and the Clean Air Act. The 1970 Clean Air Act gave the federal government broad regulatory powers to protect air quality. The law made protecting health the basis for regulating air emissions and clearly indicated that polluting industries would have to close or meet emission standards that were beyond the capacity of most technologies. Thanks to the law, air pollution problems stopped getting worse after the early 1970s. It was so effective that few people today realize it was not the original clean air legislation. Levy (1995) describes the impact of this legislation on air pollution from MSW incinerators:

There were about 300 solid waste incinerators in 1968. By about 1975, almost all of them were shut down. The designs were so bad that there was nothing you could do. Most of the 20 or 30 of them that stayed open had newer designs using the same electrostatic precipitator technology that was starting to be used on power plants.

In the 1970s, they started building new incinerators with electrostatic precipitators, and that's it. The controls were crude. They only controlled what they could measure, and they could only measure particulates. They didn't even know there was stuff like dioxins, because they didn't have the technology to detect them. 
As amended in 1977 and again in 1990, the Clean Air Act had a tremendous impact on incinerators, electric utilities, and other industries that generated significant air emissions. Under its auspices, EPA issued landfill emissions regulations and comprehensive air-emissions standards for municipal waste-to-energy facilities.

The Clean Air Act created an elaborate technology-based control program for toxic air pollutants from solid waste combustion. States were required to regulate emissions sources within their jurisdiction to ensure enforcement of the national technology-based emission limits. EPA was given the authority to define and enforce such limitations until state programs were approved.

Twenty years after it became law, the Clean Air Act resulted in solid waste being designated as a renewable energy resource. When EPA issued its acid rain rule under the 1990 Clean Air Act amendments, it included waste-to-energy plants in a list of "renewable energy generation facilities." The DOE 1990-1991 National Energy Strategy also recognized waste combustion as a source of renewable energy. The European Union issued similar rules recognizing solid waste as a renewable resource.

\section{The Resource Recovery Act}

The 1970 Resource Recovery Act amended and reauthorized the Solid Waste Disposal Act. Most importantly, it reaffirmed a federal role in solid waste management. The act continued programs authorized by the Solid Waste Disposal Act, but shifted its emphasis from disposal to recycling, materials recovery, and waste-to-energy conversion. The act called for a study of manufacturing and packaging to see whether solid waste generation could be reduced. It authorized a federal grant program for the development and implementation of new solid waste technologies. It also mandated the creation of guidelines for solid waste collection, transport, separation, recovery, and disposal.

Congress intended for the Resource Recovery Act to foster improved landfill practices, but the law was ineffective because it did not provide regulatory authority over solid waste management. Nor did it provide significant funding for the development of better landfilling methods. Hickman (1995-1997) describes what the law accomplished:

The Resource Recovery Act of 1970 added a demonstration grant program for silver bullet machines to make trash go away. Because it brought resource recovery into the program, we began working on waste-to-energy, recycling, and composting. The law also required a study of industrial and chemical wastes to see if they represented a significant problem.

That study led to the current hazardous waste program. That was important because we needed something to deal with the illegal practices of the midnight dumpers. The program had a lot of training, technical assistance, efforts to improve landfill practices, and a whole host of things to try and help states and local governments improve solid waste disposal practices.

The Solid Waste Disposal Act, as amended by the Resource Recovery Act, led to the creation of solid waste management programs in 48 states by 1975. Thirty-eight states also developed resource recovery programs, including plans for developing waste-to-energy facilities with federal assistance. The pioneering legislation remained in effect until the passage of RCRA. 


\section{Environmental Legislation in the 1970s}

Congress passed two environmental laws relevant to solid waste in 1972: (1) the Federal Water Pollution Control Act and (2) the Marine Protection Research and Sanctuaries Act. The nonregulatory Marine Protection Research and Sanctuaries Act attempted to curtail ocean dumping, but met with little success.

The 1972 Federal Water Pollution Control Act created a comprehensive program to protect and enhance the nation's ground and surface waters. Under the statute, EPA was responsible for setting effluent standards on an industry-by-industry basis. The agency was required to set the standards based on the availability and cost of pollution control technology. In 1977, Congress amended the act, renaming it the Clean Water Act. The revised law focused on technology-based standards as a method for controlling toxic pollutants. Congress amended the act once again in 1987, allowing EPA to set discharge standards above technology-based minimums.

Both the Clean Water Act and the Marine Protection Act increased pressure to dispose of waste on land, which, in turn, enlarged the threat of groundwater contamination from sanitary landfilling. Because the Clean Water Act did not specifically include aquifers as one of the "waters of the United States," the law did not give EPA authority to regulate pollutants created inside a landfill. Once Congress gave EPA regulatory authority over solid waste in 1976, however, solid waste management technologies and methods were required to operate in accordance with the provisions of these laws.

Following the 1973 energy crisis and the Arab oil embargo, Congress passed the Energy Reorganization Act of 1974. The act split the Atomic Energy Commission (AEC) into the Nuclear Regulatory Commission (NRC) and ERDA, in order to keep the AEC from both regulating the nuclear power industry and doing research and development for the same industry. The potential conflict in such an arrangement remains an issue today with EPA.

ERDA was the forerunner to DOE, created by Congress in 1977. The ERDA/DOE mission included developing domestic energy resources, including solid waste, to enhance the nation's energy security. The 1974 Non-Nuclear Energy Research and Development Act mandated federal research on the productive use of solid waste.

\section{The Resource Conservation and Recovery Act}

In 1976, Congress enacted RCRA, which established a comprehensive federal involvement in solid waste management that included regulatory authority for the first time. The intent of the legislation was to improve solid waste management by discouraging open dumping and encouraging the development of technologies to recover materials and energy from solid waste. RCRA stated that MSW management methods should be "environmentally sound and maximize the utilization of valuable resources including energy and materials which are recoverable from solid waste." 12 Because the law was designed to improve solid waste management practices, it did not address serious problems with closed or abandoned dumps.

By broadly defining waste, RCRA gave the federal government jurisdiction over virtually any waste, regardless of its physical form. It divided waste into two categories: hazardous and nonhazardous. Nonhazardous waste included MSW. Since the law was passed, the federal government has focused efforts primarily on the regulation of hazardous waste. As a result, RCRA

12 The Resource Conservation and Recovery Act, Public Law 94-580 (1976). Subchapter IV, Section 4001. 
never led to the sweeping changes in solid waste management that its authors envisioned. Hickman (1995-1997) explains that EPA declined to implement many provisions of the law:

RCRA was a very broad-based, very powerful piece of legislation that EPA has never fully exploited. I was involved heavily in the writing of that bill. We had the Clean Air Act and the Clean Water Act, and this bill was supposed to close the circle. RCRA had the authority to close the circle, with regulations, technical assistance, research, state program development - a complete package.

RCRA had a whole host of provisions that have never been used-technical assistance, support to states, citizen lawsuits, and so forth. EPA's investment has always been in the hazardous waste provisions. EPA abandoned MSW until it was forced to address it by the HSWA amendments [the Hazardous and Solid Waste Amendments of 1984]. I left the agency in 1978 and EPA essentially walked away from MSW in 1979. To this day, they don't do much with municipal solid waste.

Subchapter IV D of RCRA, which is usually called Subtitle D, gave the federal government authority over solid waste landfills and mandated regulation of solid waste disposal. It directed EPA to develop criteria for distinguishing sanitary landfills from open dumps. RCRA sealed the fate of open dumping near the nation's large cities, but had less impact on rural areas, according to Levy (1995): "If you go farther away from cities or if you go to Wyoming, or Utah, or Nevada, you will probably discover they continued open-burning right up into the 1980s. And most small towns in Alaska open-burn today. They have no alternative. The ground is frozen most of the year so they can't bury their waste. If they didn't burn it, bears and wolves would come down and rummage through it and cause problems."

RCRA provided federal aid to states and municipalities for solid waste management planning and resource recovery. Subtitle D encouraged states to develop solid waste management plans, then offered them technical and financial assistance to implement the plans. Most state plans described the amount and composition of their solid waste, the use of specific management methods, variations in solid waste management methods used by different local governments, and problem areas in solid waste management. By the late 1980s, many state plans included the goal of integrated waste management, a comprehensive and unified approach to managing solid waste. Because federal funding for state solid waste planning disappeared in 1981, not all state plans were formally approved by EPA.

By design, RCRA avoided preempting the responsibility of states for regulating solid waste. The single exception was importing or exporting waste. Because of a well-established federal role in regulating interstate commerce, states were not allowed to impose bans on importing or exporting waste for storage, treatment, or disposal.

RCRA set in motion a chain of events that forever changed solid waste management in the United States. Before the law was passed, solid waste problems had been seen in terms of poor disposal practices. After RCRA, solid waste became a management issue with major economic implications. The forced closure of open dumps and the regulation of landfills redirected municipal waste management on an unprecedented scale. In less than a decade, nearly two-thirds of the nation's landfills closed. During the same period, materials and energy recovery were introduced as important solid waste management options. 
RCRA sought to establish a major solid waste research initiative at EPA. It outlined specific topics for study, including glass and plastic, tires, waste composition, small-scale and low technology, and front-end source separation. Unfortunately, RCRA's vision for federal MSW research was never implemented. Carlton Wiles (1995-1997), formerly of EPA, describes what occurred: "EPA never evidenced any real commitment to funding an MSW research program. The actual money allocated to MSW research was nowhere near the amount authorized and appropriated. The money always got siphoned off somewhere else. I have no idea how the agency got away with that."

RCRA charged EPA with gathering information about how to reduce the amount of solid waste generated, about markets for materials and energy recovered from waste, and about solid waste management methods and costs. EPA was also supposed to develop a list of research projects for solid waste management. As part of this effort, EPA was to develop a library of solid waste management and resource recovery technologies and methods. This library of information was to be made available to states, communities, and businesses.

Under RCRA, the Bureau of Mines studied technical and economic issues related to the recovery of materials from solid waste. The Department of the Treasury looked at the impact of tax subsidies for specific materials on recycling. The Interstate Commerce Commission studied the relationship between freight rates and recycling. Due to budget cuts, much of this activity came to a halt during the early 1980 s.

\section{The Need for a National Solid Waste Policy}

Despite a broad focus on solid waste management, RCRA did not articulate a national policy regarding solid waste. According to an Office of Technology Assessment report (Levinson 1989), Congress may have avoided doing this out of respect for the traditional roles of local and state governments in solid waste management. However, the lack of national goals for solid waste management made it difficult to garner consistent support for solid waste programs at the federal level. As a result, federal efforts to solve solid waste problems have been somewhat uneven and fragmented. As Alter (1995) explains "There is no strategy about where we want to go. As it says in the Koran, if you don't know where you're going, any road will get you there. For a long time, we've needed to spell out what we want versus what can be done."

RCRA's failure to address a national solid waste policy reinforced a long-standing pattern of ignoring solid waste problems for as long as possible. Because politicians, policy makers, and federal agencies alternately espoused solid waste issues, then dropped them when something else appeared to be more important, it has been difficult to realize long-term benefits from the federal MSW program. For more than 30 years, funds have appeared during a real or imagined crisis, only to dwindle or disappear when public concerns subsided. The on-again, off-again federal MSW program has mirrored public attitudes toward solid waste.

The fate of solid waste research at EPA and DOE is illustrative. To underscore its desire that EPA comply fully with its solid waste directives, Congress directed EPA to move its Office of Solid Waste from Cincinnati, Ohio, to agency headquarters in Washington, D.C. Even so, EPA's Office of Solid Waste continued to divert research funding from solid waste to hazardous waste. EPA terminated MSW research altogether in 1979 in response to the discovery of chemical contamination in Love Canal, New York; Times Beach, Missouri; and other communities. Levy (1995) describes the rationale for this decision: 
Love Canal was 1978. All of a sudden we had to face hazardous waste, a problem that we didn't have solutions for. We didn't know how much was out there, we didn't know where it was. We didn't know which kinds were causing problems. We had no idea. So EPA said, we don't need all these people focusing on municipal solid waste. Put them to work on hazardous waste. It was a national problem and cleanup was a nightmare. So all of a sudden, our resources went to hazardous waste. We turned our back on MSW because we had solved it.

In the early 1980s, a significant portion of the federal solid waste research program, most demonstration projects, and grants to states for resource recovery, ended. Although some of this money was diverted to the cleanup of hazardous waste, the reduction also came in response to the Reagan administration's decision to withdraw support for research on alternative energy technologies.

After reviving its solid waste research effort in the late 1980s, EPA once again ended solid waste research in 1993. Four years later, DOE abolished its MSW program after supporting it for more than 20 years. The termination of the federal MSW research program occurred during a period of relative quiet on the garbage front. However, the fact that MSW was "out of sight, out of mind" did not mean that the nation no longer needed new and better waste management technologies.

\section{Hazardous and Solid Waste Amendments to RCRA}

Congress passed the Hazardous and Solid Waste Amendments to RCRA in 1984. HSWA clarified RCRA's opening dumping ban and directed EPA to evaluate whether federal and state regulations for solid waste management facilities were adequate to protect the environment and human health. HSWA allowed EPA to force states to implement permitting programs for landfills that accepted household or other hazardous waste.

HSWA defined waste minimization as an integral part of solid waste management for the first time. It also gave EPA the authority to directly manage a state's solid waste management plan. Local and state governments retained responsibility for implementing the plans, however. Under the auspices of RCRA as amended by HSWA, EPA was required to set minimum standards for landfilling. These minimum requirements included installing monitoring systems to detect groundwater contamination, undertaking corrective action if contamination was detected, and meeting basic standards for facility siting and care. Failure to comply with these requirements resulted in a facility being classified as an open dump. Disposal of solid waste in an open dump was prohibited.

The operation of landfills could be modified to meet the new landfill requirements. For example, the law forbid landfills from accepting liquid waste and mandated that they be retrofitted with liners and leachate collection systems. Comprehensive Subtitle D regulations, entitled Criteria for Municipal Solid Waste Landfills, were promulgated in 1991. States were given responsibility for enforcing the new rules and closing open dumps. Although EPA was not given the authority to take action against violators or states that failed to close open dumps, most of them soon closed anyway.

\section{Attempts to Reauthorize RCRA}

In 1989, Congress periodically began considering a reauthorization of RCRA, but a comprehensive reauthorization has not yet occurred. Several factors may be responsible: There has been no crisis to focus attention on solid waste since 1987. Other environmental issues have been considered more urgent than solid waste management. And solid waste has found few champions 
in today's climate of budget cutting and government downsizing. Hickman (1995-1997) suggests that industry may have played a role in shifting Congress's attention away from RCRA:

Several years ago, we were having a big debate about reauthorizing RCRA. As long as all we were talking about were federal mandates on how much solid waste local governments should divert from the solid waste stream, whether to place minimum content requirements for secondary materials, or how much secondary fiber would go into newsprint, the only people who cared were local governments and users of secondary materials. But, when they started talking about how maybe we should address the nation's materials use policy, all of a sudden American industry started to pay attention. The RCRA reauthorization disappeared in a heartbeat.

\section{Laws Promoting Energy Recovery}

Two laws passed in 1978 supported energy recovery from waste. The PURPA expanded the federal commitment to the use of alternative energy resources, including solid waste. The law required the Federal Regulatory Commission to guarantee markets for electricity generated by small power producers, including waste-to-energy combustion facilities. The commission complied by requiring electric utilities to buy electricity from qualified small power producers. To be "qualified," facilities had to use renewable resources and produce less than 80 megawatts (MW) of power. PURPA's intent was to decrease the nation's dependence on foreign oil and fossil fuels by diversifying energy production. It was instrumental in fostering the growth of the U.S. waste-toenergy industry during the 1980s.

The Department of Energy Act of 1977 established DOE and gave the new department the authority to award grants, contracts, price supports, and loan guarantees for waste-to-energy demonstration projects. The law also supported waste-to-energy research and development and authorized an evaluation of the performance and costs of facilities.

\section{Solid Waste Legislation: 1980-1992}

During the 1980s, Congress enacted four laws impacting solid waste management. The first of these, the 1980 Energy Security Act, was designed to reduce the nation's dependence on foreign oil. It gave the secretary of energy authority to provide loans for new waste-to-energy facilities and established an accelerated research, development, and commercialization program. The law provided funding for loan guarantees and price support loans for waste-to-energy facilities. Although funding for these purposes was withdrawn in 1982, public and private initiatives to develop new facilities continued throughout the rest of the decade, thanks to PURPA's market guarantees and provisions of the 1986 Tax Reform Act, which made waste-to-energy facilities eligible for federal tax credits through the 1980 s.

The 1980 Comprehensive Environmental Response, Compensation and Liability Act, also known as Superfund, provided funding and federal enforcement for cleaning up disposal sites contaminated with hazardous waste. The Superfund legislation contributed to EPA's decision to focus its attention on hazardous waste to the virtual exclusion of solid waste for nearly a decade. However, many older landfills, which had accepted sewage sludge or toxic industrial waste along with MSW, were declared as Superfund sites.

Congress enacted the 1988 Ocean Dumping Ban Act, successfully amending the 1972 Marine Protection Research and Sanctuaries Act. The new and tougher law mandated an end to ocean dumping of municipal, industrial, and commercial waste. Ocean dumping of sewage sludge was also 
banned except for sludge from the New York City area. ${ }^{13}$ The poor management of ocean dumping had convinced the public that both people's health and the environment were at risk from such practices. $^{14}$

The most recent congressional action impacting solid waste management was the 1992 Energy Policy Act (EPAct), which recommended the development and demonstration of refusederived fuel ${ }^{15}$ (RDF) for co-firing with coal in industry boilers and utility boilers. EPAct mandated the continuation of DOE's RDF research program, which began in the 1970s.

In 1995, the President's National Science and Technology Council (April 1995) took a step toward articulating a national policy on solid waste management. The council worked with representatives from the White House, DOE, other federal agencies, private industry, and others to develop a national environmental technology strategy. The strategy presented a vision for the future and the role environmental technology could play in shaping that future. It envisioned the creation of sustainable communities that would use advanced technologies to efficiently use raw materials, then recycle waste materials, or convert them to energy rather than simply discarding them.

\section{Regulation of Municipal Solid Waste}

Environmental laws may empower a federal agency to develop and promulgate regulations. For example, solid waste regulations for landfills and waste-to-energy facilities were developed by EPA under the auspices of RCRA and the Clean Air Act. The President can also give a federal agency the authority to promulgate regulations through an Executive Order.

Rule-making is a three-step process: First, the agency drafting the regulations publishes proposed regulations in the Federal Register. The public has the opportunity to comment on them, either by submitting written comments or through public hearings. If it wishes to do so, the agency can choose to revise the regulations, taking public comment into account. After the new regulations are written and approved by the agency, they are reviewed by the Office of Management and Budget $(\mathrm{OMB})$. After the agency incorporates changes recommended by OMB, it publishes final regulations in the Federal Register. Once regulations go into effect, they have the full force of law.

If regulations are violated, regulatory agencies such as EPA have several options. They can:

- Do nothing.

- Generate widespread publicity regarding the infraction.

- Revoke permits or refuse to renew expiring permits.

- Initiate administrative penalty proceedings aimed at obtaining corrective action, with small penalties.

- Request the Department of Justice to file civil suits for significant monetary penalties or to obtain an injunction.

13 New York's exception for sewage sludge was terminated by law in 1991.

14 The negative perception of ocean dumping failed to take account of the fact marine life thrived near dumping sites, according to Don Walter, former manager of DOE's MSW program. Walter speculates that had eastern cities dumped their waste far enough offshore to avoid having them wash back to shore. Ocean dumping might well have been considered an ideal "out-of-sight, out-of-mind" waste management method.

15 The term refuse-derived fuels was coined in 1973 by Dr. Jerome Collins, formerly of DOE. 
- Instigate action through the Department of Justice against the violator and management personnel deemed responsible for the violation.

Individuals and nongovernmental organizations can also file suits to force compliance with governmental regulations. If successful, such suits can force violators to pay penalties to the federal treasury. All or part of the plaintiff's attorney's fees are paid by the government.

The federal government has provided most of the leverage in enforcing the nation's environmental laws. After the early 1980s, EPA steadily increased its enforcement of environmental regulations. In recent years, the agency has relied heavily on penalties imposed administratively. However, EPA underwent major budget cuts during 1995 and 1996. At that time, the agency announced major cutbacks in its enforcement of environmental regulations, including those governing waste-to-energy combustion and landfilling.

Two decades of government regulation have significantly improved solid waste management practices. As Gregg Easterbrook declared in his 1995 book A Moment on the Earth, "The extraordinary success of modern environmental protection is ... perhaps the best instance of government-led social progress in our age (p. xviii)," With respect to solid waste, government regulations have been responsible for closing open dumps, shutting down polluting municipal incinerators, and improving landfill practices. Thanks to federal regulation, today's solid waste combustion and landfilling methods are superior to even those used a decade ago.

\section{Waste-to-Energy Emissions}

Other than requiring rudimentary emissions controls, substantive regulation of emissions from solid waste disposal facilities was essentially ignored until the late 1970s. About that time, interest in improving solid waste management converged with concerns about meeting national ambient air quality standards. Under the auspices of the Clean Air Act, EPA studied regulatory actions to control air emissions from waste-to-energy combustors.

EPA issued emissions guidelines for large municipal waste combustors (with capacities of 225 tons or more per day) in February 1991. Soon afterward, the 1996 amendments to the Clean Air Act mandated an even more stringent regulatory program, and EPA began work on a new set of regulations. The amendments required EPA to regulate emissions from facilities producing 10 tons or more of any one pollutant in a year or 35 tons per year of any combination of pollutants. In addition, the amendments specified 189 pollutants subject to regulation, including metals such as cadmium, lead, and mercury, which had not been regulated up to that time. Separate emission guidelines and new source performance standards were issued for large municipal waste combustors (processing 250 tons per day or more) and small waste combustors (processing 40 to 250 tons per day or less).

EPA conducted a $\$ 5$ million testing program on emissions from waste-to-energy combustors and incinerators in conjunction with the new regulatory thrust. Some tests were conducted in cooperation with Environment Canada, which had undertaken its own multimillion dollar national incinerator testing and evaluation program.

EPA set emissions standards to reflect the maximum achievable control technology (MACT) for solid waste combustion. MACT standards meant that new facilities must control emissions at the level of the best currently available technology. MACT standards for extant facilities were somewhat less stringent, but still required that these plants meet standards achieved by the top $12 \%$ of similar operations. 
EPA issued final regulations in November 1995. The regulations took account of industry's concerns regarding the technical feasibility of meeting the proposed guidelines and standards. They were positively received by the waste-to-energy industry. The new regulations covered particulate matter, acid gases (sulfur dioxide and hydrogen chloride), nitrogen oxides, carbon monoxide, metals (lead, cadmium, and mercury), dioxin, and di-benzofurans. Known as the New Source Performance Standards, the standards apply to new facilities or facilities that underwent modification after the standards were proposed.

The standards include limits on specific emissions, requirements on monitoring emissions, performance standards for pollution control technology, and requirements for training and certifying operators. When the new regulations were promulgated, the 1991 regulations were withdrawn by EPA. States have 1 to 3 years to bring waste-to-energy facilities into compliance with the new regulations or shut them down.

Lanny Hickman (1995-1997) gave the new regulations a lukewarm endorsement: "We're not opposed to regulating emissions, but we are concerned about the lack of scientific basis for the current regulations. I don't view the rules as overwhelmingly bad, but I don't think the incinerators in this country are getting a fair shake. There are other combustion sources out there that represent far greater sources for certain pollutants."

\section{Landfill Emissions}

In March 1996, EPA issued new source performance standards for new landfills and guidelines for controlling gas emissions from existing landfills. In formulating the regulations, EPA considered the role of landfill gas in creating ozone near the earth's surface, the contribution of methane to global climate change, the health impacts of individual gases and odors, and the risk of fire or explosion. EPA estimated that methane emissions from 7,124 landfills operating in the United States in 1987 totaled about 15 million tons per year. Landfills also emitted an estimated 300,000 tons per year of other gases such as toluene and methylene chloride.

Due to the complexity of landfills, EPA regulated total landfill emissions rather than individual pollutants. Emissions controls must be installed if emissions of gases other than methane exceed 50 megagrams per year. Gas control systems must be capable of collecting gas from the entire landfill, minimizing the migration of gas outside the landfill, and destroying the collected gases. The new regulation emphasizes design guidance and performance standards rather than rigid prescriptive requirements. Because this approach allows EPA to control landfills with the highest emissions, it should be more cost effective than other options. It should also be relatively simple to understand and enforce. As with many other regulations, states are responsible for submitting plans for implementing the regulation to EPA for approval. Now that the new regulation has gone into effect, EPA estimates that fewer than $10 \%$ of the landfills operating today will be required to collect landfill gas. The regulation does not require landfills to recovery energy from the gas.

The 1990 amendments to the Clean Air Act require that facilities emitting any regulated pollutants obtain operating permits from EPA. Furthermore, if a facility is required to obtain an operating permit for even a single pollutant, all other emissions from the site are subject to regulation under the permit. If implemented, the permitting requirements could have a major impact on solid waste management. Solid waste combustors, recycling centers, materials recovery facilities, transfer stations, and landfills could all be subject to permitting requirements as well as any future regulations issued in conjunction with the permitting program.

\section{Requirements for Landfills}


In 1979, EPA complied with RCRA's directive to develop criteria for distinguishing sanitary landfills from open dumping by publishing the Criteria for Classification of Solid Waste Disposal Facilities and Practices. The document outlined the following general requirements for landfills:

- Landfills in a floodplain must not restrict water flow, reduce the floodplain's capacity to store water, or permit a washout of solid waste that could pose a risk to human beings, wildlife, water resources, or land.

- Landfill operations must not pose threats to any endangered species or its habitat.

- Landfill operations must not pollute the waters of the United States in violation of the Clean Water Act.

- Landfill operators are prohibited from contaminating drinking water supplies.

- Landfill operators must periodically cover waste to control disease.

- With the exception of agricultural and forestry residues, landfill operators may not burn solid waste.

- Landfill operators must control explosive gases, prevent fires, regulate access to human beings, and control waste that attract birds if the facility is located within 10,000 feet of an airport.

Any land disposal operation that failed to meet these criteria was considered an open dump under RCRA. The criteria applied to new and existing landfills.

The 1979 criteria were supplanted by comprehensive Subtitle D regulations issued by EPA on October 9, 1993. The new regulations established minimum landfill standards in six areas: location, operation, design, groundwater monitoring and protection, closure and postclosure care, and financial assurance. They applied to all landfills accepting MSW, whether or not they also accepted combustion ash or sewage sludge. They were designed to protect groundwater and prevent pollution from poorly designed and operated landfills.

Small landfills that accepted fewer than 20 tons per day of trash and were located in relatively dry climates were exempt from costly requirements to control the flow of water in and out of the facility. Tribes and states with EPA-approved waste management plans were given flexibility in meeting the requirements. Landfills that closed before the regulations went into effect were required to have a final cover as specified by the new regulations, but were otherwise exempt.

A brief summary of the Subtitle D regulations follows. Unless otherwise stated, the regulations apply to new, existing, and expanding landfills.

\section{Location}

Certain areas are restricted or banned. These include airports, floodplains, wetlands, and areas prone to earthquakes, mudslides, or other natural disasters. Landfills not meeting the new siting criteria were required to close by October 9, 1996.

AIRPORT SAFETY: Because landfills often attract birds, operators of landfills near airports are required to prove that birds pose no danger to aircraft. The Federal Aviation Administration 
(FAA) must be notified if a landfill is built or expanded within 5 miles of a public airport. FAA guidelines ban landfills within 10,000 feet of runways used by jet aircraft, within 5,000 feet of runways used by propeller-driven aircraft, and within 5 miles of any runway where birds pose a threat to aircraft.

FLOODPLAINS: Landfills may not be located in flood-prone areas unless the landfill is designed to withstand flooding and prevent a solid waste washout. By definition, a solid waste washout is hazardous to human health and to the environment.

WETLANDS: Landfills may not be located in wetlands that are important ecological resources. If a state with an EPA-approved plan wants to create a landfill in a wetland area, it must prove the facility will not pollute the area and that no alternative site is available. Landfill operation must not violate local, state, or federal laws. Landfill operators must also prove there will be no net loss of wetlands.

EARTHQUAKE-PRONE AREAS: Landfills may not be built in fault zones or other areas prone to earthquakes. Because earthquakes can release pollution from a landfill into the surrounding area, landfills may not be sited within 200 feet of a fault that has moved within the past 9,000 years. Liners, leachate collection systems, and surface-water control systems must be designed to resist maximum predicted earth motion at any site.

UNSTABLE AREAS: Landfills may not be built in areas prone to landslides, mudslides, or sinkholes. In general, landfills are prohibited in these areas unless their design includes methods for preserving the structural integrity of the landfill if earth movement occurs.

\section{Operation}

Regulations for landfill operations cover procedures for excluding hazardous waste, covering waste, controlling vermin, preventing the accumulation of explosive gases, prohibiting open burning, controlling public access, controlling rainwater entering and leaving the landfill, keeping liquids inside landfills to a minimum, protecting water quality, and keeping records.

KEEPING OUT HAZARDOUS WASTE: Landfill operators must develop and enforce programs to keep hazardous waste out of MSW landfills. At a minimum, landfill operators must randomly inspect incoming loads of solid waste, keep records of these inspections, train their staff to recognize hazardous waste, and notify state authorities or EPA if such waste is discovered.

CONTROLLING VERMIN: Waste must be covered at the end of each day to discourage rats, flies, mosquitoes, birds, and other animals attracted to landfills. The daily cover reduces fire danger, odor, litter, and (human) scavenging. Acceptable cover includes a layer of soil 6 inches deep or alternate cover materials such as crushed glass. States may also temporarily waive the cover requirement if weather conditions make compliance impractical.

CONTROLLING METHANE: All landfills must monitor methane. If emissions levels exceed $25 \%$ of the concentration known to be explosive, landfill operators must notify the proper authorities and develop a plan for solving the problem. ${ }^{16}$

\footnotetext{
${ }^{16}$ Clean Air Act regulations for MSW landfills, which were promulgated March 12, 1996, mandate that large landfills collect and control landfill gas emissions, either by flaring the gas or using it as fuel in a landfill-gas-to-energy system. About 300 existing landfills and 45 new facilities scheduled for completion by 2001 will be subject to the new regulations.
} 
CONTROLLING AIR EMISSIONS: Open burning of solid waste is prohibited in landfills. There are a few exceptions to this rule, including the burning of agricultural waste, land-clearing debris, diseased trees, and debris from emergency clean-up operations.

RESTRICTING ACCESS: Landfill operators must restrict the public's access to their facilities. This rule is intended to prevent illegal dumping and protect public health and safety.

PROTECTING WATER QUALITY: Landfills must have ditches and levees around them to keep storm water from flooding the facility and to control runoff. These structures must be designed to prevent pollutants from being swept into lakes or rivers during a severe storm lasting 24 hours. Landfills may not violate the Clean Water Act or other state and local laws protecting water quality. Leachate (the acidic liquid created inside a landfill) may be recirculated through a landfill only if the facility has a composite bottom and side liners.

RESTRICTING LIQUIDS: To minimize the amount and toxicity of leachate, landfills may not accept liquid waste from a tanker truck or in 55 -gallon drums.

RECORD KEEPING: Landfills must keep detailed records of siting restrictions; design information; inspections; training and notification procedures; monitoring, testing, and analytical data; and closure and postclosure plans.

\section{Design}

EPA sanitary landfill design regulations cover specific engineering requirements. The standards were written to ensure that landfills would not pollute drinking water. In states with EPAapproved plans, landfill owners can design landfills to local conditions. Otherwise, they must use an EPA design or get a waiver. EPA design standards apply to all new landfills and to expansions of existing landfills.

Landfill design standards require a composite liner with a leachate collection system. The liner must consist of a flexible membrane (plastic) liner at least 30 millimeters $(\mathrm{mm})$ thick placed on top of at least 60 centimeters $(\mathrm{cm})$ of compacted soil. If the upper liner is made of high-density polyethylene, it must be $60 \mathrm{~mm}$ thick. The composite liner forms a barrier that prevents leachate from escaping from the landfill into groundwater. New landfills must install a leachate collection system. Existing landfills were not required to add liners and leachate collection systems.

\section{Groundwater Monitoring and Protection}

Landfill operators are required to drill wells around the facility and sample the water twice each year for pollution. If contamination is discovered, operators must solve the problem. States were required to implement groundwater monitoring programs at existing landfills by 1994 at the latest. New landfills were required to have groundwater programs in place before accepting solid waste.

If testing reveals that pollution is occurring, landfill operators must initiate a much more extensive testing program within 90 days. The new program must test for 62 basic contaminants annually. If any are found, landfill operators must then test groundwater for 213 additional chemicals twice each year. If any contaminant is detected above specified levels, landfill operators must determine the nature and extent of any release from the landfill and fix the problem. If the release has migrated from the landfill, it is necessary to notify residents and owners of the affected property.

\section{Closure and Post-Closure Care}

Landfills must be closed in a way that prevents problems from developing later. They must be capped with a final cover designed to keep water out of the buried waste. Owners are required to 
maintain the final cover, monitor groundwater, collect landfill gas, and maintain the area for 30 years after closure.

The basic final landfill cover must be composed of two layers. The bottom layer should be at least 18 inches of clay or other impermeable material. The top layer should consist of at least 6 inches of soil capable of supporting plant growth.

\section{Financial Assurance}

Landfill owners must prove they can pay for landfill closure, maintenance, and cleanup. The requirement can be met by establishing a trust fund, posting a surety bond, passing a corporate financial test, or obtaining an insurance policy, a corporate or government guarantee, or letter of credit. To date, this provision has been very loosely enforced, according to Lanny Hickman (1995-1997), who believes the financial assurance provisions are the most important piece of the Subtitle D regulations and should be more carefully implemented than currently practiced:

EPA finally got around to issuing their landfill regulations, and they're implementing them in a way that's going to totally screw up. The most important provisions of the regulations are the financial assurance provisions - the requirement that permit holders put money aside to compensate people for any later damage from contamination beyond the boundaries.

EPA, for whatever reason, is allowing a whole series of criteria such as net worth for demonstrating financial assurance. Net worth is absolutely useless, whether it's a private or public landfill. They're talking about letting local governments demonstrate their bond rating. What the hell does that mean? That's not money in the bank! The only thing I think makes any sense for a landfill financial assurance package is what we call a trust fund - money paid into a fund dedicated to that site. That's what we support: making the landfill owner create a trust fund sufficient to fix whatever happens.

\section{Clean Water Regulations}

Until 1990, the Clean Water Act influenced solid waste management indirectly through permitting requirements. Facilities releasing wastewater into the environment were required to obtain permits for these discharges. In 1990, EPA began requiring similar permits for storm water discharges from structures that carried storm runoff, snow melt, or drainage. Such structures must now comply with the best available technology or the best control technology under the Clean Water Act. The new regulations cover solid waste haulers, materials recycling facilities, landfills, and waste-to-energy plants. Unless these entities discharge their runoff to a sewage treatment facility or do not have a structure to manage runoff, they are now regulated.

\section{Research and Development}

The federal MSW program made important contributions to the scientific understanding of solid waste management methods and to the development of new solid waste technologies. Since the mid-1960s, the U.S. Public Health Service, TVA, the U.S. Bureau of Mines, the National Institute of Standards and Technology (formerly the National Bureau of Standards), EPA, ERDA, and DOE have conducted solid waste research. ERDA and DOE focused on the development of 
technologies to recover energy from solid waste. The federal MSW research program on specific solid waste management technologies and methods is described in Chapters 4-8.

\section{Agencies Responsible for Municipal Solid Waste Programs}

Since 1965, seven federal agencies, two national laboratories, and one cabinet-level department have directed different aspects of the federal MSW program. At times, these entities have worked closely together. Less often, federal programs have been conducted independently of one another. This section briefly describes the organizations responsible for the federal solid waste programs of the past 30 years.

\section{U.S. Public Health Service}

The U.S. Public Health Service was established by an act of Congress on July 16, 1798. Its original mission was to set up hospitals for the care of U.S. merchant seamen. Over the years, Congress greatly broadened the scope of the U.S. Public Health Service. In July 1944, Congress passed the Public Health Service Act, which consolidated and revised all existing legislation affecting the agency. The agency's responsibilities have expanded since then.

When the 1965 Solid Waste Disposal Act provided funding for additional solid waste research, the U.S. Public Health Service performed or sponsored much of this research until 1971 when EPA assumed responsibility for solid waste programs. During the late 1960s, the agency's research laboratory in Cincinnati, Ohio, investigated MSW processing and separation, the recovery of energy and materials, anaerobic digestion, the conversion of cellulosic material to alcohol, and landfill practices.

The U.S. Public Health Service's program became the nucleus of an expanded federal program that changed the face of solid waste management in the United States. Hickman (1995-1997) recalls the excitement of helping to create a new solid waste program:

The foundation of the solid waste program in this country today was 25 young men whom we hired and brought on duty during the 1960s. The process of selection was so rigorous that we hired almost no one who didn't have a master's degree and hadn't graduated in the top $10 \%$ of their class. We hired the cream of the young engineering crop from some of the best schools in the country.

It was a wonderful time [1965-1970]. Most of the young people we brought in have stayed in the field. I view this as testimony to the success of the [Solid Waste Disposal] Act and the Public Health Service system.

The U.S. Public Health Service, currently part of the Department of Health and Human Services, is charged with protecting the public health and with advancing the nation's physical and mental health. The U.S. Public Health Service works with states to set and implement national health policy. It also conducts research, develops health resources, and promulgates regulations to protect public health. U.S. Public Health Service agencies include the National Institutes of Health, the Centers for Disease Control, and the Food and Drug Administration.

\section{Tennessee Valley Authority}

Congress established TVA as a federal agency in 1933 to control flooding, improve navigation, replenish soil, promote improved agricultural practices, and produce electrical power for 
the Tennessee Valley. During the 1930s and 1940s, TVA built dams along the Tennessee River that protected vast areas from flooding and provided substantial amounts of hydroelectric power. Today, TVA is the nation's single largest producer of electricity, providing power to more than seven million people in seven states. The agency operates five nuclear power facilities, 11 coal-fired generation plants, and 29 hydroelectric facilities.

Since 1965, TVA has sponsored MSW research and development. During the late 1960s and early 1970s, the agency co-sponsored a composting research project in Johnson City, Tennessee. More recently, it sponsored a demonstration of using compost from MSW on crops and investigated the reclamation of strip mines. The agency also evaluated waste-to-energy facilities and developed a chemical process for making alcohol fuels from MSW.

TVA scientists and engineers continue to investigate air quality issues, develop new strategies for protecting watersheds, and develop innovative solid waste treatment techniques.

\section{U.S. Bureau of Mines}

Congress established the U.S. Bureau of Mines on January 1, 1910. The bureau was both a research and a fact-finding agency. As part of its mission, it studied environmental problems associated with minerals. The bureau investigated cost-effective technologies for extracting, processing, using, and recycling mineral resources. In this context, the bureau studied methods for recovering materials from solid waste and combustion ash. It also investigated methods for stabilizing and recycling combustion ash. Congress dismantled the agency in January 1996.

\section{National Institute of Standards and Technology}

The National Institute of Standards and Technology was founded in 1901 as the National Bureau of Standards. It was renamed in 1988. The institute helps industry develop technologies to improve product quality, modernize manufacturing processes, and ensure product reliability. It also disseminates measurements, standards, and new scientific discoveries to industry to aid in the commercialization of new products. As part of its measurement program, the institute developed instruments to measure the energy content of solid waste. The institute assisted the American Society for Testing and Materials in developing consensus standards for the analysis and processing of MSW.

\section{U.S. Environmental Protection Agency}

Congress established EPA in December 1970 as an independent agency within the executive branch. EPA brought together environmental activities from other federal agencies, including the U.S. Public Health Service's solid waste research program and the Bureau of Solid Waste Management. The Bureau of Solid Waste Management formed the nucleus of EPA's Office of Solid Waste, which was created to implement the 1970 Resource Recovery Act. Hickman (1995-1997) recalls the early days with the newly formed Office of Solid Waste:

The Office of Solid Waste had a reputation of being very independent and noncooperative with the EPA bureaucracy. We just took the position that we were unique and elite. We were not a regulatory body. We had a strong partnership with state and local officials, and we just did our own thing. We had a fair amount of autonomy until 1976 after RCRA was passed. RCRA changed the whole history and direction of the office because it brought us into the regulatory arena. 
EPA is responsible for executing the nation's environmental laws, including the Clean Air Act, the Clean Water Act, RCRA, the CERCLA, and HSWA. A major part of EPA's mission is to prevent, reduce, and control pollution through research, monitoring, regulation, and enforcement. EPA also supports environmental activities sponsored by state and local governments, nongovernmental organizations, business, individuals, schools, and universities. The agency operates 10 regional offices, which cooperate with state and local governments to ensure the implementation and enforcement of federal environmental laws.

Under the provisions of the 1970 Resource Recovery Act, EPA conducted solid waste research and demonstration programs, including several resource recovery demonstration projects. EPA also sponsored studies of resource recovery methods, source reduction methods, and ways to provide incentives to encourage the recycling of waste. Congress directed EPA to publish guidelines for responsible collection, separation, recovery, and disposal of solid waste. The intent of the voluntary guidelines was to better protect public health and the environment. The agency also took responsibility for efforts to stop open dumping.

Beginning in 1971, EPA provided funds to states for solid waste planning. Grants were also given to state and local agencies to conduct surveys of existing disposal practices and problems, to develop strategies for collecting and recycling abandoned automobiles, and to determine the feasibility of constructing new waste-to-energy systems or improved landfills.

Despite public and congressional support for a federal solid waste program, EPA proposed a drastic cutback in its solid waste program in 1973. The agency recommended eliminating both planning grants and technology demonstrations. It also suggested reducing solid waste research and technical assistance to states. The agency argued that federal activities be limited to the regulation of hazardous waste. NREL's Carlton Wiles (1995-1997) recalls:

Sandy Hale [head of EPA's Office of Solid Waste] put forward the policy that no additional technology was needed to solve the MSW problem. He moved his division to Washington, D.C., leaving the research division in Cincinnati. The R\&D program had a big budget cut, and EPA's Cincinnati lab had to stop doing in-house work. After that, they used their budget to support extramural research, mainly in universities.

Public outcry forced EPA to amend this position, but EPA consistently spent less on solid waste research than Congress appropriated for it during both the Nixon and Ford administrations. Hickman (1995-1997) describes this turbulent period:

EPA's solid waste program had had big budget cuts in 1973 and 1974. That's when we closed [the Office of Solid Waste] in Cincinnati down. It was a very difficult, acrimonious time for the federal program. Why? Because we were a nonregulatory program in a regulatory agency, and [Nixon administration appointees] said that since solid waste was a state and local government responsibility, why do we need a federal program? You have no oversight, no responsibility except to provide assistance, and that's not what EPA is in business to do. We were able to keep a small office together in Washington, D.C., with the expansion of a hazardous waste initiative. 
During the 1970s, EPA conducted research on land disposal, waste-to-energy conversion, and recycling technologies. Most of these efforts were abandoned in the late 1970s when the agency turned its attention to regulating hazardous waste.

EPA's desire to end its solid waste program was revisited successfully during the early 1980s and again in 1993. The agency faced intense deadlines and pressures for regulatory action from Congress and environmental groups during the 1980s. After 1981, MSW research at EPA occurred strictly in the context of regulatory development. Wiles (1995-1997) recalls:

Our last research symposium on resource recovery, held in Philadelphia in 1981, marked the end of the EPA MSW and resource recovery program. After that, the program turned to supporting the Office of Solid Waste by providing research to fill data gaps in the development of regulations for hazardous waste.

I thought the agency made a huge mistake in not providing enough funding to maintain a core of MSW expertise. I believed that eventually hazardous waste would be brought under control, and the cities were still going to have big problems with their MSW. Ironically, we were asked eight years later what needed to be done in the MSW area, and we'd been out of it all that time.

By the end of the 1980s, EPA had developed a strong constituency in the nation's environmental groups and had isolated itself from the regulated community. Hickman (1995-1997) explains:

By 1978, the agency was taking steps to isolate itself from any constituency in the regulated community. As a result, there's no commitment to serve a client base. The commitment is to satisfy the management of the organization and to enforce. The old federal-state-local-industry partnership disappeared, because the regulatory role made it very difficult to maintain.

EPA has become a totally politicized agency. It's not an agency based on science and technology. It's an agency based upon what is politically expedient. The politics became significant when the Reagan administration came in. Environmental groups became very powerful on the Hill. And, legislation drives EPA.

In 1988, a successful lawsuit brought by the Environmental Defense Fund and others forced EPA to resume its efforts to regulate solid waste management and develop better land-disposal methods. The lawsuit claimed the agency had ignored congressional directives to develop landfilling regulations. For the next 5 years, the agency led national efforts to promote environmentally sound solid waste management. Intensive regulatory efforts resulted in new air emissions standards for solid waste combustion and Subtitle D landfill regulations in 1991. EPA issued more stringent air emissions standards in 1995.

During the late 1980s, EPA worked with individuals, businesses, environmental groups, and other government agencies to develop a comprehensive national plan for solid waste management. The agency published its findings in The Solid Waste Dilemma: An Agenda for Action in 1989. The document outlined a strategy for addressing the nation's solid waste management issues, including establishing a solid waste management hierarchy of (1) waste minimization, (2) reuse and recycling, (3) combustion with energy recovery, and (4) the use of landfills. 
Since the publication of Agenda for Action, there has been debate about whether EPA intended solid waste management professionals to strictly adhere to its hierarchy of four basic waste management methods. Some argued that the hierarchy simply represented a good general philosophy of waste management. Regardless of EPA's initial intent, most professionals view the hierarchy not as a priority list but rather as a menu from which to select an integrated waste management system that will best serve the needs of a specific municipality or region.

Between 1989 and 1991, EPA and other federal agencies implemented programs to reduce waste production, recycle, and purchase recycled materials. These efforts were undertaken to spur the development of new markets for recycled products. Government planners believed that larger markets would foster manufacturing initiatives to make use of growing quantities of materials collected in curbside and drop-off recycling programs.

In 1991, EPA created an MSW technology section at the agency's Cincinnati laboratory. The program studied landfills as bioreactors, recycling, innovative waste management technologies, and combustion ash residues. It was working on developing technical criteria for using ash in an environmentally safe manner for such applications as roadbeds, construction blocks, and shore erosion control devices when it was disbanded in 1994.

In 1995, EPA conducted a minimal amount of MSW research, which was being phased out. With respect to solid waste, the agency focused on providing grants and technical assistance to encourage source reduction and recycling.

\section{Energy Research and Development Administration}

The Energy Reorganization Act of 1974 divided AEC into ERDA and NRC. ERDA began operation in January 1975 with the goal of bringing federal energy research and development within a single agency whose mission was to develop new energy technologies. The NRC was established to separate the licensing and regulation of nuclear power from the development and production of nuclear power and weapons.

As part of its mission, ERDA assumed responsibility for the solar energy research program, launched by the National Science Foundation in 1974. The establishment of ERDA came in the wake of a rapidly expanding federal commitment to developing a variety of energy production and conversion technologies, including energy recovery from waste, the sun, coal, and nuclear fission. The desire to develop these technologies came in response to oil price hikes and supply disruptions that accompanied the energy crisis of 1973.

In setting ERDA's research priorities, Congress affirmed its commitment to the development of a variety of energy production and conversion technologies. ERDA subsequently concentrated on technology development, with an emphasis on the construction of pilot and demonstration plants. The ERDA program was one of the first federal programs to recognize the need for time-consuming research and development as a prerequisite for technology demonstrations. Wiles (1995-1997) recalls ERDA's beginnings: "ERDA's statutory mandates [the Solar Energy Act and the NonNuclear Energy Research and Development Act] were almost identical to EPA's in terms of the authority to do resource recovery work. Of course, ERDA was to concentrate on energy recovery. ERDA got some new budget money, just as EPA's MSW research budget was being cut."

ERDA's technology development program focused on sophisticated hardware. As a result, it sometimes overlooked simpler and lower-cost options in favor of more sophisticated, complex systems. It preferentially funded research by large corporations, particularly in the aerospace industry. This led to an emphasis on large, sophisticated systems. The development of energy 
recovery technologies during the 1970 s reflected this bias. In contrast, the urban waste program focused on research to gain a better understanding of MSW processing systems.

Developing domestic energy resources was a top national priority during ERDA's brief existence. During 1976 and 1977, the agency oversaw the establishment of SERI in Golden, Colorado. Congress had mandated SERI's creation under the 1974 Solar Energy Research, Development, and Demonstration Act.

Donald K. Walter was hired in September 1975 to manage ERDA's MSW program and remained with ERDA and later DOE until 1994. One of the program's first projects was to evaluate energy consumption in various municipal services such as solid waste collection and wastewater treatment. The study found that municipal services consumed a relatively small part of the nation's annual energy budget. ${ }^{17}$ The results led ERDA to concentrate its efforts on recovering energy from solid waste.

Just days before he left office in January 1977, President Gerald Ford recommended the creation of a Department of Energy to Congress. Two months later, President Jimmy Carter formally reiterated the request. The department was established by the Department of Energy Organization Act on August 4, 1977, and was activated on October 1, 1977. ERDA ceased to exist when its programs were incorporated into the new energy department.

\section{U.S. Department of Energy}

The Department of Energy Organization Act of 1977 created a single, cabinet-level energy department by combining ERDA, the Federal Energy Administration, the Federal Power Commission and the Alaska, Bonneville, Southeastern, and Southwestern Power Administrations. DOE also assumed the power-marketing functions of the Bureau of Reclamation and energy-related activities of the Interstate Commerce Commission and the Departments of Commerce, Housing and Urban Development, the Navy, and the Interior. The department initially employed about 20,000 people and had a budget of $\$ 10.4$ billion. James Schlesinger was the first Secretary of Energy.

Since 1978, DOE has been responsible for marketing federal power, energy conservation, a nuclear weapons program, energy regulatory programs, energy data collection and analysis, and research and development of energy technologies. As part of its mission, DOE placed a major emphasis on the development and commercialization of solar, geothermal, waste-to-energy, and other technologies utilizing renewable energy systems.

During the late 1970s, DOE planned a comprehensive waste-to-energy program, but the program was never fully implemented. From 1978 to 1980, funding for the DOE MSW program increased steadily, and large waste-to-energy demonstrations were planned. DOE's initial 1981 MSW program budget totaled \$231 million, with \$215 million earmarked for technology demonstrations mandated by the Energy Security Act and \$16 million slated for research and development. In January 1981 when President Reagan took office, major changes occurred. Money for solid waste technology demonstrations was rescinded. DOE's MSW program budget fell to \$6.8 million. Table 3.2 summarizes MSW program budgets from 1975 to 1981.

17 Trash collection consumed less than .01 quads a year. Pumping and treating drinking water consumed less than 0.1 quads a year. About .5 quad per year was expended in treating wastewater. However, with proper management to recover methane, wastewater treatment could supply between .1 and .15 quads of energy. 
Table 3.2. ERDA/DOE MSW PROGRAM BUDGETS 1975-1981

(In millions of dollars)

\begin{tabular}{|c|c|c|c|c|cc|}
\hline 1975 & 1976 & 1977 & 1978 & 1979 & 1980 & $1981^{*}$ \\
\hline 1.5 & 4.65 & 4.8 & 13 & 17 & 10 & 6.8 \\
\hline
\end{tabular}

*Original budget of \$231 million reduced by Reagan administration

By 1983, the MSW program budget was only about $\$ 1$ million a year. DOE shifted its solar development activities away from costly demonstration and commercialization efforts, greatly impacting the MSW program. Ambitious technology demonstrations were supplanted by a modest, long-term, high-risk research and development program. Once the dust settled, MSW program budgets stabilized, but at a level comparable to ERDA's first year of operation. Don Walter (1994-1995) recalls this period of time: "We were not allowed to use the word demonstration, so we invented all sorts of words to replace it. If we wanted to do something near-term, we used words such as proof-of-concept, pilot plant, or engineering development facility. All these things were a step before an actual demonstration, which implies a full-scale, first-of-its-kind commercial operation."

DOE's MSW program received modest increases in funding under the Bush administration. Funding stayed level during the Clinton administration until 1996 when the MSW program lost support within DOE and was abolished. Program funding dropped to less than \$2 million in 1996, with funds earmarked for the completion of work on a high-solids anaerobic digestor and an orderly close-out of the program. In 1996, Congress also eliminated a 5-year program to address global climate change by recovering and using landfill gas. DOE's MSW program completed its activities in spring 1998. The termination of DOE's MSW program occurred during a period of relative quiet on the solid waste front. However, the fact that solid waste was "out-of-sight, out-of-mind" should not be construed to mean that the nation no longer needed new and better solid waste management technologies.

For 20 years, DOE's MSW program provided technical assistance and financial support to local governments, the solid waste management industry, and professional organizations such as the American Society of Mechanical Engineers (ASME) and APWA. Although the program's primary focus was energy recovery from waste, it also supported research and development of recycling, sewage treatment, and landfill gas-recovery technologies. The program sponsored RDF and methane gas research at Argonne National Laboratory, anaerobic digestion research at NREL, numerous industry technology development projects, and dozens of feasibility studies of waste-to-energy conversion, and other energy recovery technologies.

\section{Argonne National Laboratory}

Argonne National Laboratory was created by President Harry Truman's Executive Order on December 31, 1946. The laboratory came under the jurisdiction and sponsorship of the AEC and was operated by the University of Chicago. The laboratory was transferred to ERDA and subsequently to DOE during the 1970s. From 1977 to 1986, Argonne National Laboratory managed waste-toenergy research projects for DOE and provided program support for the national MSW program. Since 1986, Argonne scientists and engineers have continued research on RDF and landfill gas emissions. 


\section{National Renewable Energy Laboratory}

The 1974 Solar Energy Research, Development and Demonstration Act mandated the establishment of SERI, responsible for the development of solar energy technologies. SERI's mission was "to provide significant support to ERDA's solar energy program and to contribute to the establishment of a solar energy industrial base that will foster the widespread use of solar technology, thus creating a major alternative source of energy for the country." 18

SERI was created in 1978 under the aegis of DOE. Although waste-to-energy technologies were considered to be solar energy technologies, ERDA did not initially assign SERI responsibility for managing solid waste research, which was already under way at Argonne National Laboratory. The institute assumed responsibility for managing solid waste research and waste-to-energy technology development in 1986. In 1991, President George Bush made the institute a national laboratory, renaming it the National Renewable Energy Laboratory.

\section{Profile: Donald K. Walter}

Donald K. Walter managed the ERDA/DOE MSW program from its inception in 1975 to 1994 when he retired as director of the Office of Waste Reduction Technologies. Trained in civil engineering at Drexel University, Walter began his career in MSW management in the army. In 1970, Lt. Col. Walter served as the public works officer for four German cities with American military installations. His responsibilities included solid waste collection:

That's where one of my favorite stories comes from. At the time, the Germans used a very interesting truck. It was fully enclosed and it had an automatic loading system for their big, heavy trash cans. As it turned out, they charged for waste collection by the can. Every Monday morning, a Mercedes drove up to our housing area. The driver jumped out with his waste and dumped it in our cans so he didn't have to pay for it to be hauled off. We did.

Walter returned to the United States to become the facility engineer at Fort Detrick, Maryland. His waste management responsibilities included recycling, waste collection, and waste hauling to a nearby landfill. Fort Detrick also had its own sewage and water treatment plants. Walter recalled one of the more interesting aspects of his job at Fort Detrick:

I actually had an incinerator that was capable of burning an elephant. Fort Detrick was a biological warfare center, and the major piece was defensive. If, for example, we were out in the jungles of Africa, or in Southeast Asia, using elephants in a war for some reason and the enemy decided to attack the elephants with some sort of biological agent, what would it be? And what could you give the elephant to cure it? The idea was that we would have elephants at Fort Detrick that we would give specific diseases to and then cure them. Well, in doing this, you could kill an elephant. Or you might have one die of old age and now you have to get rid of an

\footnotetext{
${ }^{18}$ SERI's mission as stated in ERDA's Request for Proposal to establish and manage the institute.
} 
elephant. But what the hell do you do with an elephant? There aren't any elephant cemeteries around.

We never actually ended up incinerating any elephants. We did incinerate a lot of mice, rats, probably a few monkeys, and some dogs I don't know about, which were on the post and used for experiments. In fact, the post developed a vaccine for Venezuelan Equine Encephalitis. An outbreak moving through Texas was stopped because the vaccine was available at Fort Detrick. A story like this never gets told in the papers.

Walter left the army in 1973 to become the city engineer for Annapolis, Maryland. He held this position for 2 years before being selected to lead the MSW program at ERDA. He is well known for his Ten Commandments of MSW management:

I. Thou shalt have thy waste at thy disposal.

II. Thou shalt manage thy waste system.

III. Thou shalt not produce anything no one wants to buy.

IV. Thou shalt honor thy technology.

V. Thou shalt honor all thy environment.

VI. Thou shalt recognize and manage thy risks.

VII. Thou shalt dispose of thy residues.

VIII. Thou shalt not believe in total waste recovery.

IX. Thou shalt honor thy economics.

$\mathrm{X}$. Thou shalt not expect to find gold in thy garbage. 


\subsection{Minimizing the Waste Stream}

Source reduction is a natural economic phenomenon produced by competitive environments. ${ }^{19}$

Waste minimization, or source reduction, has to occur before people set their solid waste out for the trash collector. By the time the waste management professionals get involved, it is too late to find another use for the discards and minimize the amount of solid waste produced. Because it has potential for reducing the volume of solid waste, source reduction should be part of effective solid waste management. Don Walter (1994-1995), former MSW program manager at DOE explains: "Source reduction absolutely makes sense. Why? Two-thirds of the cost [of managing] MSW is in collecting it. There is absolutely no reason to produce waste to recycle it or use it as a fuel if you don't have to make it at all."

When most people think about solid waste, they think about where the waste ends up rather than where it comes from. Yet, the most effective method of minimizing solid waste is to create products that use fewer material and energy resources. This method must be implemented as part of producing new products and packaging. Merchandise can also be designed for longer life and greater durability, which delays the generation of solid waste. However, because even durable materials eventually end up as solid waste, this method is not as effective as using fewer material and energy resources initially. Another strategy for minimizing waste encourages consumers to reuse products rather than discarding them. Most successful efforts to minimize waste incorporate one or more of these three methods. ${ }^{20}$

Source reduction may have been practiced in prehistoric times. The ancient Maya, for example, curtailed the use of tools, ornamental ceramics, and body ornaments after 1200 A.D. They stopped burying their dead with pottery, tools, and jewelry that were still usable and substituted broken objects for new pottery and "fake" jewels made of clay beads covered with gold foil for gold jewelry. We do not know if the Maya intended to reduce their waste or if waste reduction was a byproduct of widespread economic decline.

The first U.S. source reduction initiatives took place in the 1980s. Most states debated bans on products and on disposal of certain products, and many legislated such bans. By 1990, 29 states and the District of Columbia had enacted about 100 bans. The most frequently targeted items were polystyrene (foam) products, drink boxes, plastic food packaging, and packaging that was not biodegradable. At the time, environmental groups, the public, and many officials believed that packaging made up a huge fraction of solid waste and was solely responsible for increased solid waste generation.

As recently as 1990, the assumption that packaging was inherently wasteful continued to go largely unchallenged. Harvey Alter (1995) explains why so many people believed packaging was responsible for the skyrocketing generation of solid waste:

${ }^{19}$ Alexander, Judd H. (1993). In Defense of Garbage. Westport, Connecticut, and London: Praeger, p. 93.

${ }^{20}$ One strategy for source reduction that enjoys little support would be laws requiring a reduction in the generation of specific consumer goods (for example, automobiles) by a set percentage of, say, $20 \%$. The economic cost of such a move in terms of lost revenues and unemployment could total billions of dollars, according to Judd Alexander (1993). Selecting a product for mandatory source reduction would be an impossible task for our distinctly nonhomogeneous society. Even the often maligned styrofoam coffee cups, disposable diapers, and drink boxes have ardent supporters among America's consumers. 
Lots of changes happened in this country after World War II, including packaging. People started to panic about [packaging increasing] MSW. When people got concerned about packaging, they neglected to look at other changes such as the demise of coal, the increase in reading material, the general increase in affluence, and our transformation into a consumer society. So far, we're only looking where the light is best—at packaging.

MSW grew at a faster rate than the U.S. population between 1985 and 1995. Population grew at $1 \%$, while MSW increased from $2.4 \%$ to $2.7 \%$ a year. During the same period, packaging grew at $1 \%$, but paper towels, office waste, junk mail, books, magazines, and other reading materials grew at $4.5 \%$. The use of disposable reading materials and paper products burgeoned - not the use of packaging.

In reality, packaging and microwave cooking have been responsible for reducing the amount of food waste in MSW in the past 30 years. Modern production methods, packaging, storage, and food distribution actually create less total solid waste than older methods did. The United States now has one of the lowest amounts of food waste in its solid waste of any country in the world. Thanks to packaging, food waste in the United States is half as high as in Mexico City, where residents have less access to processed, packaged foods (Rathje and Murphy 1992). Judd Alexander (1993) explains that, by content, $59 \%$ of all packaging is used for food and beverages. He says that people who have worked in packaging regard it not as an item, but as a system - part of a distribution system that confers huge benefits. In part because of packaging, U.S. citizens get the [cheapest] food in the world, too.

\section{Limits of Source Reduction}

Packaging makes up about 30\% of MSW (Alexander 1995). About half of this packaging, such as pallets and corrugated boxes, is used for shipping goods. Another $30 \%$ is used as containers for liquids such as soft drinks, milk, household cleaners, and so forth. The remaining $20 \%$, or $6 \%$ of total MSW, includes the merchandising packaging that is often the target of source reduction campaigns. However, even if this fraction of packaging were reduced by one-third, the generation of solid waste would fall by only about $2 \%$ - hardly a solution to the nation's solid waste management problems.

Although there is ample opportunity for reducing packaging, there are limits to what source reduction can achieve in terms of solid waste reduction - regardless of its political appeal (Rathje and Murphy 1992). Few people would be willing to jeopardize consumer safety and public health or send the economy into a recession just to reduce the amount of solid waste going into landfills. Alter (1995) says that policies to reduce solid waste could well have an impact on our quality of life: "Everybody favors solid waste reduction, but nobody has achieved it except for packaging. The rest is palaver. What is reasonable? Should we restrict people's reading habits? Forbid selling newspapers with more than four pages? This is quality of life stuff."

Packaging cannot be responsibly addressed as a solid waste problem without also considering its effect on the economy, resource management, product protection, consumer safety (packaging prevents tampering), and public health (packaging keeps germs out of food). Because source reduction would impact the nation's complex economic system in ways that are difficult to predict, Don Walter (1994-1995) does not think the federal government should orchestrate source reduction. Rather, he thinks consumers and industry should take the lead in minimizing solid waste: "Source reduction as an issue in the government absolutely scares me silly. We don't have enough smarts 
right now to know what the life cycle impacts of source reduction are. The Chamber of Commerce says that for every pound of plastic added to packaging in the $1980 \mathrm{~s}, 2.7$ pounds of food waste was avoided. Now if this is true, does reducing the amount of plastic mean food waste goes up threefold? If they do, we made a horrible mistake. I don't think ... the government ... [has] enough sense to start making these kinds of decisions."

\section{Consumers' Roles in Waste Minimization}

There are ways consumers can keep solid waste out of an MSW management system. Some work better than others. It is a matter of balancing convenience, cost, and impact on the environment. For example, the following suggestions for reducing solid waste have met with only limited success: use cloth grocery bags; pass up prepared meals, buy bulk foods, avoid quick-cleaning home-care products, and refuse to buy disposable diapers, razors, dishes, and so forth.

There is a problem with suggestions like these. Solid waste minimization is often in the eye of the beholder rather than objective reality. Whether a particular activity is good for the environment often boils down to personal values. Take the controversy over cloth diapers, for example. Two studies of cloth versus disposable diapers came up with opposite conclusions about which product is better for the environment. So what do we know for sure? Washing cloth diapers at home uses a great deal of energy and creates wastewater that must be treated to avoid pollution. Wastewater treatment, in turn, creates sludge requiring disposal. However, transporting diapers to and from a diaper service's facility causes air pollution and uses energy. Disposable diapers create lots of trash but have less impact on water quality. To further complicate the picture, commercial diaper services use less energy and produce less wastewater per diaper than home laundering. Many consumers do not consider these factors. They opt for disposables because they are convenient and affordable.

As we come up with ideas for reducing solid waste, we cannot afford to ignore consumer attitudes. In many households, all the adults work. How will busy people find the time and energy to put labor-intensive suggestions to work? In terms of solid waste, convenience has a price that most Americans are more than happy to pay. This fact is central to understanding why the nation creates so much solid waste.

The good news is that we can cut down on solid waste without too much inconvenience, particularly given the proper incentive. Some communities charge people who generate great quantities of solid waste more than people who do not produce very much. Another strategy is to provide free solid waste collection but limit each household to a single, relatively small container. Many people find the challenge of making do with a small trash can and variable collection charges incentives to reduce the amount of solid waste they create. How do they do it?

Actually, there is no single answer. Each household has to figure out what works best for its members. Fortunately, there are several ways to create less solid waste. For example, wasting even less food than we already do would lower solid waste. About $9 \%$ of the solid waste Americans set out every week is edible food that is spoiled or otherwise unwanted. Americans have already made a lot of progress in curbing food waste - thanks to packaging, which keeps food fresh longer-but there is still room for improvement. Another easy way to reduce solid waste is to use a mulching lawn mower instead of collecting and discarding grass clippings. The grass clippings essentially compost where they fall. The compost provides nutrients for the lawn. Americans could make a noticeable dent in paper waste if it were possible to curb unsolicited direct mailings, preferably 
without violating the First Amendment or shutting down the postal service. Individuals can contact the Mail Preference Service ${ }^{21}$ and ask that their names be removed from direct mailing lists.

The two major mid-winter holidays - Christmas and Chanukah — deserve special attention in any discussion of minimizing solid waste. During the last 2 weeks of December, Americans throw away more solid waste than at any other time of the year. It is possible to cut down on this particular solid waste blitz by: (1) using paper or cloth gift bags instead of wrapping paper and saving the bags and using them until they wear out; (2) reusing wrapping paper whenever possible; (3) recycling cardboard boxes - there is often a market for them; (4) taking yesterday's shopping bag along for today's purchases; (5) giving old clothes, toys, appliances, and cast-offs to charity rather than throwing them away; or (6) sending the Christmas tree to a mulching program after the holiday.

Some strategies for minimizing solid waste take almost no effort. Consumer choice is a good example. Retailers now offer concentrated laundry detergents, dishwashing detergents, floor-care products, and toothpastes that come in less packaging. Although the toothpaste inside a shrinkwrapped tube is just the same as in a tube sold in a box, many consumers select the boxed product out of habit. Because consumers continue to buy the boxes, manufacturers continue to make them and unnecessary solid waste is generated. Detergent manufacturers reduce packaging by removing water and fillers from their products. However, they have discovered that consumers do not buy the smaller packages because shoppers assume that they are getting less product for their money. Usually, the opposite is true. In 1995, for example, Consumer Reports magazine rated one such dishwashing detergent as its best buy. Unfortunately, by 1997 this product was no longer available in some states, due to lack of consumer response. Clearly, consumer education is crucial to effective source reduction.

Source reduction can save money at the office while reducing solid waste. For example, printing or copying materials onto both sides of the paper uses less paper and creates less waste. Toner cartridges for computer printers can be rebuilt and used again instead of thrown away.

\section{Keeping Toxic Waste out of Municipal Solid Waste}

Source reduction includes reducing the amount of toxic material in solid waste. Manufacturers of batteries, lawn care products, and even fingernail polish are required by law to treat product residues and empty chemical containers as hazardous waste. Individuals should recognize the hazard of just tossing such items into the trash. Finding alternatives to mercury in batteries, marketing less toxic pesticides for lawn and gardens, and finding substitutes for heavy metals and solvents in nail polish are all important industry goals for waste minimization.

About 1\% of household solid waste is hazardous (Rathje and Murphy 1992). Motor oil, gasoline additives, household cleaners, old or broken mercury thermometers, watch and calculator batteries, paints, sealants, glues, stains, varnishes, pesticides, weed killers, and fertilizers are some of the substances Americans regularly put out along with their household trash. Americans discard more than 2 million tons of hazardous waste each year.

\footnotetext{
$21 \quad$ Mail Preference Service

Direct Marketing Association

11 West 42nd Street

P.O. Box 3861

New York, New York 10163
} 
What happens to this waste? Some is taken to recycling facilities or special household hazardous waste-collection centers, usually as part of a special collection effort. But all too often, hazardous waste is thrown out with the rest of the week's residential solid waste. When that happens, toxic waste goes into the nation's waste-to-energy facilities and landfills. Many hazardous substances are destroyed by high temperatures inside waste combustion furnaces; some, including heavy metals such as mercury and cadmium, may end up in combustion ash inside a landfill. About two-thirds of the household hazardous waste discarded in trash goes straight into a landfill.

Is there anything the average American can do about this situation? Yes, people can reduce the amount of waste and toxicity of household waste - if they are willing to invest the time and effort to do so. Because few alternatives are as convenient and effective as the methods they replace, they may not spread like wildfire. The following suggestions come from EPA's Consumer Handbook for Reducing Solid Waste 1992:

- Use a plunger or plumber's snake instead of drain cleaner. [It isn't clear how many consumers would be willing to pay a plumber to fix clogged pipes in lieu of spending a few dollars on drain cleaner.]

- Use steel wool and baking soda [and elbow grease] on new oven spills rather than oven cleaner. [This suggestion fails to take account of the time demands on busy working women with families.]

- Use a toilet brush, baking soda or vinegar [and elbow grease] instead of toilet bowl cleaner [if you are happy with cleaning rather than disinfecting].

- Wipe houseplant leaves with mild soap and water, then rinse. [This technique replaces plant sprays and is actually quite effective for those who have time to implement it.]

- Use cedar chips, lavender flowers, rosemary, mint, or white peppercorns in lieu of mothballs. [The biodegradable "mothball" substitutes smell better, too.]

\section{Industry's Role in Waste Minimization}

Even without consumer feedback, manufacturers have a strong incentive to make products lighter, thinner, and more durable. Such endeavors, collectively known as lightweighting, can save companies money on raw materials and transportation costs. The savings translate into higher profits. Nowhere is this more apparent than in the computer industry. A modern hand-held microprocessor has the power of a 1970-vintage computer that once filled a small room. That is a roomful of solid waste when the microprocessor becomes obsolete. Some computer firms also sell factoryreconditioned items such as computers, printers, and toner cartridges along with new products, further reducing solid waste.

The plastics industry has made important strides in producing lightweight containers and other items. For example, a plastic 2-liter soda bottle weighed 68 grams in 1977 but only 51 grams in 1991, which is $25 \%$ less material. Plastic milk jugs weighed about 98 grams each in 1977, but only 60 grams in 1991, almost $40 \%$ less. Even aluminum cans are lighter than they were 20 years ago. Then, a pound of aluminum made 24 cans. Today, it makes 28 cans.

Even the much maligned disposable diaper weighs half as much today as it did when it was introduced in 1961. Modern "high-tech" diapers keep babies drier so fewer of them are needed each day. In addition, manufacturers have reduced packaging for disposable diapers by $80 \%$. 
Lightweighting has kept the percentage of plastics discarded in landfills nearly constant (at about $10 \%$ ) for the past 25 years.

There is a limit to how far the production of lightweight products can go in reducing solid waste, however. Less material makes containers less durable. Unlike heavy reusable glass beer and pop bottles, lighter glass containers are not strong enough to be used over and over. Nevertheless, the production of lightweight products has made a major contribution to source reduction. As Alter (1995) explains:

Packaging is the only solid waste reduction success story. Everything is lighter: foam cups, metals, glass, aluminum. New, flexible packages weigh only a few grams. You'd have to recycle $85 \%$ of metal coffee cans just to break even with the waste avoided by using brick [soft foil] packs. Polyethylene bottles could replace glass bottles and reduce waste, too. The Soviet vodka bottle is entirely recycled. It's so heavy you could drive nails with it. With all that tonnage, fuel consumption goes up to recycle them. Recycling is only an option. The way to reduce the intensity of energy and materials consumption is to use more plastic. In Europe, I heard about a new 5-gram polyethylene sack they want to use for milk. It takes 200 to 500 grams of glass for the same job. This is a fantastic package. We'd be better off to use it than to recycle the glass.

\section{State and Federal Initiatives to Reduce Solid Waste}

During the 1980s, some states considered laws designed to reduce solid waste, including product bans, packaging taxes, and container deposit laws. The deposit legislation has been more successful in controlling litter than in encouraging recycling or in reducing solid waste generation. Lanny Hickman (1995-1997) is not surprised:

We can talk about all the options that are open to us, but [solid waste professionals] can't do a thing with MSW until it's put on the curb. EPA doesn't agree with us on this. They think local governments and solid waste managers can be very effective at waste minimization. I think some of the work they're doing with industry now, on a voluntary basis, on waste minimization and pollution prevention, has great merit. It raises the level of consciousness. But it'll probably only have a couple of percent effect on the amount of solid waste that's generated or not generated. I think that no matter how hard we work at solid waste reduction and recycling and changing the way products are made over the next 20 years, we'll just keep even. There's going to have to be a dramatic change in the way we do things in this country, and that's not going to come about easily.

The 1970 Resource Recovery Act called for a study of manufacturing and packaging to see if waste generation could be reduced. In response, EPA created a waste reduction branch to study beverage container deposits, milk packaging, and tires. EPA prepared four reports for Congress in the mid-1970s, and then turned its attention to hazardous waste. The agency revived its waste minimization efforts in 1988.

EPA currently has four strategies that aim to encourage solid waste minimization: waste audits, economic incentives, procurement guidelines, and government assistance. A waste audit reviews a company's total solid waste production and identifies ways to reduce the amount produced. 
For example, common strategies for solid waste reduction include composting lawn clippings and setting photocopiers to copy on two sides. From 1992 to 1994, EPA worked with Colorado State University in Fort Collins, Colorado, to evaluate the potential impact of the agency's "Waste Wise" program on specific businesses, including a major homebuilder, a hospital, a grocery chain, a ski resort, and a manufacturer of photographic supplies. The study looked at office paper, packaging, landscaping waste, and other typical components of industry solid waste. It revealed numerous ways for the firms to reduce solid waste generation and save up to $\$ 348,000$ per year by investing in source reduction activities. The study concluded that both source reduction and reusing materials were cost effective for the industries studied.

EPA's economic incentives for reducing the volume of solid waste and encouraging recycling include variable-rate pricing. This pricing strategy raises the cost of trash collection and disposal for businesses and households as the volume of waste increases. The agency has also developed procurement guidelines for federal agencies and is sharing them with interested companies in an effort to encourage markets for recycled materials. Procurement guidelines typically establish a set percentage of supplies, such as paper towels, office paper, or even some construction materials, that must contain recycled materials. EPA also helps fund state efforts to attract new recycling businesses and jobs.

\section{Profile: Steve Levy}

Steve Levy joined the U.S. Public Health Service's MSW program in 1966 soon after he finished college. Levy (1995) explains why he came into the field unprepared: "We didn't study solid waste management in college. There were no courses. Public works directors weren't trained with any kind of technology. There was no guidance on what they were supposed to do. There was just the local dump. They collected the garbage and they disposed of it the same way they'd sweep the streets and change light bulbs in lampposts."

Levy went on to earn a master's degree in environmental engineering with a specialty in MSW combustion from Drexel University. During a nearly 30-year tenure with EPA's Office of Solid Waste, he has been involved with all aspects of MSW management at the federal level. He specialized in the development of new technologies for resource recovery and recycling. Levy is currently an environmental engineer in the Municipal and Industrial Solid Waste Division in EPA's Office of Solid Waste.

Levy developed and edited an electronic reference manual for MSW in 1995. Entitled the MSW Factbook, the manual is contained on a diskette and runs under Microsoft Windows ${ }^{\circledR}$ software on a personal computer. The manual presents information from several dozen EPA solid waste publications in a single, easy-to-use format. Version 3.0 of the MSW Factbook is available from EPA's Office of Solid Waste Publications Distribution Center in Washington, D.C., or on the Internet from EPA's file server at: www.epa.gov. 


\subsection{Materials Recovery}

Recycling is a good idea. It always was. ${ }^{22}$

In general, the materials we use are taken from the earth, manufactured into products, used, and then dumped back into the ground in a landfill. Even if solid waste is burned for energy recovery, the ash goes into a special landfill called a monofill. Once materials are discarded into a landfill, their remaining economic value is frequently lost. Salvaging materials for recycling addresses the issue of wasting material resources.

Recycling dates back to ancient times. As Don Walter (1994-1995) notes, "It's hard to tell whether recycling started with a fig leaf in the Garden of Eden or with the jawbone of an ass." Of necessity, pre-industrial societies reused products and recycled materials. Raw materials were often difficult to obtain. Skilled artisans spent too many hours making tools, weapons, jewelry, and household items to just throw them away.

During the eighteenth and nineteenth centuries in the United States, ragpickers were the cornerstone of an efficient and lucrative recycling system. They collected used paper and cloth rags for sale to eastern paper mills. The mills combined fibers from these materials with virgin wood pulp to make paper. Ragpickers earned about $\$ 350$ (in 1989 dollars) per ton of rags - more than two and a half times the average price for old newspaper in 1995. Ragpickers also collected other items for resale. For most of this century, their modern descendants have collected, processed, and sold millions of tons of old newspaper, cardboard, and scrap metal from old cars and used appliances. The scrap industry flourished long before the current recycling era. With this one notable exception, however, America's commitment to recycling has been an on-again, off-again affair.

One early recycling activity occurred at Chicago's rendering plants, which began operation during the 1850s. City street cleaners gathered dead animals and brought them to the plants, which were known as "disposers." From the carcasses, the plants rendered grease that was then used in the windy city's cable cars. Other products included soap, explosives, and tankage (the dried material left over after fat is removed from animal carcasses and used as fertilizer). Although other cities experimented with rendering as a disposal method, it was never widely used. Rendering plants emitted foul odors, and people living near the plants were often nauseated by the stench.

In 1896, Colonel George E. Waring, Jr., New York City's renowned street cleaning commissioner, asked residents to separate their solid waste. His goal was to recover valuable items from solid waste and then sell them to help finance his solid waste management system. Waring was well aware that ragpickers and scowtrimmers were reaping tidy profits by recovering valuable items such as old shoes, carpets, paper, and rags. Waring wanted the city to profit from these lucrative ventures as well. Soon, New York householders routinely set out food waste, rubbish, and ashes in separate containers for collection. In a sense, Waring initiated the nation's first "curbside" recycling program.

Waring opened a recycling plant where workers picked out valuables from waste on a conveyor belt. Glass bottles, steel cans, cardboard, rags, and felt hats were recovered and sold. Waring burned what was left to make steam to drive the conveyor belt. Recycling's most eminent

\footnotetext{
${ }^{22}$ Alexander, Judd H. (1993). In Defense of Garbage. Westport, Connecticut, and London: Praeger, p. 99.
} 
pioneer also salvaged ammonia, grease, glue, and fertilizer from the city's solid waste and sold them for profit.

Following New York City's lead, other cities adopted their own source separation requirements. In many cities, food waste was fed to hogs, which were kept on nearby farms rather than being allowed to freely roam city streets. Newspapers were also collected for recycling in many cities, particularly on the East Coast. Grayish-brown boxboard items, such as cereal boxes and the rollers inside toilet paper and paper towels, have been made from recycled paper at least since 1905. Materials recovery was actively promoted during World War I. Harvey Alter (1995) describes this era:

Curbside recycling goes back to World War I. The Salvation Army truck was almost like a junk wagon. Scrap peddlers started by carrying the stuff on their backs. When they got enough money, they bought a pushcart. More money, they got a horse to pull the cart. I remember, as a kid, the guy coming around with the cart and cowbell in the back to announce he was coming. This was a garbage man back then, a scavenger. We kids might get a penny for finding a piece of metal at a construction site. Even today, if I have plumbing waste, I can't bear to throw it away. I take it to the local scrap yard.

Despite intensive recycling during the war, solid waste management was already moving away from recycling toward the simpler and less expensive options of land dumping and incineration. Following World War I, salvage companies continued to do a brisk but increasingly competitive business.

The Depression forced many cities to look for inexpensive, one-stop solutions for disposing of unprocessed solid waste. As landfilling increased and markets for recovered materials stabilized at relatively low levels, municipalities lost interest in source separation and recycling. Scavenging declined because local governments began selling salvage rights at the local dump to the highest bidder and kept everyone else away.

During the Depression, companies were forced to seek out every possible source of revenue to keep costs low. Salvage crews often rode on collection trucks, recovering rags, bottles, aluminum, newspaper, cardboard, and other materials by sorting through the solid waste as it was collected. Bottles were a major source of income. These were washed, packaged, and returned to distributors for reuse. Until the 1950s, customers breaking milk bottles instead of returning them had to pay for them. Deposits encouraged people to return and recycle soft-drink bottles.

Even as the salvage industry was thriving, the introduction of motorized collection vehicles provided efficient collection systems that were better suited for landfilling and incineration than for recycling. At the same time, the solid waste stream began to include increasing amounts of packaging (paper and tinfoil) and single-use, throwaway items such as paper cups. As these items became more widely used, Americans began to view solid waste more as discards for disposal than as salvageable products or resources.

The trend away from recycling was temporarily halted by World War II. The United States began a national recycling effort, linking materials recovery with patriotic duty. Americans collected newspaper, string, tin cans, grease (a source of glycerine needed to make explosives), aluminum, and tinfoil for recycling. Walter (1994-1995) participated in these efforts as a child: "During World War II, I used to sit and peel the metal [foil] from the paper on my father's cigarette packs and recycle [it]." By the end of the war, as much as $35 \%$ of wood-fiber products such as paper and cardboard 
were recovered (Blumburg and Gottlieb 1989). Public response to requests for used materials occasionally exceeded the nation's capacity to use them, however. Newspapers and other materials were dumped (on land or into the ocean) whenever supplies outstripped demand. The public was typically not informed of this practice.

Interest in recycling waned following World War II. The salvage industry faced ongoing problems with declining markets for recovered materials. The firms that continued in business began to limit recycling to newspapers, corrugated cardboard, appliances, and other materials for which there were still markets. Some materials, such as newspapers and steel cans, were collected separately from residential solid waste, a costly but necessary step. Newspapers contaminated with food waste had no value on the resale market. Beginning in the late 1940s, scout troops and civic organizations raised money by collecting recyclable materials and selling them to salvage companies.

In the 1950s, kitchen garbage disposals became popular. The new invention reduced the amount of food waste in the solid waste stream. ${ }^{23}$ At the same time, the use of paper and plastic packaging soared, further reducing the amount of food waste, but increasing the amount of packaging waste. To deal with increasing volumes of solid waste, thousands of local governments purchased compaction trucks. The new trucks essentially eliminated manual sorting of salvageable materials. Shortly thereafter, the majority of collection companies closed down their salvage operations. For most of the 1950s, automobile manufacturers were about the only market for recycled cardboard. Because recycled cardboard was used to make car headliners, ${ }^{24}$ the price of recycled cardboard rose and fell according to the number of new cars rolling off the assembly line.

During the 1960s, a few military installations and government agencies recycled paper. Scout troops and other organizations continued to raise money with paper drives. However, with the exception of the automobile industry and a small salvage industry that reclaimed metal from wrecked automobiles and old appliances and sold old newspapers abroad, recycling played almost no role in solid waste management.

\section{The Federal Role in Recycling}

A stronger emphasis on recycling became apparent in government research laboratories during the latter half of the 1960s. Under the auspices of the 1965 Solid Waste Disposal Act, the U.S. Bureau of Mines began investigating technology in 1966 for reclaiming metals and glass from MSW incinerator ash. The same year, the U.S. Public Health Service launched an ambitious multifaceted solid waste research program that included composting and materials separation and recovery.

The 1970 Resource Recovery Act sowed the seeds for the modern era of recycling by shifting the emphasis of the federal MSW program from disposal to recycling. Federal research programs and public concerns both reflected the change. During the 1970s, government agencies evaluated recycling with the help of NCRR, whose mission was to promote resource recovery. NCRR, which operated from 1972 to 1980, was a private research and public information organization based in Washington, D.C. NCRR, which was funded primarily by private industry, had additional support

\footnotetext{
${ }^{23}$ Food waste did not disappear with the advent of the garbage disposal. It went into septic tanks or a municipal sewage treatment system instead.

24 Car headliners are the material between the metal roof of the car and the fabric on the inside that make the roof soft to the touch. The paper liners were supposed to deaden sound and provide some insulation.
} 
from government contracts and grants. The government supported NCRR research on materials separation, worker health and safety, size reduction, air classification, aluminum can crushers, and feasibility studies of materials and energy recovery. NCRR was instrumental in developing specifications and methods for recovering aluminum cans, glass, and nonferrous metals from MSW. It also helped develop specifications for recovering metals and paper from solid waste. The operation of many modern materials recovery facilities is based upon the specifications developed by NCRR. Alter (1995), who worked for the NCRR during the 1970s, explains the rationale behind developing specifications for recovered materials:

The specifications for recovering glass were very tight. It had to be broken into fine particles. We recovered it by froth flotation. It had to be free of aluminum, because aluminum reduces glass and causes black silica spots. You couldn't have any organic material or you'd get bubbles. No stones or ceramics, either, because they cause defects in new glass products, making them prone to breakage.

Other materials had tough specs, too. Aluminum: You don't want chairs mixed in with cans because they're [made from] different series alloys. You can make new sheets for cans from cans, but you don't want [to include] any siding or tubes because they have too much silica. Silica [contaminates] the new sheet, which then has no material value. It's good only for caskets.

NCRR pioneered marketing of recovered materials. As part of this effort, it co-sponsored the first National Materials Conservation Symposium on Resource Recovery and Utilization with the National Bureau of Standards at the bureau's Gaithersburg, Maryland, facility in 1973. Alter (1995) talks about the goals of NCRR's efforts to develop markets:

We answered questions like these: What is the technology? What are the markets? How do you secure them? There's no point in building a plant to recover materials unless you know what materials you're going to recover and to what specifications you're going to design the equipment.

We set out to build a demonstration plant - 550 tons/day in New Orleans - and subsidize it. The idea was to recover newspaper, steel in two grades, cans, aluminum, nonferrous metals, and glass. These materials were brought into the facility in a packer truck and mechanically sorted. We were unscrambling the egg.

\section{The U.S. Bureau of Mines}

Using research done in the 1960s, the U.S. Bureau of Mines operated a pilot plant during the 1970s that removed ferrous metals and other recyclable materials from incinerator residues. The bureau also worked with the American Society of Mechanical Engineers to evaluate a high-tech process, known as vitrification, for recycling ash into insulation materials. The process used an electric arc furnace to harden and stabilize ash and other waste. It was tested successfully with waste combustion ash, fly ash from an RDF plant, and sewage sludge. 


\section{The U.S. Environmental Protection Agency}

EPA's Office of Solid Waste undertook several resource recovery programs during the 1970s. As broadly defined by the agency, resource recovery included a variety of technologies for recovering anything of value from the waste stream. Thus, the resources recovered included both energy and materials.

EPA conducted studies on recycling newspaper, paper products, aluminum, glass, tires, and plastics. By the end of the decade, EPA concluded that it would be possible to increase recycling rates of $5 \%$ to $7 \%$ of total waste generation to at least $25 \%$. To accomplish this, EPA officials proposed economic incentives, including federal procurement guidelines and a national deposit tax on beverage containers.

EPA's suggestions were reviewed by the Resource Conservation Committee, established by RCRA to, among other things, define the federal role in recycling, reuse, and source reduction. Committee members included the Secretaries of Interior, Treasury, Labor, Commerce, and Energy; the heads of EPA; the Council on Environmental Quality; the Office of Management and Budget; and the Council of Economic Advisors.

Two programs received the majority of the committee's time: beverage container deposits and a national solid waste disposal charge. Other programs considered by the committee included a national litter tax, local user fees, deposits and bounties on durable and hazardous goods, product regulations, the elimination of rail freight schedules that favored virgin materials, subsidies for resource recovery programs, extraction taxes on virgin materials, and the elimination of federal subsidies for virgin materials. The committee rejected a national solid waste disposal tax and product regulations and failed to agree on any other proposals.

The committee's most controversial and divisive issue was the beverage container tax proposal. The issue, which underwent acrimonious debate in Congress and in several states, had equally enthusiastic supporters and detractors. Because several states actually enacted beverage container deposit laws, we can see, in retrospect, that beverage container deposit laws provided few, if any, environmental benefits. The laws failed to increase recycling rates. Even when people collected containers, retailers were not necessarily willing to pay for shipping them back to where they came from and manufacturers were not necessarily willing to take them back.

The laws had several unintended consequences. They unfairly impacted poorer citizens by raising the price of beverages. Some residents of states with deposit laws began driving to nearby states to purchase less expensive beverages, using more gasoline and increasing air pollution. And because some deposit laws banned containers that could not be recycled, they blocked the introduction of new and improved container technology. Thin, layered paper and plastic juice containers that produced far less waste than glass containers were prohibited for several years in at least one state. Despite the many drawbacks of container deposit laws, few have been repealed. Don Walter (1994-1995) is delighted that only a few of these laws exist:

In my opinion, it's fortunate we don't have a lot of bottle bills around. Why in the world is somebody going to want to return a bottle or a can for 5 cents? [The bottles] are basically going to end up in a trash heap [because the deposit is too small to make it worthwhile returning them]. In the late 1930s and early 1940s, kids, including me, collected bottles from the street and shopped around to find someone to give us the 2 -cent deposit. Why do we believe 50 years later that 5 cents - a lot less money in a more affluent society — will keep litter off our streets? 


\section{The Modern Recycling Era}

During the 1970s, Americans began to see recycling as a means of reducing the amount of solid waste requiring disposal and recouping some of the economic value of their discards. Drop-off recycling centers and curbside recycling programs began to appear around the country. Initially, many were a result of grassroots efforts to reintroduce recycling into solid waste management. Newspapers, bottles, and aluminum cans were the focus of most volunteer-driven efforts. As time went on, public pressure forced officials in some cities to begin to pay attention to recycling, but most solid waste management continued to focus on landfilling and other disposal technologies well into the 1980s.

The volunteer programs contrasted sharply with the scrap industry. As a result of volunteer recycling, the scrap industry experienced a glut of recovered materials that sent market prices tumbling. The industry had little affection for the idealism underlying the new recycling movement. As committed as they were, the volunteers had little understanding of the salvage business and often confused waste diversion with recycling. ${ }^{25}$

Despite recycling's promise, the impacts of federal recycling research and volunteer efforts were minimal at first. During the 1970 s, recycling rates held steady at about $5 \%$ to $7 \%$ of the solid waste stream. Because wrecked automobiles and appliances were not normally counted as part of solid waste, newspaper, cardboard, and aluminum cans made up most of the materials recycled during the 1970s. Of these, aluminum recycling increased most rapidly, due to the high price commanded by scrap aluminum and the establishment of an infrastructure to support recycling. Scrap aluminum's high price reflected the enormous amount of energy saved by recycling aluminum cans as compared to manufacturing them from virgin materials. In 1967, the nation had just one aluminum can collection center. Ten years later, there were 1,300. By 1975, one out of every four aluminum cans was recycled. The market for recovered aluminum cans remained strong through the mid-1990s, when this report was completed.

\section{Recycling in the 1980s}

The nation's enthusiasm for recycling waned temporarily during the early 1980s. Even though the national recycling rate had crept up to nearly $10 \%$ by 1980 , falling oil prices, fears about hazardous waste, and the election of a more conservative Reagan administration diverted the public's attention from materials recycling. Resource recovery, which had originally encompassed recycling, was increasingly defined as energy recovery from waste. The move to build new waste-to-energy facilities continued even as interest in materials recycling dwindled. Because the emphasis on waste combustion occurred at the same time as people lost interest in recycling, the technology was mistakenly interpreted as a threat to intensive materials recycling. Environmental groups, in particular, did not understand that solid waste combustion's primary competitor was (and continues to be) landfilling.

Recycling grew slowly through most of the 1980s because the cost of recycling was higher than the cost of solid waste combustion or landfilling. In addition, there were insufficient markets for recovered materials and other infrastructures to support an expanded recycling industry. For these reasons, local officials and the solid waste management industry initially resisted a change of

25 Waste diversion occurs when materials are removed from municipal solid waste, in a curbside recycling program for example, prior to landfilling. Diverted waste may be recycled, composted, sent to a waste combustion facility, or landfilled. Recycling occurs only if diverted waste is remanufactured into useful products. 
emphasis from disposal to recycling. Undaunted by these obstacles, private citizens and environmental groups worked diligently to institute curbside recycling programs and recycling centers throughout the 1980 s.

As part of their effort to promote recycling, environmental groups forced EPA to develop procurement guidelines for recycled materials. The agency had been directed to produce such guidelines both by RCRA and HSWA. In 1987, the Environmental Defense fund, the Environmental Task Force, the Coalition for Recyclable Waste, and the National Recycling Congress successfully sued EPA to require the agency to expeditiously issue procurement guidelines, which were soon forthcoming. Despite their political appeal, Walter (1994-1995) was skeptical about the long-term benefits of such guidelines. He says that for at least the past 25 years, goods made from recycled materials have cost more than goods made from virgin materials:

I think every president so far has issued a statement early in his term of office saying that [the federal government is] going to buy recycled materials. Well, the first one of those I ran into was in 1971 when I was facility engineer at Fort Detrick. Down comes this presidential order that we should buy more recycled materials and run a recycling program, which we did. So the idea of having the federal government buy more recyclables and pay $10 \%$ more for them is by no means new-it's an antique policy. It always fascinates me why people think that since it didn't work in one of its incarnations that they have to issue another one and do it all over again, when it has already not worked seven or eight times.

Another boon to recycling came amid unfounded fears that the nation was running out of landfill space. Within months of the public misperception that a "garbage crisis" occurred in 1987, recycling was touted as a panacea for solid waste management. Community activists fervently pressured public officials to launch recycling programs. Almost overnight, state and local officials began recommending municipal recycling goals of $25 \%$ or even $50 \%$. The most optimistic recycling advocates began promising recycling rates of $70 \%$ or even $80 \%$.

Because it was an election year, there was widespread pressure on the federal government in 1988 to respond to the public's new fascination with recycling. Steve Levy (1995) recalls how EPA came up with a goal of recycling $25 \%$ of solid waste by 1992 :

After EPA got back into solid waste in the late 1980s, the [head of EPA's Office of Solid Waste] made a speech saying we should establish a national target of recycling one-quarter of our waste in four years. The speech was just before the [November 1988] election. That statement didn't come from any economic, environmental or technical analysis. It was purely a sound bite. It made good press. All of a sudden you couldn't pick up a magazine without reading about $25 \%$ recovery rates. Plus, you had all these governors and others running for election, and they'd say, "Well, if the federal government can do $25 \%$, then here in our state where we're so much more environmentally conscious, we can do $50 \%$ !"

\section{Recycling Realities}

Not surprisingly, people began to believe recycling was the perfect solution to solid waste management. Many people thought that it was, without exception, good for the environment. Its supporters believed there were few, if any, practical limits to achieving extraordinarily high recycling 
rates. Most importantly, curbside recycling was convenient, and it did not demand that Americans change their normal consumption habits. If this all sounded too good to be true, it was.

Curbside recycling was convenient but not particularly sanitary. The open containers used in most cities were an attraction to dogs, cats, and other animals. Newspapers and paper readily blew out of the containers on windy days, scattering trash throughout neighborhoods. Alter (1995) believes that the collection of recyclable materials should have been held to the same standards as other solid waste collection from the beginning:

[Open containers] were a terrible thing. I wanted new regulations requiring closed containers for recyclables. Then you could subsidize recycling by [having the city or the trash collection company] clean the containers. It's always mystified me that it's OK to place recyclables on the curb, but it's not OK to set out trash in plastic bags - which, by the way, is the cheapest way to collect trash. Crews can do more homes in less time. [Using plastic bags] keeps labor costs down.

Despite the grandiose claims, public works managers found they were lucky to achieve recycling rates of $10 \%$ to $15 \%$. Meanwhile, they encountered growing opposition to siting needed landfills and waste-to-energy facilities. EPA's Steve Levy (1995) explains how public works managers found themselves between a rock and a hard place with respect to recycling: "All of a sudden, public works directors, city managers, or anybody trying to make a solid-waste decision were under the gun to do recycling. People told them, 'Why should we give you a nickel for that stuff until you maximize recycling? Get your recycling up to $25 \%$, then we'll talk to you about building an incinerator."' Public officials began making critical decisions based upon untested claims rather than recycling realities. Waste-to-energy projects were put on hold. Counties declined to create new landfills based on (faulty) projections that the majority of solid waste could be recycled. New landfills and waste-to-energy plants simply could not move forward until a community put a recycling program in place. Alter (1995) is critical of the process that led to such poor decisions:

People recycle because they think they are making a contribution and it's worth their while. But when it gets harder and more expensive to recycle, participation will [drop]. So what will happen if we don't recycle? Will the planet go to hell if we put glass or metal in a landfill? No. The [driving force] should not be recycling. The [driving force] should be (1) maintenance of public health and (2) a reduction in the use of energy and materials. If it pays, recycle it.

Communities discovered recycling was not as simple as it sounded. Local governments had to figure out what to collect, how to collect it, where and how to sort it, who would sort it, where to sell it, how to transport it, how to pay for the program - and so forth. Levy (1995) explains why this transition was so difficult for public works managers: "Recycling only sounds simple. When you try to set it up, you need trucks and a place to unload them. You need markets. You have to figure out how to get the trash flowing through your facilities every day. It's a big undertaking. And it's something communities weren't used to. They weren't used to selling paper every day. Cities are buyers, not sellers. They got strapped, not just in terms of money but in terms of resources and manpower." 
What actually happened with recycling during the 1980s was a far cry from the claims that recycling could manage $40 \%, 50 \%$, or even $80 \%$ of the total waste generated. Recycling increased steadily around the country during the 1980 s, albeit at rates well below even the most conservative projections. Between 1985 and 1992, the amount of materials recovered for recycling increased by $150 \%$, from about 16 million tons of solid waste (or about $10 \%$ of the total) in 1985 to more than 40 million tons (or about $21 \%$ of the total) in 1992.

Many factors contributed to the increase in materials recovery. By the late 1980s, the majority of the solid waste management firms in the United States offered recycling as one of their services. Curbside collection programs grew from 1,000 in 1988 to more than 7,265 in 1994. The number of materials recovery facilities (MRFs) increased from 13 in 1985 to 198 in 1992. By 1994, 41 states had passed comprehensive recycling and waste reduction laws, and 44 states had established recycling or waste reduction goals, ranging from $20 \%$ to $70 \%$. As the realities of waste diversion and recycling sank in, however, many states had to postpone and revise goals that were unrealistic and unattainable.

As solid waste diversion efforts grew, markets for recovered materials became saturated. Prices, which had held steadily since the 1950s, began to fall. By 1991, a glut of recovered materials materialized. Prices plummeted, and recovered materials were quietly shipped to the nearest landfill. It took 3 years for market development to catch up with the supply of recovered materials. Markets for materials rebounded in 1994 as new remanufacturing facilities opened in many locations. Markets have continued to be volatile since then, however.

As a result of such setbacks, solid waste management professionals now have a clearer understanding about what recycling can accomplish. For example, recycling will not solve the problem of increasing solid waste generation. Even though the recycling rate has steadily risen since 1988, EPA's estimate of the amount of solid waste going into landfills has remained constant at about 130 million tons per year. Recycling may have kept up with increased generation, but it has not made a dent in the total amount of solid waste buried in landfills.

Although it is no longer considered a panacea, recycling has the support of the American public, government agencies, environmental groups, the solid waste management industry, and public works managers. Nevertheless, recycling and composting are still a distant second to landfilling for managing solid waste. Between 1985 and 1994, the recycling rate for solid waste increased from about $10 \%$ to $23 \%$, keeping up with overall increases in solid waste generation.

EPA projects that $30 \%$ of MSW could be recycled or composted by the year 2000 . For this to happen, however, several things must occur. According to a 1994 study by Keep America Beautiful, Inc. (KAB), commercial recycling must increase significantly, the number of curbside recycling programs must double, and the diversion and composting of yard waste must count toward overall recycling goals. Yard waste composting already accounts for much of the recent increase in the nation's recycling rate. Alter (1995) explains some of the reasons behind the study's conclusions: "You can't make any of these ambitious recycling goals with household waste and curbside collections. About 55\% of MSW is commercial. Why put your emphasis on household waste? There are great goodies in commercial waste. If you want to manage MSW to get high recycling, you have to focus on commercial waste. You also need to recycle at least half the yard waste just to make $25 \%$."

The KAB study determined that it would require more than source reduction, recycling, and composting to achieve national recycling rates greater than $35 \%$. In a similar study, the city of Chicago discovered that the best recycling rate it could hope to achieve would be about $38 \%$. Higher 
recycling rates are likely to increase solid waste management costs in most communities. We do not know if local governments will be willing or able to handle the higher costs.

It appears there are practical limits to achieving recycling rates of $50 \%$ or higher. The poor quality of many discards, scrap prices, market availability, and high costs all limit recovery rates. Even when market prices for recovered materials are high, recycling often costs more than sending solid waste to a landfill. Although curbside recycling is the most convenient method for recovering materials from private residences, it is also the most expensive because of collection costs.

Recycling does not necessarily save on landfill costs either. If a community ships its solid waste to another country or state, then recycling a ton of material may save whatever the tipping fee would have been to landfill that material. However, if a community owns and operates its own landfill, there are fixed costs that do not change even if less solid waste is landfilled. Walter (1994-1995) describes experience of Montgomery County, Maryland, to illustrate this point:

Montgomery County, Maryland, entered into a big recycling program and diverted a lot of solid waste out of its normal collection system. As a result, [there were] fewer tons going to their landfill. But they did not get rid of any equipment, any land, any operations, any people from the landfill, so landfilling costs stayed the same. Unless you can pull solid waste out of the system and have the landfill price go down, there is absolutely no way recycling can save money. And I'm not even talking about the cost of putting an extra truck and driver on the street to pick up recyclables or about the pollution caused by the extra truck on the street.

To achieve the modest recycling rates envisioned by KAP, more than 6 of every 10 Americans will need a curbside recycling program. And as more recyclable materials become available, new remanufacturing facilities and larger markets for recycled products will be required. As these adjustments take place, scrap market prices are expected to vary considerably.

\section{Reuse}

Today, reuse is distinguished from recycling. Reuse means exactly what it says. Instead of being discarded, an item continues to serve a purpose, often for someone other than its original owner. Reuse occurs when someone cleans a plastic yogurt container and uses it to store leftovers. More often, reuse takes place as a result of garage sales, second-hand stores, charitable donations, and scavenging.

Recycling happens when discards are collected and made into new products. If glass bottles collected in curbside collection and drop-off programs are used to make new glass containers or paving material, they have been recycled. If they are deposited in a landfill, they have not been recycled. Walter (1994-1995) underscores this point: "I was reading a recent report by EPA, DOE, and SWANA that looked at six materials recovery facilities. One of them collected 30,000 tons per year and actually sold 13,000 tons per year. That means 17,000 tons, almost $60 \%$ of what was collected, actually was going to a landfill." Curbside collection is an expensive method for collecting waste destined for a landfill. Collection is an important reason why recycling is costly, too.

\section{Recycling Costs}

Most recent studies have concluded that, in many cases, recycling is more expensive than solid waste combustion or landfilling. Increased collection costs account for much of the difference, 
but MRFs are also more expensive to operate than landfills. Even so, many communities support local recycling programs in spite of their higher cost. "Just because the economics of recycling is marginal does not mean the public should not participate in recycling programs," says Alter (1995). It is important, however, that people be given a realistic picture of what they are doing. Alter (1995) says government should "inform the public, tell them the truth. Recycling will cost you this much more than other waste management methods. Don't hide it. If people want to do a dumb thing, they're entitled to do it. Cities should tell people how much it's costing them, then let the political system work. Too often, ideology gets in the way."

A recent study of the economics of recycling in Europe (Hummel et al. 1996) suggests that although recycling is not always cost effective, it can be affordable under certain conditions. The study presented the following conclusions:

- Drop-off centers are cheaper than curbside recycling programs, but they result in lower solid waste diversion rates.

- When disposal costs are low (i.e., for landfilling) and markets for recovered materials are weak, even small amounts of recycling can raise MSW management costs, sometimes markedly.

- When disposal costs are high (i.e., for waste combustion) and recovered material markets are robust, a substantial fraction of solid waste can be affordably recycled.

The study offered several suggestions for reducing the cost of recycling, including increasing sales revenues, making operations more flexible, matching material specifications to market demand, reducing the number of collection vehicles, and designing routes for increased collection efficiency.

\section{The Environmental Impact of Recycling}

Because the recycling industry is growing so rapidly, researchers have begun to look at recycling's impact on the environment. They have discovered that recycling may not always be the best choice. For instance, a 1994 Argonne National Laboratory study concluded that the environmental impact of recycling depends upon how far, and by what means, solid waste is transported. If paper is transported more than a few hundred miles by truck ${ }^{26}$ for recycling, air pollution increases. Recycling means that fewer trees, which are a renewable resource, must be harvested to make paper, but environmental quality suffers. Because most paper is made from fastgrowing plantation trees rather than from forest trees, recycling paper may actually cause more harm to the environment than making new paper. Plantation trees not only provide pulp for paper, they also remove carbon dioxide from the air and provide more than half the energy needed to make the paper. In contrast, paper remanufacturing typically relies exclusively on fossil fuels. Paper remanufacturing also creates significant amounts of waste that must be managed. Alter (1995) is critical of the trend toward recycling magazines, for example; he notes that supporters appear to be unaware of the environmental impact of recycling them:

Post-consumer magazines have found a new market by going into newspaper recycling. They're a very cheap source of new fiber, and it's OK to mix both kinds

\footnotetext{
${ }^{26}$ Rail transport uses significantly less fossil fuel than truck transport.
} 
of paper. So, we can now take magazines and recycle the paper and get a big sludge. There are lots of nonfibrous materials in magazines.

What's better for the environment? Taking these heavy magazines and shipping them someplace, taking out a low yield of fiber and a lot of sludge, and saying we're protecting the environment? Or burying them in a hole in the ground? Remember, recycling is a strategy for solid waste management, not an end in itself.

The Argonne study found that recycling office paper saves less energy than recycling newspapers because the chemical processes that produce better quality papers also make them difficult and costly to recycle. In addition, there are no studies of the pollution caused by paper remanufacturing. It may make more sense environmentally to burn quality waste paper for energy than it does to recycle it, according to Don Walter (1994-1995).

If glass is shipped by truck more than 100 miles for remanufacturing, it takes more fossil fuels to recycle it than to make new glass from raw materials, according to the Argonne study. This conclusion may surprise people who do not know that it is not very complicated to make glass. It is just a matter of mixing sand, minerals, and a source of carbon dioxide (such as sea shells), then adding a large amount of energy, and putting the mixture through a manufacturing process. From an energy perspective, the difference between making glass from raw materials and remanufacturing it is just 100 miles. From an environmental perspective, however, there is a difference. The pollution from a diesel truck hauling used glass is a lot worse than the emissions from burning natural gas to make new glass. Diesel fuel is a dirty, largely imported fuel; natural gas is a domestic, clean fuel.

Grinding glass up and using it to make pavement, or "glassphalt," may be preferable to remanufacturing it into new containers. Even so, there is no good reason to assume that recycling glass is better for the environment than landfilling it, according to Walter (1994-1995):

Frankly, if you put glass in a landfill, it sits there. It has no environmental effect whatsoever. [Glass] is sand, the most abundant thing on earth, and it doesn't degrade. So what difference does it make if you put it into a landfill or you send it back to make new glass or you grind it up and use it as sand?

Recycling plastic containers saves energy, according to Argonne researchers. It also saves oil, the raw material from which plastic is made. Plastic can also serve as an energy-rich fuel in waste-to-energy combustion. Which is better for the environment: recycling or burning? Preliminary assessments of the environmental consequences of burning versus recycling plastic suggest a toss-up.

Aluminum is one material for which recycling usually makes sense, according to Argonne and almost everyone else. This lightweight material is easy to separate from solid waste and relatively inexpensive to transport. Most important, recycling aluminum saves about $95 \%$ of the energy needed to manufacture aluminum products from virgin materials-regardless of how far it is transported for recycling. Because most of the energy saved by recycling aluminum is electricity, the energy savings translates into a lower impact on the environment. Walter (1994-1995) offers his opinion on recycling aluminum: "Aluminum is the star of recycling. It's a shame to throw away an aluminum can [and have it end up in a landfill]. I have on occasion gone around DOE picking up aluminum cans out of trash cans. I picked out the aluminum cans from my own boss's trash and took them out for recycling. It's worth it. It's the smart thing to recycle and we ought to do it." 
There is no solid waste management method, including recycling, that does not generate some pollution. However, researchers have spent relatively little time looking at the environmental impacts of recycling. Therefore, it is up to each local government to look at waste management choices and select those that benefit the environment. In the Plains states, for example, it might be better to choose waste-to-energy conversion over recycling paper if the nearest paper mill is hundreds of miles away. It might also be better to crush glass to use as landfill cover or in pavement than to ship it to another state to make new containers.

\section{Recycling Markets}

Markets for recovered materials are essential for successful recycling. Without markets, materials collected in curbside or drop-off recycling programs end up in a landfill, defeating the purpose of these expensive collection strategies. Lanny Hickman is adamant about the need for markets for recovered materials: "We pick up recyclables and process them. We have to take them someplace - and that's where the disconnect occurs. If there isn't anybody there to take them, then what are we supposed to do? You can't divert the trash stream without developing a market." Unfortunately, predicting recycling markets is somewhat like trying to predict the weather for a year. Recyclers must predict market revenues when they plan new programs or build new facilities - months or even years before recovered materials are ready for sale. One of the most volatile periods for recycling markets occurred between 1988 and 1992. During this period, the amount of recovered materials increased substantially as recycling centers and curbside recycling programs were launched in thousands of communities. Markets were unable to absorb the increase in recovered materials, and prices dropped. Table 5.1 summarizes data during this period. To help address market volatility, many states and the federal government have laws governing the procurement of items made from recycled materials. Even so, recycling markets remain unstable.

Table 5.1 Recycling History: 1988-1992

\begin{tabular}{|l|c|c|c|}
\hline & $\begin{array}{c}\text { \% Increase } \\
\text { in Material } \\
\text { Recovered 1988-1992 }\end{array}$ & $\begin{array}{c}\text { Material t/yr } \\
\text { Recovered on 1992 }\end{array}$ & $\begin{array}{c}\text { \% Change in Price } \\
\mathbf{( 1 9 8 2 - 1 9 9 2 )}\end{array}$ \\
\hline Newspaper & 50 & $7,118,000$ & -74 \\
Corrugated Containers & 24 & $15,376,000$ & -47 \\
Mixed Paper & 37 & $3,976,000$ & -89 \\
Office Paper & 30 & $3,318,000$ & -33 \\
Glass Containers & 142 & $3,637,000$ & -18 \\
Aluminum Cans & 42 & $1,071,000$ & -42 \\
Steel Cans & 213 & $1,135,000$ & -15 \\
Plastic Soft & 136 & & -23 \\
Drink Bottles & & 201,000 & \\
\hline
\end{tabular}

SOURCE: Gregg D. Sutherland of R.W. Beck (February 1995). "Recycled Market Materials History and Index," Denver, Colorado: SWANA, Proceedings of the 6th Annual Waste Reduction, Prevention, Recycling and Composting Symposium, p. 77. 


\section{Corrugated Containers}

Used corrugated cardboard containers are, by volume, the single most recycled material in the waste stream. More than twice as much cardboard is recycled each year than old newspapers, the second most recycled material. Industry and commercial institutions (rather than individual households) recover most of this material for recycling.

In the 5-year period summarized in Table 6.1, recovery of corrugated containers increased by more than 3 million tons, an increase of $24 \%$. A corresponding drop in prices occurred during the late 1980s when prices for cardboard fell to their lowest levels since the early 1970s. Nevertheless, container board mills continued to add recycled fiber capacity. In 1994, the price for used corrugated containers rebounded to an unprecedented high of more than $\$ 80$ per ton, well above its previous high of $\$ 62$ in 1987. Corrugated prices soared to nearly $\$ 200$ per ton in 1995 . It is much cheaper to add recycling capacity than to make corrugated boxes exclusively from virgin materials. Like other recycled fiber products, however, corrugated containers require some virgin materials to maintain product strength.

The volatility of corrugated prices is a good example of how difficult it is to forecast recycling markets. Other materials that saw substantial price increases in 1994 and 1995 include plastic soft drink bottles, newspapers, mixed paper, office paper, and aluminum cans.

\section{Aluminum Cans}

Aluminum, the second most abundant element on earth, is valued for its light weight and great strength. Generally speaking, markets for recovered aluminum have been consistently strong for more than 25 years. The market for recycled aluminum cans was temporarily depressed during the early 1990s due to a glut of virgin material imported from Russia. The high energy cost of virgin aluminum made it unlikely this trend would continue, however. By 1995, the cost of recovered aluminum reached a record high of more than $\$ 1,400$ per ton.

Steel

Steel scrap has strong markets in the United States and abroad. The nation exports 10 million tons of high-end steel scrap each year. California, in particular, has enjoyed consistently strong scrapsteel markets due to overseas demand.

\section{Plastics}

About $2 \%$ of the nation's petroleum and natural gas are used to make plastics. Like aluminum, plastics are strong, lightweight, and relatively inexpensive to transport. Thin composite plastics, made by combining such materials as polyethylene terphthalate (PET) and polyvinyl chloride (PVC), make some of the most efficient, lightweight, and low-cost packaging available. Composites remain difficult to recycle, however. Only PET soft drink bottles and containers made from high-density polyethylene, or HDPE, were widely recycled at the end of 1996.

\section{Paper}

Office paper made from virgin materials is typically less expensive than recycled paper and of higher quality. For this reason, recycling markets for office paper have been slower to develop than markets for newspaper. Since the 1970s, recycled paper has furnished $25 \%$ of the fiber used by the paper and paperboard industry. Recycled fiber has helped meet growing global demands for paper products. Export demand for newspaper is often high. 
Recovered paper prices have been particularly volatile in recent years. After plunging precipitously between 1988 and 1992, they soared in 1994, only to fall dramatically again in 1995. The appearance of regional paper remanufacturing plants, or "mini-mills," around the country may help stabilize prices in the future. Better communication of the availability of recovered materials may help as well. For instance, waste exchanges such as the Recyclers Exchange have been set up on the World Wide Web to provide a way for buyers, sellers, and traders in reusable or recyclable materials to initiate business contacts. The Chicago Board of Trade has set up a similar electronic marketplace for recyclable materials such as office paper and corrugated cardboard. These developments are expected to make recycling more economical and reduce its impact on the environment.

\section{Recycling by Industry}

Many manufacturers recycle production waste. Paper mills, corrugated board suppliers, aluminum sheet manufacturers, steel makers, and glass bottle producers reuse manufacturing waste rather than discard it. Paper trimmings go right back into the pulper; iron spilled when ingots are poured is used to make more steel; broken glass is remelted and reformed; and metal waste recycles continuously through the manufacturing process. Walter (1994-1995) explains the importance of industrial recycling: "A tremendous amount of recycling has gone on in manufacturing for a very long time. In steelmaking [for example], when you pour an ingot of iron, if there are any sprues that form, these are broken off and thrown back into the blast furnace. Today we probably recycle more than $60 \%$ of the iron we use."

Automobile and waste management industries also send large amounts scrap metal back to the steel industry for recycling. Steel left over after car door panels are stamped out is recycled. The "holes" through which workers screw in door handles, latches, mirrors, and so forth go back to the steel maker, not into a landfill. The nation's solid waste combustion plants recover more than 740,000 tons of scrap metal for recycling each year. Such efforts contribute significantly to high steel recycling rates.

The high cost of raw materials is encouraging American industries to design their products with recycling in mind, thus minimizing solid waste. For example, the American Plastics Council has worked with the computer industry on designing computer cases for recycling. The cases snap together so that when they are recycled, they can be readily unsnapped and reassembled into new products. The automobile is designed for recycling, too, thanks to a simple change in manufacturing: auto makers no longer use lead solder, which contaminated scrap metal. Another important development was the invention of the automobile shredder. Alter (1995) recalls: "We used to [put] cars [in landfills] in this country. We chopped them up with axes. Then somebody got a patent on the first auto shredder and started a new industry."

The United States recycles more than 400 million tons of industrial waste-eight times more material than is recovered for recycling from households. For example, the dust produced by electric arc furnaces during steelmaking is a hazardous waste containing a mixture of iron, cadmium, and zinc. Rather than dispose of tons of hazardous waste each year, the steel industry has figured out how to recycle most of it. Alter (1995) explains the process:

Industry collects about 500,000 tons a year of electric arc furnace dust, and recycles about 380,000 tons. When manufacturers first galvanized interior steel panels [with zinc], the scrap industry complained [it] couldn't sell the material. Now they're galvanizing both surfaces. One result is that we are seeing lots of conservation 
because these panels don't rust. And the galvanized scrap is going into furnaces. Pollution control regulations say the dust, which contains lots of iron, cadmium, and zinc, must be collected. Steel companies found it cheaper to recycle it than to dispose of it as a hazardous waste. They do it by volatilizing the zinc out of the dust. They sell about 30,000 tons to Mexico and some to an industry in West Virginia. The system is basically designed for recycling.

Because it is cost effective, industrial recycling is market driven. It occurs outside the political arena, and the public is generally unaware of its importance.

\section{Recycling Methods}

The recycling industry is growing rapidly. As it grows, it is developing better processes for recycling different materials. Materials recovery may include both mechanical and chemical processing of waste materials. Mechanical processing of consumer waste takes place in MRFs and uses many of the same techniques employed by the scrap industry. Separation techniques include size reduction (shredding), screening or trommeling, air classification, and magnetic separation. A number of these techniques, including trommeling, air classification, and source separation, are used to separate plastics from other solid waste.

Screening and trommeling both separate waste by size. In screening, varying mesh sizes are used to segregate waste. Mixed waste is dropped through a sequence of ever smaller screens. A trommel is a large, rotating cylindrical device mounted on an inclined surface. Solid waste is fed into the center of the device on a conveyor belt. Smaller particles fall out of the trommel through holes in the side, while larger pieces are carried out through the top of the device. Air classifiers separate waste with a blast of air, which carries light weight waste, such as paper and plastic bags, out of the top of the classifier as metals and glass fall to the bottom.

Glass recovery systems may stand alone or be combined with nonferrous metal recovery. Manual sorting, screening, air classification, froth flotation, and optical sorting can all be used to separate glass from mixed MSW. Froth flotation was originally developed for processing minerals. During the process, chemically treated glass particles float to the top of liquid containing minerals and other waste particles. Optical sorters reject opaque materials and can be used to sort glass according to color.

Aluminum may be removed from other solid waste by hand picking, shredding, screening, trommeling, air classification, and eddy-current separation. In eddy-current separation, solid waste passes through an electromagnetic field that separates aluminum (and other nonferrous metals) from other solid waste. After aluminum is recovered from the mixture, other metals are separated via magnetic or hand sorting.

Residues left over from sorting can be processed in a sweat furnace to recover zinc. Copper alloys can be sent to copper refiners for processing in blast or open-hearth furnaces before being refined. Aluminum can be recovered through a similar process, but the material is less valuable (because of impurities) than pure can stock.

The scrap industry processes large items, such as railroad cars and automobiles, into metals and other valuable materials. Typically, these larger items are prepared to the specifications of buyers who contract for the materials ahead of time. The scrap industry also processes selected manufacturing waste and surplus materials such as plastics and newsprint to user specifications. 


\section{Paper}

Broadly speaking, paper recycling is the collection and processing of wastepaper for secondary fiber, which the paper industry uses to make new paper products. Secondary fiber, which is produced from manufacturing scrap and consumer discards, is shorter and weaker than fiber from virgin pulp. For this reason, many recycled paper products contain both recycled and virgin pulp. However, boxboard and lower quality recycled papers often consist entirely of recycled fiber.

The removal of contaminants such as inks, adhesives, and coatings from wastepaper poses a major challenge in paper recycling. Dirt, glass, sand, paper clips, and other materials must also be removed before remanufacturing. The latter are often removed by screening or other mechanical processes. As methods for removing contaminants are improved, more paper can be recycled.

\section{Boxboard}

The technology for making boxboard was developed in 1905. Wastepaper is dumped into a pulper, which is essentially a huge blender. Wires used to wrap the paper bales get tangled around themselves and are removed from the center of the pulper. Waxed paper, heavily printed cardboard, and other materials that do not pulp readily get trapped in the wires and are removed along with them as waste. The paper fibers left behind in the pulper are processed and dried to make boxboard. In 1995 , more than $95 \%$ of boxboard was made from recycled paper.

\section{Newspapers}

New flotation technology has improved the efficiency of turning old newspapers into new newsprint. The technology uses clay, which attaches to bubbles. As the bubbles float up through the pulping mixture, particles of ink and dirt adhere to them. Because ink and dirt are removed, the cleaned fiber can be remanufactured into newsprint. The new technology is sometimes combined with older washing systems.

\section{Corrugated Containers}

Recent improvements to container board technology include a fiber fractionation process, which increases the strength of recycled cardboard and minimizes its weight. Another improvement is an industry wide move toward using recyclable wax. In the past, paper mills were reluctant to accept waxed cardboard containers for recycling. The wax was difficult to clean and created imperfections in finished products. The mandated use of recyclable waxes is expected to boost recovery of used cardboard containers.

Some mills have begun using mixed paper in lieu of old corrugated containers in the manufacture of new corrugated containers. This recycling method received a boost in 1996 when the U.S. Post Office began a program to collect mixed paper from undeliverable junk mail.

\section{Office Paper}

Recycling of high-grade office paper is relatively new. New methods are under development as a result of efforts by government agencies and commercial institutions to recover substantial quantities of office paper. A potential problem for recycling office paper is the contamination of recycled fibers with groundwood. Groundwood contains lignin, which fosters paper decay. The substance is normally found in newsprint and can find its way into recycled office paper, reducing the quality of the paper, which is normally lignin-free. 


\section{Glass}

Recovered glass is used as a raw material for making new glass containers, daily cover in landfills, and pavement (asphalt). Because glass is heavy and transportation costs are high, crushed glass is being increasingly used in the latter two applications.

Large amounts of recovered glass that are suitable for melting are called cullet. If cullet is destined for remanufacturing of containers, it is usually separated by color. Most bottlers want either clear or amber glass for their containers. Few American companies produce green glass, making it particularly difficult to find markets for recovered green bottles imported from Europe.

\section{Aluminum and Nonferrous Metals}

Because large amounts of energy are needed to extract and refine the most widely used nonferrous metals (aluminum, copper alloys, lead, and zinc), they are less expensive to recycle than to make from virgin materials. Consequently, they tend to be used only when necessary in long-lived products. When their useful life ends, significant amounts of these metals are recovered for recycling.

Nonferrous metals represent only a tiny fraction of mixed MSW. For example, lead-acid batteries are removed from nearly every dismantled automobile for recycling rather than being discarded. About $75 \%$ of aluminum cans are recovered for recycling.

\section{Steel}

Steel is the most recycled material in the world. In 1994, the United States recycled 66 million tons of it. Steel is recovered from many sources, including construction and demolition firms, automobile manufacturers, discarded cars and appliances, recycling programs, and waste-to-energy plants. Recovered steel is processed through an infrastructure of ferrous scrap dealers. Steel's magnetic qualities make it easy to sort, handle, process, and recycle. Since recycling steel is an integral part of steelmaking, the use of recycled scrap lowers the cost of producing new steel.

Basic oxygen furnaces, which produce rolled, flat sheets for making cans, cars, and appliances, use $25 \%$ to $30 \%$ steel scrap. Electric arc furnaces, which produce heavy steel construction materials, use manufacturing waste and scrap almost exclusively. Foundries, which produce such products as engines and machinery parts, use about $75 \%$ recycled scrap. Between $66 \%$ and $68 \%$ of the steel produced each year in the United States is made from recycled scrap metal (Heenan 1996).

Regardless of their recycled steel content, steel products can be recycled again and again - essentially forever. Bridges, guardrails, road signs, fire hydrants, construction materials, cars, trucks, heavy machinery, desks, file cabinets, and cans are products that contain recycled steel, which can be recycled. The nation's steel industry has been recycling steel scrap for more than 150 years.

\section{Plastics}

Some waste plastic is recycled, chiefly PET and HDPE containers marked as 1 and 2, respectively. Some industrial plastic waste is also recycled, particularly thermoplastics. Thermoplastics include PET soft drink containers, most plastic packaging, and a substantial portion of plastic used to make automobiles and other durable goods. Once separated, plastics are heated to be reformed. Chemical stabilizers are sometimes added to the melted plastic before remanufacturing. Thermoplastics can be reheated and reformed several times, making them good candidates for recycling. 
Recycled plastics are becoming widely used in construction. Eventually, at least half the thermoplastics used in new homes will use recycled materials (Kirk-Othmer Encyclopedia of Chemical Technology 1991). Plastic lumber made from milk and detergent containers and industrial scrap is now used for decks, fences, and other exterior applications. Carpet and fiber companies represent a growing market for recycled soft-drink containers, which can be reprocessed into carpeting or insulation.

\section{Composting}

Composting has been practiced for centuries. Farmers and gardeners do it by combining food waste, paper, leaves, grass clippings, or cardboard with soil and a little water in an outdoor bin. Home-style composting schemes have been practiced throughout this century. Small composting systems work fairly well with a combination of wet garbage and dry matter such as leaves or wastepaper. How well composting works depends upon the temperature inside the compost pile, its moisture, and the amount of air available to microorganisms. Composting occurs in the absence of air but produces foul odors. To control these odors, most people strive to keep the waste exposed to air. Over time, the mixture undergoes biological processing into a humus-like material that can be used as a soil conditioner. Because compost contains only small amounts of nitrogen, phosphate, and potassium, it is not a fertilizer. If desired, compost can be enriched with sewage sludge or chemical fertilizers to make it more suitable for growing crops.

Since the 1920s, researchers have undertaken a number of projects to develop engineering techniques for making compost from MSW. The oldest successful MSW composting plant began operation in Altoona, Pennsylvania, in 1950. Initially, the plant used the windrow method, in which solid waste is deposited outdoors in rows and turned at regular intervals to keep it well aerated. In 1963, the plant began using the more complex Farfield-Hardy method. The method first removed metal, glass, and other noncompostible material from the waste. Then, the solid waste was wet pulped to reduce its size before being digested in a large tank. For many years, Altoona collected food waste for the plant, which sold compost all over the East Coast. Eventually, the market for compost dried up, and the plant was closed.

Two comprehensive federal composting research projects took place in Gainesville, Florida, and Johnson City, Tennessee, during the late 1960s and early 1970s. The Gainesville demonstration project operated a high-rate digester from 1968 through 1971. The Johnson City project focused on the windrow composting method and ran from 1966 through 1971. It was cosponsored by the U.S. Public Health Service, TVA, and the city.

The Johnson City project demonstrated that composting could effectively recycle organic waste back into soils without causing pollution. However, it also showed composting to be far more costly than either landfilling or incineration for solid waste management-whether or not the compost product is sold to help pay for costs. Alter (1995) believes the Johnson City compost experiment settled the debate over whether MSW composting would ever be economical:

The Johnson City compost experiment was a benchmark in history. It was the first big compost plant that didn't work. Then there was a second, a third, a fourth, a fifth. I used to kid Carlton Wiles [the USPHS project engineer] that it was one of the best documented economic failures in the United States. Nobody's going to compost mixed MSW. It's [far] too expensive, and they won't know what to do with the compost when they get it. 
Carlton Wiles (1995-1997), now at NREL, agrees: "Even though we closed down the compost experiment in Johnson City in 1970, we had originally planned to stay open a few more years. We were going to build a materials separation facility. But it was taking a third of EPA's solid waste research budget to operate the compost plant, and it just wasn't worth it. By then it was clear that we weren't going to be able to sell the compost."

\section{Municipal Composting Systems}

In the mid-1980s, there were five operational compost systems in the United States. The Delaware Reclamation Plant, the largest of the five, began operation in 1984. The facility made pellets from paper and plastics and removed glass and metals from the waste before co-composting it with sewage sludge. In 1995, about 21 cities and counties had mixed-waste composting plants.

The mixed waste composting facility at Sevierville, Tennessee, is typical of newer facilities. The plant processes 150 tons per day of MSW and 75 tons per day of sewage sludge in three rotating drum digestors. After digestion, inorganic materials such as plastics and steel cans are removed by trommel screens and a magnetic separator. The remaining material cures for an additional 4 to 6 weeks in piles on the floor of an aeration building. There, air is forced through the piles to keep them well oxygenated and to regulate temperature. At the end of this step, the finished compost is screened and refined into a finished product. The composting facility is part of a county-wide integrated waste management system that also includes recycling and landfilling. The facility regularly receives a small number of complaints regarding foul odors, particularly during warm weather.

\section{Market Issues}

Even though composting has been technically feasible for a long time, its costs continue to run higher than those for other management options. Wiles (1995-1997) explains why he is skeptical that mixed-waste composting will play a major role in future MSW management:

We keep making the same mistakes over and over again. Cities go into composting thinking they're going to make money. They find out they're not; in fact, it's costing them money, because they can't sell the compost. Usually, they have no plans about what to do if they can't sell it, so they're left with piles of compost. They have to pay to dispose of it.

The only successful composting programs I know of are those that mandate that the community use the compost on parks and city grounds or that have a specialty market such as local farmers who agree ahead of time to take the compost for free.

The major barriers to mixed-waste composting are concerns regarding odors and market acceptance of the compost product. Market acceptance is not only a matter of the compost's relatively high cost - a significant issue in its own right. The current lack of product specifications also does little to encourage the public to buy the product or to allay concerns regarding its safety. Walter (1994-1995) explains why consumers are less than enthusiastic about buying compost:

What you want to produce is what your market demands. Not long ago, I was in my local store. There was a bag of "milorganite" about 3 feet long, 2 feet wide, 6 inches high, and weighing 50 pounds. It cost $\$ 4.99$ and contained less than $1 \%$ nitrogen, $1 \%$ 
potassium, and 1\% phosphorus. Right next to it was a bag about 18 inches long, 12 inches wide, about 6 inches high, and weighing 30 pounds. It cost $\$ 1.99$ and contained $10 \%$ nitrogen, $10 \%$ phosphorus, and $10 \%$ potassium. I can tell you, I didn't buy the organite despite any trace minerals it had, because I got fewer nutrients and it cost two and a half times as much.

In contrast to the United States, such countries as Germany and the Netherlands have a long history of composting significant amounts of source separated, biodegradable solid waste. These countries use the compost products for specific purposes such as vineyards or tulip beds.

\section{Composting Methods}

There are three basic methods for commercial composting: mechanical, co-composting, and windrow. In mechanical composting, machines such as drums pulverize, turn, and aerate the compost. With this method, decomposition and stabilization take between 5 and 10 days if temperature and moisture content are well controlled. The compost product is often left to cure for several weeks or even months before being used. Mechanical composting is expensive but produces fewer foul odors during processing because it is easier to control than the other two methods.

Co-composting of solid waste and sewage sludge disposes of two types of municipal waste at the same time. The waste is mixed in set proportions, then allowed to compost. Fish waste, chicken waste, or horse manure can be used in lieu of sewage sludge.

In windrow composting, solid waste is piled outdoors in rows with lanes in between them. The windrow method conserves heat and moisture better than the other methods. Windrow composting can take anywhere from 2 to 10 weeks. Most yard waste composters use low-tech, inexpensive, open windrows with mechanical turning for aeration.

Several factors, including size, orientation, and spacing, are important in proper windrow formation. If the windrows are small, it is easier to keep the pile well aerated, which reduces foul odors. Aeration helps control moisture and temperature. Windrows are aerated either by blowers or by mechanical devices that mix the piles.

Outdoor composting takes place on a very gradual slope to ensure good drainage and prevent puddles from forming. Windrow spacing is often determined by the type of turning equipment. Equipment operators try to avoid driving directly on the piles and take care to gently apply material onto the piles.

Many modern composting systems may combine aspects of the basic methods. For example, one Colorado company has had good luck co-composting pulverized construction waste with wastewater from a local brewery. The facility uses a low-tech, mechanical windrow method.

Composting works best when food waste is separated at the source. Source separation has the advantage of leaving the remaining mixed solid waste much cleaner. It is easier and more costeffective to recover other materials for recycling from relatively clean mixed waste at a materials recovery facility.

\section{Mixed-Waste Systems}

Mixed-waste composting systems vary with respect to cost and processing time. Unless composting conditions are rigorously controlled, it is particularly difficult to control odors and destroy germs in these systems. (Germs are less likely to be present in yard waste or home composting systems that exclude animal food waste.) 
Most composting systems employ four basic steps: First, solid waste is prepared for composting by removing any household hazardous waste such as paint or motor oil. Source separation is preferable, but composting facility operators also use mechanical screening and handpicking to ensure the removal of such materials. Pesticides and other chemicals can interfere with biological processing.

Next, solid waste is shredded to make particles about 1 to 2 inches in diameter. Hammermills, shear shredders, rotary drums, and screens may be used to create uniform particles. Small, similarly sized particles promote microbial activity, ensure maximum decomposition, and reduce the contaminants in the waste mixture. At this point (if not earlier), metals, plastics, glass, and other inorganic materials are removed from the waste either before the initial digestion phase or afterward. Trommel screens and magnetic separators are commonly used for this step.

Yard waste or sewage sludge may be blended with solid waste that can be composted. During the mixing step, facility operators adjust the proportions of carbon and nitrogen present in the mixture. High volumes of carbon-rich wood or paper waste may necessitate the addition of nitrogenrich sewage sludge or manure. Moisture is also added to encourage microbial action. The ideal moisture content for composting ranges from $45 \%$ to $60 \%$.

Composting occurs in three distinct phases: active composting, stabilization, and curing. During active composting, microbes rapidly decompose waste so long as adequate nutrients, moisture, and oxygen are present. During active composting, it is important to monitor temperature, moisture, odor, color, and texture.

Temperature gives an indication of oxygen levels, moisture levels, and when it is time to turn the pile. When composting begins, temperature often rises quickly and then is usually controlled to between $40^{\circ}$ and $50^{\circ} \mathrm{C}$. This range effectively destroys disease-causing organisms while promoting decomposition. Temperature control is managed by blowing air through the mixture, and, to a lesser extent, by turning the material and adjusting pile size.

Moisture should be controlled to sustain microbial activity. If the mixture is too dry, microbial activity slows or stops. If the mixture is too wet, oxygen in the mixture may become depleted, encouraging the growth of microorganisms that live without oxygen (anaerobic bacteria). Moisture can be controlled by adding water to the composting mixture and mixing it thoroughly. Blowing more air through the mixture and turning it more frequently promote evaporation and help dry out the mixture. Finished compost should have a moisture content of about $40 \%$. If it becomes drier, it can be difficult to remoisten and creates dust.

Compost should feel moist and have a loose, chunky texture. If the compost is fine or sticks together, more dry, bulky material may be needed. A rotten-egg smell suggests the pile lacks oxygen and has become anaerobic. Anaerobic decomposition produces corrosive acids that can harm plants. It also increases odors and produces other undesirable products.

During stabilization, composting continues more slowly. The compost is often considered stable as soon as it can be stored or added to soil without producing odors, attracting pests, or harming soil. ${ }^{27}$ If compost is added to soils before it reaches stability, composting will continue, removing nitrogen from the soil and possibly harming plants. If incompletely composted material is bagged and sent to stores, it may sour as chemical and biological reactions continue. 
Curing facilitates the long-term stability of compost. If compost is aerated during curing, the product matures as microbes slowly convert any remaining organic material into carbon dioxide and humus. Curing takes place over several weeks.

The final compost product is screened to remove glass, metals, plastic film, stones, bones, leather, and plastic. Mature compost should have no odor and a rich, dark color. It should not be possible to recognize any specific components such as grass or leaves.

\section{Facility Management}

Compost facilities must control odors, dust, vermin, noise, and litter. Most odors from composting are a result of the process itself, particularly when too little oxygen is present in the mixture. Proper design and operation of the composting facility is essential for controlling odors. However, effective odor control may require special techniques for removing foul-smelling compounds. These include wet scrubbers, biofilters, chemical treatments, and incineration.

It is important to minimize dust and run-off from the facility, especially the liquid (called leachate) that forms in poorly maintained windrows. Proper windrow management is the best way to prevent leachate formation. The best way to control dust is to keep incoming waste and compost moist. Activities that help control dust include enclosing and ventilating dusty processing areas, properly controlling moisture during processing, paving the site's roads, and keeping the facility clean.

Insects and animals may be attracted to a composting facility by odors. Since these creatures can spread disease by carrying germs outside the facility, they must be controlled to protect the public health. Methods for controlling vermin include cleanliness, chemical and biological sprays, and traps. Stagnant water should be avoided to discourage mosquito breeding.

Noise and litter bother employees, customers, and neighbors of a composting facility. Noise can be controlled by operating equipment correctly, enclosing noisy equipment and processing areas, and providing earplugs for employees. Litter can also be controlled by enclosing processing areas and installing fences around screening areas, packing areas, and the entire facility.

\section{Yard-Waste Composting}

Since 1986, several states have banned leaves and other yard waste from landfills, an action designed to prolong the life of landfills. As a result, significant amounts of yard waste are being composted. The success of yard waste composting programs is responsible for a substantial fraction of the increase in recycling that took place between 1986 and 1994. Yard-waste composting costs much less than mixed-waste composting.

As of 1995, there were more than 3,200 centralized composting and mulching programs across the United States. Five states, including Minnesota, Massachusetts, New York, Ohio, and New Jersey, had more than $40 \%$ of the programs to divert yard waste from landfills. Home composting may also be helping minimize landfilling of yard waste, but there is no reliable method for determining its impact.

Thus far, the enthusiasm for yard-waste composting as a waste diversion method has not been matched by a corresponding growth in markets for composted products. Because of low market demand, compost is expensive. With a market price of about $\$ 22.50$ per ton, compost is worth more as a fuel in a waste-to-energy plant than as a soil enhancer.

Yard-waste composting methods include community composting, land application, and mulching. In community composting, centralized facilities compost grass clippings with leaves or 
brush. The mixture of wet and dry material helps control moisture and temperature, yielding a higher quality product.

Leaves may be piled on the ground during the fall without being composted. They function much like mulch during the winter, providing insulation and keeping soils moist. With the arrival of warmer weather, the leaves break down, conditioning the soil.

Old Christmas trees, tree branches, and other woody yard trimmings may be chipped or shredded, then sold or distributed as mulch for landscaping and gardening. Mulching involves very little management and virtually no biological activity. It is relatively simple and inexpensive.

\section{Home Composting}

Home composting systems come in several varieties. Many use a bin made of chicken wire, scrap wood, or cinder blocks with enough space inside the bin for air to reach the pile. Walter (1994-1995) recommends building a compost bin well away from trees, wooden fences, or other flammable materials, just in case the digestion process gets too hot: "My father-in-law built a compost pile around the base of a tree. It got so hot, it set the tree on fire."

Many foods can be composted, including vegetable trimmings, eggshells, coffee grounds (and filters), and tea bags. Leaves, grass, and yard clippings (if they are mulched to a manageable size) also make good compost. A number of other items can be added to a home compost pile, including paper towels, vacuum cleaner lint, wool and cotton rags, sawdust, shredded newspaper, and fireplace ashes. However, meat, dairy foods, fat, oil, and grease are not suitable for home composting. These foods attract pests, and meat promotes the growth of dangerous germs during processing.

Home compost piles should be turned every few weeks to distribute moisture and circulate air through the pile. Air discourages the growth of the anaerobic organisms that cause foul odors. It takes about 3 to 6 months to make compost. During this time, the pile may get quite warm and even attract earthworms. Once the compost is stabilized, it can be spread in the garden or lawn. Properly cured compost also makes good potting soil for house plants.

\section{Profile: George Trezak}

George Trezak played an important role in the history of materials recovery. In 1968, he was a young professor of mechanical engineering at the University of California at Berkeley looking for something "relevant" to do in technology development. A five-part series in the San Francisco Chronicle on solid waste problems led him to visit the Oakland landfill; that visit inspired him to began a MSW research program: "I was blown away. The place had about 80,000 birds. It was ripe for some new technology. So I sent a letter to the U.S. Public Health Service. I had this idea of putting together an automated garbage sorting machine that would sort waste by categories. I thought it would be a great master's degree project for one of my students." Trezak recalls that the U.S. Public Health Service thought the sorter was a good idea. The agency also wanted help in designing better shredders for composting plants. By 1969, Trezak had a grant to evaluate shredder designs.

When a federal composting project at Johnson City, Tennessee, was halted and EPA's Cincinnati lab underwent severe budget cuts in 1973 and 1974, Trezak was able to acquire key equipment from several projects. He remembers: "In 1971, I told EPA we needed a lab setup here with a shredder so we could do experiments with real garbage. Eventually, they let us move the shredder from Johnson City, Tennessee, to the University of California's Richmond Field Test 
Station. The station was off campus - a good place for a garbage lab. We got the shredder up and going so we could play with different wastes." Trezak used the equipment to establish a program at Berkeley in MSW processing. Wiles (1995-1997) believes the nation's solid waste management programs reaped significant benefits from Trezak's research:

When EPA decided it just wasn't worth the money it was costing to keep the Johnson City project going, George Trezak got some of the equipment. He was a young engineer at that time. I remember him measuring a big shredder we had, trying to figure out how he could get it out of the building so he could take it.

George went on to do most of the basic research on shredding MSW. He developed most of the concepts in use today. Size reduction was a complex and tricky problem, both in terms of the hardware you need and in terms of developing a process to reduce the volume of MSW.

Trezak's work on trommel screening led to a commercial trommel screen design that is widely used today. Trezak (1995), who worked on solid waste sorting for about 10 years and then shifted his research focus to hazardous waste, recalls: "For about 10 years, every time EPA needed something tested, they'd call me. In the early 1980s, I shifted into hazardous waste right along with EPA. I developed a new polysilicate technology for treating incinerator ash. The technology keeps heavy metals from leaching out of it and polluting the environment. The method works with auto shredder residues and ash from waste-to-energy plants."

Trezak retired from his post at Berkeley in 1990 to work on projects to improve wood and yard waste processing, to improve the sorting lines in MRFs, and to develop a state-of-the art plastics recycling facility. In conjunction with the plastics project, Trezak is developing a method for recycling plastic grocery bags and other plastic films. He picked the project because plastic films, which do not degrade in landfills, are often a nuisance. 


\subsection{Energy Recovery}

Nearly all technical trends are toward new devices and modes of production that are more efficient, use fewer resources, produce less waste, and cause less ecological destruction than technology of the past. ${ }^{28}$

Solid waste can be an important energy resource. It is abundant, domestic, and renewable. Americans could get more than $3 \%$ of the electricity ${ }^{29}$ they use each year from solid waste, if energy recovery was made a national priority. Interest in developing energy recovery technologies heightened during the 1970s and 1980s, but waned in the 1990s.

Although many waste-to-energy facilities were built during the $1980 \mathrm{~s}$, the public was ambivalent about this method of managing solid waste. Environmental groups, in particular, were concerned about emissions from waste-to-energy combustion. Their concerns persisted even after federal regulations made energy recovery from waste one of the cleanest power production technologies available. Waste-to-energy combustion inherited fallout from long-standing problems associated with incineration. ${ }^{30}$

There are two basic methods of recovering energy from waste: biological processing and combustion. Biological methods use microorganisms to change waste into high-energy products such as biogas or alcohol fuel. ${ }^{31}$ Combustion of waste produces heat, which can be used to warm water or to make steam. Hot water and steam may be used directly for industrial processing or district heating. In most cases, however, steam is used with turbines to generate electricity, which is a particularly valuable form of energy. Electricity made from solid waste displaces electricity made from coal, reducing the impact of power generation from fossil fuels on the environment. The generation of electricity from waste produced fewer emissions than coal-fired generation even before EPA issued its stringent air emissions standards and guidelines for MSW combustion in 1996.

\section{Combustion}

The history of waste-to-energy combustion goes back to the 1700s in England and the United States. Old newspapers were used to light coal (or wood) stoves used for heating or cooking. Rather than being discarded, vegetable oils were used in lamps. England, Germany, and Japan pioneered the use of RDF during the late 1800s. England began burning refuse for fuel in 1874 in Nottingham. In 1876, the English added a steam boiler to a garbage incinerator, which was known then as a "crematory." The facility was used to generate electrical power in Leeds. A more advanced design

\footnotetext{
${ }^{28}$ Easterbrook, Gregg (1995). A Moment on the Earth. New York: Viking Penguin, p. xvi.

29 Three percent of the electricity produced in the United States would be enough to power about eight million
} homes.

${ }^{30}$ Incineration was used to reduce the volume of MSW for more than 100 years in many American cities. Incinerators usually did not recover energy and emissions were not controlled. They were notorious for blowing trash, foul odors, and emissions of black smoke. Because they were located in the heart of cities, pollution from them had a great impact on many people.

${ }^{31}$ Not all biological processing methods for MSW recover energy. For example, composting in the presence of air uses additional energy in changing the chemical energy in waste to heat. 
was installed in Birmingham in 1887. German engineers experimented with fuel cells for power generation in Berlin and Hamburg during the 1880s. In 1897, the Japanese built RDF plants in Tsuruga and Osaka to recover heat and steam power from waste. Similar American experiments during the late 1800s and early 1900s were not as successful. Early American RDF plants worked poorly because they relied on waste that had undergone little or no prior processing.

The U.S. Army built the nation's first garbage incinerator on Governor's Island in New York harbor in 1885. The same year, the city of Allegheny, Pennsylvania, built the first municipal incinerator. Within 2 years, Wheeling, West Virginia, and Des Moines, Iowa, had also installed crematories. Crematories borrowed heavily from European incinerator technology, which did not work very well with American solid waste because it was too wet to burn efficiently. Numerous cities discovered this problem too late - after building a new incinerator. Incinerators had obvious drawbacks, according to Don Walter 1994-1995), formerly of DOE:

They smelled bad, belched black smoke, and [attracted] rats. Through the 1920s, an incinerator was run by a city group whose job was to cram as much waste through it as they could. So [the incinerators] were not very sanitary because they weren't run well. And, frankly, that's why I think the recyclers love the word "incinerator." They're playing on old cats like me who understood those things belched smoke and smelled awful. Oh, they were terrible. They deserved to be shut down when they were.

Incineration offered several advantages over open dumping, however. A significant portion of a community's solid waste was converted to ash. The smells, although unpleasant, were considerably less pervasive than when solid waste was deposited in open dumps. Incineration kept vermin under control and destroyed germs in solid waste. Steve Levy (1995) of EPA explains why cities chose this disposal technology:

As cities filled up, it got harder to find a hundred acres in the middle of town where you could have a dump. And if you did have one, people didn't want it because of the smell and the open burning. The choice was between building an incinerator and hauling trash further and further out to dump it. But you couldn't haul the waste very far in the 1930s, 1940s, and 1950s. There was no infrastructure. Garbage trucks were small. There were no interstate highways. Streets were smaller. To go 10 or 12 miles out to a landfill was too far for a truck to go. They couldn't get there and back in time to do enough collection.

Cities needed to build something close that didn't take up as much space as a landfill. You could put an incinerator on two acres in an industrial area or poor part of town, and it would be close to where the waste was collected. The trucks could get there, unload, and get back on the streets.

Incineration soared between 1910 and 1920, then leveled off until the late 1930s. Between 1938 and 1966, the number of municipal incinerators fell from nearly 700 to about 265 . Because of poor emissions control and problems with the buildup of melted glass (slag), incineration declined in popularity as competition from landfills increased. Levy (1995) describes how slagging and other technical difficulties wreaked havoc with incinerators: 
Until the 1920s and 1930s, glass bottles came with corks and ceramic tops. They were intended for reuse. But as the country became more affluent and [glass] could [be made] cheaper, the waste stream started to include a lot of glass, which was a problem for incinerators. As the glass was burned, it melted and coated the tubes, causing mechanical problems.

Back in the 1920s and 1930s, they didn't have the technology to deal with this problem. Companies didn't build incinerators. They made brick and boiler tubes, or they sold cement and steel tubing. A consulting engineer would sit down and design an incinerator the same way he would design a school or an office building. The engineer who built the sewer plant the year before would design an incinerator and specify the grate, the bricks, and so forth, [and] then design the whole thing. Some worked better than others.

Before the 1960s, engineers didn't have anywhere to go to school to learn how to design incinerators. There were no textbooks to [learn] about slagging or corrosion problems. There were no companies like Ogden or Wheelabrator that built these systems. There was no science, no research to say, "Gee, if we'd made the furnace two feet higher and a foot narrower we'd have gotten better temperature control."

Early American experiments with waste-to-energy did not fare well. Before World War I, New York City, Milwaukee, Minneapolis, Seattle, Rochester, Miami, and Savannah built and operated waste-to-energy facilities, but without notable success either technically or financially. In 1905, for example, New York City launched a project to combine a rubbish incinerator with an electric lighting plant. The project was supposed to illuminate several city structures and the Williamsburg Bridge, but little came of it. By hand, workers removed paper, cardboard, rags, iron, and glass from solid waste traveling along conveyor belts. The remaining waste was burned to generate steam to operate the conveyors, heat the building, and light the bridge. Recycling appears to have been far more profitable than energy recovery, which was plagued by technical problems.

The idea of processing solid waste into a denser, more manageable fuel dates back to 1917 . That year, Texan E.L. Culver patented a method for making "oakoal," a compacted refuse brick. Culver's technique was derived from a process for densifying sawdust for fuel by heating and compacting it. About the same time, the English began using an RDF briquette made from "coalesine," a form of pulverized refuse. By 1924, an unknown British sanitary engineer had designed a refuse processing plant complete with trommel screens, shredders, and an air classifier to recover materials for recycling and produce a denser, higher value RDF. It is not clear whether the plant was actually built (Alter 1987).

Atlanta, Georgia, had better luck with waste-to-energy conversion than many cities. In 1924, the city began selling surplus steam from its incinerator to the Atlanta Gas Light Company. The following year, the city burned 126 million pounds of refuse and generated 79 million pounds of steam. The utility purchased about $80 \%$ of it. Two years later, Atlanta built another incinerator adjacent to the first and began selling steam to the Georgia Power Company. Between 1925 and 1935, Atlanta's refuse increased by $30 \%$. At the same time, revenues from waste-to-energy conversion rose $138 \%$.

Despite occasional success stories, waste-to-energy's high costs deterred significant development of the technology until the 1970s. Levy (1995) summarizes the situation: "People 
viewed incineration as a means of garbage disposal, not as a means of energy recovery. Energy was cheap, and we were making great strides in hydroelectric power and fossil fuel combustion. Public works directors who saw waste as having value as a fuel were the exceptions." Incineration, ocean dumping, and landfilling were all less expensive ways to manage solid waste disposal than energy conversion. Coal, oil, and natural gas were plentiful and much less expensive resources for producing steam or electricity than solid waste. These factors worked against the significant development of waste-to-energy technologies until 1973 when concerns about the environment and the nation's energy security led to renewed attention to waste-to-energy conversion. Nevertheless, according to Levy, there were still problems to solve:

With the Arab oil embargo of 1973, utilities [were] willing to discuss energy recovery from waste combustion as part of the long-term need to develop alternative sources of energy. But there were [many] institutional problems to solve. Utility customers wanted energy when they flipped a switch. People worried about what would happen if there [was] a garbage strike and the garbage didn't [get] to the waste-to-energy plant or what if a boiler slagged up and went down? If these things happened, the utility would be out of its primary business - selling energy. [The] business [of utilities] wasn't getting rid of waste.

Utility concerns were addressed during the 1970s and 1980s as more facilities were built and waste combustion technologies and methods improved. During this period, American technology development profited from innovation that had already occurred in Europe. European nations began actively developing waste combustion technologies around the 1920s. With less land, more expensive fossil fuels, and sizeable district heating requirements in many cities, countries like Germany and Switzerland had greater incentives to develop waste-to-energy systems. Until about 1950, most European waste-to-energy plants used refractory-lined chambers to control the combustion process and used waste heat to heat water to recover energy. The Europeans began adding pollution controls to waste-combustion plants during the 1940s and 1950s.

About 1950, the Europeans began adapting coal-based technology for waste combustion. By the time the United States was ready to explore waste to energy, the Europeans had been operating modern, efficient waste combustion plants for at least 15 years. Levy (1995) explains why the European approach to solid waste management evolved so differently from that in the United States:

After World War II, European countries had to rebuild a lot of infrastructure [e.g., heat, electricity, and water] from scratch. They were densely populated, and they didn't have much available land. They wanted to get rid of trash close to cities. They didn't have land available for landfilling, and they didn't have the roads for hauling waste long distances.

So they chose the incinerator route. They put more engineering into [incineration than the U.S. did]. They incorporated energy recovery more quickly because many cities relied on centralized, district heating systems. In cities like Frankfurt [Germany], they would build a central heating plant, then lay the infrastructure for distribution along with the new roads and sewers. They built incinerators right in the center of town because that's where they had cleared the land. 
The Europeans had problems with the first incinerators they built-combustion problems, corrosion problems - but they knew what they needed and went out and perfected it. They didn't look for new technologies because they didn't have all the scientists and a national research program like we did in the United States. All they had were cities and engineers building stuff that wasn't working right, so they solved a lot of problems and got waste combustion to work much better. In the 1970s, the Europeans were perfecting energy recovery from waste combustion - the combustion process, the air pollution controls, the energy recovery, the boilers, and so forth.

The military pioneered modern waste-to-energy combustion in the United States. The U.S. Navy built new waste-to-energy plants at the Norfolk and Portsmouth, Virginia, naval stations in 1965 and 1970, respectively. The facilities were equipped with two boilers, each designed to burn about 180 tons of solid waste per day. When fully operational, each plant produced about 50,000 to 100,000 pounds of steam per hour. The Norfolk plant was the first in the United States to employ a waterwall combustion furnace, originally developed in Europe for coal and adapted to solid waste. Steam produced by the facility was routed to the navy's steam plant in Norfolk. The steam was used on ships under repair whose boilers were shut down.

The U.S. Army and U.S. Air Force also conducted early experiments in waste-to-energy combustion. The U.S. Army Corps of Engineers Research Laboratory at Champagne, Illinois, evaluated a small, multi-chambered combustor to burn solid waste and produce steam for district heating. At Florida's Wright-Patterson U.S. Air Force Base, military researchers studied processes for making pellets derived from waste to burn in coal-fired boilers.

\section{The Waste-to-Energy Industry: 1970-1979}

The 1970 Clean Air Act opened the door to the development of a U.S. waste-to-energy industry. Under the Act's authority, open burning dumps were banned. Operators of garbage incinerators were forced to install costly pollution controls or shut down. In 1970, only about 160 incinerators remained in operation. However, they accounted for a significant amount of air pollution. Some of them were plagued with rats, odor, and blowing paper and ash. Public opinion, bolstered by the new law, forced the closure of the dirtiest and most polluting of the old-style incinerators. The loss of incineration forced municipalities to look seriously at waste-to-energy conversion.

\section{Chicago's Northwest Garbage Incinerator}

About 1970, the city of Chicago began looking at innovative incineration technology for its new northwest facility. Concerned that imminent air quality regulations would make conventional technology prohibitively expensive, the city selected a European waterwall design that used electrostatic precipitators for emissions control. Electrostatic precipitators provided the most advanced air pollution control available at the time. The new plant, which was designed to process 1,600 tons of trash per day, began operations in January 1971. A federal grant subsidized part of the plant's \$23 million cost. At the time, the Bureau of Solid Waste Management anticipated using the facility as a demonstration project to establish new incinerator guidelines. However, this did not happen. Instead, Chicago built and operated the plant. Several years after the incinerator was built, a steam export line was added, allowing the facility to recover energy. The steam was used to power plant equipment. Extra steam was sold to the Brach Candy Company. 
The city purchased equipment for the new incinerator from private companies. The grate and ash handling systems were manufactured by West Germany's Martin Company. Martin's selection opened the U.S. market to an important European firm and helped set the stage for the development of mass-burn technology in the United States. Mass-burn systems combust solid waste that is taken directly off garbage trucks and put in huge furnaces. From an engineering standpoint, they are simpler and less expensive than other technologies, which prepare the MSW to improve its quality as a fuel. This is one reason mass-burn systems have dominated the U.S. waste-to-energy industry since the 1970 s.

The use of European technology in the Norfolk and Chicago plants reshaped the waste combustion industry in the United States. By 1975, Harrisburg, Pennsylvania, and Braintree, Massachusetts, had built waste-to-energy plants using Martin grate and ash handling technologies. Whereas old-style incinerators had been built by local engineers ordering components from different manufacturers, U.S. companies (with licenses for European technologies) began building and operating complete waste-to-energy plants. This development parallelled what had taken place in Europe during the 1950s and 1960s, according to Levy (1995): "Several key companies emerged in Europe as waste-to-energy companies. Instead of there being one company that sold a grate, another that sold brick, and another that sold control panels, one company built the whole system from 'chute to stack,' as we say. Companies like Martin built, packaged, and sold systems to cities that needed them. They improved their product every time they built a plant."

\section{The Saugus Plant}

In November 1975, a new waste-to-energy facility began operation in Saugus, Massachusetts. The plant, built by Wheelabrator-Frye, used a grate system designed by Von Roll, Ltd., a Swiss firm. Like the Martin Company, Von Roll was a well-established European incinerator company whose technology was used in hundreds of plants around the world. It was (and still is) the Martin Company's major competitor in Europe.

The Saugus facility is often cited as being the first truly modern waste-to-energy plant. The facility brought the total U.S. waste-to-energy capacity to about 730,000 tons of trash per year, or about $0.5 \%$ of total U.S. waste generation. ${ }^{32}$ The plant was privately financed and built by the Refuse Energy Systems Company, formed by Wheelabrator-Frye, Inc., and M. DeMatteo Construction Co. DeMatteo was the owner of a local landfill that had been ordered to close because it sat inside the water table. Walter (1994-1995) describes how the alliance between the two companies was formed:

In either 1973 or 1974, a judge decided that the landfill was so bad he shut it down. On the day he did it, there were 20 or 30 towns in Massachusetts that had trucks lined up at the gate trying to get in and dump their trash. By noon, the judge changed his mind and opened it back up on condition that the owner do something else with the landfill. That led to the landowner and Wheelabrator-Frye joining forces to build the Saugus plant. That plant was the first [waste combustor] built by the private sector to produce energy.

The Saugus plant provided an important learning experience for the fledgling American waste-to-energy industry. Wheelabrator-Frye spent as much money to rehabilitate the plant soon after

\footnotetext{
${ }^{32}$ EPA estimated U.S. annual solid waste generation in 1975 at approximately 150 million tons.
} 
it opened as it did to build it, according to Harvey Alter (1995). Operating conditions turned out to be significantly different from those in Europe because American solid waste was different. Don Walter (1994-1995), then with the new ERDA, evaluated the facility to help future waste-to-energy plant operators benefit from lessons learned at Saugus:

One of the first things [ERDA] did was to look at Saugus. The plant worked fairly well, but had a few unusual problems. Not long after it started up, large, very light, greasy black particles began driving the townspeople crazy because [the particles] were coming down on their cars, the clean laundry, and so forth. At first, Wheelabrator didn't think it could be their fault. The plant's electrostatic precipitators were supposed to take care of problems like that. Well, the culprit turned out to be the oil-fired boilers General Electric (GE) had insisted they install to be sure the plant would always be able to make steam. Cages around the oil-fired burners disrupted the flow of gases through the boiler enough to make these particles. They removed the cages and sealed up the ports for the oil burners and the problem went away.

The other problem came when the grates operated for less than 15 days before they destroyed themselves. At the time, Von Roll had not built a furnace with a capacity bigger than three tons per hour and the furnaces at Saugus were designed to accept about 30 tons per hour. The increase in grate size coupled with difficulty in translating European and U.S. standards caused problems. Wheelabrator fixed the grate problem on the first try. The plant continues to operate today.

At first, the Saugus plant produced steam for a nearby GE plant across the Saugus River in Lynn. GE wanted steam for balancing and testing aircraft turbines. When the GE facility shut down, the Saugus plant began making electricity for the local grid. GE's steam purchases were an economic roller coaster both for it and for Wheelabrator, according to Walter (1994-1995):

This was the era of big price shocks for oil. By the time the plant opened up in Saugus, oil was up to $\$ 15$ a barrel and two years after that, it was $\$ 30$ a barrel. Somebody was making a killing. I suspect it was Wheelabrator, because I think their contract was based upon the price of oil when oil was \$20 a barrel. I think GE was in a continual effort to get out of that contract. No one at GE or Wheelabrator was willing to say anything other than that they were renegotiating the contract. They renegotiated that contract for 10 years until Wheelabrator installed steam turbines in their plant and started selling electricity to the grid and stopped selling steam to GE in Lynn.

As is to be expected with any new technology, other U.S. mass-burn facilities also experienced operational difficulties, including grates damaged by incomplete combustion and corrosion of waterwall and boiler tubes. The corrosion problem, which was caused by ash sticking to the tubes, was creatively solved by Wheelabrator-Frye. The company aligned its boiler tubes vertically instead of horizontally. Plant operators would then periodically drop steel balls from the top of the furnace down the tubes to knock off the ash. The balls were collected, the ash filtered out, and the process was repeated. The process was elegant, simple, and effective. 
The successful operation of Saugus and other waste combustion plants during the 1970s helped convince the new U.S. waste-to-energy industry that mass burn was a viable technology for waste combustion. ERDA assisted the new industry by helping local governments fund feasibility studies of the new technology. EPA's Levy traveled to Europe during the late 1970s to learn how cities there were able to procure complete, or turnkey, waste combustion facilities and operate them profitably. Levy (1995) used the information he gathered to assist communities in acquiring new waste combustion facilities:

I was a party to bringing the technology over here. I went to Hamburg [Germany] in 1978 and looked at their beautiful plant. I asked them how they got it. They bid it under a turnkey Request-for-Proposal, or RFP. We didn't have anything like that so we got their proposal in German and had it translated into English. We made it available to communities so they could develop their own proposals. We taught them how to develop turnkey contracts, how to procure smarter, how to market their energy, how to do cost accounting, and how to find markets for recoverable materials. Cities made a lot of use of this information.

Soon, European and American firms began offering turnkey facilities in the United States. A new era in waste combustion was born, says Levy (1995):

As U.S. cities learned how to develop specifications for new facilities and write proposals, this created a market for the Europeans. Some entered directly. A Swiss firm built a few plants, but it was difficult for them to compete against established American firms. Von Roll and Martin (which sold licenses to Wheelabrator, Allied Signal, and later Ogden Martin) emerged as more dominant because they came in with the best prices and built plants people were happy with. Because cities patterned their requests after European specifications, they asked for things that these companies knew how to build. This had a great impact. From 1981 to 1988, we built a lot of waste-to-energy plants in the United States. Most of them were built using the turnkey concept.

During the 1970s, RDF technology became a strong competitor of mass-burn technology. RDF was prepared from solid waste using various techniques to separate combustible material such as paper and plastic from metals, glass, and other noncombustible materials. Two basic types of RDF were developed: one to be burned with coal in concentrations of $10 \%$ to $20 \%$ and the other to be burned exclusively in a furnace designed for RDF. Because much noncombustible material was removed during processing, RDF facilities produced about half as much ash residue as other wasteto-energy facilities.

Union Electric's Meramec station in St. Louis, Missouri, was the first American utility to burn RDF with coal in a utility boiler. The pioneering project operated from 1970 through 1975 and led to several other large projects. The first of these came on line in 1975 in Ames, Iowa, and operated for 20 years. The Ames facility burned a mixture of $10 \%$ RDF and $90 \%$ coal. Other descendants of the Union Electric demonstration included RDF plants in Chicago, Milwaukee, Madison, and Monroe County, New York.

At the Ames plant, RDF was prepared by shredding the waste to reduce it to particles 2 to 3 inches in size before passing it through an air classifier. The light, combustible waste was removed 
and burned. Heavier materials were passed through a glass separator, an aluminum separator, and a magnet. Ferrous metals were sold, but the aluminum separator never worked very well. EPA and ERDA studied the Ames plant to better understand the technology.

During the late 1970s, RDF plants were also built in California, Ohio, Maryland, and Delaware. By the late 1980s, huge RDF plants capable of processing thousands of tons of trash per day were built in Connecticut, Hawaii, and Michigan. The latter, which are still in operation, extract up to 700 kilowatt-hours $(\mathrm{kWh})$ of electricity per ton of processed solid waste.

\section{The Waste-to-Energy Industry: 1980-1989}

PURPA set the stage for rapid growth of the waste-to-energy industry in the 1980s. PURPA required that utilities purchase electricity from small power producers, including waste-to-energy plants. By guaranteeing a market, the law made it easier for new waste-to-energy projects to obtain financing. The law was key to making many projects economically viable, according to Walter (1994-1995): "Because of PURPA, people could easily enter into contracts to sell electricity in specific areas of the country - the northeast, California, the upper Midwest, Florida - all needed electricity. We were offering reasonable rates for waste-generated electricity. Because we went into electrical production [as opposed to steam], we displaced more coal than oil."

Shortly after PURPA was enacted, DOE and EPA funded feasibility studies of waste-toenergy facilities in dozens of cities. Oscar "Ole" Ohlsson (1995) of Argonne National Laboratory recalls those efforts:

We did feasibility studies for state governments and municipalities during the Carter administration. We did 80 to 100 of them all at once for cities across the country. Most of them looked at a particular combustion system such as the Purox or Monsanto Landguard system. Some of the technologies weren't ready technically, and most of them weren't economically viable by the time we finished the studies in 1981. The RDF systems took too much equipment at a time when fossil fuel prices and tipping fees were both falling.

In 1980, 60 waste combustion plants were on line, under construction, or in planning. That same year, the Energy Security Act authorized DOE to develop a comprehensive plan for encouraging the evolving U.S. waste-to-energy industry. DOE made plans to provide loan guarantees, price-support loans, ${ }^{33}$ and technology demonstrations. At the time, Walter (1994-1995) strongly advocated price-support loans rather than loan guarantees:

Loan guarantees were a bad idea for the federal government for anything that had to do with research. In the late 1970 s, we were guaranteeing between $75 \%$ and $90 \%$ of the loans. Private parties putting up $10 \%$ to $25 \%$ of the money usually figured out that they could pay themselves high enough salaries to recoup their investment before

33 Price-support loans were based upon energy sales from a waste-to-energy plant. Starting at about $\$ 2.00$ per British Thermal Unit (Btu) the first year of operation, they fell to $\$ 0$ in the fifth year. Beginning in the sixth year of operation, plants owners had to begin paying back the loan with interest from the plant's profits. (Until then, the loan was interest-free.) In contrast to construction loan guarantees or tax credits, this arrangement encouraged developers to build plants that actually worked and to sell as much energy as possible. 
they ever got the project built. Therefore, they had no reason to really want the project to work and produce energy. In fact, that's why we came up with the pricesupport loan. That loan was set up so you didn't get paid until you produced energy. You got paid for the amount of energy you exported. And that's what we were trying to do-get energy exported.

As a matter of fact, we never got to issue a price support loan, but by 1982 we had the same result from tax law. The tax laws were changed so that whoever owned the project [a person who had invested $25 \%$ of the capital as equity] could write it off quickly. You could amortize the entire cost in five years. Plus you had an investment tax credit of $10 \%$ on the entire construction cost.

In 1981, plans for technology demonstrations evaporated when the newly elected Reagan administration rescinded the funding. DOE’s MSW program budget plummeted from $\$ 231$ million to $\$ 6.8$ million. Nevertheless, some federal monies did flow to states, municipalities, and industry for planning and technology development during the early 1980s.

The lure of federal money brought new businesses into the waste industry, increasing competition. Approximately 46 new waste-to-energy facilities were built within a few years. At the beginning of the decade, about 15 U.S. companies marketed mass-burn systems, the majority based on European technology. The misperception that landfill space near cities was declining encouraged industry growth.

The Reagan administration's strategy of privatization created a regulatory and business climate favorable to the growth of the waste-to-energy industry. Economic incentives and programs encouraged the private sector to provide services such as solid waste disposal that had until then been the province of local governments. In response, many local governments decided to issue contracts for new waste combustion facilities rather than build and operate them themselves. This tactic reduced the risks of finding an alternative for landfilling. In many communities, public officials looked at waste-to-energy conversion as the best, and sometimes the only, way to diversify solid waste disposal.

By the mid-1980s, interest in waste-to-energy was widespread. Approximately 44 states had at least one facility planned or under construction. Local governments in some states, including New York, Pennsylvania, Florida, Massachusetts, and California, began planning to replace landfilling as their primary disposal method with waste-to-energy combustion. Published, but unconfirmed reports put the nation's waste-to-energy capacity at nearly 80,000 tons per day (Blumberg and Gottlieb 1989). If this figure is accurate, waste-to-energy capacity in 1985 was already about $80 \%$ of that in 1995. At the time, most industry analysts expected this capacity to double in 5 to 7 years.

Most 1980s-vintage waste combustion facilities used mass-burn technology. In 1985, about one-fourth of U.S. municipalities had RDF waste-to-energy facilities that were operational, under construction, or in planning. About two dozen communities had plans for large RDF facilities, with a cumulative capacity of 40,000 tons per day. Most of these were never built.

The 1986 Tax Reform Act accelerated the growth of the U.S. waste-to-energy industry. The law "grandfathered" nearly 100 projects already in the planning stages or under construction, making them eligible for federal tax credits through the end of the decade. Otherwise, the tax credits would have expired in 1986. A 1987 EPA study found 110 waste-to-energy plants in operation and an additional 220 in planning or under construction. Two years later, 56 major new waste-to-energy 
facilities and 27 smaller, modular plants had opened. The smaller facilities processed less than 100 tons per day of solid waste to produce steam.

By the late 1980s, the waste-to-energy industry had begun to consolidate. Although 19 companies managed waste-to-energy plants and 36 firms were in the business of developing facilities, four companies controlled more than half the market share. The four included Ogden Martin, Wheelabrator Environmental Systems (which became Wheelabrator Technologies, Inc., a subsidiary of WMX Technologies, Inc., in 1988), American Ref-Fuel, and Combustion Engineering. Ogden Martin and Wheelabrator each had 20\% of the market share. Levy (1995) explains why the industry lost so many players despite the robustness of the market for new facilities during the 1980s:

Most of the companies weren't very large, and it takes a lot of time and money to build a waste-to-energy plant. It can take 8 to 10 years [from] the time you start negotiating with a customer [to] when you start to see any money. You need a lot of depth of organization to do all that marketing, design, and management. If you're only building one or two plants at a time, or if you have to wait a couple of years between orders, you get spread pretty thin. But Ogden Martin and Wheelabrator always had three or four going at any one time. They had some under construction. And they had money coming in so they had more staying power.

Wheelabrator Environmental Systems (created after the Signal Corporation purchased Wheelabrator-Frye, Inc.) was the oldest company marketing mass-burn technology. As Signal, the company acquired a license from the Martin Company for its grate technology and was a key vendor in the construction of the Chicago Northwest and Harrisburg plants during the early 1970s.

In 1983, Signal acquired its competitor, Wheelabrator-Frye, Inc., and created Signal Environmental Systems. Signal Environmental Systems was renamed Wheelabrator Environmental Systems when the Federal Trade Commission forced Signal to sell one of its European licenses. ${ }^{34}$ The company sold the Martin license to the Ogden Corporation and kept rights to the Von Roll technology.

During the time Wheelabrator/Signal underwent its complex corporate restructuring in the mid-1980s, the acquisition of new projects slowed temporarily. The company soon rebounded, closing a creative deal with Waste Management (a predecessor of WMX Technologies, Inc.) in 1988. Waste Management acquired nearly a quarter of Wheelabrator's stock. In return, the smaller firm received guaranteed landfill space for its combustion ash (at market price) and exclusive rights to build waste combustion plants next to Waste Management landfills. As a subsidiary of the nation's largest waste management corporation, Wheelabrator became one of two waste-to-energy industry leaders in the 1990s.

A wholly owned subsidiary of the Ogden Corporation, Ogden Martin came into existence in 1983 when its parent company purchased rights to the Martin grate technology. By 1988, the company had mass-burn plants operating in Oklahoma, Oregon, and Florida. Numerous others were under construction or in the planning stages. The company, which rapidly established itself as Wheelabrator's chief rival, continued as an industry leader in the 1990s. An Ogden Martin subsidiary, Ogden Projects, Inc., purchased three major American RDF plants from a European conglomerate in 1992.

34 Wheelabrator held the license to the Swiss Von Roll technology. 
With about $8 \%$ of the market share, American Ref-Fuel was one of Ogden Martin's and Wheelabrator's main competitors during the 1980s. The company was structured as a partnership between waste management giant Browning-Ferris and Air Products. Air Products had expertise in industrial processes, engineering, and construction. The partnership was designed to facilitate negotiations with local governments not only to build and operate waste-to-energy plants but also to provide hauling services. The firm currently operates a small number of facilities in several states.

Combustion Engineering came into the waste-to-energy field from designing conventional electric power plants, including nuclear power plants. The firm also built boiler systems for incinerators. The company focused on developing and operating RDF plants using technology adapted from the food-processing industry. During the 1980s, the company built three large RDF plants for Detroit, Honolulu, and the Connecticut Resource Recovery Authority. The Detroit plant processed 3,000 tons of solid waste per day and the other two facilities processed 2,000 tons of solid waste per day. At the time, this was approximately $7 \%$ of the market share for waste-to-energy. Asea Brown Boveri, a European conglomerate, acquired the firm in 1990 and sold its waste-to-energy plants to Ogden Projects, Inc., in 1992.

\section{The Waste-to-Energy Industry: 1990-1995}

The expansion of the waste-to-energy industry slowed during the early 1990s. Favorable tax benefits disappeared. Competition developed with landfills, forcing the industry to lower its prices even though its capital costs remained high. Industry growth was also hindered by the perception that recycling could single-handedly solve the nation's solid waste disposal problems. Public officials postponed dozens of waste-to-energy projects in favor of recycling programs.

Some environmental groups promoted the idea that waste-to-energy was competing with recycling. They questioned the impacts of air emissions and ash management on public health and the environment. At the same time, the public's trust in solid waste management declined to an alltime low. Fears fanned by repeated garbage crises spawned widespread "not-in-my-backyard," or NIMBY ${ }^{35}$, reactions. In many cities, residents opposed the siting of solid waste management facilities in their neighborhoods. The NIMBY stance took a particularly heavy toll on the waste-to-energy industry.

In spite of these and other obstacles, 37 waste-to-energy facilities were built between 1990 and 1995. The prospects for RDF technologies actually improved during this period, according to Ohlsson (1995):

$\mathrm{RDF}$ is doing better economically [because of] the escalation of tipping fees, improvements in the recovered materials markets, and a growing interest [on the part of] big coal users to reduce their $\mathrm{NO}_{\mathrm{x}}$ and $\mathrm{SO}_{\mathrm{x}}$ emissions. The Clean Air Act amendments are providing a big impetus to co-fire densified RDF with coal to reduce emissions. You're going to see a big change over the next five to six years as electric utilities consider burning RDF as an alternative to installing pollution control devices. Your local utility is going to start using alternative fuels at existing plants.

35 NIMBY reactions were so common during the 1980s and early 1990s that at least six new acronyms sprung up in response to them: NIMTOO, "not in my term of office;" NOPE, "not on planet Earth;" NOME, "Not on Mars Either;" BANANA, "Build absolutely nothing anytime near anything;" CAVE, "citizens against virtually everything;" and LEPER, "local environmental projects everybody rejects." 
In 1995, 1,300 communities in 34 states recovered energy from their waste by burning them (Taylor and Zannes 1996). Waste-to-energy facilities processed about 104,000 tons of solid waste each day and generated enough electricity to power approximately 1.2 million homes. The nation's waste-to-energy plants had a total capacity of 2.3 gigawatts of electrical power generation capacity (IWSA 1994). Mass-burn technology dominated the waste-to-energy industry, both in terms of solid waste processed and in number of facilities. Nearly 70 cities used the technology to process more than 70,000 tons of solid waste each day. RDF plants handled nearly 26,000 tons of solid waste per day-slightly more than one-fourth of the solid waste recovered for energy. Small, modular units accounted for about $3 \%$ of the total. Table 6.1 shows the number and types of waste-to-energy facilities operating in the United States in 1996.

Table 6.1. Waste Combustion Plants in the United States (1996)

\begin{tabular}{|c|c|c|c|}
\hline Technology & $\begin{array}{c}\text { No. of Operating } \\
\text { Plants }\end{array}$ & $\begin{array}{c}\text { Design Capacity } \\
\text { (tons/daily) }\end{array}$ & $\begin{array}{c}\text { Annual Capacity } \\
\left(\text { million tons }{ }^{\mathrm{a}}\right)\end{array}$ \\
\hline Incinerator & 21 & 2,881 & 0.9 \\
\hline Modular & 21 & 2,529 & 0.8 \\
\hline Mass burn & 70 & 72,813 & 22.6 \\
\hline RDF process \& combustion & 15 & 22,584 & 7.0 \\
\hline RDF processing only & 11 & 4,528 & 1.4 \\
\hline RDF combustion only & 8 & 2,995 & 0.9 \\
\hline Total U.S. plants ${ }^{\mathrm{b}}$ & 146 & 108,330 & 33.6 \\
\hline Waste combustion plants ${ }^{c}$ & 135 & 103,802 & 32.2 \\
\hline Waste-to-energy plants ${ }^{\mathrm{d}}$ & 114 & 100,921 & 31.3 \\
\hline \multicolumn{4}{|c|}{$\begin{array}{l}{ }^{a} \text { Annual totals assume that plants operate at } 85 \% \text { of design capacity. } \\
\text { b Includes incinerator, modular, mass burn, and all types of RDF plants. } \\
{ }^{c} \text { Does not include RDF processing plants. } \\
\text { d Does not include RDF processing plants or incinerators. }\end{array}$} \\
\hline
\end{tabular}

The total number of U.S. waste-combustion plants (146) included 114 waste-to-energy facilities, 11 RDF processing facilities, and 21 incinerators. The combustion facilities processed nearly 32 million tons of waste annually, or about $15 \%$ of the 207 million tons generated in the United States in 1994, according to EPA. The United States also had an additional 25 tire, cement, utility, and industrial combustion facilities, three of which recovered energy. Four other tires-toenergy plants were in the planning stage.

Table 6.2. Waste-to-Energy Combustion Rates (\% of post-recycling waste) 


\begin{tabular}{|ll|}
\hline Denmark & $80+$ \\
France & $50+$ \\
Germany & 38 \\
Japan & 75 \\
Sweden & 50 \\
Switzerland & 90 \\
United States & 21 \\
\hline
\end{tabular}

SOURCE: Skinner, John (January 1995). International Solid Waste Association.

In the mid-1990s, most waste-to-energy capacity was located in Florida, New England, and the Mid-Atlantic states. These densely populated areas have high rates of municipal waste generation and relatively little land suitable for landfilling. In such areas, energy recovery from solid waste is an essential part of integrated waste management. In 1996, there were five new waste-to-energy plants under construction with a total design capacity of 2,645 tons per day (Taylor and Zannes 1996). There were seven facilities with a total capacity of 10,523 tons per day in advanced planning stages. Waste combustion plays a much greater role in solid waste management in other industrial countries than it does in the United States, as shown in Table 6.2.

\section{The Federal Program}

The federal government has played a significant role in developing and improving waste-toenergy techniques. The government's efforts, which began when the nation faced the 1973 energy crisis, resulted in research and development programs for promising new technologies. According to EPA's Levy (1995), people thought scientists could solve any problem, including the energy crisis, by developing new technologies:

There was a big push in the early 1970 s to develop new technologies, to come up with a better mouse trap. We wanted new solutions. We didn't want to take an incinerator and figure out how to make it better. We wanted to come up with something different so we wouldn't need incinerators.

We were a nation of rocket scientists, a nation that saw itself using its technological might to solve problems. After we put a man on the moon in 1969, that project ended, and we had a lot of technical talent available for other projects. We had companies like Boeing, Union Carbide, Occidental Petroleum, Caterpillar, General Electric, Westinghouse, McDonnell-Douglas, and Monsanto coming up with environmental technologies and working on solutions to solid waste problems.

The Bureau of Solid Waste Management, EPA, ERDA, and DOE supported numerous projects between 1968 and 1998, including waste combustion, biological processing, and landfill gas recovery, which is discussed in the next chapter. The Bureau of Solid Waste Management began funding research and demonstrations in 1968 for the development of innovative waste-to-energy technologies, including:

- The Monsanto Landgard rotary kiln gasification system 
- The Purox oxygen-blown shaft furnace gasification system

- The Andco-Torrox hot-air cupola furnace gasification system

- The co-firing of RDF with pulverized coal.

Harvey Alter (1987) describes these projects in detail. The Bureau continued to support them after it became a part of EPA in 1971.

ERDA, DOE, Argonne National Laboratory, and NREL conducted applied research to develop better fuels derived from MSW for more than 20 years. Walter (1994-1995) describes the philosophy he brought to the ERDA and DOE MSW research programs:

Even in the beginning, our philosophy was that the most important thing was that new technology get used. The second most important thing was that it get used economically. Somewhere in all this, we were always the energy people. We pushed toward the energy side believing that you don't want to harm the environment- just use technology economically and get the energy back from the waste.

If all things were equal, if you produced a kilowatt-hour from municipal solid waste and you got the same pollution as if you produced a kilowatt-hour with coal, you broke even. So what was the difference for the environment? That's why we always looked at what was going on from a life-cycle perspective. Here is where the energy is produced, here is where it is delivered, here is where it is used, here is where it is reused, here is where it ends.

In the mid-1970s, ERDA evaluated a unique waste-to-energy plant built in Nashville, Tennessee. Walter (1994-1995) remembers this facility was built to work like a Navy destroyer:

It was designed to burn coal, but used municipal waste instead. It was operated like a destroyer with one boiler running at 140\% capacity and the other on standby. When you get into deep trouble, a destroyer has to move as fast as it can. The idea seemed like a good one for municipal solid waste. However, operating one boiler at $140 \%$ capacity led to severe maintenance and repair problems.

The coal design didn't take account of the characteristics of municipal solid waste as a fuel. We did some work to try and determine what the problems were and how they might be solved. In the end, the plant operated both boilers at design capacity and solved many of its problems. The plant is interesting because it produces hot and chilled water for a distinct heating and cooling loop.

In 1976, ERDA began working with the National Bureau of Standards (now the National Institute of Standards and Technology) to define the amount of energy in MSW. Walter (1994-1995) recalls how the project originated:

The project grew out of discussions with WEPCO, a firm preparing to buy RDF from a large Waste Management facility in Milwaukee. The RDF was to be burned in two boilers. Both companies needed a simple way to measure the energy content of the $\mathrm{RDF}$. Technology at that time could reduce a pile of waste as big as a room to a 
representative one-gram sample: A pellet one inch in diameter and one-half inch thick made from hundreds of cubic yards of waste. We were trying to see if we could come up with a device that could test a 5-pound sample. Industry wanted this and the Bureau of Standards had expertise in doing devices this size. We financed a project to build a 5-pound sample calorimeter, which the Bureau successfully completed.

ERDA investigated factors that influenced markets for waste-to-energy conversion. Early on, the agency noticed most waste-to-energy plants experienced a negative cash flow during the first 3 to 5 years of operation. Then, during the next 15 years, cities often made profits on their waste-toenergy plants. At that point, cities either reduced their tipping fees or lowered the price of energy sold to local facilities. Such economic realities led the MSW program to devise an innovative strategy for encouraging cities to build new waste combustion plants. Walter (1994-1995) describes the concept of price-support loans envisioned by the program:

We dreamed up the price-support loan so we could lend a city enough money to make their negative cash flow zero-out during the first five years of plant operation. Then we would get the money back by sharing the profits. Our estimate was that it would take three to five more years for us to get our money back. Then we could set up a sort of revolving fund [for other cities to use]. We actually got it in place. As a result of the Energy Security Act [of 1980], we had \$215 million to do the first deal.

Then Reagan got elected, and all those things were suspended. We went back to being a more pure research organization. The idea of going from basic research right on through to demonstration and commercialization disappeared.

Federal support for waste-to-energy technology development dropped significantly during the early 1980s. Even so, DOE's MSW program was able to help industry continue development of several promising technologies. In the meantime, the private sector continued to build mass-burn facilities with waterwall furnaces originally developed in Europe. Since federal officials believed mass-burn technology was already mature, they did not support technology development programs.

Federally sponsored research focused on four waste-to-energy technologies: modular combustion, anaerobic digestion, pyrolysis, and RDFs. All four were considered potential competitors for mass-burn technology. Small, modular combustion units installed in apartment houses, commercial buildings, or industrial sites were the most widely used of the four. Originally designed to reduce the volume of solid waste, the units became small waste-to-energy plants with the addition of heat-recovery units for producing hot water, steam, or hot air. Federal officials believed the technology to be mature and supported little research on it. Anaerobic digestion, which did receive substantial research support, is discussed in the next section on biological processing. 


\section{Pyrolysis Research}

Pyrolysis, a process for converting solid waste into gaseous and liquid fuels, consists of heating waste with little or no oxygen present. The lack of oxygen prevents the waste from catching fire. Depending upon temperature and other conditions, the waste will decompose into relatively low-energy gas, a heavy oil-like liquid similar to fuel oil, or a solid char with a heating value similar to coal. If the goal is to maximize the production of fuel gas rather than liquid fuel, the process usually is called gasification rather than pyrolysis. Because gaseous and liquid fuels are easier to transport, store, and use than mixed waste, researchers believed they would offer many advantages over mass-burn technology. Thus ERDA supported pyrolysis research, according to Walter (1994-1995): "We did some work on gasification of municipal solid waste as a way [of recovering] energy from MSW. Municipal waste is solid and you can't put it in a boiler designed for oil or gas. You could only put it in a suspension-fired coal boiler if you put a grate in the bottom of the boiler. So we began to do some work on gasifying waste so [it could be put] in any kind of boiler. It's still a dream."

From 1977 until early 1980s, ERDA and DOE supported industry experiments of innovative pyrolysis technologies. During the late 1970s, nearly two dozen pilot projects were built. However, the goal of producing liquid fuels using pyrolysis proved elusive. Most processes produced a gunky residue filled with carcinogens and other poisonous compounds. Nearly all experienced serious problems with air emissions. The poor experience with pyrolysis created some skepticism regarding the reliability of waste-to-energy combustion.

Most pyrolysis plants built during the 1970s were pilot or demonstration projects developed very quickly in response to the energy crisis. In some cases, large plants were built before engineers understood basic processes well enough to scale them up successfully. Many proved to be expensive and unreliable compared to mass-burn technology.

The largest pyrolysis plant was built in Baltimore, Maryland. Using the Monsanto Landgard system, the facility was designed to convert 1,000 tons per day of trash into a low Btu gas inside a kiln heated to $1,800^{\circ} \mathrm{F}$. The plant burned the gas to make steam, which was sold to the Baltimore Gas and Electric Company. Ferrous metals were recovered and sold from process residue, which consisted of an iron and glass aggregate. The facility experienced serious operational difficulties after it began operations in 1975, according to Levy (1995):

Monsanto built the plant for [EPA] in Baltimore using kiln technologies it had developed for other uses. The company thought solid waste problems would be comparatively simple to solve. So they built the plant [and] then ran into problems. The problem was that solid waste is... heterogeneous and variable. It might be $99 \%$ paper, glass, metal, and plastic, but in that last $1 \%$ is everything anyone has ever made - battery acid, sticks of dynamite, whatever gets thrown away. These things may show up only once in a while, but when they're there, they cause extremes of explosiveness, acidity, and flammability. A cement kiln can be designed for a narrow band of characteristics and handle the same thing day after day, but a solid waste plant [cannot].

The federal MSW programs gained invaluable knowledge and experience with pyrolysis. Based on this experience, researchers concluded that gasifiers should be superior to waste combustion, both in terms of efficiency and environmental impacts. Unfortunately, development of 
this technology has ceased in the United States. With the exception of wood gasifier projects in Hawaii and Vermont, the development of this promising technology is taking place in Europe.

\section{RDF Technology Development}

More than half a dozen different kinds of fuels from solid waste have been developed since the 1960s. Since 1973, these fuels have been known as RDFs. Initially, unprocessed solid waste burned directly in mass-burn waste combustors was considered to be a form of RDF. However, the term RDF now denotes solid waste that has undergone at least some processing to remove noncombustibles before being burned for energy.

Under the auspices of the 1965 Solid Waste Disposal Act, the Bureau of Solid Waste Management sponsored a series of studies of fuels derived from solid waste. The Bureau was instrumental in launching RDF research at the U.S. Bureau of Mines (Alter 1987). At first, the Bureau of Mines worked on developing methods for recovering metals and glass from incinerator ash. It later expanded its efforts to create systems for recovering paper and plastic and developed several types of RDF in the process.

NCRR was one of the first groups to work on densified refuse-derived fuel, or d-RDF. Private industry, EPA, and ERDA were also active in efforts to make d-RDF from municipal waste. Levy (1995) describes the evolution of RDF:

When we started developing RDF, the idea was for it to be a supplemental fuel to be burned with coal, e.g., $80 \%$ coal and $20 \%$ RDF. We thought it would be straight forward since power-plant technology was already there. But we found there were technical problems, and utilities were reluctant to take the fuel. The companies going the RDF route decided to develop a dedicated RDF boiler. It had a different feed system, a different grate, and its geometry was different because you burned more material in suspension. Several American equipment manufacturers, including Combustion Engineering, Babcock and Wilcox, Detroit Stoker, and American RefFuel, developed subsidiaries or spin-off companies to build turnkey plants of this type.

EPA funded an NCRR project to produce a fuel that could be stored, transported, and mixed with coal for use in a coal-fired power plant. NCRR did research on making fluff and d-RDF from shredded waste and operated a 200 ton-per-day pilot plant in Washington, D.C.

Another project to demonstrate the use of d-RDF with coal in the nation's capital was less successful. NREL's Carlton Wiles (1995-1997) recalls that a project to demonstrate the technology for Congress never got off the ground:

EPA headquarters wanted to do a bicentennial MSW project in 1976. So we started planning about mid-1974. The idea was that we would burn d-RDF in the Capitol building in Washington, D.C. I met with [Speaker of the House] Tip O'Neill's staff to work out the details. The National Center for Resource Recovery was going to make the pelletized fuel. Finally, we met with the boiler operator himself, and he said, "No way am I going to chance having an outage and having a congressman call down here and ask: 'Where the hell is my heat?"' And that was the end of it. The moral of the story is: Get your boiler operator on board early. 
In the late 1970s, DOE's Argonne National Laboratory began to conduct research on RDF. Through the years, the laboratory faced many challenges. Wiles (1995-1997) describes some of them: "Processing MSW into d-RDF turned out to be no easy task. Processing rates through the pelletizing mills were very slow. There were corrosion problems. But even after you produced some good pellets, they would deteriorate when stored. They would swell when exposed to moisture and could become biologically active. DOE picked up the work and overcame some of the problems." Argonne's comprehensive research project compiled information on operating facilities, plant design, environmental controls, and recycling markets. It also developed new methods for RDF production and combustion. The laboratory pioneered an advanced RDF pelletization method that used special chemical binders. The method solved three key problems: (1) RDF deterioration during storage, (2) the need for separate feed systems for coal and RDF, and (3) poor combustion associated with older pellets and RDF fluff.

The laboratory recently completed comprehensive combustion and emissions tests of cyclone furnaces fueled by a mixture of coal and enhanced RDF pellets. Cyclone furnaces operate more efficiently at higher temperatures than conventional furnaces, producing the hotter steam temperatures favored by utilities. The tests showed that co-firing RDF and coal in a cyclone furnace met EPA's 1991 environmental standards for waste-to-energy emissions including dioxin.

\section{Economic and Political Issues}

Since the 1980s, economic and political issues have had a greater impact on the waste-toenergy industry than have technical issues. Commercial technologies are well established. However, the costs of building new facilities (due in part to the cost of complying with stringent air emissions regulations) have continued to rise. In the meantime, the costs for landfilling (the industry's main competition) have decreased. Many solid waste experts believe that public acceptance of solid waste combustion has been uneven because of opposition to the technology from environmental groups.

Costs

High capital costs have been an issue for communities wishing to build new waste-to-energy facilities. For example, construction costs for Baltimore's waste-to-energy facility built in 1985 totaled $\$ 180$ million. In addition to construction costs, there were interest payments on construction loans, insurance costs, permitting fees, and so forth. Creative financing still made this a good investment, according to Walter (1994-1995):

At Baltimore, Wheelabrator put up a quarter of the $\$ 180$ million cost of building the plant (\$45 million). The city sold $\$ 225$ million worth of bonds to cover construction costs. Wheelabrator got an $\$ 18$ million tax credit the first year, and then amortized [the remaining \$27 million] in five years. I once figured out that the return on their investment was about $40 \%$ in five years, which was pretty good.

Not surprisingly, you had a tremendous spurt of construction of waste-to-energy plants. Some [company] like Wheelabrator would build one and immediately sell their piece of it to some [company] like General Electric Acceptance Corporation, Ford Acceptance Corporation, or GM Acceptance Corporation. The [companies] did this primarily to keep the entire cost of the plant off their books. Build five of these, and suddenly [there's] a billion dollars of debt on [the] books, which might make it hard to get another loan. So companies stripped their loans off to other [firms] so 
they could do more. The [firms] who were buying ... were very interested in ... the tax credit because they had fairly large profits and they were looking to shelter their profits. Even though the tax law (with the renewable energy tax credits) went away in 1986, there were still many facilities being built because the tax advantages were secured and you could still finance new plants with industrial development bonds.

This was good public policy for several reasons: It drove ownership [and plant operation] of most waste-to-energy plants into the private sector where they were operated as businesses for profit. Waste-to-energy plants were not city services where the mayor could give his brother-in-law a cushy job and hire lots of people who would vote for him in the next election. Waste-to-energy plants made profits, and those profits were shared with the city. Because [the plants] were privately owned, taxes flowed into state and local treasuries. As a matter of fact, there are studies showing that the tax return was equal to the tax loss. The real problem was that the tax loss came from the federal treasury and the tax return came locally.

Today, a new large facility easily costs over \$200 million. Financial incentives like Walter describes are no longer available. Since the late 1980s, the cost of building a new waste-to-energy facility has increased, even as landfilling costs have begun to decline. Levy (1995) explains:

[Waste-to-energy] is a big capital investment. In the mid 1980s, waste-to-energy and landfilling were fairly close together, but [then] they diverged in cost. The average waste-to-energy tipping fee used to be $\$ 56$, but [it grew to] twice that price [in 1995]. The increase in cost was driven by regulation and cost inflation. Every generation of plants (meaning every year or two) was more complicated and more sophisticated. [Plants have] more controls. New plants now have continuous air emissions monitoring. Waste-to-energy was not nearly as competitive in 1994 as it was in 1988.

Since 1995 waste-to-energy plants have lowered their fees to be more competitive. The action came in response to the demise of traditional flow controls, which had guaranteed waste deliveries to these facilities, regardless of tipping costs.

Effective solid waste planning and engineering studies can go a long way toward keeping waste-to-energy costs under control. It is crucial to design a new facility for the amount of solid waste it will actually receive, which means accounting for the impact of recycling and other solid waste management methods during facility planning. A plant designed to process 1,000 tons of solid waste per day will not operate economically with 400 tons per day. Finding other solid waste may not be the most cost-effective solution either, because transportation costs run between $\$ 0.50$ and $\$ 1.00$ per ton per mile.

\section{Siting}

Siting new waste-to-energy facilities can take 5 years or longer and is not possible without public support. The process typically involves selecting a site, obtaining a permit, and arranging for financing. Once a facility is approved, it can take 2 to 3 years to build the plant. 
Public opposition is the primary reason siting takes so long. Residents are often concerned about safety, reliability, and property values. If homeowner equity is a major asset of residents, opposition to a waste disposal facility is often high. Nevertheless, such issues typically disappear after a waste-to-energy facility begins operation (Walter 1994-1995).

Lack of public education regarding the need for the facility and indecision on the part of officials can also fuel opposition to a project. Education coupled with a willingness on the part of officials to negotiate throughout the process with the public are key ingredients in successful siting. It is crucial that officials address the concerns of residents early in the process of deciding to build a new facility. Public participation is essential not only in selecting the final site but also in locating and evaluating sites. The siting process should rely upon scientific assessments and judgments rendered by trusted officials.

Once a facility comes on-line, cities should make every effort to mitigate risks posed by the facility with frequent inspections and rigorous enforcement. Otherwise, residents may perceive they bear an unfair burden of health and environmental risks compared to nearby communities.

\section{Compatibility with Recycling}

When recycling became popular during the late 1980s, its proponents opposed waste-toenergy plants. They believed the two methods competed for the same solid waste and thus were not compatible. Recent studies have reconfirmed that the real competition to waste-to-energy is landfilling, not recycling (Kiser 1992).

Communities using MSW combustion had an average recycling rate of $25 \%$ in $1994-\mathrm{a} 12 \%$ increase over the previous year. Waste combustion made significant contributions to the relatively high recycling rate. Seventy-one waste-to-energy facilities and three incinerators recovered a total of about 738,000 tons of ferrous metals for recycling. Depending on plant design, metals were recovered either before or after combustion.

Apparent conflicts between waste-to-energy conversion and recycling tended to focus on paper and plastics. Both can be recycled or burned. Similarly, yard waste can be composted or burned. According to Walter (1994-1995), using solid waste as a fuel offers economic and environmental advantages:

I want solid waste to be used as a fuel. People who argue against using it for fuel have no concept that $20 \mathrm{MW}$ of electricity from municipal waste means $20 \mathrm{MW}$ is not produced in a coal-fired plant, and we've just made the air better. Everybody talks about the pollution that comes out of the stack of a waste-to-energy plant, but they never talk about what doesn't come out of some other stack. As it turns out, waste-to-energy produces less pollution on average than other forms of generation [from coal and oil, for instance].

Burned paper produces about $\$ 50$ worth of energy per ton, so you really ought to get more money than that for your paper if you're going to recycle it. Compost leaves and garden waste if you have a market. If you don't, throw them in a waste-to-energy plant. Leaves can be pretty dry by the time you pick them up. Besides, waste-toenergy plant operators don't care very much in November and early December whether yard waste is wet or dry. That's when municipal waste is tailing off anyway. 


\section{Technical Issues}

Emissions control and ash disposal (or recycling) are technical issues that continue to elicit interest from waste management professionals, environmental groups, and the public. Although political concerns often give rise to these issues, specific problems are frequently addressed with technical solutions.

\section{Emissions Control}

Since 1970, the waste-to-energy industry has complied with EPA standards for pollutants emitted by waste combustion facilities. The pollutants include nitrogen oxides, ozone, particulate matter, carbon monoxide, lead, and sulfur oxides. From its infancy, the waste-to-energy industry had to install the best available technologies to control emissions of these substances. As a result, wasteto-energy electrical generation produces less pollution than fossil-fuel generation, according to Walter (1994-1995): "The modern municipal waste plant is cleaner than the modern coal plant because EPA regulations say it will be. So from an environmental standpoint, we are better off with a waste-to-energy plant. Building a waste-to-energy plant actually reduces the pollution level."

During the 1980s, EPA identified other substances in waste-to-energy emissions that posed real or imagined health risks. These substances included mercury, cadmium, zinc, arsenic, and such organic chemicals as polychlorinated bi-phenyls, vinyl chloride, dioxins, and furans. Since 1991, the waste-to-energy industry has also had to control emissions of these materials. There are 75 different dioxins and 135 furans, which are often collectively referred to as dioxins. Even in very small amounts, some of these substances are thought to be toxic or carcinogenic. Dioxins were implicated in the contamination of Love Canal in New York and Times Beach in Missouri. They were also produced in the manufacture of Agent Orange, a defoliant used during the Vietnam War. The public has long considered Agent Orange to be responsible for a rash of health problems plaguing Vietnam veterans. In the public's mind, dioxins are a much feared hazardous waste.

In 1977, dioxin was identified in the emissions of a New York incinerator. Subsequent tests revealed that waste combustors and incinerators emit small, but varying amounts of dioxin. So do forest fires, paper mills, and coal-fired power plants. Several theories have been propounded regarding the source of the dioxin emissions, but this issue has yet to be resolved scientifically. The threat posed by emissions of trace amounts of dioxin has been the subject of much debate since the early 1980s - notwithstanding a notable lack of objective scientific data. During the late 1980s, environmental groups publicized real and imagined public health issues posed by emissions of dioxins and heavy metals as a means of slowing the growth of waste-to-energy and encouraging recycling.

Public pressure led EPA to set stringent dioxin emission standards for waste-to-energy facilities in 1991 and even more restrictive ones in 1995. These regulations occurred despite evidence that waste combustors produced only about $3 \%$ of the dioxins known to be present in the air. EPA also regulated emissions of mercury and other heavy metals in 1991 and 1995. Lanny Hickman (1995-1997) of SWANA gives the most recent regulations a lukewarm endorsement. "We're not opposed to regulating emissions, but we are concerned about the lack of scientific basis for the current regulations. I don't view the rules as overwhelmingly bad, but I don't think the incinerators in this country are getting a fair shake. There are other combustion sources out there that represent far greater sources for certain pollutants." Nonetheless, waste-to-energy firms invested in costly new technologies to meet the stringent federal emissions standards set in 1991 and 1995. 
The waste-to-energy industry has included pollution controls in its solid waste combustion plants since the 1970s. Federal legislation and regulation were the driving forces behind the requirement to install state-of-the-art emissions control technologies. Ironically, the heating plant on Capitol Hill was not brought into compliance with air pollution regulations for an inordinately long time, according to Walter (1995-1997): "The heating plant on Capitol Hill was probably the last plant in the United States to [be fitted with] electrostatic precipitators. Congress continually refused to vote the funds and put pollution controls on the plant that heated [its] buildings. Meanwhile, [it was] telling everybody else [to use] pollution control equipment."

The two most common air pollution control systems used in facilities built before 1995 were (1) a combination acid-gas scrubber and fabric filter (baghouse) and (2) an electrostatic precipitator. Scrubber systems controlled emissions of sulfur dioxide and acid gases. "Wet" scrubbers effectively removed sulfur dioxide, but created wastewater requiring treatment. For this reason, "dry" scrubbers were chosen more often for pollution control after about 1987. Fabric filters used in combination with scrubber systems effectively removed the majority of particulates from waste gases. Since dioxins and heavy metals often adhere to particulates, the filters also helped remove these pollutants as well. The combination of dry scrubbers with fabric filters received a designation of best available control technology by EPA in the late 1980s.

A 1995 survey of waste-to-energy plants (Kiser 1995) revealed that the scrubber-fabric filter combination was used at $42 \%$ of waste-to-energy plants and electrostatic precipitators were used in $34 \%$ of the facilities. Some type of lime injection was used at $22 \%$ of the plants. About $13 \%$ of waste-to-energy facilities had controls for nitrogen oxide and $6 \%$ had controls for mercury. In addition to pollution controls, nearly three-fourths of waste-to-energy plants operating in 1995 had continuous emissions monitoring equipment. About $16 \%$ of the plants were linked via computer to a regulatory enforcement agency, which allowed 24-hour continuous emissions monitoring.

Most waste-to-energy projects in planning or under construction have been designed to use a scrubber-filter combination in conjunction with nitrogen oxide and mercury controls. About onethird are to use some type of lime injection. All new facilities are to continuously monitor emissions and nearly two-thirds of them will transmit emissions data to a regulatory agency. The adoption of more stringent emissions monitoring and sophisticated emission controls at new facilities came in response to the new air-emission standards promulgated by EPA in November 1995.

From 1992 to 1996, NREL supported research projects on controlling emissions from municipal waste combustion. SWANA, the Institute of Gas Technology, ASME, and private companies conducted the studies. Research topics ranged from evaluations of the causes of dioxin emissions to assessments of new methods for reducing acid-gas emissions.

In 1993, NREL sponsored two important studies on dioxin and mercury emissions. The dioxin study showed that the removal of PVC plastics from MSW does not necessarily lower the amount of dioxins formed during waste combustion. For this reason, operators of MSW combustors will need to control dioxin emissions to meet regulatory standards whether or not MSW contains PVC plastics. The mercury-emissions study estimated that mercury emissions from MSW combustion in 2000 would be $95 \%$ lower than they were in 1989. According to the study, several factors will contribute to the projected decrease in mercury emissions, which are expected to fall from 97 tons a year to 4 tons a year. These factors include the use of better technology for controlling mercury emissions, a reduction in the amount of mercury used in fluorescent lamps, and the diversion of some types of mercury-containing batteries from MSW. The report concluded that MSW combustors would be a relatively minor contributor to the nation's mercury emissions after 1995. 
Three research projects completed in 1994 examined new technologies for controlling acidgas emissions from MSW combustors. In one project, the Institute of Gas Technology, in cooperation with private industry, completed the design of a new emissions reduction testing system. The system uses natural gas and specially designed chemical processing to reduce emissions of acid gases, carbon monoxide, dioxins, heavy metals and other pollutants. If the new system is further developed and commercialized, it could significantly lower the costs of emissions control for MSW combustion.

Massachusetts Refusetech, Inc., looked at the effect on acid-gas emissions by adding lime to the combustion furnace or sodium bicarbonate (baking soda) to the ducts carrying hot gases away from the furnace. The lime injection system significantly reduced one of the three major acid gases (sulfur dioxide) present in the smoke. However, the sodium bicarbonate system had little additional impact on emissions.

NREL and EPA worked together in 1994 to identify key technologies for reducing emissions of nitrogen oxides, an acid gas that also catalyzes the formation of ozone, an irritating, chemically reactive component of urban smog. The joint study evaluated processes for reducing nitrogen oxides and concluded that a combination of two new technologies could reduce nitride oxide emissions by up to $85 \%$. The study also identified research and development needed to refine the technologies and lower their costs.

In 1996, NREL, in conjunction with the ASME and EPA, completed an evaluation of an innovative method for retrofitting older MSW waste combustors to control acid-gas emissions. The method uses a temperature-controlled chemical injection process to remove acid gases from exhaust gases. Older facilities typically use electrostatic precipitators, which can only remove ash and other particulates from exhaust gases. These facilities must now add acid-gas control systems to comply with EPA's 1995 emissions guidelines. The ASME study showed that the new method is far less costly than retrofitting the facilities with standard acid-gas control technology consisting of spray dryers and fabric filters. The study concluded that small facilities (processing less than 250 tons per day) should be able to use the new method to meet new emissions guidelines.

Ash

Waste combustors produce two types of ash: ash trapped by air pollution control equipment and bottom ash. Air pollution control residues consist of the particulates entrained in hot exhaust gases (fly ash), other pollutants trapped by emissions-control technologies, and residues from scrubbing agents such as lime. Generally speaking, air pollution control residue, which comprises no more than $20 \%$ of the total ash produced, has more toxic materials than bottom ash. Bottom ash forms on the grates inside the furnace and drops into water in the bottom of the furnace. Water cools the ash, but leaves plant operators with the messy problem of drying out the ash (dewatering). Several plants experimented with dry bottom boilers, but removed them because of difficulties in controlling dust in the plant. Bottom and fly ash can be disposed of separately, but most facilities combine them prior to disposal in an MSW landfill.

Since the 1980s, environmental groups have raised concerns regarding the burial of MSW combustion ash in landfills. They argued that the acidic environment inside a MSW landfill could carry heavy metals such as lead, nickel, cadmium, chromium, mercury, and arsenic out of the ash, contaminating groundwater. When MSW ash failed the original toxicity tests designed by EPA, several groups urged EPA to classify combustor ash as a hazardous waste, which would require prohibitively expensive disposal methods. 
When EPA declined to do so, the dispute was taken all the way to the Supreme Court ( $C B E$ v. City of Chicago). The Court determined in May 1994 that MSW combustion ash was not exempt from federal hazardous waste regulations. Thus, waste-to-energy plant operators had to determine whether their ash was hazardous. One method to do this is to use the toxicity testing prescribed by EPA. However, modern EPA toxicity tests have consistently demonstrated combustor ash to be nontoxic. Alter (1995) believes the lawsuit should never have happened: "I call this the incinerator ash debacle. The Supreme Court had to settle a case between Chicago and the Environmental Defense Fund that was based on 1980s practices that were already out of date. The lawsuit never should have happened, but politics got in the way." Industry experts fear that the lawsuit may have slowed progress on ash recycling. John Merritt (1995), former director of the Solid Waste Division of Environmental Futures, Inc., explains: "Ash is pretty benign, pretty valuable stuff under certain circumstances. Disposal is expensive. Recycling includes simple, low-tech use of bottom ash or combined ash in aggregates and roadbeds. It's inexcusable that ash recycling has been basically stalled."

There are several emerging technologies for recycling combustion ash. Ash can be used to make roadbeds, bridge abutments, asphalt filler, and as a substitute for natural aggregates such as sand and gravel. The key to making a good ash aggregate is removing unburned combustibles from ashes before recycling. Five states (Florida, Maryland, Minnesota, New Jersey, and New York) have pilot programs to recycle ash from waste-to-energy plants. The applications under study include roadbeds, building materials, and artificial reefs. Using a high-tech, but relatively expensive, processing method known as vitrification, ash can be recycled into insulation materials. The vitrification process was evaluated by the ASME, EPA, and the U.S. Bureau of Mines (before it was closed). The process uses an electric arc furnace to harden and stabilize ash and other waste. It has been tested successfully with waste combustion ash, fly ash from an RDF plant, and sewage sludge.

In 1995, DOE supported several research projects on ash utilitization, which showed that there are no adverse environmental or health impacts from using waste-combustion ash in pavement. At the time, the ash studies were expected to contribute to research on a comprehensive, integrated waste management strategy in which materials and energy were fully recovered from municipal solid waste. Because even combustion ash could be recycled, this strategy would have significantly reduced the need for landfilling. However, the planned evaluation of the strategy was canceled when the DOE MSW program ended.

In Europe, ash is widely used. For example, bottom ash from waste-to-energy plants in and around Paris is recycled as road base during highway construction. Firms in Denmark, the Netherlands, Germany, and Japan use combustion ash in various construction projects, such as roads, parking lots, and bicycle paths. Across the Atlantic, Bermuda uses stabilized ash blocks to reclaim land and provide shore protection.

\section{Waste Combustion Methods}

Currently, mass-burn, modular-combustion, and RDF technologies are the only waste combustion methods currently used commercially in the United States. Mass-burn systems are simpler and, consequently, less expensive than RDF technologies, which prepare the MSW to improve its quality as fuel. Mass-burn systems burn MSW virtually straight off the collection trucks inside huge furnaces. Facilities of this type use waterwall or modular boiler systems. Over the years, the federal government has sponsored little research into mass-burn technologies and methods. One exception is a small project sponsored by DOE in the 1990s to develop a method for burning sewage sludge in a waste-to-energy facility. 


\section{Waterwall Furnaces}

Waterwall furnaces are commonly used in mass-burn waste combustion plants. The furnaces are lined with water-filled tubes to capture the radiant heat of combustion. The waterwall design is more efficient than the fire box and boiler system used in older incineration plants. A waste-toenergy facility equipped with a waterwall furnace operates as follows: Mixed MSW is deposited in a large pit or receiving area, known as the tipping floor. (In British English, the word tipping is a synonym for dumping.) Cranes move the waste from the tipping floor to the incinerator intake. When possible, crane operators remove large, noncombustible items such as appliances before adding the solid waste to the hopper that feeds the boiler.

Once inside the furnace, solid waste is burned on a moving grate system. In one design, the grates are angled toward the intake chute. Long bars on the grate raise up into the waste and pull it down onto the grate. In another design, the grates operate like individual fingers that push up into the waste and move it down the grate. Burning refuse ignites the incoming solid waste, while air is forced through the grates to control combustion. The furnace is designed to maintain a temperature of $1,800^{\circ} \mathrm{F}$. The heat turns water inside tubes that line the furnace into steam. The steam is recovered and used for district heating and industrial processing or is converted via steam turbines into electricity.

Technological improvements have gradually improved the operating efficiency of waterwall combustion plants. Twenty years ago, the most efficient plants produced $500 \mathrm{kWh}$ of electricity per ton of waste burned. Today's facilities can produce up to $700 \mathrm{kWh}$ per ton of waste burned.

\section{Modular Combustion Units}

Small, modular solid waste combustion units may be used in apartment houses, commercial buildings, and industrial sites. Originally designed to reduce the volume of waste, the units became small waste-to-energy plants with the addition of a heat-recovery unit for producing hot water, steam, or hot air. Modular systems, which are usually prefabricated, contain one or more small combustion units and process 50 to 100 tons of solid waste per day.

\section{RDF Production}

RDF consists of pelletized or fluff solid waste produced in an RDF production facility or as a by-product of resource recovery. Production methods are designed to separate noncombustible materials from paper, plastics, food, textiles, and so forth.

RDF processing facilities use a series of techniques that can be combined in various ways. The techniques include shredding the waste to reduce particle size, separating metals and glass from mixed waste with magnets or by hand, separating waste by size by passing it through screens or rotating drums known as trommels, and air classification. In magnetic separation, strong magnets remove steel cans and other ferrous metals from the waste. Laborers usually pick aluminum cans and glass off conveyor belts.

Screens and trommels separate waste particles according to size as does an air classifier. Strong air currents inside an air classifier separate light, combustible paper and plastic waste from heavier cans and glass. If these materials have not been previously removed, the heavier fraction passes through magnets and other separators to recover glass, aluminum, and steel. The light fraction, or RDF, can be burned directly as fuel or formed into pellets. RDF can also be compressed into a briquette-like form. Binders are often used to maintain the integrity of pellets and briquettes. 
In another method for making RDF, waste is wet pulped to form a slurry. Magnets remove metals from the slurry. Screens and centrifuges remove other noncombustible material. Water is removed from the remaining waste, which is pressed into cakes. The cakes can be used as boiler fuel.

Although some RDF facilities ship their products to users such as utilities at other locations, nearly two-thirds of the RDF plants burn their products on site. RDF is burned mostly in dedicated boilers rather than co-fired with coal in utility boilers.

\section{RDF Combustion}

RDF can be burned with coal in utility or industrial boilers. In early designs, a fuel mixture consisting of $5 \%$ to $20 \%$ fluff RDF fuel was mixed with coal and burned in a suspension-fired steam generator. In some plants, the RDF burners were situated above the main coal burners to ensure that the RDF was burned in the hottest part of the furnace. Design capacities for RDF co-firing plants ranged from 200 to 2,000 tons per day.

The nation's three largest RDF plants use traveling grate, spreader-stoker boilers specifically designed for uniformly sized, pelletized RDF. In this system, RDF fuel burns both in suspension and on a moving grate inside the furnace. To ensure complete combustion, air is swept into the furnace above the fuel to keep it well mixed. This technology solves some of the problems with incomplete waste combustion associated with co-firing RDF in suspension boilers. Plants using this technology range in design capacity from 400 to 3,000 tons of solid waste per day.

\section{Biological Processing}

In addition to combustion, there are biological methods of recovering energy from solid waste. Using microorganisms to ferment waste into alcohol fuel, a gasoline substitute, or to make energy-rich biogas may be promising technologies. Biogas, which is $50 \%$ to $60 \%$ methane (the main ingredient in natural gas), can be used to produce heat or electricity.

\section{Anaerobic Digestion}

Human beings have long known that waste rotting out of contact with air will produce a flammable gas. In Tibet and China, for example, villagers have for centuries maintained dung pits that produce gas used for heating and lighting. The biological process responsible for producing the gas in dung pits is similar to that which occurs in landfills, marshes, and other areas where waste decomposes in the absence of oxygen. When microbes cause waste to decompose under these conditions, the process is called anaerobic digestion. Anaerobic digestion, which can be a very efficient process under controlled conditions inside an air-tight vessel, occurs in a haphazard and unpredictable fashion in marshes or landfills. Anaerobic digestors produce two to four times as much methane in a few weeks as many landfills produce in a decade or more.

The recent history of controlled anaerobic digestion goes back to an early treatment for wastewater, in which solid matter was removed by letting it settle out in septic tanks. Inside the septic tanks, foul-smelling sludge was digested by anaerobic bacteria, which also produced methane gas. The gas from one such septic tank was used for street lighting in England as early as 1895. Although the method successfully reduced the organic content of wastewater, the digestor tanks were often covered with scum and emitted a putrescent odor. These problems were solved with a new double tank designed by Karl Imhoff in the early 1900s. In the Imhoff design, two tanks were stacked one on top of the other. Solids dropped through slots in the bottom of the upper sedimentation tank into a sludge compartment. Microorganisms digested the sludge, producing biogas. Material left from this process was dried and discarded or used as fertilizer. The first U.S. Imhoff-design tanks 
were used in New Jersey around 1911. By the 1930s, half of U.S. wastewater treatment plants used Imhoff's tank design.

The success of using anaerobic digestion to treat sewage sludge inspired researchers to evaluate the technique for solid waste disposal. The U.S. Public Health Service began studying anaerobic digestion of solid waste in 1969. Researchers wanted to learn how to convert as much solid waste as possible to biogas. At first, the project's goal was to reduce the volume of solid waste rather than to use the biogas for energy.

In the early 1970s, the city of Franklin, Ohio, built a facility for pulping solid waste with the goal of using the pulp to make roofing felt. When this did not work, engineers put the pulp into an anaerobic digestor where it produced methane despite difficulties in mixing the dried fiber. The experiment to make roofing felt inadvertently became a precursor to federally supported projects to develop anaerobic digestion.

In the wake of the 1973 energy crisis, researchers began exploring ways to productively use the biogas produced during anaerobic digestion. In 1975, ERDA began a project with Pacific Northwest Laboratory to enhance energy recovery from sewage sludge. Walter(1994-1995) explains why ERDA was interested in the project:

We knew that there were a lot of anaerobic digestors in sewage plants, but we also knew that very few of them used the gas that they produced. As many as $90 \%$ of them flared the gas, so we started looking at ways to encourage them to use the gas for energy. That meant we had to answer questions like: How do you make more gas more uniformly?

Sewage plants ran their digestors to stabilize sludge, not to produce gas. We were trying to look at them and see how to get them to switch their goal from sludge stabilization to the production of gas. Because the gas was $50 \%$ to $60 \%$ methane, you had to scrub out the carbon dioxide in it and add a little bit of mercaptan, and then you'd have substitute natural gas.

Those were exciting times. In 1975, we also worked on combustion of sludge. We looked for ways to dry sludge mechanically so you could get enough water out of it to burn it and get some energy back.

The National Science Foundation's Research Applied to National Needs (RANN) program began investigating anaerobic digestion in 1973. Initially, the program looked at the digestion of solid waste, manure, and wood. It began funding a waste management project to build and operate an anaerobic digestor at its Pompano Beach, Florida, landfill. The digestor was designed to process 50 to 100 tons of solid waste per day. In 1976, ERDA took over the RANN project, passing it along to DOE in 1978. DOE operated the Pompano Beach digestor between 1977 and 1987. The experience allowed researchers to better understand the process of anaerobic digestion and to define engineering requirements for a commercial-scale demonstration project. Walter (1994-1995) explained his goals for the project:

The basic idea was to build an anaerobic digestor at a sewage treatment plant, then add MSW to sewage sludge. We'd get enough methane to run both plants and have some left over. The project was very successful and we learned lots. I have lots of 
confidence that if we could build a full-scale plant, it would do what it was supposed to do. The biggest problem we had was with the sludge. We concluded it was easier to dewater it and burn it even though that was an issue for some environmentalists.

Don Walter requested funds for a full-scale commercial demonstration of this technology for more than 10 years after the project ended, but it was never funded.

After 1985, DOE supported additional studies of anaerobic digestion. As part of this effort, NREL developed a high-solids digestor for methane production. The digestor used microbes that occur naturally in waste to transform garbage into a methane-rich biogas and compost. In developing the new digestor, NREL researchers created a technology that combined techniques for sewage treatment with backyard comporting.

The high-solids digestor used less water and processed as much solid waste in a day as ordinary reactors 20 times its size. Consequently, it produced more biogas at a lower cost than conventional digestors. The new technology's economic prospects appeared bright, according to Wiles (1995-1997):

Anaerobic digestion has the potential to occupy a wider niche than people think. We have had requests for information about the process from seafood interests in Alaska, California, the Virgin Islands, Puerto Rico, and other areas. The method appears promising where there is a high concentration of organic waste, such as fish or food processing waste, sewage sludge, animal waste, or agricultural waste, in addition to MSW. It's ideal for a community that cannot afford a big waste-to-energy plant. Unfortunately, we don't have the budget to work with people who are asking for help or who want a demonstration project.

The digestor worked best when trash was mixed with oily food waste such as tuna sludge. This feature is a key selling point. Fat, oil, and grease wastes, which are common in the food industry, are difficult to dispose of. A pilot plant using the new technology was planned for testing in California in 1998. It will process RDF mixed with tuna sludge from a local cannery.

Experience gained from operating the pilot plant will permit engineers to design commercial systems for islands and other communities that must manage both organic waste and MSW. On the island of Tediously in American Samoa, for example, there are two large tuna canneries. Together, they produce about 200,000 gallons of tuna sludge per day. The island also has marginal landfill capacity to manage its residents' garbage. NREL's high-solids digestor offers a good solution for both these waste problems. The digestor could provide the island with biogas to fuel electrical power generation and compost to enhance its impoverished volcanic soil. The compost could also provide cover for the local landfill.

\section{Alcohol Fuels}

Like alcoholic beverages, alcohol fuels can be produced by fermenting plant materials with yeast or other microorganisms. The microscopic creatures live off carbohydrates like starch and cellulose in bamboos, producing alcohol as a by-product.

Military scientists studied the fermentation process at the Army Quartermaster Laboratories in Gnathic, Massachusetts, after World War II. The project was initiated to understand why the clothing of U.S. soldiers rotted so quickly in the South Pacific. The cause turned out to be an alcohol-producing bacterium that fed on cotton. The discovery of a new microorganism meant that 
researchers could develop methods for making alcohol fuels from bamboos, including solid waste. Like cotton, solid waste contains a lot of cellulose. Cellulose is a major constituent of wastepaper, some textiles, yard waste, and even some foods. Animals and most microbes, including yeast, cannot digest cellulose, however. Therefore, traditional methods for making alcoholic beverages from starch do not work with cellulose.

The federal government initiated a research and development program to make alcohol fuels from solid waste in response to the 1973 energy crisis. The program's goal was to develop renewable transportation fuels from solid waste and energy crops. (Energy crops are fast-growing trees and grasses grown specifically for energy use.)

NREL and TVA conducted research on alcohol fuels from MSW for more than 15 years. Using techniques from microbiology and genetic engineering, NREL developed a method for converting the cellulose in wastepaper, yard trimmings, and agricultural waste into alcohol fuel. TVA developed a chemical method for converting the cellulose in wood or solid waste into sugars, which yeasts could then ferment into alcohol.

The process of making alcohol fuel from solid waste begins the same way with either method. MSW is collected and delivered to a materials recovery facility. Glass, metals, plastics, and other materials unsuitable for ethanol production are removed. As soon as cellulose-rich materials are relatively free of contaminants, they undergo a mechanical milling process to reduce their size and make fermentation work better. Up to this point, the process is similar to making RDF.

In the TVA method, pelletized RDF is fed into a fermentation vat via a conveyor belt. Magnets placed over the conveyor remove any remaining metal fragments from the RDF. Inside the fermentation vat, the RDF is treated with a dilute acid to break down cellulose into simple sugars. Yeasts convert the sugars into alcohol. The reaction vessel contains gypsum to remove any metals that may have dissolved in the acidic reaction mixture. The alcohol is recovered by fermentation, and waste solids are used as boiler fuel to make process steam and electricity. The low-cost method produces ethanol for less than $\$ 1.00$ per gallon. TVA researchers believe the method could be economical in plants processing at least 2,000 tons per day of MSW.

NREL's method uses both chemicals and enzymes to break down cellulose into sugars, which are fermented into alcohol by yeast and bacteria present in the reaction mixture. After fermentation, the "beer" containing the alcohol is removed for distillation to pure ethanol. The enzymes, bacteria, and yeast are recovered and recycled back through the fermentation system. Residue is removed and used as a boiler fuel to provide energy for alcohol production.

The future of this promising technology is unclear. Funding for MSW research has disappeared, and research must rely on other funding sources. The process for converting bamboos into alcohol is not yet ready for commercialization. In 1996, both chemical and biological methods for recovering energy from solid waste still cost significantly more than simply landfilling the waste. And, with no money for MSW research on the horizon, it is not clear what will bring down costs for waste-to-energy conversion in the future.

\section{Profile: Carlton Wiles}

Carlton Wiles spent the early part of his career as a researcher at the U.S. Department of Agriculture. Following a stint in biological warfare research at Fort Detrick, Maryland, Wiles become project director in 1970 for the U.S. Public Health Service/TVA's experimental compost 
project in Johnson City, Tennessee. When the project ended a year later, Wiles was transferred to the U.S. Public Health Service's research facility in Cincinnati, Ohio, which was being transferred to EPA at the time.

Wiles was one of approximately 100 researchers assigned to EPA's MSW program in Cincinnati when the agency was formed. Wiles led an MSW processing group that designed and built a pilot plant to recover waste materials, operated a small incinerator, conducted research on anaerobic digestion, and investigated the conversion of wastepaper to alcohol fuel. Major budget cuts in the mid-1970s forced the group to suspend its in-house research and support contract research exclusively. By 1981, Wiles' group had shifted its attention to hazardous waste research in support of impending federal hazardous waste regulations.

Wiles returned to directing MSW research projects in the late 1980s. Key projects included the evaluation of waste management technologies, landfilling technologies, and the treatment and use of incinerator ash. Wiles left EPA in 1993 to become manager of the Municipal Solid Waste Program at NREL. 


\subsection{Landfills}

From the perspective of history, the idea that modern landfills should now be deemed to be a major social problem ... is rather ironic. ${ }^{36}$

Dumping on land is the world's oldest method for getting rid of solid waste. In its modern form, known as landfilling, it is the most widely used solid waste management method in the United States. It is also the lowest cost way to manage MSW, at least in the short run.

Most communities have land suitable for landfilling within a reasonable distance. Some states, Florida for example, and regions like the Northeast where suitable land is scarce rely less on landfilling than other regions. Even so, these regions still use the method for disposing of combustion ash and MSW that cannot be managed in any other way.

Despite its popularity, landfilling solid waste remains problematic. Environmental groups, regulatory agencies, and the public continue to express concerns regarding the long-term environmental impacts of putting solid waste in landfills. Some forward-looking solid waste management professionals also worry about the loss of material and energy resources.

\section{History of Landfills}

The history of landfilling in America consists of numerous efforts by government and industry to ensure that landfilling solid waste protects human health and the environment. As practiced in the United States until the 1970s, landfilling was unacceptable. It resulted in air and water pollution and encouraged flies, rats, and other vermin. In 1972, more than 14,000 municipalities had open dumps. Many allowed the burning of waste in landfills, whether it occurred by accident or deliberately. Don Walter (1994-1995), explains: "We used to just throw municipal waste into open dumps. Every so often, somebody would throw in a match so it all burned off. This was even worse than putting garbage into an incinerator." To make matters worse, there were more unauthorized dumps than legal ones. Despite obvious drawbacks to this disposal method, it took the nation a long time to find an alternative.

It took even longer to figure out that sanitary landfilling could also threaten environmental quality. The nation's first sanitary landfills were opened in the 1930s, but people did not realize until the mid-1970s that poorly designed sanitary landfills could cause air and water pollution. Then it took another 15 years before federal regulations were put in place to remedy the problems. Improved landfilling methods were not consistently implemented in new facilities until after 1990.

Sanitary landfilling was developed during the 1920s by the British, who called it "controlled tipping." At first, the method consisted of covering newly deposited solid waste with a layer of soil each day. Daily cover was a significant improvement over open dumping, because it helped reduce wind-blown litter; made it easier to use bulldozers to compact waste; reduced odors; and discouraged flies, birds, rodents and other vermin.

In the 1930s, New York City and Fresno, California, built the first American sanitary landfills. The U.S. Public Health Service endorsed sanitary landfilling in 1940 for its ability to protect the public health by controlling rats and mosquitos. Unfortunately, Americans were unaware

Perennial, p. 84. 
that sanitary landfills could also contaminate groundwater and destroy wetlands. The conventional wisdom was that landfills could be sited anywhere, including in ravines, swamps, and abandoned sand and gravel pits.

The U.S. Army Corps of Engineers experimented with sanitary landfilling during World War II and evaluated the method's ability to protect the health of soldiers stationed at American bases during the war. The army's success with landfilling encouraged several cities to adopt the technique after the war. Harvey Alter (1995) explains why sanitary landfilling was welcomed with open arms: "The Army Corps of Engineers developed sanitary landfills because suddenly the army had training camps. The draft started in 1940. After the war, sanitary landfills were viewed as a great thing. Cities started to shut down open dumps. Before that, it was the open dump for hundreds of years. You torched it, and it burned. It stunk. Fire helped keep the rats away." Sanitary landfilling was affordable, and it avoided most of the objectionable features of open dumping such as squalor, foul odors, rats, vermin, and open burning. Sanitary landfills appeared to be a good alternative to incineration, too. Landfills not only accepted solid waste but also took in sewage sludge; industrial, construction, and commercial wastes; lawn trimmings; and even chemical waste.

Many of the nation's first sanitary landfills were small and relatively shallow. ${ }^{37}$ Frequently, little effort was made to compact waste. Because aerobic waste decomposition predominated, landfills produced mostly carbon dioxide and very little methane. There was little, if any, monitoring of gas production or movement of the liquid, known as leachate, produced during decomposition. Even if there had been, the technology for tracking these materials may not have been sufficiently sensitive and reliable to detect problems. Officials saw little need to evaluate landfill sites for reuse because they were considered worthless.

\section{Groundwater Pollution}

For many years, public health officials had little understanding of either the causes of or remedies for pollution associated with landfilling. A 1954 study of the landfill in Riverside, California, concluded that sanitary landfilling would not pollute underground aquifers as long as the landfill itself was not in contact with groundwater. This conclusion became the basis for U.S. landfill design for nearly 20 years. Unfortunately, it was valid only for southern California and other semiarid regions with relatively impermeable soils.

During the 1960s, public works officials continued to believe sanitary landfilling protected land and water from pollution - even when evidence of contamination began to surface. A 1961 report from the American Society of Civil Engineers enthusiastically endorsed the method. The report also discussed and dismissed a minority opinion that groundwater pollution was occurring in $20 \%$ to $50 \%$ of sanitary landfills. With benefit of hindsight, it is clear that even this estimate was low.

By the early 1970s, environmental publications were openly critical of sanitary landfilling. They argued that landfills not only contaminated groundwater but also produced noxious fumes and explosive concentrations of methane gas. Curiously, a 1971 EPA report entitled Sanitary Landfill Facts continued to endorse the long-standing idea that pollution from sanitary landfills was rare (U.S. EPA 1971). The report did, however, recommend siting landfills well away from streams, lakes, wells, and other water supplies.

37 California's canyon landfills were a notable exception. 
Researchers finally began field studies of landfills in the 1970s. Within a few years, public officials realized that groundwater was far more vulnerable to landfill pollution than they had been taught. By 1975, it had become impossible to site a landfill in a swamp or other wetland area-the very areas once considered ideal for landfilling. The nation's prolonged ignorance of the consequences of solid waste disposal on land was finally over. However, recriminations and fingerpointing would continue for another decade. In the meantime, public opposition to landfills grew strident. New landfills had to be sited in distant locations, giving rise to increased transportation costs for waste.

Decades of groundwater pollution caused by sanitary landfilling grew out of a serious misconception. Public officials believed that the ground beneath the earth's surface had a nearly limitless capacity to absorb and filter even the most toxic chemicals. This myth was dispelled by advances in chemistry in the mid-1970s. Sensitive new tests showed unequivocally that many of the nation's aquifers were contaminated with toxic and carcinogenic chemical compounds. These were the same compounds that were ubiquitous in the leachate formed inside a sanitary landfill.

Leachate is created when water percolates through waste, extracting chemicals and germs from industrial waste and sewage sludge buried along with solid waste. Many chemicals present in leachate can move freely into groundwater systems and persist there for years. Leachate passes freely through permeable soils recommended for landfilling prior to 1970.

\section{Problems with Landfill Gas}

Beginning in the late 1960s, there were sporadic references to gas generation within and around landfill sites. Despite such warnings, landfills continued to be sited in quarries, pits, and other structures that facilitated the movement of leachate and gas from the landfill into surrounding areas. As time went on, it became clear that landfill gas could cause problems when it migrated out of the fill area. It smelled bad, posed health risks, and increased the danger of fire or explosion. Until the late 1980s, practices for controlling landfill gas migration were lax. EPA documented 40 instances in which gas migration out of a landfill caused an explosion or fire (Thorneloe 1992). Ten incidents caused injury or death.

Pockets of methane did not usually present an explosion hazard inside a landfill because oxygen was not present. The danger of explosion came from gas that migrated outside a landfill and collected in a basement or other structure. One of the most dramatic landfill gas explosions occurred in September 1969 at the National Guard Armory in Winston-Salem, North Carolina, which had been built about 20 feet from an old, uncontrolled landfill. The blast injured 25 guardsmen, 12 seriously. Three men died and seven were permanently disabled. Methane was responsible for the explosion. When mixed with $5 \%$ to $15 \%$ by volume of air, methane is explosive. With more air, the colorless, odorless gas becomes a fire hazard. The generation of landfill gas, poor management techniques, and the high temperatures sometimes associated with anaerobic digestion may even have been responsible for a few of the "spontaneous" fires associated with open dumps. However, because open dumps typically produced very little methane, most fires had other (mostly manmade) causes.

Landfill gas rises to the surface of the landfill where it escapes into the air. Even with modern techniques to control landfill gas emissions, all landfills emit some gas to the atmosphere. Landfill gas also spreads out horizontally. Unless a landfill has some kind of side barrier (now required by EPA regulation), the lower gas pressures at the edges of landfills foster the diffusion of methane out of the landfill into adjacent soils or buildings. Diffusion of landfill gas is enhanced if highly permeable soils are present around the landfill. Landfill gas can also migrate away from the facility 
via wastewater conduits. Researchers have shown that methane can travel through soils up to 1 kilometer away from a landfill.

In a few instances, landfill gas caused deaths by asphyxiation when it migrated out of a landfill, filled culverts and sewers, and displaced air. It also dislodged air in soil around plant roots, damaging crops or foliage. The methane itself was not toxic to plants, but it displaced oxygen needed by soil microbes. High concentrations of carbon dioxide also injured roots.

Landfill gas often has a putrid odor, particularly during the early stages of biological processing. Trace gases, including hydrogen sulfide, organic sulfur compounds, and some organic acids are responsible for the foul odors. In the past, these odors annoyed nearby residents and often led to opposition to landfill siting.

\section{Problems with Landfill Settlement}

In the mid-1960s, the practice of building residential or commercial structures on top of old landfills came into question. In New York in 1966, for example, row houses built just seven years earlier had to be demolished when an unstable landfill beneath the houses caused floors to tilt and walls to crack. Within a few years, landfill gas explosions in Richmond, Virginia, and Commerce City, Colorado, created additional concerns regarding the wisdom of building housing developments over old landfills.

\section{Changes in Landfilling Practices}

Change came slowly in response to the improved understanding of the problems associated with sanitary landfilling. For most of the decade, there were no federal landfilling guidelines for states wanting to improve practices. The landfilling guidelines issued by EPA in 1979 were relatively modest. They effectively put an end to open dumping but had almost no effect on sanitary landfilling methods. Landfilling methods were eventually improved as a result of the more comprehensive regulations promulgated in 1991.

The nation's first controlled sanitary landfills were built during the early 1970s. Even by the mid-1980s, about $40 \%$ of MSW still went into nonpermitted facilities, however. Nonpermitted facilities often failed to meet the minimum criteria for a sanitary landfill. Decisions made during the 1970s to close polluting municipal incinerators had kept up the pressure on landfills to dispose of greater amounts of solid waste - regardless of the consequences to the environment.

Improved landfill technologies and methods were more widely used by the end of the 1980s. In 1991, EPA codified them into a stringent set of federal criteria for land disposal under Subtitle $\mathrm{D}$ of the RCRA. The criteria set minimum standards for landfilling that states were required to implement. When EPA issued the new regulations, officials feared they would precipitate another garbage crisis as communities were forced to close poorly operated landfills. Instead, the new regulations benefitted the solid waste management industry, according to EPA's Steve Levy (1995):

EPA said a landfill [had] to have cover, leachate control, and gas control. When we came out with this [set of regulations], we expected it would create a tremendous landfill crisis. There were 6,000 landfills around the country, and communities had them for years and years. They just kept making them higher and higher. They weren't very well designed in the first place. Now, all of a sudden, communities were under pressure to close their landfills to keep from having to incur financial obligations. 
The new federal criteria created a tremendous business opportunity. Browning-Ferris, Waste Management, Laidlaw - all the big waste management companies — started big regional landfills that could handle 4,000 to 5,000 tons of solid waste a day.

The waste management industry built [many] large landfills - all competing for the waste. They're using rail haul, long-distance truck haul. They designed the new landfills to meet the new standards. They all have double liners, leachate collection systems, and gas controls. These large, well-engineered facilities are run as big businesses. They have economy of scale. It's all pure cash flow, with fixed costs. They can take 2,000 tons a day for the same cost as they can handle 1,000 tons, but they get twice as much revenue from tip fees.

\section{Landfilling in the 1990s}

In the 1990s, landfills are sited away from aquifers, rivers, lakes, and oceans. They are lined with dense clay and, in some cases, a flexible membrane (plastic) liner. They are designed so moisture cannot flow into or out of the landfill. They are operated to minimize the formation of leachate. They collect and treat leachate as wastewater. Groundwater near the landfill is monitored for contamination. Methane gas is collected and flared (burned) or used for energy. Landfill operators cover new waste each day with soil or another approved cover to eliminate odors and control vermin. After closure, the landfill is sealed with a clay cap or flexible-membrane liner. Closed landfills are typically developed for other uses such as a park or golf course.

In the United States, there are about 300 large public and private landfills, which accept from 750 tons per day to more than 4,000 tons per day of solid waste. These facilities handle more than 110 million tons of solid waste per year, or more than half the total U.S. waste generation, according to EPA estimates. Newer, regional landfills offer the full package of environmental protection and often charge less than their polluting predecessors. There are also more than 2,500 older, smaller landfills still in operation. The smaller facilities manage another 20 million tons of solid waste a year. Levy (1995) says that the large U.S. landfill capacity translates into lower solid waste disposal costs for communities:

A landfill used to charge a community $\$ 35$ a ton because the community had no other choice. Now that same city has a big, competitive regional landfill it could use, so one or both landfills drop the price to $\$ 28$ a ton. In 1993, the average tip fee paid at landfills actually declined - probably for the first time in history - from $\$ 29$ a ton in 1992 to $\$ 28$ a ton in 1993. Before that, costs had been going up steadily. In the mid 1980 s, it cost $\$ 8$ or $\$ 9$ a ton to landfill waste. Now you have private landfill operators chasing each other for the waste. So the prices are going to stay flat or come down. This is making it difficult for cities to invest in a new waste combustor, because they cost so much money to build and they're not as competitive.

Despite lower landfilling prices, the solid waste management industry continues to invest in new and larger landfills because they are profitable. The industry appears to be planning to stay in business over the long haul, too, according to Levy (1995):

After landfill operators cover their costs, it's all gravy after that. If they double the amount of waste they get, they practically double their profits. It's not like they make 
$3 \%$ on each truckload. They've built the infrastructure for the long haul. They've bought semi- and tractor trailers. A big percentage of waste is moved by rail. And it's not that expensive. When you're talking $\$ 50$ to $\$ 60$ a ton to burn it, you can haul waste a long way for $\$ 50$ a ton. You can damn near mail it for that price.

\section{Waste Processing inside Landfills}

Once solid waste is deposited in a landfill, it undergoes two types of changes: compaction and degradation. Compaction occurs when heavy equipment rolls over the waste, crushing it and squeezing out air. When compaction equipment works as intended, it can increase the density of waste inside a landfill by a factor of two. Even with compaction, waste continues to settle under the weight of new waste deposited on top of it. Landfills typically settle between $15 \%$ and $25 \%$, depending on the quality of the compaction.

Since at least the early 1940s, scientists have understood that buried refuse decomposes in the absence of air to produce methane. Because landfill contents remain undisturbed, waste degradation is a kind of hit or miss affair, taking place in some locations, but not in others. Degradation takes place very slowly, particularly in newer landfills designed to keep moisture out. Food and garden waste decompose inside a landfill, but often very slowly. Paper and textiles break down even more slowly. Certain kinds of organic materials such as plastic or rubber rarely decompose inside a landfill. Because landfills are not ideal environments for decomposing waste, only one-fourth to one-half of the waste buried in a landfill actually decomposes.

\section{The Formation of Landfill Gas}

During the late 1970s, researchers at Georgia Tech under the direction of Dr. Fred Pohland identified five distinct, but overlapping phases of landfill stabilization: aerobic degradation, transition, acid formation, methane production, and stabilization. Each phase involved the biological processing of waste by specific microorganisms, which produce characteristic waste degradation products. The formation of landfill gas occurs during the process of landfill stabilization.

Microorganisms begin to slowly decompose food, paper, and other organic materials even before they are deposited in a landfill. Aerobic bacteria (which require oxygen to live) break down the waste, and produce carbon dioxide and water. In the first phase of landfill stabilization, aerobic degradation continues inside newly deposited waste near the surface of the landfill. In most facilities, only about the top three feet of compacted waste have enough oxygen to support aerobic decomposition.

The next phase or transition, begins when oxygen supplies dwindle inside the buried waste. New kinds of bacteria begin to appear under low-oxygen conditions. Eventually, anaerobic bacteria, which grow in the absence of oxygen, predominate.

In the third phase, anaerobic bacteria break down waste, producing carbon dioxide, hydrogen, and an acidic leachate rich in such organic acids as acetic acid. (In dilute form, acetic acid is the primary constituent of vinegar.) Very little methane is formed during the acid-formation phase, which lasts months or even years.

During the fourth phase, methane production occurs. New types of anaerobic microorganisms convert acetic acid and other degradation products into methane and carbon dioxide. As methane generation becomes steady and consistent, landfill gas production rates soar. 
The initiation of steady methane production is a critical step in landfill stabilization. If it does not occur, a "sour" landfill may result. ${ }^{38}$ The methane formation stage may last for many years before methane production gradually decreases.

Acid formation and methane production are key phases in the generation of landfill gas. Landfill operators sometimes recirculate leachate through buried waste to accelerate the biological activity occurring during these two phases. Leachate recirculation speeds up landfill stabilization and enhances landfill gas production.

Eventually, a landfill reaches stability, and biological activity declines. This is the fifth, or final stabilization phase. During the time it takes for the landfill to reach maturity, different parts of the landfill may be undergoing different phases of waste decomposition. Aerobic and anaerobic processing may not always be distinct within the buried waste.

Methane and carbon dioxide are produced in equal amounts inside a landfill. However, because some carbon dioxide dissolves in the leachate, landfill gas is normally composed of about $55 \%$ methane and $45 \%$ carbon dioxide. Landfill gas contains more than 100 different trace gases. The gases include vinyl chloride, benzene, toluene, hydrogen sulfide (and other sulfur compounds), chlorinated hydrocarbons, and volatile organic compounds. The composition of these trace gases varies from landfill to landfill. They are produced during biological processing and by chemical reactions that occur naturally inside the landfill. Both the composition of waste and landfill operations affect the formation of these trace gases.

The rate of generation of landfill gas depends on the composition of the waste inside the landfill, the ease with which the waste undergoes biological processing, moisture, and temperature. Because moisture helps bring waste and nutrients into contact with microorganisms, it is a key factor in rapid biological processing of waste. Temperature is also important because it affects the type of bacteria that thrive inside solid waste. Depending on waste composition, 1 ton of solid waste may produce anywhere from 50 to about 200 cubic meters of landfill gas. Landfill gas collection systems recover from $30 \%$ to $85 \%$ of the gases generated. The remaining gas is eventually emitted to the atmosphere. The variation in landfill gas production and collection makes it essential that landfill operators monitor gas production at each facility. Solid waste rich in food and yard waste produce much more landfill gas than waste with a high content of paper and cardboard.

\section{The Formation of Leachate}

Leachate is a complex wastewater containing high concentrations of organic and inorganic chemicals. As water flows down through a landfill, it dissolves a variety of compounds. Some of these compounds come into the landfill with the original waste. Others, such as organic acids, are produced during biological processing. By the time the water reaches the bottom of the landfill, it must be treated and managed as wastewater. Examples of the chemicals found in leachate include:

- Compounds of barium, calcium, magnesium, sodium, potassium, iron, and manganese

- Ammonia, chlorides, sulfates, borates, sulphides, arsenates, selenates, and carbonates

\footnotetext{
${ }^{38}$ In a "sour" landfill, a buildup of organic acids eventually halts microbial activity. The acidic leachate leaches contaminants from the buried waste and poses a particular threat to groundwater if it escapes from the landfill.
} 
- Traces of heavy metals such as mercury, cadmium, zinc, lead, copper, nickel, and cobalt ${ }^{39}$

- Motor oil

- Strong acids

- Toxic organic chemicals, including ketones, phenols, volatile fatty acids, and other aromatic and chlorinated hydrocarbons.

The formation of leachate depends upon the amount of water inside the landfill. Some moisture comes from the solid waste itself. While the landfill is still open, water also comes in from rainstorms, snow melt, flooding, and runoff. If a closed landfill has not been designed to keep liquids out, liquid continues to enter the facility and groundwater may percolate through the waste. Generally speaking, more leachate is produced at the end of winter and during spring, when weather conditions may result in heavy snows, rapidly melting snow, or rain. During summer, leachate formation is reduced by evapo-transpiration.

The formation of leachate is reduced by covers and other structures that keep rainwater from flowing into the facility. Waste compaction also reduces the amount of leachate. Leachate cannot be entirely eliminated from a landfill, however, because water cannot be completely excluded from the solid waste mass.

A landfill must incorporate a leachate drainage system. The leachate can be recycled through the landfill, treated at the landfill, or treated at a wastewater treatment facility. Treated leachate can be discharged to a sewer, river, lake, or land irrigation system.

Leachate recirculation can enhance biological processing inside a landfill. Buffers, nutrients, and methanogenic bacteria may be added to the leachate before it is recycled through the landfill. The additions encourage the growth of anaerobic bacteria, speed waste decomposition, enhance methane production, and help the landfill to reach stability sooner. Leachate management is a critical part of landfill design. A landfill that leaks can pollute groundwater for more than 100 years.

\section{Landfill Research}

Since 1970, EPA, DOE, and Argonne National Laboratory have conducted some (limited) landfill studies, which explored the distribution of gases inside landfills, landfill emissions, and the processing of organic waste inside a landfill. During the 1970s, for example, researchers performed experiments at the landfill in Mountain View, California, to determine ways to enhance airless biological processing. They discovered that too little moisture inside the landfill inhibited bacterial growth by preventing access to important nutrients. The studies also showed that methane production was enhanced by treating recirculated leachate to keep it from getting too acidic.

\section{Energy Recovery from Landfill Gas}

The MSW programs at ERDA and DOE sponsored landfill gas recovery research for nearly 20 years. The long-term availability of federal funding, in conjunction with the provisions of PURPA, helped create a landfill gas industry during the 1970s and 1980s.

\footnotetext{
${ }^{39}$ The amount of mercury in leachate is normally very low because under the conditions found inside a landfill, mercury and other heavy metals form chemical compounds that cannot dissolve in water.
} 
Rolling Hills Estates in California was the site of the first commercial landfill gas-to-energy project, which began operation in 1975. During the mid-1970s, ERDA and EPA worked with California utilities and private industry on gas recovery from the Palo Alto and Mountain View landfills. As Walter (1994-1995) recalls:

The first one [ERDA] worked on was built in Palo Alto. A company called NRG put in some pressure-swing absorption systems to clean up the landfill gas to make a substitute natural gas. They sold the gas to Southern California Gas for injection into their pipeline. At the same time, we began work in conjunction with EPA and Pacific Gas \& Electric at the Mountain View landfill. We cooperated with the landfill owners to put in a system to understand gas generation, recovery, clean-up, and all sorts of issues.

In 1977, ERDA sponsored the first of a series of annual meetings of experts in landfill gas recovery at Johns Hopkins' Applied Energy Research Laboratory. The meetings sowed the seeds for yearly international solid waste meetings, currently sponsored by SWANA. Walter (1994-1995) recounts how the meetings evolved: "When Lanny Hickman retired from EPA, he went to work for the Government Refuse Collection Disposal Association. In 1981, we hired [him] to begin running the landfill gas meetings for us. Two years later, it was so successful that we could just back out. The meetings continue today without government support."

During the late 1970s, DOE sponsored research and demonstration projects on using landfill gas as a boiler fuel and to generate electricity. The projects proved the technologies were feasible. In a series of studies, EPA, DOE, Argonne, and NREL discovered that the biggest technical challenge in recovering energy from landfill gas was in cleaning the gas, removing water from it, and enriching the methane fraction. During the 1980s, DOE sponsored research on gas cleanup technologies at NREL. Although new understanding was gained of the challenges involved, the development of affordable, efficient methods remained elusive.

More recently, research efforts focused on using fuel cells to recover energy from landfill gas. Fuel cells convert methane directly to electricity. DOE is currently working with the Electric Power Research Institute (EPRI) on a molten carbonate fuel cell that may significantly improve the efficiency of landfill gas recovery. EPRI has estimated that 700 U.S. landfills could use the technology to produce 6,000 MW of electricity (Friedrich 1995). The implementation of this promising technology awaits the development of an affordable, effective gas clean-up system.

Another technology under evaluation is the production of liquid fuels from landfill gas. A pilot plant to produce diesel fuel from waste began operation in Pueblo, Colorado, in 1992, and failed shortly thereafter. A second pilot plant, which produces methanol, began operation at the BKK landfill near Los Angeles in 1993.

\section{EPA's Landfill Methane Outreach Program}

EPA's Landfill Methane Outreach Program was created in response to President Bill Clinton's 1994 Climate Change Action Plan. The EPA program seeks to increase energy recovery from landfills by working with landfill operators, states, native American tribes, utilities, and other federal agencies. EPA would like to help medium- and large-sized landfills economically operate energy recovery systems. Landfill emissions regulations, which took effect in March 1996, now require some of these landfills to control their gas emissions. 
The EPA program is targeting information, regulatory, and other barriers that keep otherwise economic projects from going forward. It promotes regulatory flexibility, provides technical information, helps publicize opportunities for new projects, and educates landfill owners and operators regarding the benefits of using landfill gas to produce energy.

EPA's outreach program planned to work in cooperation with DOE's MSW program, which conducts research and development to overcome technical barriers to energy recovery. However, DOE was not able to work with EPA as planned because of 1996 budget cuts.

\section{Current Issues in Landfilling}

The nation's continued reliance upon landfilling for solid waste disposal has raised a number of technical and political issues, including the need for more landfill research, landfill mining and reuse, siting, emissions, and stewardship of landfills in the future.

\section{Research}

EPA's landfill criteria were designed to prevent the pollution of nearby land and water. But researchers need to learn much more about what happens inside a landfill before newer, more advanced designs can be developed. It is not even clear whether the basic design, which keeps liquid inside the landfill to a minimum, is the best solution to the pollution problem. Landfill design is dictated by regulation, not scientific consensus, according to Robert Landreth (1995), formerly with EPA's research laboratory in Cincinnati, Ohio:

We have lots to learn about landfilling. There are no landfill design manuals yet. We're nowhere near getting one, either. There are no landfill operations manuals. We don't even know whether current cover designs will be adequate in all locations. EPA's original intent was to create a national landfilling program that would work anywhere, from Arizona to the East Coast. Unfortunately, there are big differences between these two places. We need to recognize those differences and attack landfilling problems in site-specific ways.

Until they reach stability, landfills release methane to the atmosphere, contributing to greenhouse warming. To make matters worse, the wastepaper, food waste, yard trimmings, and textiles in a landfill constitute energy that could have been recovered. Detailed studies of landfill gas emissions and methods for efficiently recovering material and energy resources are needed.

Landfill regulation and efforts to contain costs led to the creation of huge regional landfills, which accept waste from many cities. In many cases, the landfills accept waste from other counties or even other states. Waste is often transported long distances for disposal, where it is readily forgotten by the public. As a result, there has been little public interest regarding the environmental impacts of long-distance waste transport and the generation of greenhouse gases inside landfills. Landreth (1995) explains why: "The United States is land rich. That means it's easy to put waste in a landfill where they're out of sight, out of mind." The reality is that relatively little is known about our nation's primary solid waste disposal method. The federal government has no plans to remedy this situation with additional research on landfills.

In contrast, European nations are not only studying landfilling practices, they are taking steps to reduce the use of this method. Several nations have already curtailed landfilling of food, paper, textile, and other waste that undergo biological processing, creating methane and leachate. Some currently have goals to use landfills only for the materials that remain after recycling, comporting, 
and incineration. The restrictions are resulting in significant increases in the number of waste-toenergy combustion plants and biological waste management facilities, including comporting. Policy makers at both the local and national levels should monitor these developments to assess the value of such strategies for U.S. waste management.

\section{Landfill Reuse}

Many people associate the idea of reusing landfills with developing a golf course, park, or wildlife preserve over a closed landfill. Since the mid-1980s, however, several states have explored innovative ways of reusing landfills - as new landfills. In 1995, Landreth summarized the potential benefits of mining and reusing landfills:

When [the landfill has stabilized], you've got a compost-like material you can use as a soil amendment. You can mine the landfill for raw materials such as glass or metals that have some market value. If you do that, you wind up with very little material left there. Then you can go in and update the containment system, use the same site, and start over. It's a good way to generate new landfill space at very low cost. EPA is planning to demonstrate the concept at a couple of locations during the next 10 years. $^{40}$

An early experiment in landfill mining occurred in 1987 in Collier County, Florida (Cobb and Rucksthul, 1988). Using conventional materials separation equipment, researchers recovered plastics and soil, which was used again for daily cover at the landfill. They concluded that landfills could be mined in a safe, economical, and environmentally sound manner. In 1992, EPA completed a similar demonstration of landfill mining at the Collier County landfill. The EPA study showed that ferrous metals, aluminum, and plastics could be mined and recycled. Only the ferrous metals could be marketed without additional processing, however.

Other states are developing methods for accelerating waste decomposition inside landfills so they can reuse the landfills within a relatively short time. Once landfills reach stability, they can be excavated to recover a compost-like residue from biological processing, the daily cover, and other materials such as ferrous metals.

The Delaware Solid Waste Authority began an experiment in 1990 with the reusable landfill concept at its central solid waste facility. Two identical 1-acre landfill cells were filled with 9,000 tons of residential solid waste. In one cell, the leachate was removed; in the other, it was recirculated. The second cell produced ten times more landfill gas in 5 years than the dry cell. After 2 years, tagged materials were removed from both cells and analyzed. Food and paper wastes in the cell with recirculated leachate had substantially decomposed; almost no decomposition had occurred in the dry cell. Vasuki (1996), chief executive officer of Delaware's Solid Waste Authority, explains why his state is interested in developing the reusable landfill concept: "Once landfill gas production begins to subside in a system like this, it's an indication that we can exhume the landfill and use the same space again. The pumps and roads will still be there. Because we can reuse the infrastructure, it will be less expensive than building a new landfill. Just like in your house, we'll have to replace the flooring [liners] every 20 years." After the experiment is completed, the Authority plans to seal both cells with plastic caps, then create a cap failure after four years. The Authority's goal is to

\footnotetext{
${ }^{40}$ EPA canceled its plans to demonstrate landfill mining and reuse in 1995.
} 
compare the environmental impacts from a catastrophic failure of a stable landfill and a landfill that is still undergoing biological processing.

\section{Siting}

Siting landfills near populated areas can be difficult because of public opposition. A 1990 survey (SRI International 1992) showed that nearly two-thirds of those asked would object to siting a new landfill in their community. However, the trend toward building larger, regional landfills in remotely populated areas has reduced public opposition to siting facilities. Vasuki (1996) explains:

The farther away we take our trash, the safer we feel. The idea of putting a landfill in a remote county with a low population appears worthwhile. For example, Charles City County in Virginia has a population of 35,000 or so. When one of the private companies went there wanting to build a landfill, they offered the county a dollar and a half a ton as the "host community fee." So, if you have about 5,000 tons a day coming in, that's about $\$ 7,500$ a day revenue to the county. What the fee did was eliminate all county property and school taxes. The county's rural population didn't see the landfill as a problem.

There are still technical issues to be addressed in siting landfills. The issues include the evaluation of local climate, annual precipitation, local geology, soil properties, vegetation, surface and groundwater characteristics, and the impact of the landfill on wildlife. In planning a landfill, it is important to figure out likely migration pathways for leachate and landfill gas. This information facilitates the design of drainage and containment systems. Soil analysis is crucial for selecting liners and covers for the site.

\section{Air Emissions}

Landfill gas is primarily composed of methane and carbon dioxide - the two most important greenhouse gases. Landfill gas also contains compounds that could contribute to urban smog if uncontrolled. Unfortunately, there are few, if any, reliable measurements of air pollutants emitted from landfills. Standard methods for collecting air samples from landfills have not yet been developed. Consequently, there is no objective way to accurately assess the amount and composition of landfill emissions, much less their impact on the environment.

Even though data are lacking, EPA analysts believe landfill emissions may be significanteven from landfills with gas collection systems. And the majority of landfills do not even collect landfill gas. To make matters worse, landfills emit air pollutants for many years, according to Argonne National Laboratory's Jean Bogner (1995): "We have a 30 to 40 year history of controlled landfilling. All the landfills we initially studied are still producing landfill gas, some at very high rates. Landfill gas generation has a very long time frame." Landfills generate more uncontrolled air emissions than waste-to-energy plants (Jones 1994). In addition, there is no way to assess how long a given landfill will produce emissions (Wiles 1995-1997).

Landfills may be the single largest source of methane emissions related to human activity in the United States, accounting for about $35 \%$ of total U.S. methane emissions, according to EPA estimates (Thorneloe 1996). If so, this is cause for concern: Methane is about 25 times more effective in trapping heat in the atmosphere than carbon dioxide. Regulations under the Clean Air Act require that large landfills reduce methane emissions by $40 \%$ to $45 \%$ by 2000 . In practice, the regulation means that nearly $10 \%$ of all MSW landfills will be required to control landfill gas emissions. The 
regulation is part of the nation's effort to meet goals set at the 1994 Earth Summit for reducing the emission of greenhouse gases.

\section{Carbon Storage}

Some landfill researchers suggest that landfills may store carbon-based (organic) materials for aeons - a kind of reverse coal mine, if you will. Even older landfills, which decompose waste far more readily than modern facilities, contain a substantial amount of undecomposed material such as newspaper or food. Landfills also contain plastics, fertilizers, pesticides, and other organic materials that resist biodegradation and accumulate inside the landfill, possibly for millennia. The buried organic materials are wasted energy resources.

\section{Landfill Stewardship by Future Generations}

Landfills can take many decades to reach stabilization, which means that state and local governments must maintain landfills in good condition for a long time or risk environmental contamination when poorly maintained systems fail. Even landfills that have been shut down can still pose a significant risk. Simon Friedrich (1995) of DOE's MSW program explains the possible impact on future generations: "An issue that is often ignored is generational stewardship for air, land, and water. Our descendants will be monitoring and maintaining the very large landfills we are operating today, just as we are responsible for older facilities."

At the end of 1996, two-thirds of the nation's MSW landfills still lacked liners and other safeguards designed to prevent groundwater pollution (Bender, 1997). Thousands more poorly designed operating landfills were closed, but their impact on the environment continued unabated. Waste buried for decades still contributes to air and water pollution. EPA's 1991 Subtitle D regulations did not solve the problem of pollution from landfills lacking basic safeguards. The regulations merely ensured that new landfills would be required to protect the environment from landfill pollution.

Older landfills can create problems ranging from minor annoyances to significant environmental pollution. The problems include landfill gas emissions, water pollution, and settling, which could lead to failure of permanent caps, and in rare instances, explosions or fires. At present, little is being done to document the extent of these problems or to remediate them.

Fortunately, not all older landfills create serious environmental problems. Waste varies and conditions inside landfills are different. When problems do occur, however, state and local officials are responsible for solving them. In the past, it has proved difficult to find owners and operators of closed landfills, much less hold them liable for pollution from their facilities. There is no reason to believe this problem will disappear in the future.

One way to get a high return on an investment in a new landfill is to fill it up as quickly as possible, hand it over to the state, leave some money to take care of future problems, and leave. EPA regulations require some kind of financial assurance from private companies that they can afford to take care of any problems that occur in the future. However, this assurance is sometimes nothing more than a company balance sheet or shares of stock, according to some solid waste industry officials. Vasuki (1995) explains why this is problematic:

Landfills are created by different companies, one for a given landfill. When the facility closes, the company often closes its door, too. Legally, they're supposed to leave some money behind to maintain the landfill. But who does this maintenance? The company is no longer in business, so [maintenance] reverts to the county or state. 
The state government is responsible whether the landfill was originally private or public. Unfortunately, most states don't look at it from this viewpoint.

If a landfill operator has gone out of business when the facility's bottom liner ruptures 50 or 60 years after the landfill closes, the state will be responsible for fixing the problem, which could be an expensive proposition, unless the landfill operator has left behind real money to take care of the problem. The only practical way to ensure that money is available is to require landfill owners to set up trust funds administered by the state for this purpose. EPA has been reluctant to impose this particular method of financial assurance on landfill owners. Future generations may suffer from this lack of foresight.

Landfills are enormously complex chemical and biological systems, and they remain poorly understood. Federal regulations have mandated important and necessary steps to prevent water pollution. However, these measures also slow the internal biological processing that occurs naturally in a landfill. At present, no one knows how long modern sanitary landfills will take to reach stability.

Current landfill technology has been developed largely on an ad hoc basis at specific sites in response to EPA regulations. Many controls were implemented before the problems they were designed to solve were fully understood. Consequently, there is no assurance new methods will overcome a particular problem in perpetuity. Future generations will inherit the problems that appear. In the case of groundwater pollution, for example, the addition of covers and plastic liners to keep liquids out of landfills may have delayed rather than solved the problem of groundwater contamination. The liners will eventually degrade and begin to leak - quite possibly long before the landfills have become stable and stopped producing leachate.

Better landfilling methods reduce the risk of these occurrences in the present, but do little to mitigate them in the future. If landfills are ignored after the required 30-year period, there is a good chance the cap will eventually fail, according to Vasuki (1996). Vasuki recommends postclosure maintenance for longer than the 30 years prescribed by EPA. According to him, Swedish officials now recommend 600 years of postclosure care for MSW landfills.

\section{Landfill Methods (1950-1995)}

Engineers developed several methods of sanitary landfilling in the 1950s: area, trench, ramp, and cell. Local topography often determined the particular method used at a given site. The area method was used in flat areas, in gently sloping terrain, and in quarries, ravines, valleys, and other land depressions. Solid waste was deposited on land inside a sanitary landfill, then spread and compacted by a bulldozer. At the end of each day, the waste was covered with dirt obtained nearby. Bulldozers then compacted the earth cover. Clay quarries were an ideal site for the area method because clay prevented water from flowing out of the landfill. If landfills were sited in old sand and gravel quarries, however, artificial liners were used (after about 1980) to prevent groundwater pollution.

The trench method was similar to the area method except that a trench was first cut in the ground to receive the waste. The method worked well on a flat or gently sloping site. Dirt excavated from the trench was used for daily cover. The method was used in flat terrain with a water table well below the surface.

The ramp method was used for burying waste on the side of a hillside. As with other methods, bulldozers spread out the waste and compacted it along the slope. The same equipment was used to obtain dirt for cover from the ground just ahead of where waste was being deposited. 
In the cell method, smaller areas within a large facility were sequentially filled with waste and capped. This method had the advantage of allowing landfills to collect and use landfill gas from completed cells before the entire landfill was closed.

\section{Shredfills and Balefills}

In the 1970s, several cities experimented with shredding or baling waste before depositing it in a landfill. In the former method, solid waste was pulverized in a mill after ferrous metals had been removed. The refuse was then spread evenly inside a landfill, called a shredfill. Shredfills attracted fewer vermin, experienced fewer fires, and extended landfill life. The United States had more than 100 shredfills during the $1980 \mathrm{~s}$, but the method never became widespread because of its high cost.

In the balefill method, solid waste was compressed into bales about 50\% denser than conventionally compacted waste. Bailing was done on site, at a transfer facility, or at a materials recovery facility. The dense bales were stacked closely together inside the balefill, where they extended landfill life and reduced problems with vermin, fire, and blowing trash. The facility was less expensive to operate than a conventional landfill, but the high capital cost of baling equipment offset operations savings.

\section{Landfills Built after 1990}

Landfills built after 1990 must comply with state and federal regulations. They must contain the following components: (1) liner systems, (2) leachate treatment and collection systems, (3) groundwater monitoring systems, (4) daily and permanent covers, (5) landfill gas monitoring and collection systems, (6) landscaping to improve the aesthetics of the facility, (7) security systems, and (8) plans for protecting the area after the landfill closes and eventually returning the site to the community. Some landfills also have energy recovery systems.

The development of a new landfill begins with siting and permitting. After a site is chosen and necessary permits obtained, planning and design take place. Planning includes a comprehensive analysis of the site's geological characteristics, proximity to land and surface water, and soils. Once this phase is completed, construction begins. Roads and buildings are constructed and the fill area is prepared to receive waste. Liners and drains are put in place.

Landfill operation begins when the first load of waste is deposited and ceases after the last load is accepted. This phase may last years or decades. During the time a landfill is open, it bustles with activity. Trucks line up to dump waste 5, 6, or seven 7 days per week. Bulldozers and other equipment compact the waste and add cover at the end of each day. Gas collection wells are installed as needed, and technicians monitor landfill gas and leachate production. While in operation, MSW landfills must adhere to the following rules:

- Landfills must have run-on and run-off controls for water.

- Landfills must prevent discharges to surface water.

- Landfills may not accept hazardous waste.

- Landfills may not accept most liquid waste.

- Waste must be covered daily with soil or an acceptable substitute.

- Rats, insects, and other vermin must be controlled. 
- Open burning is not allowed except under clearly defined circumstances.

- Public access to landfills is restricted.

- Landfills must have a monitoring system for methane gas.

- Landfills must keep detailed records of operation.

A landfill is closed and capped after it is full. Gas and leachate monitoring, collection, and treatment continue for at least 30 years. During this time, the landfill may be converted to other uses and returned to the community. After three decades, the facility may or may not have reached stability, but it typically receives no further special attention because federal regulations no longer require it.

\section{Liner Systems}

Liners are a major defense against the migration of landfill gas and leachate out of a landfill into surrounding areas, the atmosphere, and groundwater. They are also a defense against water getting into a landfill.

EPA and state regulations require natural, synthetic, or composite liners. Compacted clay soils are widely used to line MSW landfill sites because they are relatively impermeable to water. The liners work fairly well when installed properly. If not, they are more permeable to liquids than expected and can result in groundwater contamination. Other materials used as landfill liners included asphalt concrete, soil cement, soil asphalt, bentonite clay, spray coatings, soil sealants, or special chemicals designed to absorb liquids. These materials are strong enough to bear the weight of compacted waste and heavy equipment. They can also withstand chemical attack. Liners made from such materials are often constructed at the landfill site using the natural soil at the base of the landfill.

Synthetic liners, including the primary liner in a composite system, are usually flexible membrane (plastic) sheets anywhere from 30 to $60 \mathrm{~mm}$ thick. In a composite system, the plastic sheet is installed over a secondary layer of compacted clay soil at least two feet thick. In some landfills, a geotextile liner may be placed above the plastic liner. It provides a drainage layer and helps protect the landfill's primary liner. Synthetic liners must be free of holes, rips, or punctures. Seams must be sealed in the field to create strong, leak-resistant joints. Plastic liners are covered with soil after installation to protect them from deterioration. The soil liner provides backup protection in case the plastic liner springs a leak. Soil liners are compacted to make them flat, to get rid of holes and protrusions, and to make it harder for liquids to pass through them. Clay liners are often used along the bottom and sides of a landfill to create a barrier to liquids.

\section{Systems for Collecting and Treating Leachate}

Leachate collection and treatment systems manage leachate so it can be safely discharged to a wastewater treatment plant or other destination. Collection systems can also recycle leachate back through a landfill, which reduces treatment costs. New landfills are designed to avoid a buildup of leachate at the bottom of the landfill. Drainpipes are often installed between the upper and lower liners. Perforated pipes collect and carry the leachate to storage tanks or a treatment facility.

If it is not recycled back through the landfill, leachate is managed by evaporation or municipal wastewater treatment. Evaporation in lined ponds is the simplest way to manage leachate. However, many landfills discharge leachate for treatment at a conventional wastewater treatment facility. The leachate is pretreated to remove organic material before being sent to the treatment 
facility. Recirculated leachate can often be discharged to a municipal wastewater treatment plant without pretreatment.

Leachate may also be treated on site by methods that are similar to those employed at sewage treatment, plants and consist of filtering, chemical treatment, biological treatment and disinfection. Leachate treatment is often more challenging than wastewater treatment because the composition of leachate is quite variable.

\section{Systems for Monitoring Groundwater}

The risk of polluting wells, lakes, and streams with leachate is a major environmental concern. For this reason, modern landfills are required to monitor groundwater near landfills. Monitoring systems are especially important in landfills that do not have leachate collection systems. They can also be used to collect and test samples of treated water discharged from the landfill site.

Groundwater monitoring systems can be simple or quite complex, depending on the site. In a basic system, holes are drilled below the level of the water table around the perimeter of the landfill. Plastic pipes are positioned vertically inside the holes using gravel, sand, and soil. The bottom of each pipe is permeable to water, which flows into the well, where it is tested regularly for the presence of chemicals from the landfill.

EPA regulations spell out procedures for collecting groundwater samples, preserving and shipping them, and analyzing them for contamination. The regulations also define the chemicals that must be monitored, procedures for dealing with contamination once it has been detected, and methods for evaluating corrective actions.

\section{Daily and Permanent Covers}

Daily cover hides waste from sight, reduces dust and litter, and prevents the spread of disease. It improves the appearance of the landfill, discourages scavenging by humans and other animals, reduces odors, and helps control fires and litter. Soil is normally used for daily cover, but other materials such as crushed glass, synthetic foams, waste combustion ash, landfill mining residues, and waste carpet have also been used in some locations. Soil substitutes must be approved in advance for use as daily cover by appropriate state agencies.

The complex permanent covers, required by the 1991 EPA regulations, are relatively new and have not been installed in many landfills. The covers are designed to prevent the entry of water into a landfill once it has closed, to create an area suitable for revegetation, and to minimize erosion. Cap designs vary significantly from site to site. No one knows how long the new permanent cover designs will remain in good condition. If the landfill should settle after closure, the cap will probably also settle and, unless it is carefully monitored, may develop a breach during the settlement process.

Permanent cover designs incorporate a layer of clay or other impermeable material underneath a soil cover. A typical cap might consist of a $30-\mathrm{cm}$ drainage layer, a 60 -cm layer of compacted clay, a 30-cm layer of coarse sand or gravel, and a top layer of soil $1.5 \mathrm{~m}$ to $3 \mathrm{~m}$ thick. The top layer of soil is necessary for growing plants, which absorb water and prevent the water from seeping into the landfill. The soil and plants also help control erosion.

\section{Systems for Monitoring and Collecting Landfill Gas}

Gas monitoring systems for landfills include procedures for testing the operation of the gas collection system, checking and maintaining gas flares, and measuring gas concentrations at selected locations in and near the landfill. They assess both the quantity and quality of landfill gas produced 
inside a facility. Monitoring systems also provide information about the impact of landfill gas on the environment and help engineers to design energy recovery systems.

The key considerations in designing a landfill gas monitoring system are the size of the landfill and the nature of the solid waste buried there. Larger landfills produce more gas than smaller facilities. Waste that contains lots of food and yard wastes produce more landfill gas than waste rich in paper, plastics, or metals.

The majority of landfill gas monitoring systems continuously test gas production inside the landfill. They also check emissions and gas migration at least once a month. Gas monitoring systems operate long after a landfill is closed. The length of time is either determined ahead of time or tied to a particular level of landfill gas emissions. Gas monitoring is costly, time consuming, and labor intensive. The system relies on multiple wells and expensive laboratory instruments. Less costly alternatives include calculations based on average gas generation rates per set volume of solid waste and the use of single wells or even probes.

The collection of landfill gas is considered as important as installing liners or collecting leachate. Gas collection minimizes emissions of trace gases, carbon dioxide, and methane. It also prevents the migration of landfill gas into surrounding areas, which reduces the likelihood of a landfill gas explosion.

During the 1960s, a few landfill operators began collecting landfill gas and venting it to the atmosphere. Gas collection grew more widespread following several well-publicized explosions that occurred during the 1960s. During the 1970s, some landfills began flaring the gas they collected rather than simply venting it to the atmosphere. A few landfills have recovered energy from landfill gas since the mid-1970s.

Several different strategies are employed to prevent gas from migrating out of a landfill. These include impervious barriers, natural venting, forced venting and hybrid systems. Impervious barriers include cement walls and trenches filled with clay or lined with plastic. Such specially designed liners and trenches prevent landfill gas from migrating horizontally out of the landfill.

Natural venting systems use selectively placed broken pipes or coarse gravel to direct gas flow to a particular area. The gas is allowed to vent to the atmosphere from there. Hybrid systems combine impervious barriers with natural venting. For example, trench vents are often backed up with impervious liners around the periphery of the facility.

Forced venting systems were the predecessors of modern gas collection systems. In a forced venting system, landfill gas is pumped through a piping system. Evenly spaced, perforated plastic pipes collect gas throughout the landfill. Most landfills use a series of vertical wells connected by an array of horizontal pipes feeding into a central gas-flaring station or electrical generation facility. A few landfills use interconnected horizontal gas extraction wells. When energy recovery is the goal of gas collection, the collection system is designed to avoid trapping air with the landfill gas. Gas collection wells are usually drilled when landfilling is completed. In some landfills, particularly those using the cell method, they may be built progressively as waste is added. Collection systems work around the clock, transporting gas from wells inside the landfill into a central processing facility. Depending upon the sophistication of the piping system, the pipes will collect an estimated $30 \%$ to $85 \%$ of the gases generated by the waste.

Most landfills in the United States that collect gas, flare it. Open flares and enclosed flares are both used. The former have a single burner tip located at or above ground level. Enclosed flares have multiple burner heads to accommodate a range of flow rates. 


\section{Systems for Recovering Energy}

A few landfills recover energy from landfill gas. Both flaring and energy recovery result in decreased emissions of methane and trace gases. In addition, energy recovery displaces fossil fuel resources and reduces emissions from coal-fired power plants.

Landfill gas can be processed and sold as a substitute for natural gas, used as a boiler fuel, burned to produce heat, or used to produce electricity with internal combustion engines, gas turbines, or steam turbines to produce electricity. The amount of landfill gas available for energy recovery at a given landfill depends on the facility's gas production rate, how fast the gas migrates through the waste before reaching a well, and the collection efficiency of the facility's gas recovery system.

Landfill gas can be upgraded to pipeline quality natural gas by removing water, carbon dioxide, and other corrosive contaminants. Both chemical and biological methods can be used to clean the gas. Once cleaned, the landfill gas can be added to utility supplies if this is allowed. Otherwise, it can be used as vehicle fuel or as a raw material for making methanol, an alcohol fuel.

Landfill gas can be used to generate electricity with internal combustion engines, gas turbines, and steam turbines. Internal combustion engines are the technology of choice when gas supplies are too low or erratic to make it economically feasible to use steam or gas turbines. The engines must be specially modified to counter the corrosive effects of landfill gas.

If gas recovery rates are high, gas turbines are often the technology of choice for electricity generation. Because gas turbines are reliable and have low emissions, large landfills often use them. The high concentration of carbon dioxide in landfill gas is an advantage with gas turbines. It adds volume to the gas flow and increases the output power of the turbines. In many instances, corrosive landfill gas is cleaned up with activated charcoal before it is used to run gas turbines.

Steam turbines are also used to generate electricity from landfill gas. They require water treatment facilities, cooling towers, water disposal, pumps, and boilers. Only the largest landfills use steam turbines to recover energy from landfill gas.

The efficiency of landfill gas-to-electricity systems is about $33 \%$. When electricity and heat are both produced, the efficiency of energy recovery jumps to $80 \%$ to $85 \%$ - efficiencies comparable to fossil fuel generation. Electricity production can occur at all landfills with reasonable access to utility lines. Heat production from landfill gas is limited to landfills located within about three miles of users due to the high cost of transporting either landfill gas or steam.

Pretreatment to remove water and filtering to remove dust allows landfill gas to be used as a boiler fuel. Industries, prisons, schools, hospitals, or other institutions with large heating requirements can use landfill gas to run their boilers. Landfill gas can be directly fired in lime or brick kilns. Burners used in this application are similar to those used for natural gas, except they have larger jets to compensate for lower energy content of landfill gas.

\section{Landfill Gas-to-Energy Industry}

Most commercial landfill gas-to-energy systems produce electricity. In 1995, there were 115 energy recovery projects at U.S. landfills, nine in Canada, and more than 250 projects worldwide. EPA collects detailed information on U.S. projects and makes it available to those interested in developing new landfill gas-to-energy projects.

Although the United States has about $40 \%$ of the world's commercial landfill gas-to-energy plants, fewer than $5 \%$ of the nation's landfills operate landfill gas-to-energy plants. The 200 largest landfills, with capacities in excess of 1,000 tons per day, are the most likely to include energy recovery facilities. The quantity of gas generated by them is sufficient to justify the expense of producing electricity, process heat, or pipeline-quality gas. 
California has most of the landfill gas-to-energy projects. Twenty-seven other states have at least one facility. About $70 \%$ use internal combustion engines to generate electricity, and most projects produce less than $5 \mathrm{MW}$ of power. The Puente Hills facility in Whittier, California, is the largest producer of electricity. The steam-turbine power plant's capacity is $50 \mathrm{MW}$. In 1992, landfillgas-to-electricity projects recovered 1.2 million tons of methane and produced about $344 \mathrm{MW}$ of electricity (Thorneloe March 1992a).

The landfill gas-to-energy industry was born after natural gas prices skyrocketed during the 1970s in response to perceived energy shortages and the deregulation of natural gas prices. Landfill owners and operators began exploring the use of landfill gas as a competing fuel for natural gas. So long as natural gas and oil prices remained high, landfill gas-to-energy projects were profitable. When natural gas prices fell during the early 1980s, the majority of landfill gas-to-energy projects switched their focus to the production of electricity. At the time, many utilities needed additional supplies of electricity. PURPA required them to purchase power from independent power producers in lieu of adding new capacity. Landfill operators were able to negotiate very good prices - in the range of $\$ 0.10$ to $\$ 0.12 / \mathrm{kWh}$ - for their electricity.

During the early 1980s, Congress enacted tax credits for renewable energy production. The tax credits initially had little impact on landfill gas-to-energy projects because electricity costs were high. Around 1990, however, contracts guaranteeing high prices for electricity expired. Utilityavoided costs (the amount a utility was required to pay for electricity from an independent power producer) fell to $\$ 0.04 / \mathrm{kWh}$ or less. Even the largest landfill gas-to-electricity projects suddenly needed the tax credits to stay out of the red.

As the tax law was written, landfill owners were not eligible for tax credits for landfill gas-toenergy projects, however. Neither were utilities. Because tax credits were now important for maintaining the economic viability of landfill gas projects, third-party investors began to finance them. What few revenues and profits could be realized from energy recovery projects were divided among many entities.

The conversion of landfill gas-to-electricity or heat may not be economical even in large landfills with high gas production rates. Natural gas prices have remained consistently low since the mid 1980s. In addition, the cost of complying with air, water, and solid waste regulations has reduced the profitability of landfill gas-to-energy conversion. The creation of pipeline quality gas, with its high operating costs, has been particularly hard hit by current energy prices. Electricity production is somewhat more economical, provided projects are sized larger than $1 \mathrm{MW}$ and the price paid for electricity is at least $\$ 0.06 / \mathrm{kWh}$ (Thorneloe 1992a).

The widespread installation of landfill gas-to-energy systems is not likely to occur unless electricity prices rise significantly, which is unlikely given the impending deregulation of the utility industry. Requirements to keep landfills dry is an additional factor working against gas recovery in modern landfills. Unless the landfills recirculate leachate, gas generation rates will occur slowly over a long period of time. Because the dry conditions inside the landfill retard biological processing, there may not be sufficient gas produced during a given period of time to justify the cost of installing an energy recovery system. The good news is that the large landfills comply fully with federal regulations and are protecting groundwater and reducing emissions, at least in the short run. However, their long-term environmental and economic impacts will be problematic when liners and covers begin to leak, biological processing speeds up, and landfill gas formation increases. 


\subsection{Waste Management Today}

Much of the conventional wisdom about garbage disposal consists of assertions that turn out, upon investigation, to be simplistic or misleading. ${ }^{41}$

Solid waste management has undergone significant improvements since 1965. In many cities, larger and more efficient integrated solid waste management systems are used to protect human health and environmental quality, keep costs reasonable, and provide reliable service to increasing numbers of customers. Through our most sophisticated solid waste management systems, we are already exploring innovative methods for using natural resources efficiently and preventing pollution.

Even so, Americans could still make more efficient use of material and energy resources, while safeguarding air, water, and other natural resources. One strategy for accomplishing these goals would be to integrate solid waste management with manufacturing, agriculture, energy, transportation, and other community services. Such a visionary step would almost certainly require federal leadership, yet as of 1997, there was no federal MSW program.

The federal MSW program provided intermittent and inconsistent support for improved solid waste management from 1965 until the program's demise. Early on, the federal program led states to initiate long-term planning for solid waste management. The government lost interest in the planning process after about 15 years. Funding for state planning was eliminated in the early 1980s, and EPA stopped reviewing state plans. EPA's activities in solid waste research and development were started and stopped several times between 1965 and 1995. DOE's MSW program, which had supported research and development of new technologies for more than 20 years, was terminated in 1997.

N.C. Vasuki, chief executive officer of Delaware's Solid Waste Authority, is frustrated by inconsistent federal support for solid waste management planning and implementation. Vasuki (1996) believes that long-range planning, research, and development are needed for better resource management and pollution prevention:

Congress started the right way by requiring that states submit plans to EPA for controlling air pollution, water pollution, and solid waste. EPA reviewed the plans, and states redid their plans based on its suggestions. Delaware got involved in this early on, about 1976 or 1977 . We developed a long-range plan we could implement. Then after Reagan got elected, EPA lost interest in municipal solid waste and stopped looking at state plans. Now we have a big problem because Congress and industry don't look 15 years ahead. They only look about two years in the future.

It's wrong to landfill $75 \%$ of our waste. It's the reverse of coal mining. We're burying Btus in the ground. The problem is that we look at nature in thin slices. We need a wholistic approach to our lifestyle and our environment. It's not just air pollution, or ground water contamination, or transportation. We never look at the

Perennial, p. 28. 
whole environment at one time. There is a bright side, though: the United States has become accustomed to recycling. It's a good habit that won't disappear.

\section{Integrated Waste Management}

Thousands of American cities and towns already practice some form of integrated waste management, which includes coordination, planning, and public education in addition to solid waste collection, transport, and management. The key feature of integrated waste management is its systems perspective; a community that uses more than one solid waste management method does not necessarily have an integrated system. Lanny Hickman (1995-1997), formerly of SWANA, offers his perspective on how integrated solid waste management evolved:

I've been in the field since 1966, and back then it was a "carry and bury" business. Now it's a carry, bury, shuffle, burn, sort, and every other kind of business. All sorts of new people are coming into the field. These changes have come incrementally. When we had to go too far to landfill, we added transfer systems. Then recycling came along. At first these were independent actions. Now they're [becoming] more integrated. The main principles of integrated waste management, which everyone seems to forget, are planning and financing. The four methods [waste minimization, recycling, waste combustion, and landfilling] depend upon these two principles.

In an integrated approach, each local government selects solid waste management methods that meet its needs, then coordinates these methods for maximum efficiency, reasonable cost, and acceptable environmental impacts. With such a strategy, sparsely populated western states might emphasize the use of landfills and limit recycling. Unless there are remanufacturing facilities and users of recyclables nearby, recycling may not make sense environmentally or economically. In contrast, a large urban metroplex might encourage remanufacturing industries, build a large waste-toenergy combustion plant, and minimize landfilling.

Don Walter (1994-1995), formerly of DOE, outlines the considerations favoring an integrated approach to solid waste management:

You have to start looking at solid waste management from a life-cycle perspective. Recycling paper when you have to haul it a long way doesn't look so good. Putting it in a landfill isn't all that bad except it's terribly inefficient from an energy perspective. And its long-term environmental impact scares me. I would much rather burn a ton of paper than put it in a landfill. If I could recycle it in Washington, D.C., then it makes sense to recycle it in Washington. If I have to haul it 1,500 miles to make new newsprint, then I've increased the use of fossil fuel, increased sulfur dioxide in the air, and made the [global warming] problem worse.

Ideally, integrated solid waste management systems should be designed from scratch to manage solid waste in the most efficient, environmentally sound, and economical fashion possible. Even when integrated systems evolve gradually over time, as many have today, they frequently offer economic and environmental advantages over systems that eschew systematic planning. Local governments profit from increasing efficiency and lowering costs whenever opportunities arise. Opportunities come in many forms, including contract negotiations with private industry, new technologies, and participation in regional solid waste management system development. 


\section{Goals}

EPA and DOE have endorsed integrated solid waste management (IWSA 1994), the goals of which include:

- Regional cooperation among local governments in developing solid waste management facilities

- The use of source reduction and recycling to reduce the amount of solid waste generated

- Energy recovery from solid waste not suitable for recycling

- Landfilling of solid waste and other residues.

The Council of State Governments has also endorsed integrated solid waste management. The council supports the idea that reuse, source reduction, recycling, waste-to-energy, and landfilling are all necessary for effective solid waste management. Local governments and private businesses that manage solid waste on a day-to-day basis use one or more of these solid waste management methods.

\section{Linking Recycling and Waste Combustion}

The move toward integrated solid waste management is reflected in current strategies linking recycling and solid waste combustion. The 1996 IWSA Municipal Waste Combustion Directory of United States Facilities (Taylor and Zannes May 1996) showed that local governments with wasteto-energy plants had average recycling rates of $26 \%$, which is higher than the national average of $22 \%$. Local governments using this combination of solid waste management methods also exported significantly less solid waste to other states to put in landfills.

The majority of waste-to-energy plants operated profitably in municipalities that offered curbside or other recycling programs. The key was planning for the right amount of waste management capacity and establishing reasonable recycling goals. In areas where excess waste combustion capacity was planned before recycling reached its current high levels, plant operators had to deal with overcapacity problems by contracting for solid waste from additional communities in the region.

In 1995 , more than $90 \%$ of the nation's waste-to-energy facilities had on-site recycling for ferrous metals. Some also recovered and recycled non-ferrous metals. Removing and recycling metals enhanced the value of the remaining solid waste as fuel and resulted in fewer operations and maintenance problems. The availability of waste-to-energy combustion also provided a hedge against unstable markets for paper and plastics. In a number of communities, tipping fees at the local wasteto-energy plant included surcharges to pay for curbside collection, yard waste composting, and other recycling services. According to Walter (1994-1995), at least one community was using its profits from waste-to-energy combustion to finance its paper recycling program, which was losing money.

\section{Solid Waste Management Issues}

Solid waste management issues are a function of politics, economics, and national policy rather than of critical technological barriers. The issues include landfilling practices defined by regulation rather than by scientific understanding, local control of solid waste management, federal solid waste regulation, the need for applied research to develop better solid waste management practices, and the need for a national policy on materials and solid waste management. 
The demise of the federal solid waste program has complicated the search for better solid waste management solutions. The problem is that solid waste management professionals simply do not have all the information they need about current methods to adequately plan for the future. If they did, planning would be easier. With the benefit of hindsight, Walter (1994-1995) wishes DOE had adopted long-term strategic goals for its MSW program: "From the earliest days of the federal MSW program, we should have been trying to move toward maximizing energy recovery, maximizing volume reduction, minimizing environmental impacts, and maximizing returns on industry's investments in waste management."

\section{Landfilling Practices}

Despite its historical significance as a public issue, there is no shortage of landfill space. As long as crowded urban areas are willing to send their solid waste as far as necessary, the nation could continue to bury most of its solid waste on a tiny fraction of its acreage. There are, however, important considerations about landfilling as the nation's primary solid waste disposal method. For instance, the nation should not ignore the long-term environmental impacts of landfills.

No one knows the extent of landfill gas emissions to the atmosphere. In a study scheduled for completion in 1998, the Energy Information Agency compiled data from U.S. and European studies to better estimate these emissions. At the same time, EPA developed better methods for measuring actual landfill emissions. The two initiatives are expected to help policy makers make informed decisions regarding landfill emissions control.

There are no plans for addressing the risk posed by landfills to air and water quality in the future. Unless provisions are made to maintain landfills in good condition for decades beyond the 30 years required by EPA regulation, landfills will eventually leak and contaminate the environment. Modern landfills accept thousands of tons of solid waste per day. In accordance with EPA regulations, they are designed to be as dry as possible. Waterproof liners and covers keep water out, and pumps draw off moisture that forms inside the landfill. The goal is to keep landfill contents from releasing contaminants into the environment. Unfortunately, these practices are far from ideal for solid waste processing inside landfills. Carlton Wiles (1995-1997) explains: "The best landfill designs allow the facility to operate as a bioreactor. What you want to do is create the right conditions for degrading waste anaerobically. That way you speed up stabilization, both biologically and chemically. You get more landfill gas. Waste degrades to a more stable form. Unfortunately, the Subtitle D regulations have impeded the implementation of these types of landfills."

Many experts agree that keeping moisture out of landfills is a dangerous practice because it delays stabilization. As long as biological processing is incomplete, the failure of landfill caps and liners could lead to serious pollution at any point in time. Vasuki (1996) thinks future landfill contamination is the primary challenge facing solid waste management professionals:

EPA regulations assume that a landfill is safe when it has been monitored for 30 years after it closes. This assumption is not correct. When nobody's looking, that's when problems start. Caps fail, rainwater gets into the system, and leachate forms. Because [leachate] is not pulled out anymore, it will find the path of least resistance - into the groundwater.

A boiler is a good analogy for a landfill. If you maintain it for 30 years, then stop and restart it sometime later, you're going to have explosions. So, what do we do now? 
We should try to stabilize landfills as quickly as possible so even if there are future problems, they won't be as bad.

When landfills are deliberately kept dry, concentrated leachate may accumulate inside the facility, particularly once the leachate collection and treatment system ceases operation. At some point, the landfill liner may be breached. Or a cap may crack, allowing rainwater into the landfill and generating high levels of biological processing and leachate formation. The leachate will then contaminate the environment once the landfill's liners inevitably begin to leak.

By the time such events occur - many decades after a landfill closes - the landfill may be forgotten. Leachate containment may no longer be possible. At present, EPA requires landfill operators to monitor their facilities for only 30 years after they are capped. Although states have the option to require longer monitoring and maintenance, few have done so. Leaks and subsequent serious environmental contamination could occur 50 or even 75 years after monitoring ceases. It is unfortunate that there may not be money available to fix those problems. Hickman (1995-1997) explains:

The Subtitle D landfill rules had provisions to guarantee that future generations wouldn't have a problem with landfills, because [landfills] are supposed to be monitored and have financial assurance. There's supposed to be money there to take care of them. But EPA has diluted the financial assurance provisions so much that there will be no money to fix another generation of landfills when something does occur. We're right back where we were before. It took us 30 years to get here, and EPA has basically destroyed it. There are a few states that require trust funds, and maybe that money will be there. But most states [do] not because the feds have waffled so much that there's no requirement.

Researchers and sanitary engineers have argued for a long time in favor of wet landfill designs, in which leachate is enriched with microorganisms and recirculated through landfilled solid waste. Recirculating leachate for even 5 years greatly enhances methane production and transfers most of the by-products of solid waste decomposition into the leachate. The leachate can then be removed and treated. The advantages of this strategy include significantly reducing the environmental impacts of future leaks, if they occur, and minimizing uncontrolled gas production (Uehling 1993). Vasuki (1996) explains why Delaware is one of about a dozen states that have implemented leachate recirculation systems in some landfills:

Leachate contains lots of nutrients. Anaerobic bacteria like it when you feed them back the nutrients. If you recycle water back through a landfill, the biological activity is enhanced. I think this works because when bacteria first begin to break down waste, they produce complex molecules. If you send everything back through a second time, the bacteria can further reduce the size of these molecules and eventually fully convert them to methane and carbon dioxide. In experimental landfills, this system works very well. 


\section{Flow Control}

The use of flow control began in the late 1970s when solid waste combustion facilities were replacing old-style incinerators. Flow control ordinances and contracts allow a local government to designate specific facilities where solid waste is to be delivered for processing, treatment, or management. Destination facilities may be publicly or privately owned. The ordinances were designed to ensure that a designated facility received a guaranteed amount of solid waste. If the receiving facility charged a tipping fee for the solid waste, then flow control also guaranteed a source of revenue. Steve Levy (1995) explains the origin of flow control:

Most cities purchased new waste-to-energy facilities as turnkey, full-service operations. In essence, cities turned over these plants to the private sector to operate. When you give a facility to somebody else, you have to guarantee the waste with what we call "put or pay" contracts. If Ogden Martin is going to operate an incinerator for Alexandria, Virginia, at 975 tons per day, and get paid \$52 [for each] ton that comes in, Ogden doesn't want the waste to drop to 700 tons per day the next year because they're recycling 275 tons a day. If the plant is designed to operate at 975 tons, it won't do well economically with only 700. Operated at full capacity, the plant collects $\$ 50,700$ a day in tipping fees. This figure drops to $\$ 36,400$ at 700 tons per day.

Flow control is common in areas with waste-to-energy plants. These expensive facilities require large amounts of solid waste to operate efficiently and profitably. The agreements protect the community's investment by ensuring long-term receipt of enough solid waste to repay construction loans and cover operating costs. In a few instances, state recycling goals and waste diversion mandates for yard waste have also fostered the use of flow control.

Flow control may be used to generate revenues to support various elements of an integrated solid waste management system. Local governments can use the revenues for source reduction programs, curbside collection for recycling, household hazardous waste collection, solid waste planning, and public education. Such program costs are built into the tipping fee of the facility to which solid waste is directed. Tipping fees may be higher than the market level, but flow control prevents haulers from taking solid waste to facilities with lower tipping fees.

In September 1992, Congress directed EPA to evaluate flow control as a means of managing MSW. EPA was asked to compare solid waste management in states with and without flow control, identify the impact of flow control on public health and the environment, identify its impact on the development of new waste management capacity, and assess its impact on meeting source reduction, reuse, and recycling goals.

EPA determined that 35 states, the District of Columbia, and the Virgin Islands permitted flow control, but not all of them actually had flow control in place. More than 82 facilities (managing 2.5 million tons of solid waste) had solid waste guarantees as part of contractual arrangements, which were sometimes supported by flow control. Flow control appeared to have little or no effect on public health and the environment.

EPA discovered that flow control played a limited role in solid waste management, impacting only waste-to-energy facilities and recycling programs using materials recovery facilities. Nearly one of five MRF-based recycling programs and almost two of every three waste-to-energy plants were supported by flow control in 1992. The majority of MRFs supported by flow control were located in the Northeast. 
Flow control played a major role in the waste-to-energy market until the mid-1990s. Nearly $60 \%$ of solid waste going to waste-to-energy plants was supported by flow-control. Another $31 \%$ was guaranteed by contracts, which, in turn, were often supported by flow control. With nearly $90 \%$ of its solid waste guaranteed by flow control, the waste-to-energy industry was particularly vulnerable to challenges mounted against it.

In May 1994, the Supreme Court (C\&A Carbone v. Town of Clarkstown) declared that flow control laws were unconstitutional. The lawsuit was brought by a hauler who wanted the freedom to take his solid waste to a less expensive landfill rather than to a waste-to-energy plant. At first, the Supreme Court decision appeared to be a major setback for both the waste-to-energy industry and local governments relying on the technology for solid waste management. Right after the decision was announced, solid waste projects went on hold across the country. Haulers in other parts of the country sued for the right to deliver solid waste to the least expensive site. Industry analysts raised valid concerns that the Supreme Court decision might lead to an increase in landfilling, currently the least expensive MSW management option.

In response to these developments, Congress began debating new flow control legislation to protect municipal investments in waste-to-energy plants. However, Congress did not pass a new flow control law in 1996. And the Carbone decision appears to have been a paper tiger. To begin with, local governments have figured out ways to circumvent the decision, according to Levy (1995):

There are ways around this court decision. In Montgomery County [Maryland], for example, the hauler signed a contract with the county specifying that he will take his solid waste to the county's MRF at Shady Grove. But where I live [out near Olney], we don't have [a contract like] this. The hauler can take my waste down to Fredericksburg [Virginia] and save \$200 a truckload. So to deal with this, the county puts the Shady Grove MRF tipping fee on my tax bill, and lets the hauler take it to Shady Grove and tip it for free. I've already paid for it. That's not flow control. That's regaining control of the waste by putting it in the tax base.

The downside for the county is that this hauler can also go pick up waste over in Prince George's County and take it up to the Montgomery County MRF and tip it for free, because the MRF doesn't know where it came from. He could be picking it up in Washington, D.C. So Montgomery County could be taking all this waste from all over for free and having to pay to get rid of it. There's no easy solution.

The Carbone decision has been eclipsed by two other federal court cases. In Harvey v. Harvey, a third circuit court judge ruled that municipalities could use flow control provided they followed a set of procedures laid out by the court. In the second circuit, the town of Babylon, on Long Island won the right to use its municipal taxing and regulatory authorities to control local commercial and household waste, as well as to contract out for solid waste collection and management. This system is, in fact, a form of flow control. The town not only won its case, but the Supreme Court declined to review it. According to Harvey Alter (1995), this decision took the teeth out of the Carbone decision.

Regardless of whether Congress decides to pass new legislation governing flow control, an EPA study has already identified alternatives to flow control for guaranteeing solid waste deliveries to specific solid waste management facilities. One alternative is for a local government to own and 
operate its own solid waste collection system, as it is entitled to do under the commerce clause of the U.S. Constitution. ${ }^{42}$

If a local government controls solid waste collection, it can deliver solid waste to a designated facility within its own or a neighboring jurisdiction. If a local government prefers to employ a private hauler, then contracts or franchises can be structured to specify the facilities to which solid waste is to be delivered. These alternatives can be financed via property taxes, general taxes, or user fees.

\section{Who Will Control Tomorrow's Solid Waste?}

After more than a decade of unprecedented growth, private companies now own much of the nation's landfill capacity and most of its material processing facilities. Private companies also collect a significant portion of the nation's solid waste and virtually all commercial and industrial solid waste. The question now is: where will private companies find new opportunities for growth in the United States?

One answer to that question is that private companies may attempt to expand by convincing more local governments to turn over responsibility for solid waste collection to them. Municipal officials would be well advised to consider the ramifications of acceding to such requests, according to Hickman (1995-1997). Hickman believes that local governments have made significant contributions to MSW management and to the development of integrated solid waste management. In most instances, private industry would have been unwilling or unable to make those same contributions. For example, state and local governments are responsible for the infrastructure underlying modern solid waste management. This infrastructure was created in response to public needs - for dependable collection, for closing polluting incinerators and open dumps, for better solid waste management technologies, for modern energy recovery plants, for recycling, and for efficient integrated waste management systems. The infrastructure allows private service providers to compete in the solid waste business. But it also allows local governments to compete as well. Efficiency and good service are not the exclusive property of either the public or private sectors. Hickman (1995-1997) explains:

Local governments can choose to be active in solid waste management. But they need to find a way to be businesslike and competitive. During the next decade, you're going to see some local governments active in contracting and franchising. I hope they treat those contracts like a city service, with properly defined controls. I think we're going to see less and less capacity in the public sector. There's nothing wrong with that. Cities just need to learn how to deal with the competitive marketplace. Unfortunately, lots of communities don't want to take this competitive step.

The potential problem arises if local governments abrogate their responsibility for setting solid waste management policies and overseeing the solid waste management system. Local governments should maintain control over public policy, protect the public's interest in controlling the flow of solid waste, keep costs affordable, and ensure that solid waste is managed to protect public health and the environment. Otherwise, the dictates of a particular company's bottom line

\footnotetext{
${ }^{42}$ In February 1996, the Supreme Court declined to review an Appellate Court decision affirming this right in SSC Corp. v. Smithtown, NY.
} 
could supersede the public interest. As Hickman (1996) explained in series of editorials appearing in SWANA's MSW Solutions newsletter:

Deciding how solid waste is managed is a public policy matter. Protecting the public's interest is also a public policy matter. Local governments are in business to make public policy and protect the public interest. Such public policy decision making is not the role of private, for-profit companies. Local governments must never forget the fundamental principle that they are responsible for the management of MSW within their jurisdictions. It is not necessary that local governments own or operate a system. Competition and the "free market" will make that decision in the future. However, the "free market" place and true market pricing have nothing to do with the principle of local government responsibility.

There are many strategies for maintaining local control over solid waste management. These include owning and operating collection and disposal services; licensing private companies to provide solid waste management services (and requiring certain conditions as a prerequisite for receiving a license); contracting or franchising waste management services through competitive selection processes; and the creation of public-private partnerships for solid waste management. Contracts, franchise agreements, and partnership agreements can all be structured to include specific conditions necessary to protect the public's interest.

Harvey Alter (1995) offers his perspective on the loss of municipal control over solid waste management. According to him, local governments will always be able to protect the public health and the environment regardless of how much control they retain over day-to-day solid waste management decisions. He asks:

Why should a city want to manage [its] waste tightly if it's going to cost [the] citizens more money? Now what kind of public service is that? Cities still have responsibility for public health. They can use their police powers to assure that public health is maintained. They can license MSW management. Thus, they cannot lose total control. Besides, most of them have abrogated control of the nonhousehold portion of MSW already. So my view, my cynical view, is that it comes down to local politics. Political control is disappearing, but not the ability to take care of waste to protect public health and the environment.

\section{The Future of Federal Regulation}

Government regulation of solid waste management played a critical role in bringing solid waste management systems up to the standard we enjoy today. Even so, regulations promise far fewer benefits in the future. Regulations address only a small piece of what is a large and complex solid waste management system. They are a poor way to improve the whole system. Hickman (19951997) believes that the government's emphasis on regulation since the early 1970s is responsible for the demise of EPA's solid waste program as well as the current backlash against environmental regulation:

In the beginning, MSW was a nonregulatory program in a regulatory agency. EPA has always preferred to focus on regulation and enforcement. [It] never had a balanced program that focused both on regulation and on assistance to the regulated 
community to help [it] come into compliance. I believe the regulatory system should devote just as much effort to assisting the regulated community as to enforcement. All the research [EPA did] was to support [its] rules and regulations; [it has] funded very little basic research.

Regulation may be giving way to a new paradigm in which an enduring economic system values both the environment and industrial growth. In such a system, pollution prevention, waste minimization, and recycling would be orchestrated by a prosperous, environmentally conscious business community.

In a sense, the regulations sowed the seeds for this emerging "green" business community. A multibillion-dollar industry grew up to produce technologies to correct specific problems such as air and groundwater pollution. Regulated industries discovered that taking care of the environment made them more, not less, profitable. And American industry as a whole recognized that conserving materials and energy not only produced less waste, it also increased profit margins.

Even as industry recognized the benefits of protecting the environment, regulations began to create barriers to new growth. A good example exists within the waste-to-energy industry. In November 1995, the government issued additional restrictions on emissions of dioxin, a cancercausing chemical that has other deleterious health impacts. The regulation targeted emissions from waste-to-energy plants and ignored other dioxin sources. Walter (1994-1995) explains the fallacy of the reasoning behind such regulations:

Dioxin is a natural [substance]. [Nobel laureate] Bruce Ames says that you get more dioxin when you eat broccoli and cauliflower than you will ever get from a municipal waste plant or any manmade source. He says, ..."If God didn't mean for us to have dioxin in our bodies, He wouldn't have put receptors for it in our bodies."

The issue of dioxin is not the big bugaboo it's made out to be. If I stick my nose in a waste-to-energy plant stack for 70 years, I will get enough dioxin to give me one chance in a million to get cancer. Of course, I will have fried my head in less than an hour.

We still don't know how much dioxin coming out of a smokestack actually reaches the ground. The best we can do is to assume a worst case: A person is born, lives 70 years, works, and dies at a place with maximum exposure to dioxin. And, incidentally, the sun never shines there, because sunshine destroys dioxin. You know, if we look, there have been many serious accidents [when] dioxin [was used]. The worst one was in Italy where a pound of pure dioxin [blew] up the stack in an instant. Nobody died.

The waste-to-energy industry has reduced its dioxin emissions by more than 100 -fold since the early 1980s. As a result, municipal waste combustors contribute less than $3 \%$ of the total amount of dioxin emitted from known sources throughout the United States in a year. When implemented, the new regulation will reduce the waste-to-energy industry's contribution to about $1 \%$, according to H. Gregor Rigo (1995).

By narrowly focusing on dioxin emissions from the waste-to-energy industry, the regulation ignored the industry's ability to produce electricity with fewer emissions than coal, to reduce 
greenhouse gas emissions from landfills, to recover energy from waste, and to reduce the volume of solid waste by as much as $90 \%$.

The cost of complying with the regulation threatened to slow the growth of an industry that contributes significant overall environmental benefits. The potential benefit from the proposed regulation is only a small reduction in the amount of a single pollutant in the air. Because solid waste combustion will only be responsible for $1 \%$ of the dioxin added to the air, about $99 \%$ of the dioxin (contributed by other sources) will still be there.

Regulations like this have fostered an adversarial climate among industry, government, and nongovernmental organizations. Since 1985, different groups have tried to control an inflexible system that viewed environmental protection in black-and-white terms and, more often than not, stifled innovation. The antagonism undermined trust and reduced opportunities for experimentation and innovation. More workable and creative regulatory mechanisms would support the solid waste management industry in developing more environmentally sustainable methods and in participating in collaborative planning at the local, state, and federal levels.

The solid waste industry recognizes that environmental regulation may have reached the point of diminishing returns. But less regulation does not mean the solid waste industry plans to reject environmental principles that the American people hold dear. Rather, it means that environmental protection will remain part and parcel of the solid waste management business in America-because caring for the environment is good business.

\section{The Need for Research and Development}

Our current solid waste management methods need refinement to support environmentally sustainable economic development. Unfortunately, solid waste management professionals often cannot find the information they need to make better decisions about solid waste management. Too often, a strong opinion based on emotion, not on facts, is the deciding factor because objective information is not available. Vasuki (1996) explains why MSW research is crucial:

Not much is known about how landfills react. Even though the nation relies on landfills for managing $75 \%$ of its waste, Congress has appropriated no money for landfilling research in 10 years. I even suggested that we create a research fund on a voluntary basis by charging an extra $\$ 0.50$ per ton that would go into a national landfill research fund. This idea would generate about $\$ 90$ million a year. I wrote to the key folks in the Senate and the House. I got no response. I got no response from private industry. They said they'll do the research themselves. Local governments said there's no way they could pay more. I couldn't even get any interest from university professors.

In the past, federal MSW research focused on the development of one technology or on the solution to a specific problem rather than taking a systems approach to solid waste management. As a result, there are many holes in the basic information available about solid waste management technologies, according to Wiles (1995-1997):

Waste management professionals continually tell us they need credible information on the various methods used for MSW management. How do they perform? What are their costs? How do they affect the environment? How do you evaluate them? Since 
1994, we've been trying to answer these questions with a data collection and analysis project. $^{43}$

Public officials would like information on what is a reasonable technical approach to recycling and information on ash management. They'd like some credible information, assistance, and guidance because some regulatory positions and recent Supreme Court decisions don't make a whole lot of sense from a technical point of view.

What local solid waste professionals know is that there is no standard, across-theboard system for managing solid waste that works for everybody. In some respects, I think that's part of the problem with EPA over the years. It always addressed national types of issues rather than trying to get down to solving real problems on the local level.

Because of regulatory requirements, waste-to-energy combustion is the only technology that has been extensively tested. Other solid waste management methods, including collection, landfilling, composting, and recycling, have undergone far less scrutiny regarding their costs, efficiency, and environmental impacts. Even so, federal funding for applied research on new technologies has essentially vanished. Levy (1995) expects this to have a negative impact on the solid waste management industry in the future: "From a professional point of view, the whole industry is contracting. I think what's happening is that people are settling in on a fixed set of technologies, and they're not studying other alternatives. It's like a pendulum. It swings one way, then it swings back. They'll ignore solid waste for a while until the problems build up a head of steam; then they'll have to start all over again."

Before the federal MSW program was eliminated, SWANA worked with MSW program managers at NREL to define the applied research that would allow cities to provide the best possible solid waste management in the coming years. The research showed there is no single best management option, according to Hickman (1995-1997):

We had some money from DOE to compare various solid waste management methods on an economic and energy basis. We're learning some interesting things from it. We find that environmental emissions from the recycling trucks are only a minor factor. The major factor is collection costs. When you remove the added collection costs for recycling, there's not much cost difference between it and any of the other solid waste management options. They're all similar. A good landfill costs $\$ 25$ to $\$ 30$ a ton; a MRF costs $\$ 40$ to $\$ 50$ a ton; and an incinerator costs $\$ 50$ to $\$ 60$ a ton. That's not a lot of difference. The difference between $\$ 30$ and $\$ 60$ a ton is about $\$ 2.50$ a month for a family of four.

43 With the exception of completing the high-solids anaerobic-digestor pilot demonstration and preparation of a document on ash use, the data collection and analysis project, along with the rest DOE's MSW program, was terminated in 1997. 


\section{Federal Technology Research Projects}

The following research projects were completed after 1994 or were in progress when federal budget cuts eliminated the MSW research programs at EPA and DOE.

\section{Integrated Waste Management Case Studies}

NREL, SWANA, and the American Plastics Council completed a comprehensive study in 1995 of costs and energy use in six different integrated waste management systems. The systems were in Minneapolis, Minnesota; Palm Beach, Florida; Scottsdale, Arizona; Seattle, Washington; Sevierville, Tennessee; and Springfield, Massachusetts. Wiles (1995-1997) explains the objectives of the study:

People have been putting integrated waste management systems together for some time, and they don't understand the true cost and performance of various waste management methods within their system. For a long time, people have had no idea what solid waste management was costing them. Our goal was to work with SWANA to do a complete assessment of the components of representative waste management systems, then look at the system as a whole and see how well they were performing. We also wanted to see how one should go about evaluating various options. I wanted to produce a document that would tell local planners how to evaluate their options and put together an integrated waste management system.

The study developed a method for assessing the costs and benefits of separate components within an integrated solid waste management system. The method allows solid waste planners to better understand the real costs of particular services such as waste diversion. The study showed that it is not advisable to compare costs across systems, however. The wide range of possible services and differing local regulations made a valid comparison difficult.

The study offered the following insights:

- High costs do not necessarily mean a diversion or resource recovery program is not well designed and operated. (If collection and disposal costs are low, any diversion program will have relatively high costs, regardless of how efficient and well designed it is.)

- Collection is the most costly element of any integrated waste management system.

- Landfill costs are a relatively small part of system costs.

- The amount of energy used to collect and process recyclables and yard waste is relatively small.

- Many fixed costs for landfilling will remain even if solid waste is diverted to another program.

\section{Materials Recovery Facilities}

EPA and NREL co-sponsored a study completed in 1995 of the environmental, economic, and energy impacts of six different MRFs throughout the United States. The facilities were located in Islip, New York; Montgomery County, Maryland; Albuquerque, New Mexico; Hartford, Connecticut; Rice County, Minnesota; and Orange County, Florida. The facilities receive both commingled and source-separated wastes. They employ a variety of techniques to recover usable 
materials. Wiles (1995-1997) comments on the study: "Unfortunately, the MRF study concentrated more on the environmental aspects than it did on the cost and energy implications of materials recovery and recycling. You need to do all of it. Nevertheless, the study provides good information on how six different MRFs are performing." The study focused on air pollution, water pollution, and noise in addition to such occupational health and safety issues as exposure to chemicals and germs, safety hazards, and ergonomic stressors. It concluded that MRFs do not pose a significant threat to public health or the environment if operated according to standard practices for protecting workers and the environment.

Although it did not evaluate energy and economic impacts in detail, the study concluded that MRFs are expensive. Costs of operation consistently outweigh revenues from the sale of recovered materials. Energy consumption is also higher for materials recovery than it is for disposal methods such as waste combustion or landfilling. Collection was responsible for most of the increased cost and energy use. The study focused solely on MRFs and did not look at the energy, cost, and environmental impacts of transporting recovered materials to a remanufacturing facility and solid waste to a disposal site.

\section{Comprehensive Model of Integrated Solid Waste Management}

Information gathering and analysis is potentially one of the most valuable functions that could be performed by a national MSW program. Detailed information about the amount and composition of solid waste generated by more than 35,000 communities throughout the United States would be an invaluable resource to communities if such information were readily available through a centralized database. The database could also include detailed statistics regarding MSW management in those same communities. Once data were collected, a computer model for integrated waste management could be developed.

In 1994, EPA and DOE began planning a joint project to develop such a database on recycling, composting, MSW combustion, and landfilling. Researchers planned to evaluate management options for paper, glass, metals, and plastics in terms of their materials and energy requirements, environmental impacts, and costs. The analysis was to cover the entire life cycle, from the acquisition of raw materials through manufacturing, use, reuse, and waste management.

The agencies planned to assemble a database on emissions, resource and energy consumption, and representative costs of all operations involved in solid waste management. They also planned to gather data on obtaining raw materials, manufacturing (and remanufacturing), consumer use, reuse, and waste generation patterns. In a similar effort to understand public works from a systems perspective, APWA planned a detailed cost study in 1996 of municipal services, including waste management.

If completed, the studies would have allowed communities across the nation to compare goals, community characteristics, economic constraints, waste management methods, costs, and systems. Solid waste professionals could provide data about the quantity and type of local waste, available resources and technologies, current management methods, proposed management methods, and so forth. The model would allow communities to mix and match management strategies to determine the best combination for their particular situations. It would also help them to find solutions for specific solid waste management problems. Wiles (1995-1997) explains:

If I were given a big budget, I would use it to go out there and help people figure out what makes sense for their particular situation. Should they recycle this component or is it better to throw it into a waste-to-energy facility? You know it's easy to say 
you should recycle everything, but you can't. The public has been led down that path by environmental groups that oppose combustion. They don't like landfilling, so they come down to waste reduction and recycling, but you can't manage all your waste that way.

At least give people the data. Maybe they'll find out that recycling certain things costs more, but they'll choose to do it anyway. I read in the paper that people love to recycle because it makes them feel involved. And, I look at that word "love" and think that love is induced in people who don't understand the implications of what they're doing.

\section{Argonne Studies}

In 1997, Argonne National Laboratory concluded more than 20 years of research on RDFs and landfills. The studies included the distribution of gases inside landfills, landfill emissions, the processing of organic waste inside a landfill, and better methods for RDF production and combustion.

\section{Research Projects Requested by Industry}

Although the federal government had no mechanism for supporting new solid waste research projects after 1996, SWANA developed a wish list of projects the organization would have liked the federal government to undertake to improve MSW management technologies and methods. The proposed projects included:

\section{- A comprehensive handbook of MSW management-}

The handbook would describe the best technologies and methods for collecting solid waste; building and operating transfer stations, materials recycling facilities, and wasteto-energy facilities; recycling; managing yard waste; composting; and landfilling. The handbook would give information about contracting with industry for MSW management and take account of variations in state and local laws, customs, climate, and population.

- A study comparing the environmental impacts of waste combustion and landfilling-

The study would compare air and water emissions from landfills and waste-to-energy plants.

- A study to determine the best way to measure emissions of non-methane organic compounds from landfills-

A good method for measuring non-methane organic compounds should be an essential component of state and local programs to comply with EPA's new air-emissions standards for landfills. There is currently no proven technique for measuring landfill emissions. 
- A study of the impact of state and local fees on integrated solid waste management-

A comprehensive analysis of MSW management costs and fees is needed to determine the costs and benefits of specific waste management options. The myriad ways cities currently deal with costs can result in hidden federal subsidies, hidden costs, and a number of other, often unrecognized, inequities and problems.

- An analysis of state enforcement of EPA regulations governing solid waste combustion and landfilling-

This study would evaluate the willingness and ability of all 50 states to enforce current MSW regulations.

- An analysis of automated collection for yard trimmings-

This short review of the costs and benefits of using automated collection systems for grass clippings and other yard wastes would be particularly useful for cities that compost this waste.

\section{- A manual of collection fleet management}

Waste management professionals need a manual that covers collection fleet operation, maintenance, and inventory procedures. The manual would assist workers in keeping equipment running, tracking costs, and identifying needs for new equipment.

\section{- A study of household hazardous waste management-}

Despite a large number of special collection and management programs across the nation for household hazardous waste, there is much confusion regarding the care with which particular substances should be handled. The study would provide detailed information about recycling or safely disposing of specific household hazardous waste. The study would include tips on how to reduce program costs.

\section{- An analysis of variable-rate collection systems-}

The study would assess the effectiveness of variable-rate collection systems for diverting solid waste and meeting revenue needs. It would provide information regarding types of fees and needs for specialized equipment. 


\section{- Privatization case studies-}

A set of case studies would be assembled to help local solid waste authorities understand the steps needed to ensure effective privatization of collection services incorporating necessary local controls.

Hickman would like the federal government to sponsor this research because federal agencies are uniquely suited to sponsor comprehensive studies impacting tens of thousands of U.S. cities. He explains (1995-1997):

DOE and EPA have contributed to the improvement of the major methodologies, and that's the kind of work we encourage. Let's find ways to better understand and improve on the things we have, so we can make them more efficient, cost-effective, and environmentally sound. For example, we'd like to know the answers to: How can we optimize collection routes? How can we use less fuel when delivering solid waste to a landfill or incinerator and recyclables to a MRF? How can we get more energy more efficiently out of landfills? In short, we'd like a better understanding of what the hell it is we do.

The problem is there's not enough money for solid waste research anymore. It's basically gone. There's no commitment, no federal focus like there was during the 1960s and early 1970s. There's a little private research, but that's done for the purpose of some company, and it's not readily available.

\section{The Benefits of a Federal Role in Solid Waste Management}

During the coming decades, the nation must use energy and materials more efficiently to produce goods and services and curb excessive solid waste generation. Solid waste management systems that emphasize the recycling of materials and production of energy will play a significant role - provided innovative, low-cost solid waste management technologies become available. How to accomplish this is a matter of some debate.

Government regulation can drive innovation, but the resulting technologies are often very expensive. All too often, innovation grinds to a halt once regulatory standards are met. Alternatively, private industry can take responsibility for developing new, cost-effective technologies - with or without regulatory incentives. This strategy works well for technologies near commercialization.

Long-term technology development is a high-risk proposition for industry, however. Few, if any, companies can afford to undertake the development of next- generation technologies, which do not pay off commercially for many years. Nevertheless, the nation's future competitiveness depends on such efforts. So does environmentally sustainable development.

Public-private partnerships can be excellent devices for fostering the development of nextgeneration technologies. By working together, the public and private sectors can enhance solid waste management systems, analytical methods, databases, and information systems needed by communities to meet tomorrow's challenges.

The federal government has played a role in solid waste management for more than 30 years. New legislation, regulation, research, and development all helped improve modern solid waste management methods. Thus far, the nation has not set national goals with respect to solid waste management; and the government has not developed and implemented a comprehensive national 
policy for MSW. Rather, the United States has relied upon short-term goals and objectives reflecting day-to-day political concerns to mold its solid waste programs. Long-range, strategic planning has been almost nonexistent.

In the mid-1960s, there was consensus that the federal government had an important role to play in improving solid waste management. The following decade saw several key laws enacted that defined a federal role in improving solid waste disposal technologies and in encouraging the recovery of materials and energy. By the late 1970s, a modest federal solid waste program focused its efforts on resource recovery, the marketability of recovered materials, institutional barriers to recycling, inequities in government incentives for resource recovery and recycling, the desirability of source separation, and the feasibility of waste-to-energy conversion. Even so, concerns about solid waste took a back seat to fears about hazardous waste.

By the late 1980s, government regulations had closed down open dumps and the worst polluting incinerators and landfills. The goals for the government's solid waste program, however, had changed very little. Resource recovery was still seen as the key ingredient in a modern solid waste management system. Most of the goals of the federal program in the 1970s were still in place. Technologies for recovering energy and materials from solid waste changed. The most important new development in the late 1980s was the recognition that waste minimization would be necessary to curb ever-increasing amounts of solid waste.

The perception of a garbage crisis in 1987 rekindled discussion of an expanded federal role in solid waste management. An Office of Technology Assessment report outlined short-term objectives for this role (Levinson 1989). The objectives included establishing a national solid waste database, providing recycling incentives, continuing solid waste technology research and development, providing technical assistance to states, establishing packaging and product regulations to reduce the amount and toxicity of waste, developing procurement standards for recycled products, and finalizing regulations for solid waste combustion and landfilling.

The recommendations did not include the development of long-term goals for solid waste management as part of a national policy on solid waste. The lack of long-term national goals fostered the illusion that solid waste was no longer a problem, at least at the national level. Without a crisis to stir up public concerns, federal agencies turned their attention away from solid waste research. A long-standing commitment to state and local authority over solid waste management made the federal program vulnerable to budget-cutting.

During the early 1990s, solid waste technology development continued, a number of federal agencies established procurement standards for recycled materials, and EPA finalized combustion and landfilling regulations. However, there were troubling developments as well. Political support for recycling incentives and packaging and product regulations declined. In 1993, EPA ended its solid waste research program for the second time in less than 15 years. DOE eliminated the MSW research program from its 1997 budget request.

Several factors contributed to this situation. Many objectives for the original federal program had been accomplished or discarded. The benefit of continuing some environmental regulations was called into question both by members of Congress and the Clinton administration. And government agencies faced significant budget cuts as a result of Congress's desire to reduce deficit spending.

What are the ramifications of ending the federal MSW program? Without a federal solid waste program, the nation will continue to rely primarily on landfills for solid waste disposal. Substantial amounts of energy will be buried each day along with materials that could have been recycled. Emissions of greenhouse gases will continue unabated from many sites. 
States, local governments, and the private sector often support the development of new solid waste technologies when federal funding is available. Otherwise, research tends to fall by the wayside. Similarly, local governments, private companies, and state agencies often lack incentives or resources to gather and analyze the detailed solid waste information required to maintain healthy communities.

The federal government has a role to play in assisting decision makers in making good solid waste management decisions for their communities, in helping industry understand its role in solid waste generation and management, and in developing solid waste as an energy resource. Wiles (1995-1997) explains:

MSW is a unique program. It doesn't fit into a neat little niche because it isn't one, clearly identifiable industry. But every industry has a large stake in the MSW area. They all need to be concerned about how they manufacture products and how their products will affect the MSW stream. Looked at from the back end, MSW affects all industries. It should be organized as such.

Right now, industry planners don't consider MSW when they develop visions of the future because they don't understand how MSW fits into the larger scheme of things. That's something a federal effort could have helped them with. Unfortunately, MSW just doesn't have a lot of sex appeal. I wish we could have overcome that.

Government agencies are uniquely qualified to support research, develop better management technologies, collect and analyze information, evaluate new technologies and management systems, disseminate information, and provide technical assistance in implementing new management methods. These roles are not ones local governments can be expected to assume. Their job is day-today management of solid waste. Local governments do not have the resources to develop better solid waste management methods for the future. Without access to educational publications, solid waste conferences, technical training programs, and a detailed information database, more than 35,000 local communities will have to go it alone. This situation may not be in their best interests, and it will not be beneficial for the nation as a whole.

Ideally, advances in solid waste management systems should come out of a broad scientific and technical understanding of the environment rather than from a simple response to regulations. There is much to be gained from in-depth analyses of the role of solid waste generation in maintaining a healthy economy and from collaboration on solid waste management at the local, state, and national levels. The solid waste management field and federal, state, and local governments all have roles to play in developing improved solid waste management technologies and methods for the twenty-first century. The sooner we realize this, the better. 


\section{Bibliography}

AIMS Coalition (1994). Waste-to-Energy: Making a Clean Energy Source Cleaner. Coalition of the Solid Waste Processing Division of the Council on Engineering of the American Society of Mechanical Engineers, the Integrated Waste Services Association, the Municipal Waste Management Association of the U.S. Conference of Mayors, and the Solid Waste Association of North America.

Alexander, J.H. (1995). The State of Garbage. Proceedings of the U.S./Canadian Federation Solid Waste Management Conference in Washington, D.C., January 17-20, pp. 13-16.

Alexander, J.H. (1993). In Defense of Garbage. Westport, Connecticut, and London: Praeger.

Alter, H. (1995). U.S. Chamber of Commerce, Washington, D.C.: personal communication.

Alter, H. (1987). The History of Refuse-Derived Fuels. Resources and Conservation, Vol. 15, pp. 251-275.

American Public Works Association (APWA) (1976). History of Public Works in the United States, 1776-1976, Armstrong, E.L., Robinson, M.C., and Hoy, S.M., eds. Chicago: American Public Works Association.

American Public Works Association (1989). Public Works Today: A Profile of Local Service Organizations and Managers. APWA Special Report No. 57. Chicago: American Public Works Association.

Anderson, R. (1995). Wheelabrator Environmental Systems, Inc., Washington, D.C.: personal communication.

Arbuckle, J.G., et al. (1991). Environmental Law Handbook. Rockville, Maryland: Government Institutes, Inc.

Bender, M. (1997). Almost Half of the Northeast's Landfills Lack Lining Systems. Waste Dynamics Northeast, Vol. 8, No. 11, Mar. 1997.

Beyea, J. (1995). A Vision for Composting. Proceedings of the 6th Annual Waste Reduction, Prevention, Recycling, and Composting Symposium in Denver, Colorado, Feb. 27-Mar. 1, pp. 48-54.

Beyea, J. (1995). Chief Scientist and Vice President, National Audubon Society: personal communication.

Black, R.J.; Muhich, A.J.; Klee, A.J.; Hickman, H.L., Jr.; and Vaughan, R.D. (1968). The National Solid Waste Survey: An Interim Report. Cincinnati, Ohio: U.S. Department of Health, Education, and Welfare.

Blumberg, L. and Gottlieb, R. (1989). War on Waste. Covelo, California: Island Press. 
Bogner, J. (1995). Argonne National Laboratory, Argonne, Illinois: personal communication.

Bogner, J. and Spokas, K. (1993). Landfill $\mathrm{CH}_{4}$ : Rates, Fates, and Role in Global Carbon Cycle. Chemosphere, Vol. 26, No. 1-4, pp. 369-386.

Bogner, J.; Spokas, K.; and Jolas, J. (1993). Comparison of Measured and Calculated Methane Emissions at Mallard Lake Landfill, Dupage County, Illinois, U.S.A. Proceedings of the International Landfill Symposium in S. Margherita di Pula, Italy, October 1993.

Bogner, J.E. (1992). Anaerobic Burial of Refuse in Landfills: Increased Atmospheric Methane and Implications for Increased Carbon Storage. Ecological Bulletins, Vol. 42, pp. 98-108, Copenhagen.

Bogner, J.E. (1990). Controlled Study of Landfill Biodegradation Rates Using Modified BMP Assays. Waste Management \& Research, Vol. 8, pp. 329-352.

Bubenick, D. (1995). Higate Associates, Chelmsford, Massachusetts: personal communication.

Bull, S. (1995). National Renewable Energy Laboratory, Golden, Colorado: personal communication.

California Energy Commission (1991). Energy Technology Status Report. Appendix A, Volume I: Detailed Electric Generation Technology Evaluations. Sacramento, California.

Christensen, T.H., et al. (1989). Sanitary Landfilling: Process, Technology and Environmental Impact. San Diego: Academic Press, Inc.

Cobb, C.E. and Ruckstuhl, K. (1988). Mining and Reclaiming Existing Sanitary Landfills. Proceedings of the ASME National Waste Processing Conference in Philadelphia, Pennsylvania.

Collins, J. (1995). Former branch chief, Industrial Waste Utilization, U.S. Department of Energy: personal communication.

Crawford, G. (1996). Steel Recycling Institute, Pittsburgh, Pennsylvania: personal communication.

Curling, D. (1995). Southeastern Public Service Authority, Chesapeake, Virginia: personal communication.

DeCeasare, R. (1995). Bureau of Mines, Washington, D.C.: personal communication.

DeGeare, T. (1995). Environmental Protection Agency Office of Solid Waste, Washington, D.C.: personal communication.

Denison, R. (1995). Environmental Defense Fund, Washington, D.C.: personal communication.

Easterbrook, G. (1995). A Moment on the Earth. New York: Viking Penguin. 
"The End of the Beginning" (Apr./May 1995). Environmental Business Journal, Vol. 8, No. 4-5, pp. 1-13.

Engel, P. and Croteau, G. (March 1995). Proceedings of the 6th Annual Waste Reduction, Prevention, Recycling, and Composting Symposium in Denver, Colorado, Feb. 27-Mar. 1, pp. $36-46$.

Fehner, T.R. and Holl, J.M. (1994). The United States Department of Energy, 1977-1994: A Summary History, Energy History Series, History Division, U.S. DOE: Available from Office of Scientific and Technical Information, POB 62, Oak Ridge, TN 37831.

Friedrich, S. (1995-1997). U.S. Department of Energy, Washington, D.C.: personal communication.

Friedrich, S. (1995). Plenary session, U.S./Canadian Federation Solid Waste Management Conference in Washington, D. C., Jan. 17-20.

Frola, C. (1995). Solid Waste Association of North America, Silver Spring, Maryland: personal communication.

Gaines, L.L. and Stodolsky, F. (1993). Mandated Recycling Rates: Impacts on Energy Consumption and Municipal Solid Waste Volume. Argonne National Laboratory: Available from the National Technical Information Service, U.S. Department of Commerce, 5285 Port Royal Road, Springfield, VA 22161.

Ganotis, C. (1995). Wheelabrator Environmental Systems, Inc., Hampton, New Hampshire: personal communication.

Gendegren, A., et al. (1992). Landfill Gas: From Environment to Energy. Luxembourg: CEC, Directorate-General Telecommunications, Information Industries and Innovation.

Goodman, B. (1995). National Renewable Energy Laboratory, Golden, Colorado: personal communication.

Greenberg, F.L. (1996). Attorney, Evanston, Illinois: personal communication.

Gunter, M. (1995). U.S. Department of Energy, Washington, D.C.: personal communication.

Gupta, B. (1996). National Renewable Energy Laboratory, Golden, Colorado: personal communication.

Handbook of Solid Waste Management (1994). Kreith, K., editor in chief. New York: McGraw-Hill, Inc.

Hartman, M. (1996). Formerly of Combustion Engineering: personal communication. 
Heenan, W.M., Jr. (1996). “The Inherent Recycled Content of Today's Steel." Pittsburgh, Pennsylvania: Steel Recycling Institute.

Helt, J. (1995). Argonne National Laboratory, Argonne, Illinois: personal communication.

Hershkowitz, A. (1995). National Resources Defense Council, Washington, D.C.: personal communication.

Hickman, H.L., Jr. (1995-1997). Solid Waste Association of North America, Silver Spring, Maryland: personal communication.

Hickman, H.L., Jr. (Jan./Apr. 1996). Editorials, in MSW Solutions, The Newsletter of the Solid Waste Association of North America, Silver Spring, Maryland.

Hollander, H.I. (1995). Professional Engineer, Wyamissing, Pennsylvania: personal communication.

Hummel, J., White, P. R., and Willmore, J. (1996). Affordable Recycling-the Critical Factors. Brussels, Belgium: European Recovery \& Recycling Association.

Integrated Waste Services Association (IWSA). (1994). Managing America's Trash: The Integrated Approach. Washington, D.C.: IWSA.

Intergovernmental Panel on Climate Change. (1990). Climate Change: The IPCC Scientific Assessment, 1990. J.T. Houghton, G.J. Jenkins, and J.J. Ephraums, editors. Cambridge, England: Cambridge University Press.

Jones, K.H. (March/April 1994). "Comparing Air Emissions from Landfills and Waste-to-Energy Plants,” Solid Waste Technologies, Vol. VIII, No. 2, pp. 28-39.

Kehoe, J. (1995). Wheelabrator Environmental Systems, Inc. Hampton, New Hampshire: personal communication.

Kilgroe, James D. (1996). Senior Project Manager, USEPA: personal communication.

Kirk-Othmer Encyclopedia of Chemical Technology (1991). Executive editor, Kroschwitz, J.I., Editor, Howe-Grant, M. Fourth edition, Vol. 4, New York: John Wiley \& Sons.

Kiser, J.V.L. (1995a). The 1995 IWSA Municipal Waste Combustion Directory of United States Facilities. Washington, D.C.: Integrated Waste Services Association.

Kiser, J.V.L. (1995b). Integrated Waste Services Association, Washington, D.C.: personal communication.

Kiser, J.V.L. (June 1993). Putting the Pieces Together: Integrated Waste Management. American City \& Country, pp. 26-36: Communications Channels, Inc. 
Kiser, J.V.L. (1992). Recycling and WTE: Working Well Together. Solid Waste \& Power/Industry Sourcebook, 1993. Kansas City, Missouri: HCI Publications, Inc.

Kreith, F. (October 1992). Garbage, Garbage, Garbage. State Legislatures, pp. 24-26. Denver, Colorado: National Conference of State Legislatures.

Lambert, R. (1996). Economist, Tennessee Valley Authority: personal communication.

Landreth, R. (1995). U.S. Environmental Protection Agency (retired), Cincinnati, Ohio: personal communication.

Lazar, J. (1995). Former MSW Program Manager, Argonne National Laboratory, Argonne, Illinois: personal communication.

Leighton, J. (1995). Formerly with the U.S. Department of Energy, Washington, D.C.: personal communication.

Levinson, H., et al. (1989). Facing America's Trash. Washington, D.C.: Congress of the United States, Office of Technology Assessment: OTA-O-424.

Levy, S. (1995). U.S. Environmental Protection Agency Office of Solid Waste, Washington, D.C.: personal communication.

Loose, R. (1995). U.S. Department of Energy, Washington, D.C.: personal communication.

Melosi, M.V. (1981a). Garbage in the Cities. College Station: Texas A\&M University Press..

Melosi, M.V. (October 1981b). Waste Management: The Cleaning of America. Environment. Vol. 23, No. 8, pp. 6-13.

Merritt, J. (1995). Waste-to-Energy: What Are the Issues? Proceedings of the U.S./Canadian Federation Solid Waste Management Conference in Washington, D. C., Jan. 17-20, pp. 146-151.

Mutch, R.D., Jr. (1995). The History of Land-Based Disposal in the U.S.: What It Tells Us. Proceedings of the U.S./Canadian Federation Solid Waste Management Conference in Washington, D.C., Jan. 17-20, pp. 61-72.

National Renewable Energy Laboratory (1992). Data Summary of Municipal Solid Waste Management Alternatives: NREL/TP-431-4988.

National Renewable Energy Laboratory (1995). Integrated Municipal Solid Waste Management: Six Case Studies of System Cost and Energy Use: NREL/TP-430-20471.

National Science and Technology Council (Apr. 1995). Bridge to a Sustainable Future. Available from the Interagency Environmental Technologies Office, 955 L'Enfant Plaza North, SW, Suite 5322, Washington, D.C. 20024 or via Internet: etstrategy@gnet.org. 
Natof, S. (1995). U.S. Department of Energy, Washington, D.C.: personal communication.

Ohlsson, O. (1995). Argonne National Laboratory, Argonne, Illinois: personal communication.

Philippidis, G. (1995). National Renewable Energy Laboratory, Golden, Colorado: personal communication.

Porter, J.W. (1995). Porter \& Associates, Sterling, Virginia: personal communication.

Potential of Renewable Energy: An Interlaboratory White Paper. (1990). Prepared for the Office of Policy, Planning and Analysis, U.S. DOE, SERI/TP-260-3674.

Rathje, W. and Cullen, M. (1992). RUBBISH! The Archaeology of Garbage. New York: Harper Perennial.

Rathje, W. (May 1991). "Once and Future Landfills," National Geographic. Vol. 179, No. 5, pp. 116-134.

Rathje, W.E. (Sept./Oct. 1990). The History of Garbage: Archaeologists Bust Myths about Solid Waste and Society. Garbage Magazine. Vol. 5, pp. 32-41.

Rigo, H.G. (Jan./Feb. 1995). Sources of Dioxin in the Environment. Solid Waste Technologies. Vol. XIX, pp. 36-39.

Rivard, C. (1995). National Renewable Energy Laboratory, Golden, Colorado: personal communication.

Shepherd, P. (1995). National Renewable Energy Laboratory, Golden, Colorado: personal communication.

Sjorberg, T. (1995). Retired, Tampa, Florida: personal communication.

Skinner, J. (Jan. 1995). International Progress in Solid Waste Management. Proceedings of the U.S./Canadian Federation Solid Waste Management Conference in Washington, D. C., January 1720, pp. $1-12$.

Smith, G. (1995). Ogden Martin Systems, Inc., Fairfield, New Jersey: personal communication.

SRI International (August 1992). Data Summary of Municipal Solid Waste Management Alternatives. National Renewable Energy Laboratory: NREL/TP-431-4988 • UC Category: 249 • DE92016433.

Steuteville, R. (Apr./May 1995). "The State of Garbage in America, Parts I \& II. Biocycle, pp. 54-63.

Stoldowski, F. (1995). Argonne National Laboratory, Washington, D.C.: personal communication. 
Streb, A. (1995). U.S. Department of Energy, Washington, D.C.: personal communication.

Sussman, D. (1995). Ogden Martin Systems, Inc., Arlington, Virginia: personal communication.

Sutherland, G.D. of R.W. Beck (1995). Recycled Market Materials History and Index. Proceedings of the 6th Annual Waste Reduction, Prevention, Recycling, and Composting Symposium in Denver, Colorado, Feb. 27-Mar. 1, pp. 76-96.

Tardy, R.J. (March 1995). Operating Guidelines for Municipal Mixed Organics Composting Facilities. Proceedings of the 6th Annual Waste Reduction, Prevention, Recycling, and Composting Symposium in Denver, Colorado, Feb. 27-Mar. 1, pp. 56-67.

Taylor, A. and Zannes, M. (May 1996). The 1996 IWSA Municipal Waste Combustion Directory of United States Facilities. Washington D.C.: Integrated Waste Services Association.

Thorneloe, S. (1995-1996). U.S. Environmental Protection Agency, Research Triangle Park, North Carolina: personal communication.

Thorneloe, S.A. and Pacey, J.G. (1994). Landfill Gas Utilitization-Database of North American Projects. Proceedings of the Annual International Landfill Gas Symposium in Long Beach, California, March 22-24.

Thorneloe, S.A., (1993). Landfill Gas and Its Influence on Global Climate Change. Landfilling of Waste: Gas. Washington, D. C.: U. S. Environmental Protection Agency.

Thorneloe, S.A. (Mar. 1992a). Landfill Gas Recovery/Utilization-Options and Economics. Proceedings of the Sixteenth Annual Conference on Energy from Biomass and Wastes held in Orlando, Florida.

Thorneloe, S.A. (August 1992b). Emissions and Mitigation at Landfills and Other Waste Management Facilities. Proceedings of the EPA Symposium on Greenhouse Gas Emissions and Mitigation Research held in Washington, D.C.

Trezak, G. (1995). BKK Corporation, Long Beach, California: personal communication.

Tyler, P. (1994). The Problems of Landfilling Municipal Solid Waste: An Annotated Bibliography. Clemson, South Carolina: Robert M. Cooper Library, Clemson University.

Uehling, M. (August 1993). Keeping Rubbish Rotten to the Core. New Scientist, pp. 12-13.

U.S. Environmental Protection Agency (1971). Sanitary Landfill Facts. Publication No. 1972. Washington, D. C.: U.S. Public Health Service.

Vasuki, N.C. (1996). CEO, Delaware Solid Waste Authority: personal communication.

Velzey, C.R. (1995). Charles R. Velzey, Inc., Lyndonville, Vermont: personal communication. 
Walter, D.K. (1994-1995). U.S. Department of Energy (retired), Severna Park, Maryland: personal communication.

Weddle, B. (1995). U.S. Environmental Protection Agency, Washington, D.C.: personal communication.

Wiles, C. (1995-1997). National Renewable Energy Laboratory, Golden, Colorado: personal communication.

Wong, J. and Edwards, H.W. (Mar. 1995). Waste Prevention Saves Money: Industry Case Studies. Proceedings of the 6th Annual Waste Reduction, Prevention, Recycling, and Composting Symposium in Denver, Colorado, Feb. 27-Mar. 1, pp. 10-16. 


\section{Abbreviations and Acronyms}

\begin{tabular}{ll} 
AEC & Atomic Energy Commission \\
APWA & American Public Works Association \\
ASME & American Society of Mechanical Engineers \\
Btu & British thermal unit \\
CERCLA & Comprehensive Environmental Response, Compensation and Liability Act \\
cm & centimeter \\
D.C. & District of Columbia \\
DOE & U. S. Department of Energy \\
EPAct & Energy Policy Act \\
EPA & U. S. Environmental Protection Agency \\
EPRI & Electric Power Research Institute \\
ERDA & Energy Research and Development Administration \\
FAA & Federal Aviation Administration \\
HDPE & high-density polyethylene \\
HEW & Department of Health, Education, and Welfare \\
HSWA & Hazardous and solid waste amendments (to RCRA) \\
GE & General Electric \\
GRCDA & Governmental Refuse Collection and Disposal Association \\
KAB & Keep America Beautiful, Inc. \\
kWh & kilowatt-hour \\
MACT & maximum achievable control technology \\
mm & millimeter \\
MRF & materials recovery facility \\
MSW & municipal solid waste \\
MW & megawatt \\
NCRR & National Center for Resource Recovery \\
NEPA & National Environmental Policy Act \\
NIMBY & not-in-my-backyard \\
NO & nitrogen oxides \\
NRC & Nuclear Regulatory Commission \\
NREL & National Renewable Energy Laboratory \\
PET & polyethylene terphthalate \\
PVC & polyvinyl chloride \\
PURPA & Public Utility Regulatory Policies Act \\
RCRA & Resource Conservation and Recovery Act \\
R\&D & research and development \\
RANN & research applied to national needs \\
RDF & refuse-derived fuel \\
d-RDF & densified refuse-derived fuel \\
SERI & Solar Energy Research Institute \\
SWANA & Solid Waste Association of North America \\
TVA & Tennessee Valley Authority \\
& \\
\hline
\end{tabular}




\section{Credits}

The following individuals gave generously of their time, experience, and insights in the preparation of this book.

\section{Project Director: \\ Helena Li Chum \\ Interviewers: \\ Julie Ann Phillips \\ Rick Piltz}

Technical Assistance:

Philip Shepherd

Carlton Wiles

\section{Writer:}

Julie Ann Phillips

\section{Editors:}

Mary Margaret Coates

Gary Cook

Alice Levine

\section{Reviewers:}

Harvey Alter

Helena Li Chum

Simon Friedrich

H. Lanier Hickman, Jr.

Steve Levy

Philip Shepherd

N.C. Vasuki

Donald K. Walter

Carlton Wiles

Maria Zannes 


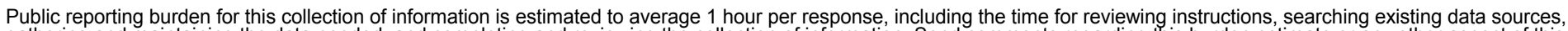

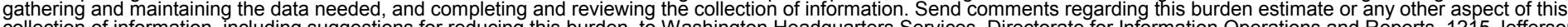
Davis Highway, Suite 1204, Arlington, VA 22202-4302, and to the Office of Management and Budget, Paperwork Reduction Project (0704-0188), Washington, DC 20503.
1. AGENCY USE ONLY (Leave blank)
2. REPORT DATE
3. REPORT TYPE AND DATES COVERED
September 1998
NREL Subcontract Report

4. TITLE AND SUBTITLE

Managing America's Solid Waste

6. $\operatorname{AUTHOR}(\mathrm{S})$

J.A. Phillips

7. PERFORMING ORGANIZATION NAME(S) AND ADDRESS(ES)

J.A. Phillips \& Associates

Boulder, Colorado

9. SPONSORING/MONITORING AGENCY NAME(S) AND ADDRESS(ES)

National Renewable Energy Laboratory

1617 Cole Blvd.

Golden, CO 80401-3393

5. FUNDING NUMBERS

C: AAE-5-14269

Task \#: IT631010

8. PERFORMING ORGANIZATION REPORT NUMBER

11. SUPPLEMENTARY NOTES

NREL Technical Monitor: Carlton Wiles

12a. DISTRIBUTION/AVAILABILITY STATEMENT

National Technical Information Service

12b. DISTRIBUTION CODE

U.S. Department of Commerce

5285 Port Royal Road

Springfield, VA 22161

13. ABSTRACT (Maximum 200 words) Solid waste management has changed in important ways during the past 30 years. Across the nation, modern, well-designed landfills and waste-to-energy plants have replaced open dumps and polluting incinerators. Recycling has become an integral part of solid waste management in most communities. The nation as a whole is committed to safer, more environmentally responsible management of solid waste.

14. SUBJECT TERMS

municipal solid waste (MSW) ; landfill ; recycling

15. NUMBER OF PAGES

16. PRICE CODE

17. SECURITY CLASSIFICATION

OF REPORT

Unclassified

18. SECURITY CLASSIFICATION OF THIS PAGE Unclassified
19. SECURITY CLASSIFICATION OF ABSTRACT

Unclassified
20. LIMITATION OF ABSTRACT

UL 